UNIVERSIDADE DE SÃO PAULO

INSTITUTO DE GEOCIÊNCIAS

\title{
AVALIAÇÃO DE MÉTODOS GEOFíSICOS NO COMPORTAMENTO ESPACIAL DE PLUMAS DE NECROCHORUME
}

Fernando Augusto Saraiva

Orientador: Prof. Dr. Fabio Taioli

TESE DE DOUTORAMENTO

Programa de Pós-Graduação em Recursos Minerais e Hidrogeologia

SÃO PAULO

2010 
Ficha catalográfica preparada pelo Serviço de Biblioteca e Documentação do Instituto de Geociências da Universidade de São Paulo

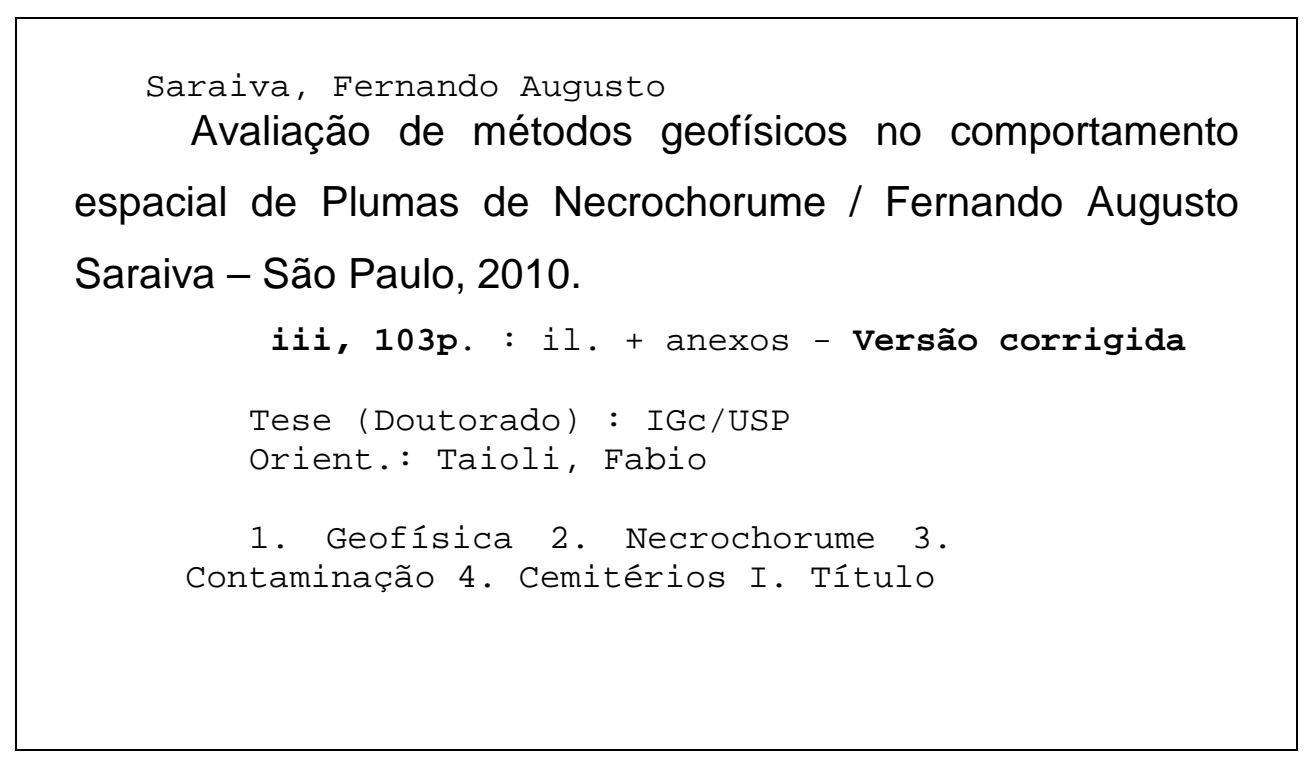


À Ana Cristina, João Pedro e Ana Clara que são, juntos, o sentido de minha vida. 
Agradecimentos

Ao meu orientador Fabio Taioli, que acolheu a idéia, apoiou em todas as fases e me permitiu liberdade na pesquisa.

À FAPESP, pelo financiamento do Projeto de Pesquisa (Processo 2006/06755-0), sem o qual este trabalho não teria sido possível.

Ao Prof. José D.F. Gallas pelo companheirismo típico dos gaúchos, almoços e pela ajuda ímpar no tratamento dos dados.

Ao Prof. Adolfo José Melfi na escolha da área e apoio na descrição do solo/geologia.

Aos Profs. da FZEA/USP Holmer Savastano Junior, Douglas Emygdio de Faria e Marcelo Machado De Luca de Oliveira Ribeiro pelo empréstimo da área e apoio logístico.

Ao Prof. Carlos Augusto Fernandes de Oliveira e à técnica Royce do Laboratório de Microbiologia e Micotoxicologia de Alimentos da FZEA pelas análises microbiológicas.

Aos funcionários do Campus USP de Pirassununga, em especial da Coordenadoria do Campus pelo apoio logístico, da Zeladoria pela infra-estrutura das residências e Matadouro-escola pelo material necessário para a pesquisa e amizade.

Ao Prof. Vicente A.V. Girardi pela ajuda na descrição das lâminas e geologia.

Aos colegas do IGc: Veridiana, Renato, Hachiro e Gustavo pelas conversas diárias, tendo ou não a ver com este trabalho.

Aos geofísicos Octavio Coaracy Brasil Gandolfo e Douglas Bastianon de São Paulo e ao geólogo Valter Baroncini da IDS - Itália pela ajuda nos processamentos.

Aos Professores de geofísica da UNESP de Rio Claro pelo empréstimo de equipamento na fase preliminar.

Ao colega de CEPAS Paulo Rodrigues de Lima, Paulinho, pelas piadas, esforço em campo e companheirismo.

À Diretoria do CEPAS, gestão 2008-2010 e à atual por permitirem e incentivarem este trabalho.

Aos momentaneamente esquecidos, obrigado.

Finalmente ao Prof. Alberto Pacheco que me incentivou nesta linha de pesquisa. 
Morrer é apenas não ser visto. Morrer é a curva da estrada.

(Fernando Pessoa) 


\section{ÍNDICE}

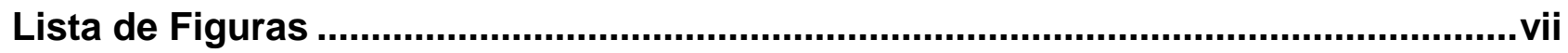

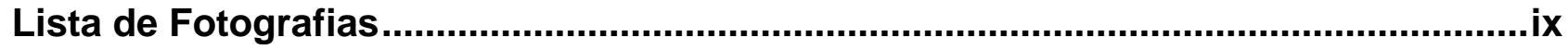

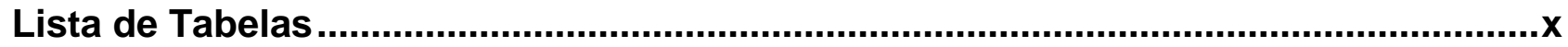

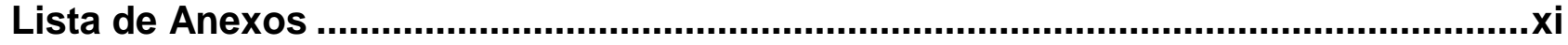

Resumo

Abstract

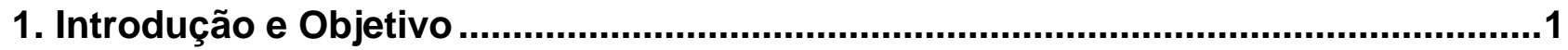

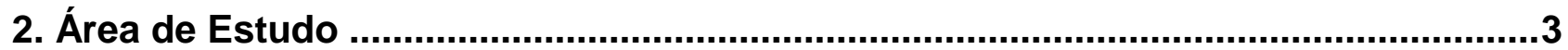

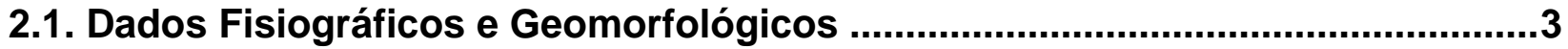

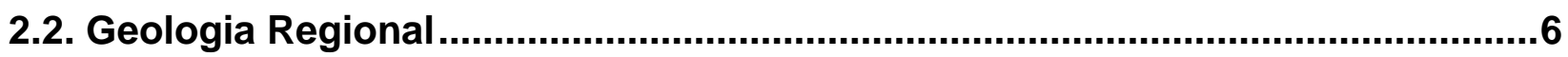

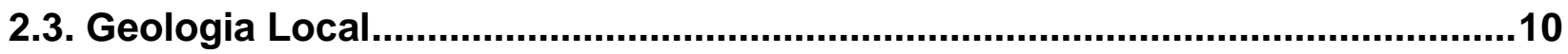

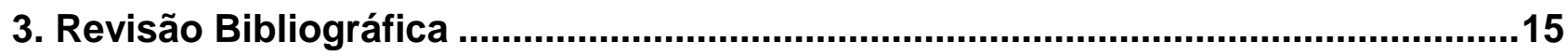

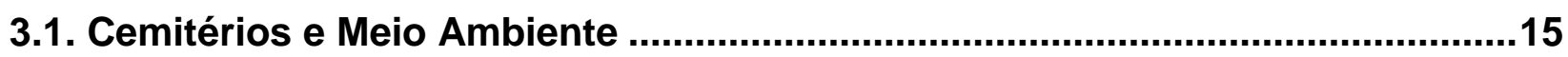

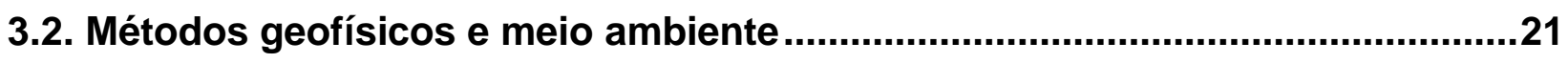

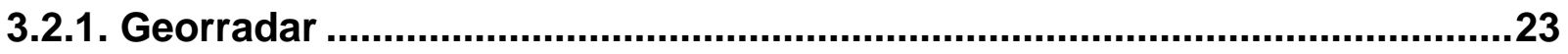

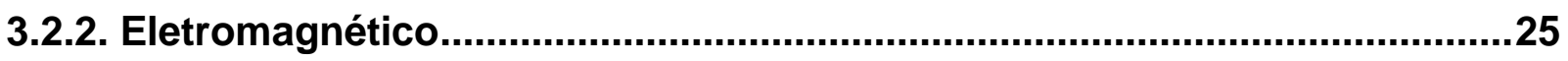

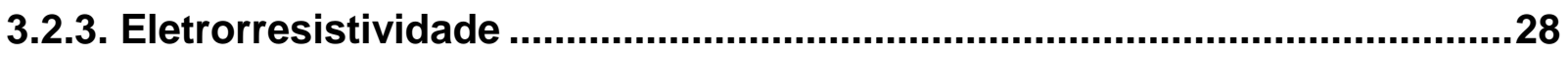

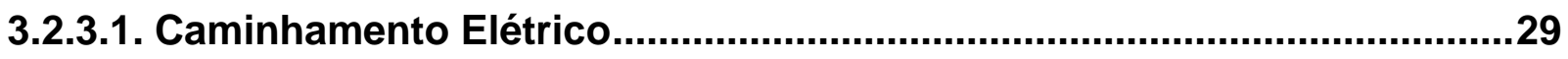

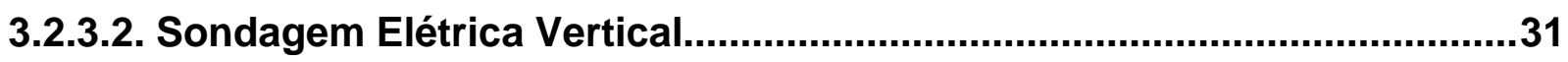

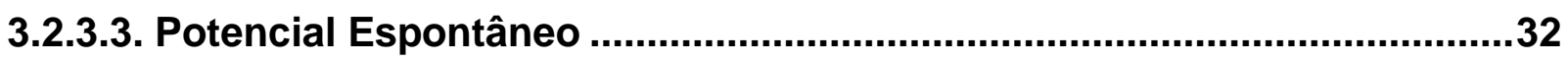

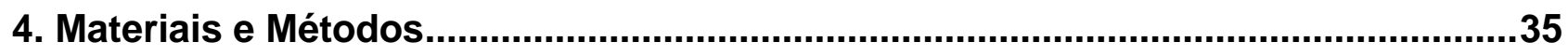

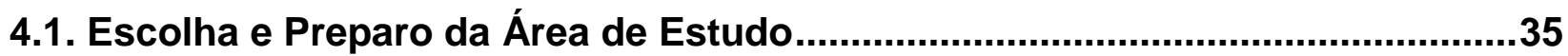

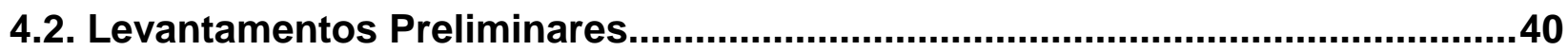

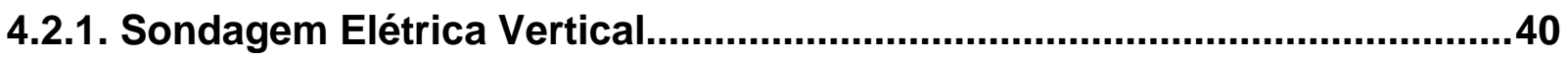

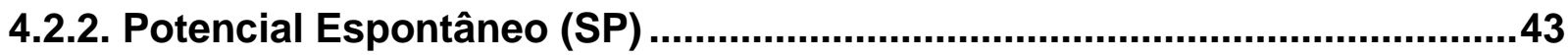

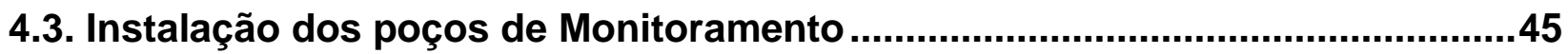

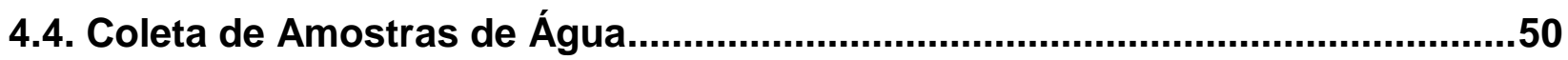

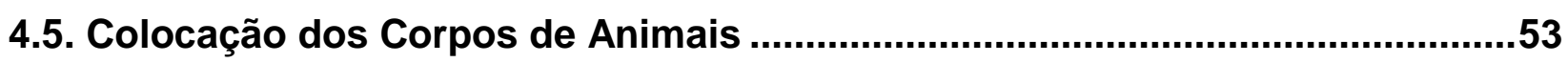

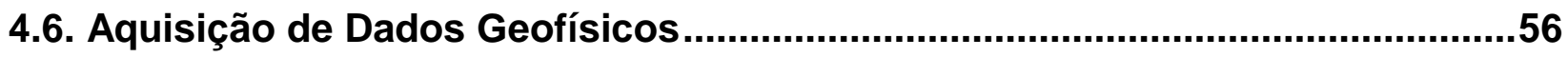

4.6.1. Levantamento Eletromagnético - EM .................................................57

4.6.2. Caminhamento Elétrico - CE...............................................................58

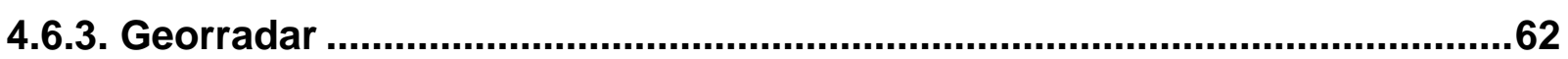




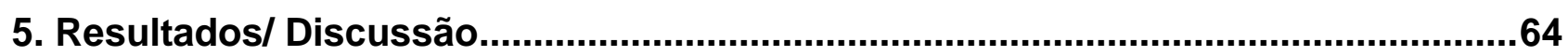

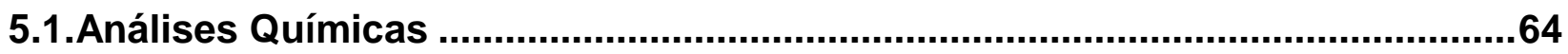

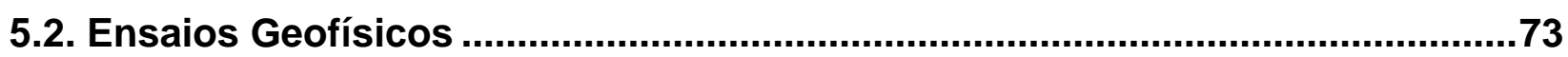

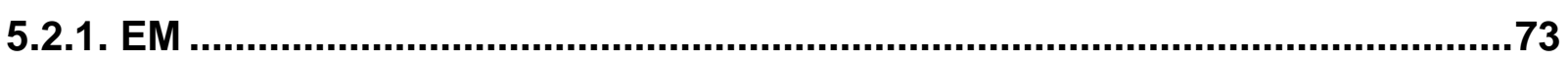

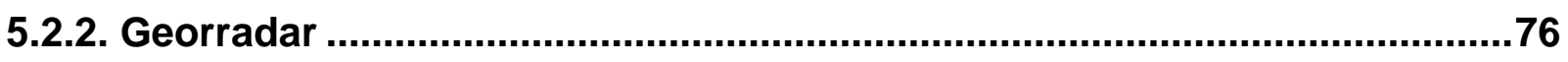

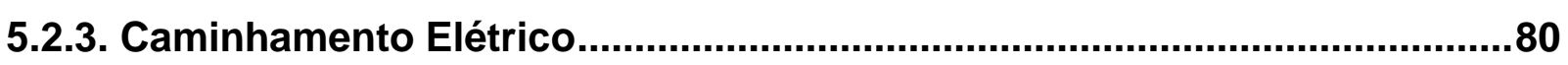

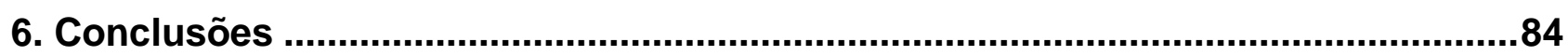

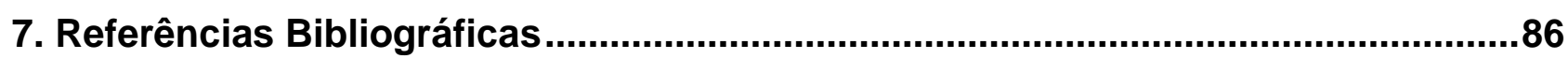




\section{Lista de Figuras}

Figura 1 - Localização da área de estudo 4

Figura 2 - Pluviometria da área de estudo 5

Figura 3 - Esquema de emissão e reflexão do sinal Georradar

na área do experimento. $\quad 24$

Figura 4 - Princípio dos Métodos Eletromagnéticos. Fonte Gallas (2007). 26

Figura 5 - Arranjo dipolo-dipolo (adaptado de Gallas et al, 2001). 30

Figura 6 - Croqui de disposição dos eletrodos no terreno para

aplicação do arranjo Schlumberger (Gallas, 2000).

Figura 7 - Potenciais de fluxo - Fenômeno "per descensum".

Fonte Braga (2001) modificado. 33

Figura 8 - Planta georeferenciada da área de pesquisa. 38

Figura 9 - Localização das SEVs efetuadas na área da pesquisa

sobre recorte da fotografia aérea adquirida. 40

Figura 10 - Gráfico da interpretação da SEV-1. 41

Figura 11 - Gráfico da interpretação da SEV-2. 42

Figura 12 - Gráfico da interpretação da SEV-3. 43

Figura 13 - Resultado do levantamento SP com medidas a cada $1 \mathrm{~m}$.

As direções de fluxo por este levantamento indicam sentido das

cores mais frias (azul e verde) para mais quentes (em laranja

e vermelho).

Figura 14- Resultado do levantamento SP com medidas a cada $2 \mathrm{~m}$.

As direções de fluxo por este levantamento indicam sentido das

cores mais frias (azul e verde) para mais quentes (em laranja

e vermelho).

Figura 15 - Esquema para cálculo do volume de poço de

monitoramento.

Figura 16 - Croquis dos levantamentos geofísicos.

Situação sem escala.

Figura 17 - Dado de campo, modelo inicial de meio homogêneo

e modelo final (Gandolfo, 2007). 
Figura 18 - Curvas de isovalores para DOC em agosto de 2008.

Figura 19 - Curvas de isovalores para DOC em outubro de 2008.

Figura 20 - Curvas de isovalores para DOC em fevereiro de 2009.

Figura 21 - Curvas de isovalores para DOC em abril de 2009.

Figura 22 - Curvas de isovalores para Cloreto em agosto de 2008.

Figura 23 - Curvas de isovalores para Cloreto em outubro de 2008.

Figura 24 - Curvas de isovalores para Cloreto em fevereiro de 2009.

Figura 25 - Curvas de isovalores para Cloreto em abril de 2009.

Figura 26 - Curvas de isovalores para Condutividade na água em agosto de 2008.

Figura 27 - Curvas de isovalores para Condutividade na água em outubro de 2008.

Figura 28 - Curvas de isovalores para Condutividade na água em fevereiro de 2009.

Figura 29 Curvas de isovalores para Condutividade na água em abril de 2009.

Figura 30 - Mapa de condutividade no campo vertical em agosto de 2008.

Figura 31 - Mapa de condutividade no campo vertical em outubro de 2008.

Figura 32 - Perfil Georradar 2D da linha 18 em agosto de 2008. As áreas com cores fortes magenta/azul representam maior amplitude de sinal. As linhas vermelhas mostram os limites da futura vala e a linha azul clara o nível do freático (N.A.) inferido do levantamento

Figura 33 - Mapa Georradar na profundidade de 2,4 m em agosto de 2008. 78

Figura 34 - Mapa de resistividade do nível 2,49m em outubro de 2008.

Figura 35 - Mapa de resistividade do nível 2,49m em fevereiro de 2009.

Figura 36 - Pseudo-seções de resistividade com os dados de campo, modelo inicial e modelo final, respectivamente de cima para baixo na figura. 


\section{Lista de Fotografias}

Foto 1 - Análise no interior do poço cacimba de jusante,

próximo da "Lagoa Seca" .

Foto 2 - Parte do perfil do solo no interior da vala com

níveis marcados.

Foto 3 - Lâmina da amostra V1 - 4 A, sem nicóis cruzados.

Aumento $100 \mathrm{x}$.

Foto 4 - Lâmina da amostra P1 - 5 A sem nicóis cruzados.

Aumento $100 \mathrm{x}$.

Foto 5 - Eletrodo da estação base na área da pesquisa.

Foto 6 - Execução da sondagem a trado com a área ainda recoberta por gramíneas

Foto 7: Detalhe da área já limpa tendo ao centro a vala demarcada.

Foto 8 - Abertura de poço de monitoramento com sonda de

4 polegadas e tripé.

Foto 9- Instalação do filtro no poço de montante (PM 01) em PVC ranhurado de 2 polegadas.

Foto 10 - Instalação do selo de bentonita. 48

Foto 11 - Abertura do poço cacimba de montante, próximo à estrada. $\quad 49$

Foto 12 - Anel e tampa de concreto sobre o poço cacimba.

Foto 13 - Área com poços de monitoramento instalados antes da abertura da vala.

Foto 14 - Parte do material separado no abate para o experimento. $\quad 54$

Foto 15 - Material lançado no interior da vala do experimento. 54

Foto 16 - Material sendo depositado na vala. 55

Foto 17 - Área recoberta após a implantação dos corpos. 55

Foto 18 - Levantamento com EM-31 na área da pesquisa. 58

Foto 19 - Levantamento por Caminhamento Elétrico. 59

Foto 20 - Levantamento por georradar na área de estudo. 63

Foto 21 - Detalhe do poço cacimba de montante na porção norte da área, impedindo o levantamento georradar nesse local. $\quad 63$ 


\section{Lista de Tabelas}

Tabela 1. Quantidade de compostos lixiviados (kg) por um corpo

humano inumado no solo. Fonte Forbes, 1987.

Tabela 2 - Resultados das análises microbiológicas na área do experimento. 


\section{Lista de Anexos}

ANEXO I - PLANILHAS DE ANÁLISES FÍSICO-QUÍMICAS

ANEXO II - MAPAS DE LEVANTAMENTO ELETROMAGNÉTICO

ANEXO III - MAPAS DE GEORRADAR

ANEXO IV - MAPAS DE CAMINHAMENTO ELETROMAGNÉTICO 


\section{Resumo}

Nos últimos 20 anos, impactos ambientais relacionados à implantação e funcionamento de cemitérios têm sido objeto de diversas discussões públicas, levantamentos ambientais e alguns trabalhos acadêmicos. A maioria das pesquisas tem demonstrado o esperado dano ambiental causado pelos cemitérios.

Para estes estudos ambientais, tanto acadêmicos quanto técnicos, os pesquisadores e profissionais têm se valido de diversas metodologias, especialmente dos métodos indiretos de investigação por sua rapidez e qualidade dos resultados.

Os métodos indiretos utilizados na avaliação e controle das contaminações por cemitérios têm sido a eletrorresistividade e os eletromagnéticos. Mais recentemente o georradar tem sido mencionado em literatura e utilizado principalmente em estudos forenses.

Neste projeto se implantou em uma área sem qualquer histórico de contaminação, corpos e restos de animais com semelhanças a corpos humanos, comparando os métodos e técnicas geofísicas no acompanhamento da formação da pluma de contaminação possivelmente originada a partir da formação do necrochorume.

Os resultados mostraram que o método da eletrorresistividade com a técnica do caminhamento elétrico apresentou os melhores resultados quanto à delimitação da pluma gerada.

Análises físico-químicas efetuadas na água subterrânea para se avaliar os resultados não mostraram claramente as alterações previstas, especialmente quanto ao esperado aumento da condutividade elétrica. 


\section{Abstract}

In recent years, environmental impacts related to the deployment and operation of cemeteries has been the subject of several public discussions, environmental surveys and academic papers. Most surveys have shown the expected environmental damage caused by cemeteries.

On the other hand, in academic and technical environmental studies, researchers and professionals have been using various methodologies, especially the indirect methods of investigation due to quickness and quality of results.

The indirect methods used in the evaluation and control of contamination caused by cemeteries has been the electrical and electromagnetic. More recently Ground Penetrating Radar has been mentioned in literature and mainly used in forensic studies.

This study implemented in an area without any history of contamination, animal bodies with similarities to human burials and compared the methods and geophysical techniques to monitor the formation of the plume of contamination probably originated from the formation of necroleachate.

The results showed that the method of electrical imaging showed the best results concerning the delimitation of the plume generated.

Physical and chemical analysis performed in groundwater to evaluate the results did not clearly show the expected changes, especially regarding the specific increase in electrical conductivity. 


\section{Introducão e Objetivo}

Nos estudos ambientais em geral, especialmente quando se pretende avaliar em escala de detalhe a existência de uma possível contaminação e o dimensionamento espacial de sua pluma, as técnicas geofísicas têm tido grande importância, constituindose mesmo em uma ferramenta indispensável (Dobecki \& Romig, 1985; Greenhouse, 1991; Steeples, 1991; Carvalho Jr \& Costa e Silva, 1997). Esta ferramenta mostra-se ainda essencial quando se pretende locar mais precisamente poços de monitoramento, propor medidas de recuperação da área afetada e cumprir as normas legais de investigação de passivos ambientais.

Nestes estudos, incluindo-se os que envolvem a presença de um cemitério ou a implantação destes empreendimentos, o conhecimento das características geológicas e hidrogeológicas do meio físico é de fundamental importância. Nestes casos a geofísica aplicada passa a ser uma ferramenta de grande valia.

Entre as aplicações possíveis, inclui-se a determinação da profundidade do nível d'água, assim como as flutuações temporais e espaciais do aqüífero, a identificação de anomalias correlacionáveis a contaminações e o mapeamento das bases geológicas e hidrogeológicas tais como profundidade do topo rochoso, determinação de diferentes estratos geoelétricos, presença de camadas argilosas e estruturas tectônicas. Para isto, estudos através da eletrorresistividade, eletromagnético indutivo e georradar têm sido amplamente utilizados, em conjunto ou isoladamente.

Os estudos voltados à identificação e investigação de áreas utilizadas para disposição de cadáveres, além de levantamentos ambientais nestes locais utilizando-se do georradar têm resultados variados. Tome-se como exemplo a tentativa de identificação de cemitérios clandestinos no Araguaia em 2001, que não obteve bons resultados. Por outro lado, estudo forense em área controlada desenvolvido por Freeland et. al. (2003) aponta para bons resultados especialmente em pequenas profundidades.

Estudos ambientais em áreas de cemitérios com a utilização deste método têm sido efetuados principalmente em laudos e relatórios técnicos de consultoria e, portanto, não noticiados em literatura especializada, mas aos quais se obteve acesso nesta pesquisa. 
Segundo Gandolfo (2007), o método da eletrorresistividade é o que encontra maiores aplicações em estudos hidrogeológicos. Particularmente, as técnicas de investigação lateral propiciam o mapeamento e delimitação de anomalias correlacionadas com plumas de contaminação, principalmente quanto à presença de compostos químicos inorgânicos que elevam a condutividade das águas subterrâneas.

A experiência de trabalhos junto ao CEPAS - Centro de Pesquisas de Águas Subterrâneas - do Instituto de Geociências da Universidade de São Paulo tem demonstrado, por outro lado, a vasta gama de aplicações do método eletromagnético, que permite ainda, por sua facilidade e rapidez de uso, levantamento de grandes áreas em curto período de tempo.

Assim sendo, julga-se de extrema importância a comparação entre estes três métodos, de forma a se avaliar qual destes oferece, sob as condições da pesquisa e local escolhidos, a melhor resposta no sentido de se obter uma representação final do substrato alterado pela contaminação oriunda da decomposição dos corpos de animais, sendo este o objetivo do trabalho.

A decomposição dos corpos de animais forma um líquido conhecido por necrochorume, similar ao formado pela decomposição de corpos humanos e também de matéria orgânica em depósitos de resíduos domiciliares - chorume, de onde vem o neologismo da palavra.

Justifica-se a utilização dos três métodos neste projeto de pesquisa pela necessidade científica de compará-los, sendo experiência inédita quando relacionada a cemitérios. A experiência acumulada tanto pelo orientador como pelo orientado em trabalhos acadêmicos realizados nos últimos anos, além de outros pesquisadores, culminou com a proposição deste trabalho. (Pacheco \& Saraiva, 2004; Pacheco et al, 2004; Pacheco \& Saraiva, 2005; Taioli e Saraiva, 2004; Bastianon et al. 2000; Matos, 2001; Carvalho Jr \& Costa e Silva, 1997; Mendes et al, 1989).

O emprego simultâneo dos três métodos em um mesmo local de estudo possibilita correlações e avaliações quanto à eficácia dos mesmos frente a determinado tipo de problema a ser solucionado. 
O parâmetro escolhido para se comparar os resultados dos três métodos foi pela instalação de poços de monitoramento que pretendeu acompanhar, através da análise química das amostras de água, a confiabilidade dos métodos aplicados.

\section{2. Área de Estudo}

A área de pesquisa (Figura 1) situa-se no Município de Pirassununga, Estado de São Paulo no interior do campus da Universidade de São Paulo - USP localizado na área rural da cidade. A área escolhida está afastada de qualquer atividade antrópica regular, sendo servida por estrada de terra de utilização pouco intensa pela comunidade do campus. O motivo da escolha será visto adiante no Capítulo 4 - Materiais e Métodos.

\subsection{Dados Fisiográficos e Geomorfológicos}

O campus USP de Pirassununga está inserido na Unidade de Gerenciamento de Recursos Hídricos - UGRHI 09 - Bacia Hidrográfica do Rio Mogi-Guaçu, situada na região nordeste do Estado de São Paulo.

Segundo os dados do DAEE -Departamento de Águas e Energia Elétrica de São Paulo, os aqüíferos presentes na área são: Cenozóico, Diabásico ou Serra Geral (capacidade de 5 a 70 m³/h), Guarani (capacidade de 50 a 600 m³/h), Passa Dois (considerado de baixo potencial), Tubarão (3 a $30 \mathrm{~m}^{3} / \mathrm{h}$ ) e Cristalino (5 a $30 \mathrm{~m}^{3 / h}$ ).

Quanto ao clima, conforme Zaine (1994) a região é definida como pertencente ao tipo Cwa segundo a classificação de Koeppen, tropical com duas estações definidas, seca no inverno e mês mais quente atingindo temperaturas acima de $22^{\circ} \mathrm{C}$, sendo controlado por massas tropicais e equatoriais que predominam em mais de $50 \%$ do ano.

Ainda segundo Zaine (1994) o regime de chuvas indica um período seco entre os meses de abril e setembro com 15 a 20 dias de chuva em média apenas nesse período. Por outro lado o período chuvoso que se estende de outubro a março tem em média de 55 a 60 dias de chuva e representa mais de $80 \%$ das precipitações anuais com a média pluviométrica de $1200 \mathrm{~mm}$. 


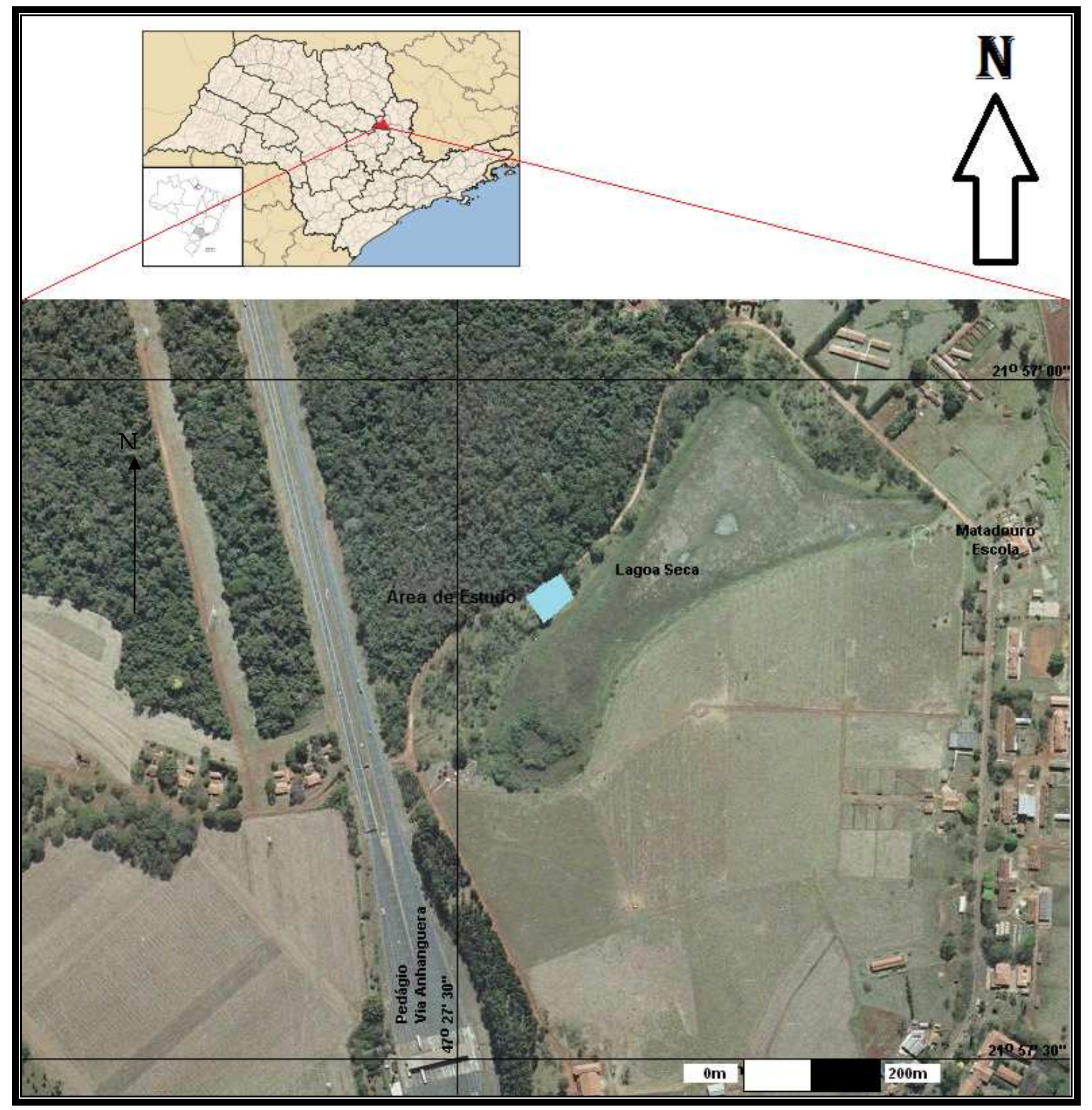

Figura 1 - Localização da área de estudo em destaque na cor azul clara.

Os dados de meteorologia do campus USP de Pirassununga (Figura 2), obtidos junto à Coordenadoria daquele campus, mostra a pluviometria da área no período de estudo deste trabalho, dados estes que concordam com a média geral exceto para o 
período inicial do projeto, quando uma forte seca atingiu a área, tendo permanecido a estiagem por mais de 30 dias nos meses de julho e agosto, além do que este período de pouca chuva se entendeu até o mês de novembro de 2008.

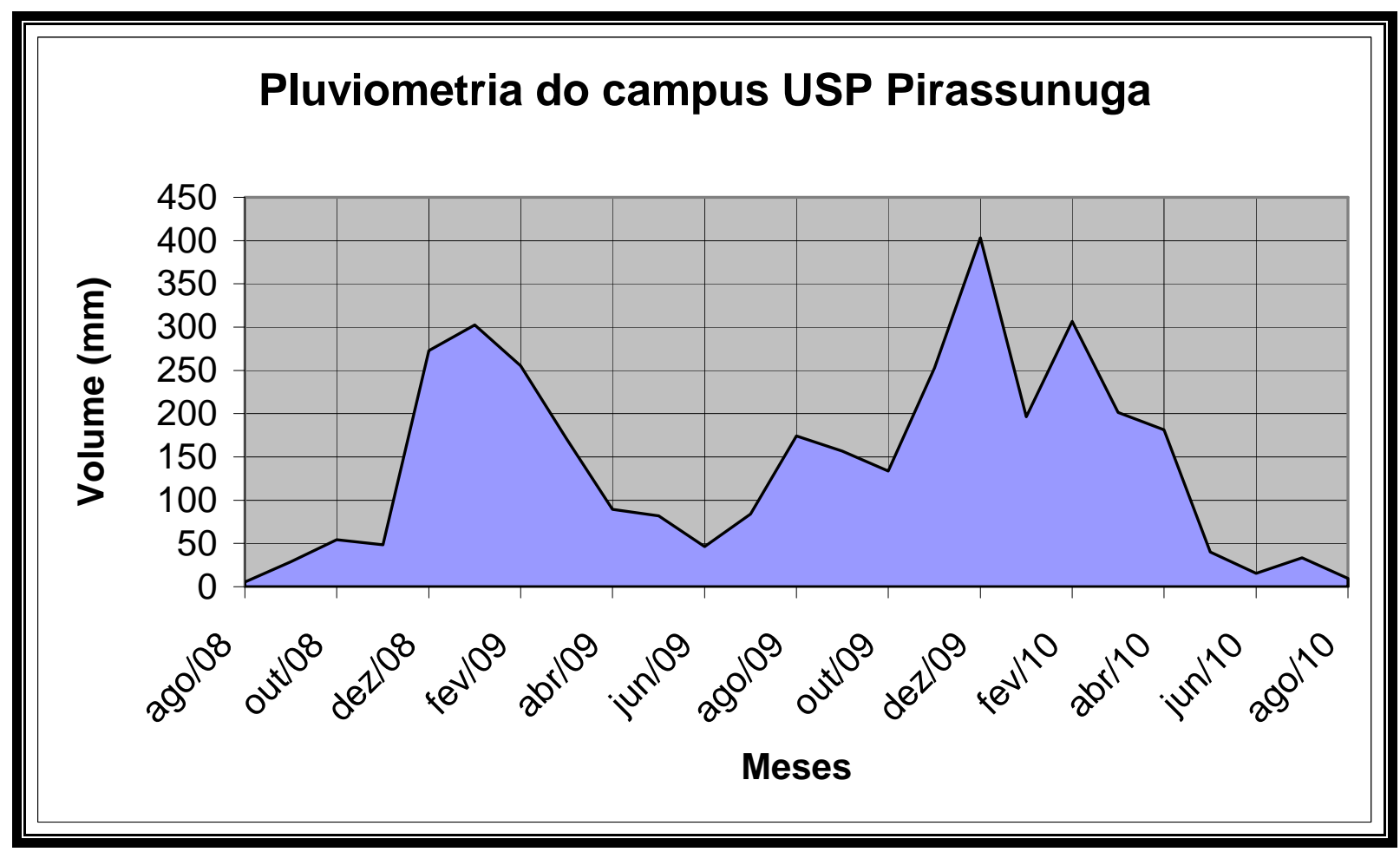

Figura 2 - Pluviometria da área de estudo. Dados: Coordenadoria do Campus de Pirassununga (http://www.usp.br/ccps/, acesso em 18 de setembro de 2010).

Geomorfologicamente a área se insere na porção centro-leste da Depressão Periférica Paulista, nomenclatura empregada pela primeira vez na subdivisão proposta do relevo paulista por Moraes Rego em 1932. Esta depressão tem sido subdividida em setores morfologicamente diferenciados, de origem tectônico-erosiva (Vieira, 1982).

Segundo Freitas et al. (1990), a depressão constitui faixa deprimida entre as escarpas do diabásio e Arenito Botucatu, que delimitam sua borda ocidental, e o Planalto Cristalino Atlântico, que delimita sua borda oriental. Ao norte, limita-se pelo alinhamento Araxá-Rio Grande (Asmus \& Ferrari, 1978), e ao sul pelo Rio Paranapanema (Fúlfaro \& Suguio, 1968 e 1974). Restringe-se ao compartimento norte da Bacia do Paraná que, segundo Vieira (1982), tem apresentado um comportamento menos ascendente que o Arco de Ponta Grossa, ao sul, desde o Permo-Carbonífero. 
Durante o Terciário, ocorreu reativação de falhas ao longo de antigas linhas de fraqueza; este processo, ativo até hoje, apresenta pulsações com diferentes ciclos de sedimentação e erosão (Fúlfaro \& Suguio, 1968).

Björnberg et al. (1968) citam pequenos blocos basculados e grandes superfícies cenozóicas adernadas em várias direções. Admitem serem recentes as manifestações tectônicas responsáveis pelas alterações geológicas e afirmam que "A Depressão Periférica se originou por atuação conjunta de fenômenos de tectônica rígida(grande número de pequenas fraturas cisalhantes, formando extensas zonas brechadas) e ação erosiva de uma drenagem subseqüente".

Almeida (1964) subdividiu a Depressão Periférica em três zonas: do Paranapanema, do Médio Tietê e do Mogi-Guaçu, delimitadas pelos divisores de água destes rios. A área enfocada no presente estudo abrange parte da zona do Médio Tietê e a maior parte da zona do Mogi-Guaçu.Tal região caracteriza-se pela maior expressão das intrusivas básicas do magmatismo Serra Geral (encaixadas nas unidades paleozóicas e mesozóicas da Bacia do Paraná), e de estruturas ativas principalmente no Mesozóico.

A Depressão Periférica apresenta relevo suave, colinoso, sustentado pelas rochas sedimentares da Bacia do Paraná. Relevo mais acidentado, de morrotes, morros e mesmo algumas serras isoladas, aparece nas regiões de intrusão de rochas básicas do magmatismo Serra Geral, sobretudo na faixa Rio Claro-Araras-Piraçununga.

\subsection{Geologia Regional}

A área escolhida situa-se na Bacia Sedimentar do Paraná, em sua porção nordeste, onde afloram rochas vulcânicas e sedimentares das eras paleozóica, mesozóica e cenozóica.

Na região afloram (Landim et al., 1980) arenitos imaturos e siltitos pertencentes ao Subgrupo Itararé e arenitos da Formação Aquidauana do permo-carbonífero, siltitos argilosos e argilitos marinhos permianos da Formação Tatuí, do Grupo Tubarão, argilitos e folhelhos cinza, de origem marinha rasa da Formação Irati, além de siltitos e argilitos cinza, também de ambiente marinho raso da Formação Corumbataí, do Permiano Superior, pertencentes ao Grupo Passa Dois. 
Os depósitos do Mesozóico se constituem de arenitos com estratificação de pequeno a grande porte, de origem predominantemente eólica, mas também alguns de origem fluvial da Formação Pirambóia. Também se encontram arenitos eólicos com estratificação cruzada de médio a grande porte da Formação Botucatu e rochas vulcânicas e intrusivas do Grupo São Bento.

As rochas Cenozóicas presentes são aquelas das formações Rio Claro e Pirassununga além de sedimentos quaternários de deposição colúvio-aluvial.

\section{GRUPO TUBARÂO}

\section{Subgrupo Itararé e Formação Aquidauana}

O Subgrupo Itararé constitui, segundo Landim et al. (1980), a unidade basal da seqüência permocabonífera da Bacia do Paraná. Segundo este autor sua origem está associada a ambientes flúvio-glacial, fluvial, marinho raso e leques aluviais. É constituída por arenitos de várias granulações, imaturos a arcóseos, conglomerados, diamictitos, tilitos, siltitos e ritmitos. Os sedimentos finos ocorrem predominantemente nas porções média e superior, e suas estruturas sedimentares são representadas por marcas onduladas, laminações cruzadas e estratificações plano-paralelas (Wu, 1981,1989).

A Formação Aquidauana, segundo Baptista et al. (1984), é formada por depósitos continentais, predominantemente arenitos vermelho - arroxeados, médios a grossos, feldspáticos e subordinadamente arenitos finos, conglomerados, siltitos, folhelhos rítmicos e diamictitos.

O Subgrupo Itararé e a Formação Aquidauana afloram em toda faixa leste da Bacia do Paraná na área da pesquisa, sobrepondo-se ao embasamento pré-cambriano. Segundo Landim et al. (1980), admite-se a interdigitação lateral entre as duas unidades, predominando os depósitos avermelhados da Formação Aquidauana a norte do rio MogiGuaçu.

\section{Formação Tatuí}

Esta Formação representa a primeira unidade pós-glacial no Estado de São Paulo (Soares e Landim, 1976). É constituída por depósitos marinhos costeiros com estratificação plano-paralela, predominando siltitos, arenitos finos, calcários e sílex com coloração avermelhada ou esverdeada, sendo esta predominante na parte superior da 
unidade. Também Freitas et al., (1979) descreveram a ocorrência dessa formação a nordeste de Leme.

\section{GRUPO PASSA DOIS}

\section{Formação Irati}

Neste trabalho adotou-se a descrição de uso consagrada de Formação Irati (Cottas, 1983), incluindo o Membro Taquaral (basal), constituído de folhelhos silticos a siltitos com níveis conglomeráticos na base, e o Membro Assistência, constituído do folhelhos argilosos betuminosos, calcários dolomíticos e alternâncias destes dois termos, com calcários dolomíticos silicificados, para o topo. À Formação Irati é atribuída sedimentação em mares rasos, com ciclos transgressivo-regressivos de menor ordem subordinados à transgressão pós-glacial na Bacia do Paraná (Hachiro, 1991).

Suas principais exposições ocorrem próximo ao distrito de Assistência, Município de Rio Claro, próximo à região de estudo.

\section{Formação Corumbataí}

Esta Formação constitui a unidade superior do Grupo Passa Dois, formada por arenitos muito finos, siltitos, lamitos e folhelhos com coloração variegada de cinza, creme, verde claro ou lilás, apresenta ainda níveis de calcário oolítico e leitos de calcário silicificado (Cottas, 1983).

As estruturas predominantes são estratificação plano-paralela, cruzada de baixo ângulo, estratificação rítmica, marcas onduladas e fraturas de ressecamento (IPT, 1981). Nos sedimentos arenosos ocorrem estratificação cruzada de pequeno porte e laminação ondulada descontínua, formada em condições de planície de maré (Cottas, 1983).

Sua ocorrência se dá de forma bastante extensa no vale do Rio Corumbataí, sofrendo afunilamento nas regiões de Leme e Pirassununga.

\section{GRUPO SÃO BENTO}

\section{Formação Pirambóia}

Constituída por espessos pacotes de arenitos finos a médios, rosados a avermelhados, apresentando estratificações cruzadas de pequeno a grande porte, com 
intercalações de níveis de siltitos e arenitos silticos, além da ocorrência de arenitos conglomeráticos no topo (Caetano-Chang et al, 1991; Caetano-Chang \& Wu, 1992).

Sua deposição é dominantemente eólica, englobando sistema fluvial marginal e leques aluviais no topo (Caetano-Chang, 1997).

\section{Formação Botucatu}

A Formação Botucatu é constituída por sucessão de arenitos eólicos avermelhados de granulação média, bem selecionados, foscos, com estratificações cruzadas de médio a grande porte (IPT, 1981).

A unidade foi depositada em condições de ambiente desértico que se estendeu por toda Bacia do Paraná, deixando registros inequívocos de campos de dunas e lençóis de areias eólicos.

\section{Formação Serra Geral}

Regionalmente destacam-se soleiras e diques de diabásio associadas ao magmatismo Serra Geral, intercaladas principalmente às formações Iratí e Tatuí; ocorrem ainda intercaladas às formações Corumbataí e Pirambóia. Segundo IPT (1981), derrames basálticos capeiam as Serras que bordejam a Depressão Periférica.

\section{DEPÓSITOS CENOZÓICOS}

Os depósitos cenozóicos se distribuem de maneira generalizada no Estado de São Paulo (Schneider et al.,1974) ocorrendo na forma de depósitos aluvionares preenchendo fundo de vales atuais, terraços, depósitos coluvionares e também constituindo as bacias terciárias de São Paulo e Taubaté, a Formação Pariquera-Açu e depósitos associados às Planícies Costeiras.

A Formação Rio Claro é descrita por Schneider et al. (1974) como sendo constituída por sedimentos arenosos, esbranquiçados, amarelados e róseos, mal consolidados. São comuns intercalações de lentes argilosas e níveis conglomeráticos e apresenta relações discordantes com as rochas do embasamento e demais formações da Bacia do Paraná.

A Formação Pirassununga ou Piraçununga de acordo com a grafia de Ferreira (2005) é composta por depósitos arenosos que recobrem indistintamente as unidades 
geológicas da Bacia do Paraná na região de Pirassununga e Porto Ferreira. Segundo a autora caracteriza-se por sedimentos areno-argilosos inconsolidados, de coloração vermelho-amarelada, estrutura de aspecto maciço com raras estratificações cruzadas.

Apresenta duas fácies principais, sendo uma conglomerática basal, constituída por seixos de quartzo, quartzito e fragmentos de siltito e outra areno-argilosa caracterizada por ser mal selecionada e possuir grãos de quartzo dispersos na matriz.

Esta formação, segundo Vieira (1982) sobrepõe-se às Formações mais antigas em discordância erosiva, cujo contato ocorre por cascalheira pouco espessa. São comuns concreções lateríticas e fragmentos retrabalhados na forma de seixos e blocos arredondados.

\subsection{Geologia Local}

A área destinada à pesquisa pertence, segundo Ferreira (2005) à Formação Pirassununga. Sua análise foi efetuada através da inspeção visual e descrição de dois poços cacimba (Foto 1) e do perfil no interior da vala onde posteriormente foram depositados os corpos (Foto 2) através das quais descreveram-se as características do solo e rochas subjacentes comprovando a existência de rochas sedimentares, ao contrário de uma das hipóteses inicialmente aventada, de que se tratava, ao menos parcialmente, de solo de alteração de diabásio.

Na superfície do solo ocorre material de cor avermelhada, argiloso com algumas porções arenosas esbranquiçadas na parte Leste.

O perfil analisado no interior da vala é nítido em campo, havendo diferenças básicas em relação à estrutura do solo, cor, presença de raízes e feições de hidromorfismo na parte basal do perfil. 


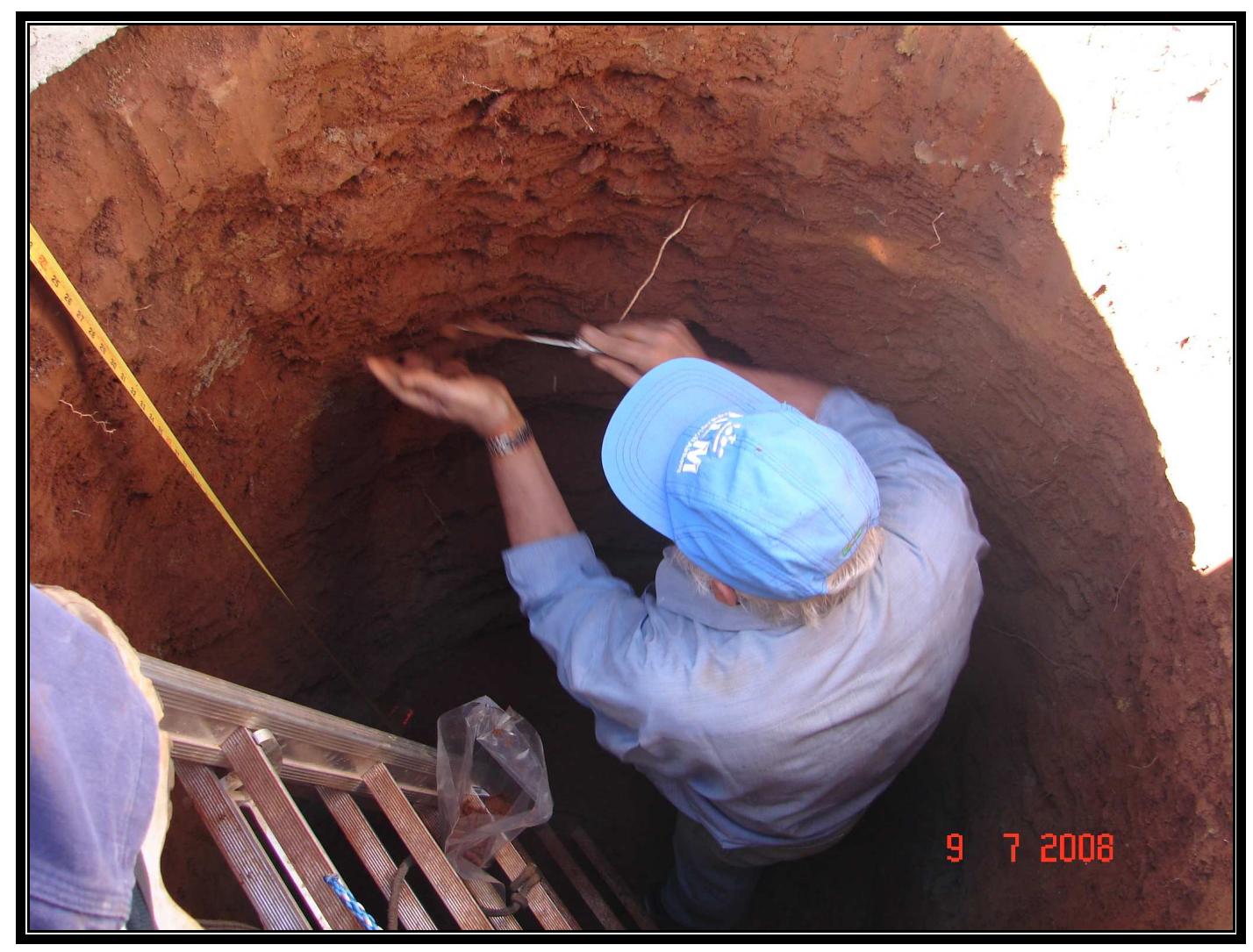

Foto 1 - Análise no interior do poço cacimba de jusante, próximo à "Lagoa Seca".

O resultado da descrição de solo efetuada em campo indicou as seguintes seqüências, para cada um dos três pontos analisados:

\section{Vala}

- V1 - 0,0 a 0,90 m. Cor 5YR46. Solo bem estruturado. Estrutura firme, poliédrica grosseira.

- Presença com média intensidade de raízes finas.

- V2 - 0,90 a 1,30m. Cor 5YR56. Solo mais solto que V1. Estrutura fraca, poliédrica fina.

- Esboroa. + friável. + amarelado e + claro que V1. Raízes grossas.

- V3 - 1,30 a 1,85m. Sem cor descrita (rocha alterada?). Mais friável que V2. Estrutura fraca, muito arenosa com grãos de quartzo límpidos.

- V4 - 1,85 a 2,50. Material amarelado com estrutura original da rocha preservada. Nódulos se formando. Preserva a estrutura da rocha com óxido de ferro formando um envoltório.

- Rocha original : Argilito, sedimentos não homogêneos. 


\section{Poço 1 (Montante, próximo da cerca)}

- P1-1 - 0,0 a 0,80 m. Cor 5YR44. Bastante compacto. Estrutura prismática média fraca. Presença de raízes finas. Poros finos. Com quartzo límpido

- P1-2 - 0,80 a 1,00m. Cor 5YR44. Camada fina. Estrutura prismática fraca. Quebrase facilmente tornando-se pó. Mais compacta que a do horizonte abaixo. Homogêneo.Porosidade elevada com poros pequenos e grandes. Raízes abundantes, finas e grossas. Muito quartzo.

- P1-3 - 1,00 a 1,50m. Cor 5YR46. Material extremamente friável, sem estrutura. Homogêneo. Poroso, com poros finos. Raízes abundantes, grossas e finas.

- P1-4 - 1,50 a 2,20. Material amarelado com muitos fragmentos de rocha, por vezes amendoados, avermelhados (ferruginizados). Manchas cinza-claras (hidromorfismo) e grande presença de manganês. Poucas raízes finas

- P1-5 - 2,20 a 4,00. Rocha alterada, dura, homogênea, ligeiramente amarelada com sinais de hidromorfia.

\section{Poço 2 (Jusante, próximo à lagoa)}

- P2-1 - 0 a 0,80. Cor 5YR46. Estrutura poliédrica grossa, bem arenoso. Quartzo límpido. Poucas raízes, finas. Porosidade fina bem desenvolvida.

- P2-2 - 0,80 a 1,15. Cor 5YR46. Estrutura prismática mais forte que P2-3. Também mais compacto que o nível abaixo. Muito quartzo, fino. Porosidade fina.

- P2-3 - 1,15 a 1,35. 5YR56. Pouco mais compacto e mais firme que P2-4, bem menos compacto que P2-2. Raízes finas em quantidade. Grãos de quartzo límpidos. Mais claro e estrutura mais fraca que P2-2.

- P2-4 - 1,35 a 1,53. 5YR 56. Horizonte com mais raízes, finas a médias, abundantes. Estrutura prismática fina, bastante friável.

Sinais de hidromorfismo (mosqueamento).

- P2-5 - 1,53 a 2,50. Gley 2510 BG. Totalmente homogêneo com manchas de hidromorfismo. Estrutura maciça sem raízes. Argiloso com fragmentos arenosos (concreção ferruginosa). 


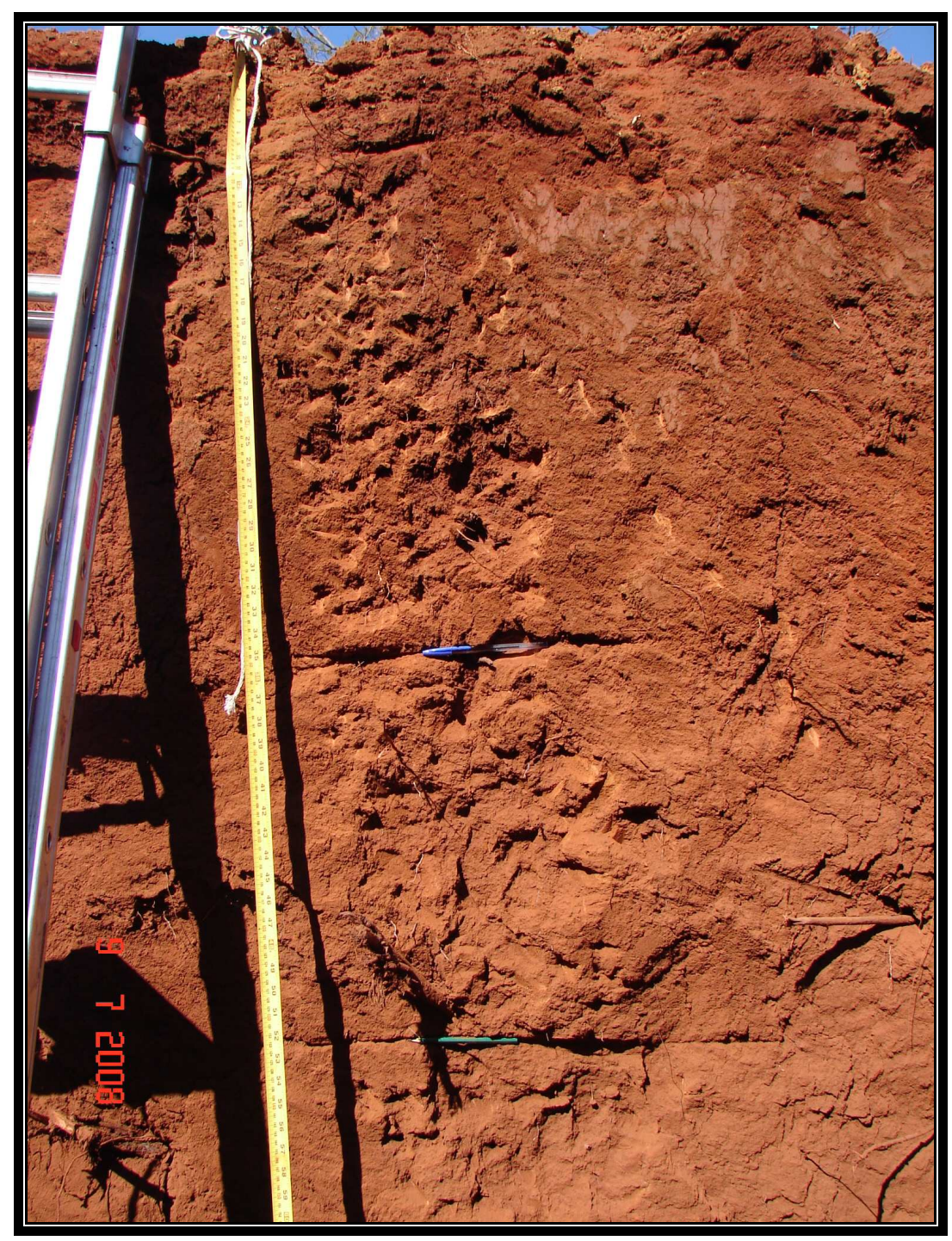

Foto 2 - Parte do perfil do solo no interior da vala com níveis marcados.

Como se pode notar nos perfis realizados, a presença de raízes finas é freqüente nos níveis superiores, mesmo que próximos aos locais onde foram perfurados os poços não existissem árvores. Também é comum neste material descrito a presença de sinais de hidromorfismo, pela variação constante do nível do freático. Esta feição também foi muito encontrada nas sondagens para instalação dos poços de monitoramento.

Foram coletadas, tanto no poço cacimba de montante como na vala, amostras para análise das lâminas em microscópio, uma vez que as amostras da porção basal destes pontos são as menos intemperizadas de todas as obtidas. As amostras foram levadas ao Instituto de Geociências e analisadas no laboratório de ótica do Departamento de Mineralogia e Geotectônica (Fotos 3 e 4). 


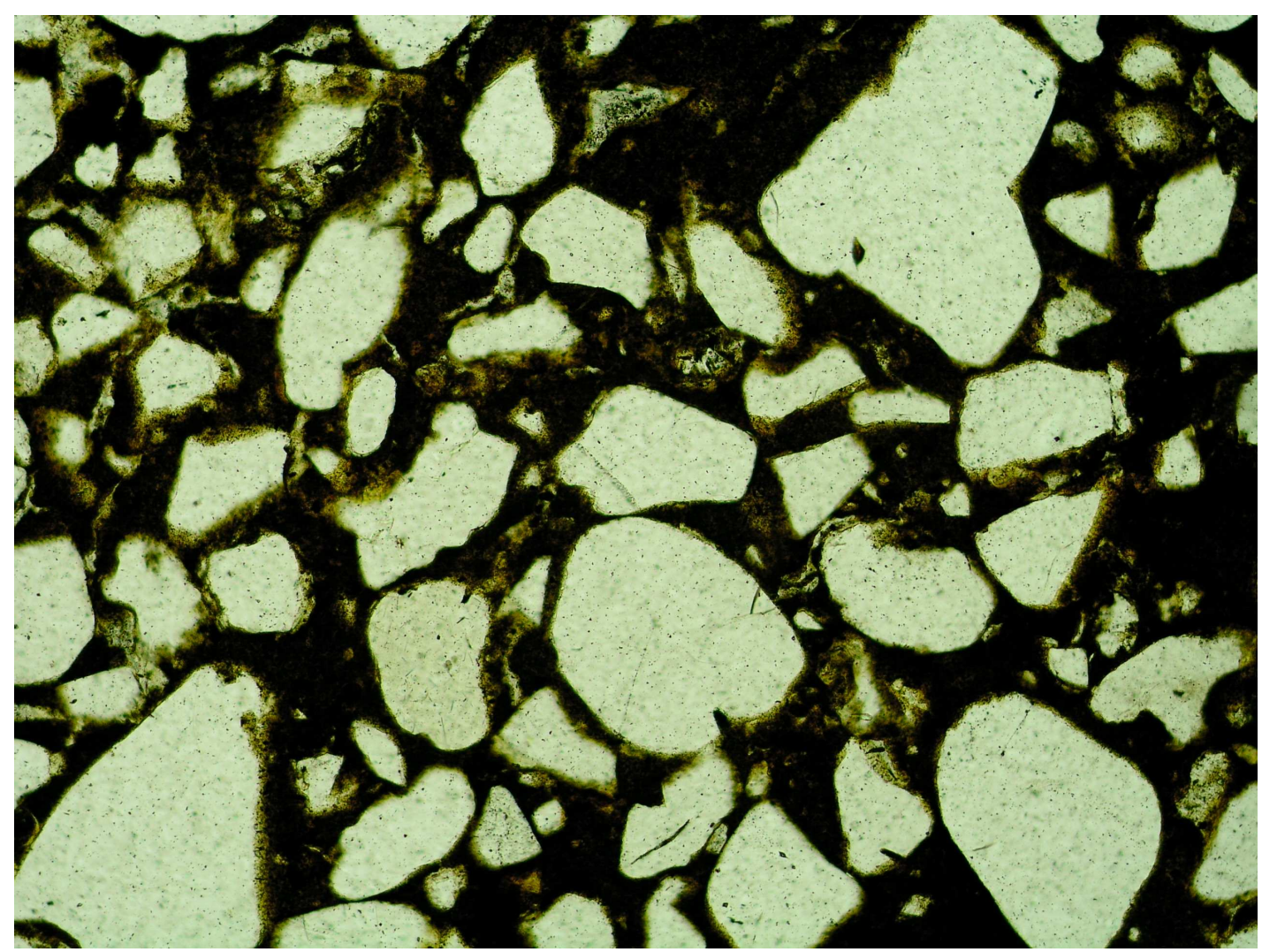

Foto 3 - Lâmina da amostra V1 - 4 A, sem nicóis cruzados. Aumento 100 x.

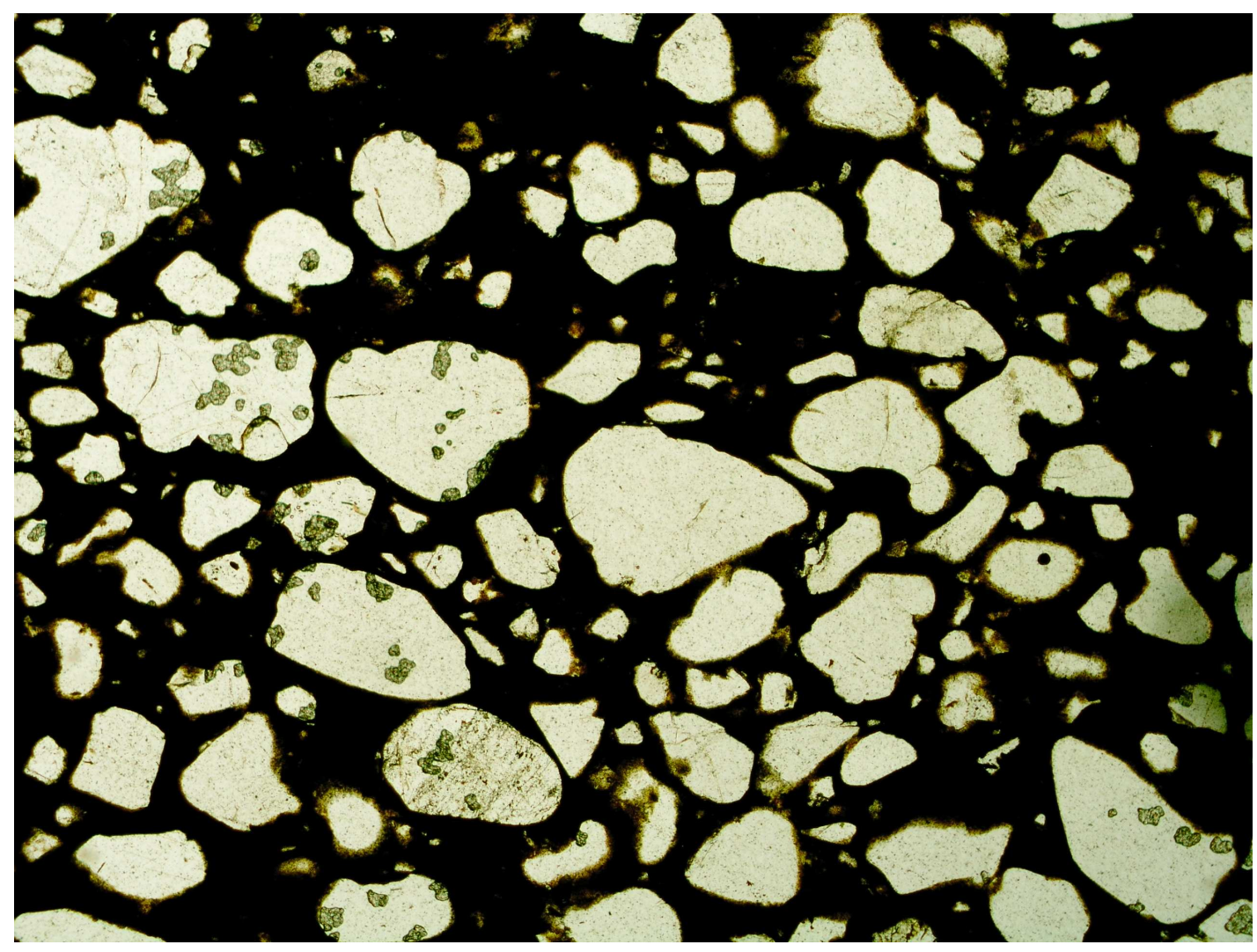

Foto 4 - Lâmina da amostra P1 - 5 A sem nicóis cruzados. Aumento 100 x. 
As amostras, denominadas de $\mathrm{P} 1$ - $5 \mathrm{~A}$ e $\mathrm{V} 1$ - 4A, retiradas de profundidades próximas se mostraram idênticas ao microscópio. A descrição feita indica que a rocha é constituída por Quartzo - 85\%, Óxido de Ferro - 15\% e Zircão como acessório. Os grãos de quartzo geralmente se apresentam bem arredondados e bem selecionados. Seus diâmetros médios situam-se predominantemente entre 0,1 e 0,4 mm, atingindo alguns grãos dimensões maiores, de até $1,5 \mathrm{~mm}$. Zircão é raro acessório. Óxido de Ferro constitui o cimento.

\section{Revisão Bibliográfica}

\subsection{Cemitérios e Meio Ambiente}

Depois de mortos os corpos se decompõem, passando por fases de destruição dos tecidos por ação de bactérias e enzimas, resultando em sua transformação em gases, líquidos e sais.

Segundo Pacheco (2000), na primeira fase com duração de três a quatro semanas, os gases desenvolvidos no interior do cadáver $\left(\mathrm{H}_{2} \mathrm{~S}, \mathrm{CH}_{4}, \mathrm{CO}_{2}, \mathrm{NH}_{3}\right.$ e $\left.\mathrm{H}_{2}\right)$ espalham-se por todo o corpo, causando a ruptura dos órgãos e tecidos. A segunda fase, importante para esta pesquisa, é chamada de coliquativa, quando ocorre a dissolução das partes moles dos cadáveres pela ação conjunta da fauna necrófaga, com duração média de até três anos. Finalmente, após a dissolução dos tecidos tem-se a fase de esqueletização.

Esta solução líquida gerada na segunda fase, chamada de liquame, putrilagem ou necrochorume, tem coloração castanho-acinzentada (Matos, 2001) sendo formada por sais minerais e substâncias orgânicas, mais viscosa e densa que a água $\left(\mathrm{d}=1,24 \mathrm{~g} / \mathrm{cm}^{3}\right)$, polimerizável e de odor característico, proveniente das mercaptanas. Sua formação se dá principalmente no primeiro ano após o enterro (Young et al., 1999)

Sob determinadas condições, em especial de ausência ou excesso de umidade nos locais de enterramento, podem ocorrer fenômenos conservativos conhecidos por mumificação e saponificação, respectivamente.

Em condições úmidas também pode se formar adipocera, que é uma substância untuosa, de cor castanha a esbranquiçada e que consiste principalmente em ácidos 
graxos e sabões de cálcio. É produzida por alterações químicas que afetam a gordura e músculos de corpos enterrados em lugares com muita água à disposição.

Conforme Silva (2000), os corpos em decomposição produzem de 30 a 40 litros de necrochorume liberados de forma intermitente. Entre os constituintes deste líquido destacam-se duas diaminas muito tóxicas: a putrescina $\left(\mathrm{C}_{4} \mathrm{H}_{12} \mathrm{~N}_{2}-1,4\right.$ Butanodiamina) e a cadaverina $\left(\mathrm{C}_{5} \mathrm{H}_{14} \mathrm{~N}_{2}-1,5\right.$ Pentanodiamina), dois venenos potentes para os quais, segundo este autor, não se dispõe de antídotos eficientes.

Estudando a hidroquímica da área do cemitério Vila Formosa em São Paulo, Migliorini et al. (1994) confirmaram que a presença desse cemitério contribuiu para o aumento na concentração de produtos nitrogenados e de íons nas águas subterrâneas do local.

Em relação à carga microbiológica, apesar da pequena bibliografia existente, Matos (2001) sugere que devem ser encontradas bactérias normalmente excretadas por seres humanos e animais, tais como Escheriria coli, Enterobacter, Klebsiella e Citrobacter, formando o grupo dos Coliformes Totais, Streptococcues faecalis e alguns clostrídeos como Clostridium perfringes e Clostridium welchii, entre outros. Segundo o autor esperase ainda encontrar bactérias patogênicas como Salmonella typhi e vírus humanos, como o enterovírus.

Por outro lado, analisando as informações de Pacheco (2000) e Silva (2000), podese supor que, sob as condições adequadas, o necrochorume decompõe-se e é reduzido a substâncias mais simples e inofensivas ao longo de determinado tempo, conforme a capacidade de depuração do meio. Esta capacidade é relacionada ao teor de argilas ativas no solo e na água desde que bem oxigenada e fluxo elevado. Se isolado, o necrochorume tende a se polimerizar, tornando-se então insolúvel e, portanto, inerte.

Entretanto, sob determinadas condições geológicas tais como aqüífero semiaflorante, o necrochorume atinge as águas de subsuperfície, causando sua contaminação. Os elementos químicos e microbiológicos provenientes desta solução ao serem introduzidos no aqüífero freático podem, através de seu fluxo, atingir distâncias consideráveis.

Estudo realizado na Alemanha citado por Bower (1978), comprovaram a existência de contaminação biológica nas águas provenientes dos cemitérios. Também na França, 
segundo Person (1979), foi feita correlação entre a endemia de febre tifóide com a localização das águas de abastecimento localizadas próximas a cemitério.

As doenças de veiculação hídrica mais comuns, possivelmente presentes nas águas advindas dos cemitérios são, segundo Matos 2001:

- Amebíase e gastrenterites, causadas por protozoários;

- Febre tifóide e paratifóide, leptospirose e cólera, causadas por bactérias;

- Gastrenterites, hepatite e infecções respiratórias, causadas por vírus.

Em relação aos aspectos químicos, diversos autores têm analisado a constituição do corpo humano e dos produtos de sua decomposição. A Tabela 1 mostra os principais elementos lançados no solo na fase coliquativa, sendo a maior porcentagem relativa à água, maior constituinte do corpo humano.

Almeida e Macedo (2005), estudando a composição aproximada do corpo humano e as fases de decomposição pelas quais o corpo passa após sua morte, analisaram os seguintes parâmetros no entorno dos cemitérios de Juiz de Fora, MG: pH, dureza e $\mathrm{Ca}^{2+}$ e $\mathrm{Mg}^{2+}$, condutividade, cloretos, amônia e nitrato. Os resultados desse estudo indicam contaminação por necrochorume pelo aumento de alguns parâmetros dentre os analisados, especialmente condutividade da água cujos aumentos se deram entre $50 \% \mathrm{e}$ $500 \%$ e cloretos com aumento entre $100 \%$ e $1200 \%$ acima do valor considerado de background.

No exterior, especialmente nos Estados Unidos, por força do costume de se preservar os corpos antes de sua sepultura, é comum a constatação de problemas originados por cemitérios em águas subterrâneas, especialmente a contaminação por formaldeído e arsênico, utilizados no embalsamamento. Além destes produtos, Spongberg \& Becks (2000) e Senos Matias et al. (2004) relatam a elevação de outros elementos, tais como ferro, chumbo e cobre possivelmente relacionada aos adornos das urnas funerárias. 
Tabela 1. Quantidade de compostos lixiviados $(\mathrm{kg})$ por um corpo humano inumado no solo. Fonte: Forbes, 1987.

\begin{tabular}{|c|c|c|}
\hline Elemento & Massa (g) & \% por peso \\
\hline $\mathrm{C}$ & 16000 & 22,9 \\
\hline $\mathrm{N}$ & 1800 & 2,57 \\
\hline $\mathrm{Ca}$ & 1100 & $\mathbf{1 , 5 7}$ \\
\hline $\mathrm{P}$ & 500 & 0,71 \\
\hline $\mathrm{S}$ & 140 & 0,2 \\
\hline $\mathrm{K}$ & 140 & 0,2 \\
\hline $\mathrm{Na}$ & 100 & 0,14 \\
\hline $\mathrm{Cl}$ & 95 & 0,14 \\
\hline $\mathrm{Mg}$ & 19 & 0,03 \\
\hline $\mathrm{Fe}$ & 4,2 & 0,006 \\
\hline $\mathrm{Zn}$ & 2,3 & 0,003 \\
\hline $\mathrm{Cu}$ & 0,07 & 0,0001 \\
\hline $\mathrm{Mn}$ & 0,01 & 0,00001 \\
\hline $\mathrm{Sr}$ & 0,32 & 0,00005 \\
\hline $\mathrm{Pb}$ & 0,12 & 0,00017 \\
\hline $\mathrm{Al}$ & 0,06 & 0,00009 \\
\hline $\mathrm{H}_{2} \mathrm{O}$ & & $70-74$ \\
\hline
\end{tabular}

Outros trabalhos levantados reportam os resultados do monitoramento de cemitérios no Brasil: Pacheco et al, 1991; Marinho, 1998; Matos, 2001; Migliorini, 2002; Bello et al. 2002; Pequeno Marinho, 2003. A análise crítica destes resultados em conjunto com os parâmetros recomendados para controle pelas legislações da CETESB (1999), da Agência Ambiental Britânica (Environment Agency, 2004), e mencionados pela Organização Mundial da Saúde - Üçisik \& Rushbrook (1998), permite identificar como indicadores físico-químicos mais importantes para o monitoramento de cemitérios as seguintes análises de água:

- Tendência de aumento do pH;

- Aumento da condutividade elétrica devido à presença de sais na solução;

- Aumento de ĺons: $\mathrm{Cl}^{-}$, carbonatos $\left(\mathrm{HCO}_{3}{ }^{-} ; \mathrm{CO}_{3}{ }^{=}\right) ; \mathrm{Ca}^{2+} ; \mathrm{Na}^{+}$.

- Aumento de nitrogênio $(N)$ como nitrato e nitrito além de fósforo $(P)$;

- Aumento de alguns metais, em particular ferro e cromo total. 
Teoricamente, com a decomposição dos corpos deveria ocorrer aumento de íons nas águas subterrâneas e, conseqüentemente, da condutividade elétrica. $\mathrm{Na}$ prática, entretanto, alguns resultados não têm confirmado esta situação.

A formação de adipocera em ambiente rico em água, porém não necessariamente saturado, ocasionou eventualmente a manutenção do pH ácido do meio (Fielder et al., 2004), ao contrário de estudos que mencionam aumento de $\mathrm{pH}$, como os trabalhos de Hopkins et al. (2000) e Rodriguez e Bass (1985). Nestes locais, onde o ambiente se tornou mais alcalino não há, entretanto, informação de que tenha se formado adipocera.

Como consequência da formação de adipocera, Fielder et al. (2004) relatam inclusive que não houve aumento de $\mathrm{C}$ total e $\mathrm{N}$ total em amostras retiradas sob os túmulos. O solo descrito para o local destes estudos é de areia siltosa, propício à decomposição dos corpos enterrados.

Estudando quatro tipos de solo na cidade do Porto, em Portugal, Durães et al. (2009) demonstraram algumas características positivamente associadas à formação de adipocera e que causam problemas na degradação dos corpos e, portanto, na liberação dos elementos constituintes.

Almeida e Macêdo analisaram parâmetros físico-químicos na caracterização de contaminação de água subterrânea por necrochorume e, em seus resultados notam-se diminuição da condutividade elétrica em dois cemitérios analisados, sendo que em um deles os valores diminuíram de uma média de $74 \mathrm{mS} / \mathrm{cm}$ para $13 \mathrm{mS} / \mathrm{cm}$.

Engelbrecht (1998) estudando cemitério municipal na cidade do Cabo, África do Sul, reporta também resultados de condutividade na água analisada da ordem de 14 a $1360 \mathrm{mS} / \mathrm{cm}$, ou seja, com uma variação anormal mesmo dentro da área tida como totalmente contaminada.

Castro (2008) em seu trabalho no Cemitério Bom Jardim em Fortaleza, CE analisou amostras de água no interior e fora do cemitério e constata que as anomalias químicas possivelmente geradas pelo cemitério são insuficientes para demonstrar cabalmente seu potencial contaminador. Ao contrário, vários elementos se mostram menos concentrados nas águas interiores do cemitério do que nas amostras provenientes de fora deste.

McBride (1994), estudando os efeitos da matéria orgânica no solo associada com argilo-minerais mostra que esta tem influência extremamente importante nas propriedades físicas, em especial na retenção de íons, nominadamente $\mathrm{Ca}^{+2}, \mathrm{Mg}^{+2}, \mathrm{~K}^{+}, \mathrm{NH}^{+4}, \mathrm{Fe}^{+3} \mathrm{e}$ 
$\mathrm{Cu}^{+2}$ pela troca catiônica, o que pode ocorrer na área, com grande quantidade de matéria vegetal proveniente de raízes.

Apesar de algumas situações que mostram resultados discordantes, de acordo com os trabalhos consultados, os cemitérios são considerados áreas com potencial para gerar contaminação ambiental em vários níveis:

1. no ar, pela liberação de gases tais como sulfídrico, dióxido de carbono, mercaptanas, metano, amônia e fosfina;

2. no solo e águas subterrâneas por compostos orgânicos, por exemplo ácidos graxos voláteis resultantes da fermentação anaeróbia, principalmente ácido butírico e propiônico, compostos fenólicos e glicéricos resultantes da decomposição de proteínas e gorduras e pelo aumento na concentração de sais (p. ex. $\mathrm{HCO}_{3}{ }^{-}, \mathrm{Cl}^{-}, \mathrm{Ca}^{2+}$ ) e metais $\left(\mathrm{Fe}^{2+}, \mathrm{Al}^{3+}, \mathrm{Pb}^{2+}, \mathrm{Zn}^{2+}\right.$ e $\mathrm{Cu}^{2+}$ ) (Spongberg \& Becks, 2000), frequentemente associados a aumentos da condutividade elétrica (Dent et al. 2004; Bastianon et al. 2000);

3. outros elementos poluentes podem ser lixiviados da decomposição das urnas, especialmente quando enterradas em solos de $\mathrm{pH}$ baixo, tais como os óxidos metálicos de $\mathrm{Ti}, \mathrm{Cr}, \mathrm{Cd}, \mathrm{Pb}, \mathrm{Fe}, \mathrm{Mn}, \mathrm{Hg}, \mathrm{Ni}$, entre outros, presentes nos adornos, vernizes e conservantes da madeira (Spongberg \& Becks, 2000);

4. microorganismos, tais como bactérias, vírus e fungos (Pacheco et al., 1991; Matos, 2001) também podem estar presentes no solo e água, podendo atingir populações do entorno que tenham contato ou se abasteçam destas águas.

Para comparação com os métodos geofísicos neste trabalho, entende-se que apenas análises físico-químicas são necessárias, uma vez que estas devem mostrar alterações dos elementos que modificam as propriedades geoelétricas do substrato.

Os parâmetros escolhidos estão dentre os indicados para monitoramento de cemitérios nos trabalhos consultados, especialmente na norma do Reino Unido (Environment Agency, 2002) e no trabalho de Üçisik \& Rushbrook (1998) sobre o impacto dos cemitérios no ambiente e saúde pública. 
Também no trabalho de Tredoux et al. (2004) são mencionados, especificamente para monitoramento de áreas de cemitérios, parâmetros escolhidos neste trabalho além de carbono total, carbono dissolvido e demanda de oxigênio.

\subsection{Métodos geofísicos e meio ambiente}

São inúmeros os trabalhos científicos relacionados a diagnósticos ambientais, hidrogeológicos e geotécnicos utilizando os métodos geofísicos aplicados neste estudo, por exemplo Elis (1998), Gallas et al. (2005), Moreira et al. (2007) e Apparao et al. (1992 e 1997). Entretanto, pouco ou nenhum conhecimento se tem de uma comparação destes três métodos voltada para a análise de contaminação por cemitérios.

Em algumas situações mais de uma metodologia é estudada conjuntamente como, por exemplo, Pellerin (2001) que compara os diversos métodos geofísicos e sua aplicação na área ambiental e geotécnica.

Alguns trabalhos analisam técnicas diferentes para a área ambiental, por exemplo, Moreira et al. (2007) que utilizaram as técnicas da Sondagem Elétrica Vertical e Caminhamento Elétrico no estudo de área contaminada por lançamento de efluentes de tratamento de esgotos, apontando para o bom resultado obtido com o $\mathrm{CE}$.

Também em arqueologia os métodos têm sido empregados para determinação de antigos cemitérios (Archaeo-physics, 2005).

Especificamente para avaliação ambiental de cemitérios com uso de geofísica são poucos os trabalhos encontrados, por exemplo, o de Bastianon. et al. (2000) no estudo do Cemitério de Vila Nova Cachoerinha, Senos Matias et al. (2004) em Portugal e Silva \& Malagutti Filho (2010) empregando o imageamento elétrico. Mais comuns são os textos voltados às pesquisas forenses (Bevan, 1991; Nobes, 1999) mas, como foi dito, normalmente empregando-as complementarmente e não comparativamente.

A aplicação dos métodos geofísicos para avaliação da adequabilidade geológica e ambiental de uma determinada área visando a implantação de empreendimentos, em especial os potencialmente contaminadores, encontra também exemplos quando se trata da implantação de cemitérios (Gallas \& Birelli, 1993 e Peluso et al. 2006 ).

Um dos primeiros trabalhos a utilizar estes métodos indiretos na avaliação da qualidade das águas subterrâneas sob influência de cemitérios foi executado por Mendes 
et al (1989), abrindo uma nova linha de pesquisa dentro do CEPAS - Centro de Pesquisas de Águas Subterrâneas do Instituto de Geociências da USP.

Em Portugal, Senos Matias et. al (2004), estudaram dois cemitérios de Aveiro utilizando georradar e equipamento eletromagnético (EM-34). Neste trabalho os autores utilizaram o georradar como complemento do levantamento eletromagnético, para refinamento dos dados obtidos, sem comparar diretamente os métodos quanto ao resultado alcançado.

Com o método da eletrorresistividade, encontram-se aplicações particularmente na tomografia elétrica de cemitérios (Lima \& Sato,1993; Aristodemou \& Thomas-Betts, 2000; Bratus \& Yabar, 2001; Schoor, 2002; Seaton \& Burbey, 2002; Carvalho Jr \& Costa e Silva, 1997) ou em áreas similares, por exemplo aterros (Ogilvy et al., 2002). Todos os trabalhos detectaram, com bons resultados, anomalias no solo originadas pelas sepulturas, corpos e materiais enterrados.

Trabalhos interessantes na área forense que mostram a aplicação dos métodos geofísicos na procura por enterramentos clandestinos utilizando-se a eletrorresistividade são descritos por Pringle \& Jervis (2010) e Pringle et al. (2010). No primeiro trabalho os autores executaram campanha com linhas espaçadas em 1 metro e dipolo de $0,5 \mathrm{~m}$ em uma área definida pela polícia inglesa como suspeita de enterramento de vítima de homicídio. No segundo, testa-se a mesma metodologia com uso de corpos de porcos enterrados simulando covas com corpos humanos e as alterações de condutividade no solo que estas provocam.

O georradar encontra inúmeras aplicações em estudos hidrogeológicos, através da determinação da profundidade do nível d'água e mapeamento de determinados tipos de contaminantes em subsuperfície (Davis \& Annan, 1989; Beres \& Haeni,1991; Johnson, 1992; Brewster \& Annan, 1994; Young \& Sun, 1996; Cardimona, et al., 1998; Nascimento et al.,1998; Endres et al., 2000; Castro et al.,2001 Bentley \& Trenholm, 2002).

Há notícias de alguns poucos trabalhos de consultoria técnica executados para cemitérios públicos ou privados, principalmente visando dirimir dúvidas quanto à possível contaminação do aqüífero. Esses relatórios, em pequeno número, ainda não constam de publicações ou acervos para consulta pública. 
Este uso deveria se intensificar após a Resolução CONAMA 335 de 03 de abril de 2003, que implementou regras para implantação de cemitérios em todo o território nacional. Entretanto, apenas em 2010 se teve notícia do lançamento de edital de contratação de empresas de consultoria para levantamento de passivo ambiental de cemitérios da Prefeitura de São Paulo.

O embasamento teórico para a aplicação dos métodos requer o conhecimento detalhado de alguns princípios e fundamentos relacionados à configuração dos eletrodos, profundidades de investigação, resoluções, possibilidades e limitações dos métodos etc. Neste sentido, foi feita consulta a trabalhos básicos, por exemplo: Roy \& Apparao, 1971; Coggon, 1973; Edwards, 1977; Fox et al., 1980; Barker, 1989; Davis \& Annan, 1989; Apparao et al., 1992; Apparao et al., 1997; Gallas, 2000 e Gandolfo, 2007, dentre outros.

Conforme proposto, três metodologias básicas foram utilizadas comparativamente na pesquisa, buscando determinar qual oferece melhor resposta ao ambiente e às condições criadas, quais sejam: Georradar, Eletromagnético Indutivo e Eletrorresistividade. Além dessas, na análise preliminar da área escolhida foram utilizados a técnica da Sondagem Elétrica Vertical - SEV e método do Potencial Espontâneo - SP, o primeiro para determinação da profundidade do nível freático e o segundo para indicar a direção do fluxo subterrâneo.

Os métodos e técnicas utilizados são descritos a seguir.

\subsubsection{Georradar}

O Georradar ou Radar de Penetração no Solo é um método de investigação geofísica que se fundamenta na emissão e recepção de ondas eletromagnéticas de alta freqüência (10 a $2000 \mathrm{MHz}$ ) em subsuperfície.

O funcionamento do método georradar se baseia na seguinte sistemática: um pulso de energia eletromagnética é irradiado para o interior do solo por uma antena transmissora (Figura 3), a energia refletida é captada pela antena receptora, sendo o sinal, então, amplificado, formatado, armazenado e apresentado na tela de um notebook. 
As reflexões da onda eletromagnética em subsuperfície ocorrem nas interfaces de materiais com diferentes propriedades físicas. A propriedade envolvida neste fenômeno é a permissividade dielétrica, que é expressa pela constante dielétrica "K".

O georradar fornece seções contínuas em tempo real (distância percorrida $x$ profundidade) dos perfis executados em campo, proporcionando o imageamento em alta resolução das estruturas ou feições em subsuperfície.

A utilização do georradar possibilita a avaliação de forma contínua das feições ao longo dos perfis realizados, permitindo identificar possíveis anomalias, descontinuidades, interferências enterradas e estruturas geológicas, otimizando desta forma os custos dos levantamentos.

Apresenta-se como uma importante ferramenta geofísica para investigação detalhada de alvos rasos e de pequenas dimensões, auxiliando na caracterização ambiental e geológica.

O georradar pode ainda auxiliar na determinação da profundidade do N.A. A água subterrânea constitui um elemento detectável devido às suas características, pois apresenta elevado valor da constante dielétrica, quando comparada com o meio geológico em geral (Davis \& Annan, 1989). A presença de água confere ainda o aumento da condutividade elétrica nas formações, principalmente se forem observados altos teores de sais dissolvidos, o que eleva os valores de condutividade muito acima do "background" da área.

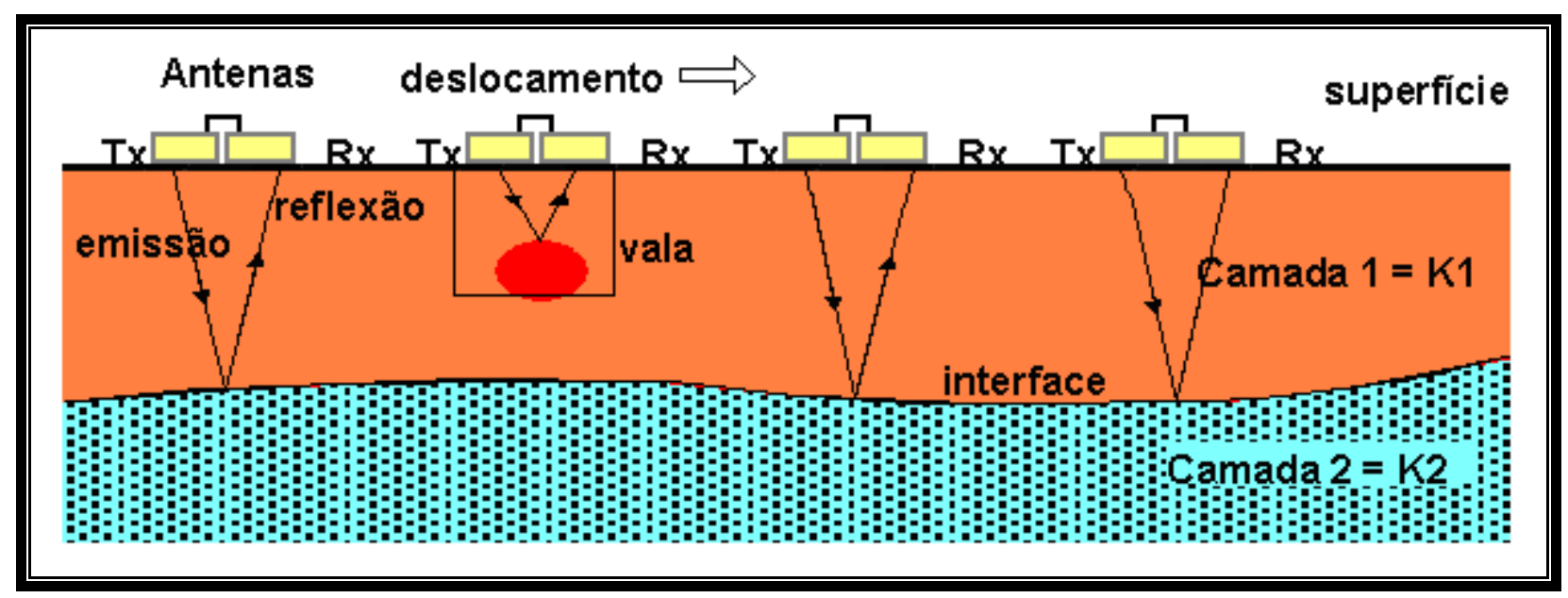

Figura 3: Esquema de emissão e reflexão do sinal georradar na área do experimento. 
$\mathrm{Na}$ investigação, entre as feições procuradas nas seções processadas, está a interface indicativa da camada saturada e, dentro desta, a extensão da possível contaminação causada pelo necrochorume. Quando o substrato o permite, são visualizadas as figuras de difração formadas quando o perfil do georradar cruza perpendicularmente os corpos enterrados, determinando seus posicionamentos.

A frequência da antena é escolhida de modo a fornecer a melhor relação entre a penetração e a resolução para um determinado objetivo, lembrando que, em princípio, menores frequências penetram mais profundamente no meio, porém apresentam resolução menor com respeito à delimitação do objetivo.

Para este estudo, foi escolhida a antena de $100 \mathrm{MHz}$, a de menor frequência dentre as existentes no acervo do IGc USP e com possibilidade de uso no projeto e também devido a sua relativa boa penetração no ambiente geológico da área da pesquisa.

\subsubsection{Eletromagnético}

Outro método geofísico utilizado, chamado de eletromagnético (EM) ou de indução, emprega campos eletromagnéticos gerados por correntes alternadas de origem artificial ou natural.

Esse método (Gandolfo, 2007) baseia-se na medida da condutividade elétrica $(\sigma)$ ou parâmetros a ela relacionados dos materiais em subsuperfície através da utilização de campos eletromagnéticos induzidos no terreno e gerados por correntes alternadas de origem natural ou artificial, sendo expressa em Siemens por metro $(\mathrm{S} / \mathrm{m})$ ou suas divisões.

A Figura 4 ilustra o princípio desses métodos. 


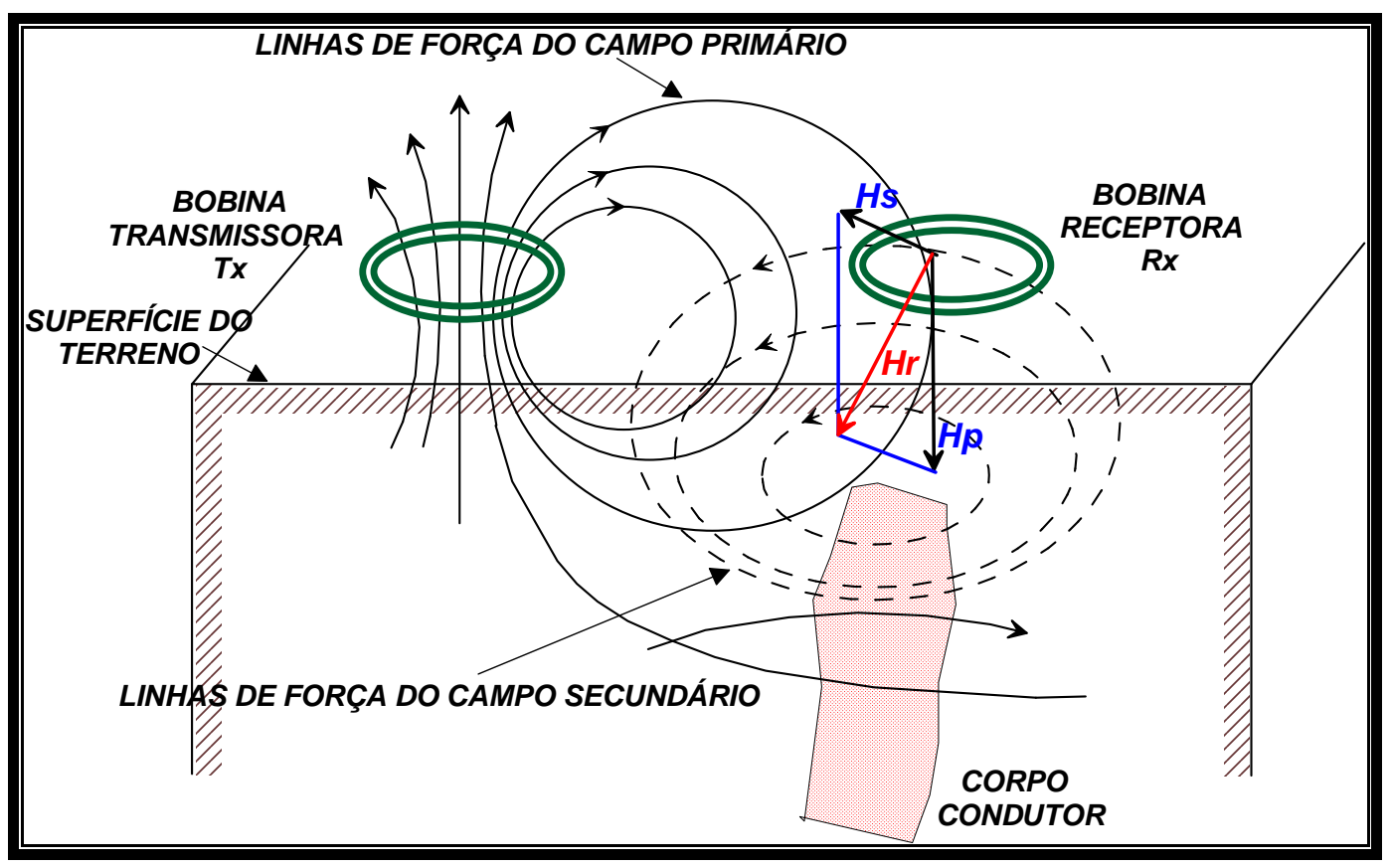

Figura 4 - Princípio dos Métodos Eletromagnéticos. Fonte: Gallas (2007).

As profundidades investigadas pelos métodos EM são inversamente proporcionais às freqüências empregadas. Existem sistemas EM que operam com diversas freqüências, permitindo uma investigação multinível, possibilitando a construção de seções geoelétricas, a exemplo do imageamento por eletrorresistividade.

Atualmente os métodos EM são empregados, além da prospecção mineral, em prospecção hidrogeológica, geologia de engenharia e geologia ambiental.

O menor custo e maior rendimento dos métodos eletromagnéticos, comparados à eletrorresistividade, têm sido motivos de seu emprego. Entretanto, sua aplicação depende da ausência de interferências e outros condicionantes geológicos e físicos.

Outra vantagem é que se trata de um método indutivo, não requerendo um contato galvânico com o terreno (cravação de eletrodos metálicos), indispensável para os métodos elétricos. Em situações de elevadas resistências de contato ou áreas pavimentadas, esta pode ser uma limitação para o uso da eletrorresistividade (Gallas, 2007). 
O método é bastante eficaz no recobrimento de extensas áreas devido a rapidez do levantamento de campo. O grande volume de dados gerados permite a elaboração de mapas de isovalores no reconhecimento da área investigada.

Em determinadas circunstâncias é afetado por ruídos elétricos e por efeitos devidos a coberturas condutivas, que podem impedir a penetração do campo EM às profundidades de interesse.

O instrumento empregado neste trabalho foi o EM-31, fabricado pela empresa canadense Geonics. Trata-se de um equipamento constituído de duas bobinas, uma transmissora e outra receptora, conforme exposto anteriormente. Este instrumento foi escolhido a partir da profundidade assumida para o aqüífero freático e a profundidade teórica de investigação do instrumento.

É um sistema eletromagnético usado extensivamente em casos relacionados às questões ambientais, hidrogeologia e geotecnia. Este sistema mede diretamente a condutividade, que é inversamente proporcional à resistividade elétrica $(\rho=1 / \sigma)$. Existindo esta relação direta e simples, é perfeitamente possível correlacionar as medidas EM a levantamentos de eletrorresistividade pré-existentes.

Seu funcionamento é explicado por Gallas (2007): "Consideremos uma bobina transmissora $\boldsymbol{T} \boldsymbol{x}$ energizada com corrente alternada colocada sobre um terreno (assumido como uniforme) e uma bobina receptora $\boldsymbol{R} \boldsymbol{x}$ posicionada a uma curta distância $\boldsymbol{s}$. Estas correntes geram um campo magnético secundário Hs que é captado, juntamente com o campo primário $\mathrm{Hp}$ na bobina receptora. O campo magnético secundário é uma função da distância entre bobinas $\boldsymbol{s}$, da freqüência $\boldsymbol{f}$ e da condutividade $\sigma$ do terreno, expressa como:"

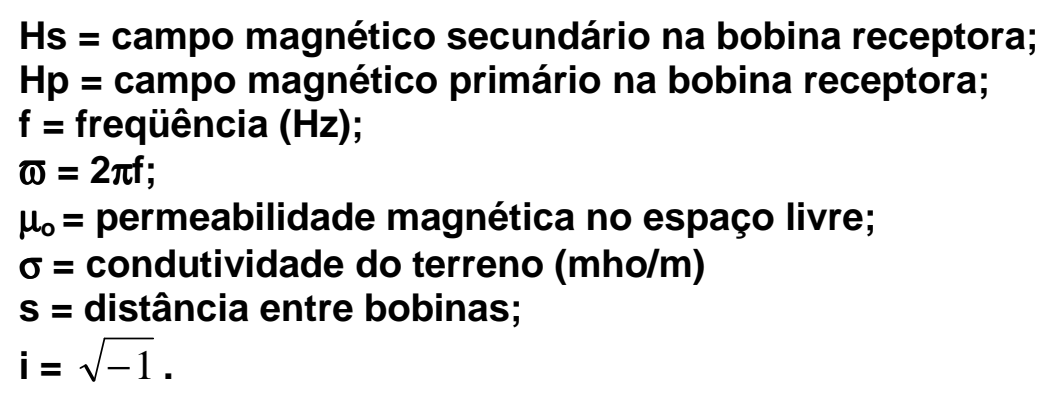


De acordo ainda com Gallas (2007) e Gandolfo (2007), "A relação entre os campos magnéticos secundário e primário fica linearmente proporcional à condutividade do terreno, tornando possível a leitura direta das condutividades medindo-se esta relação". Obtendo-se $H s / H p$, a condutividade aparente indicada pelo EM-31 é dada por:

$$
\sigma_{a}=\frac{4}{\varpi \mu_{0} s^{2}}\left(\frac{H_{s}}{H_{p}}\right)
$$

O sistema permite a operação com as bobinas orientadas de duas maneiras, de modo a orientar o campo eletromagnético nas posições vertical e horizontal. Desta forma, os pacotes de solo analisados, em função da separação entre as bobinas do aparelho foram respectivamente de 0 a $3 \mathrm{~m}$ (pacote raso analisado), quando utilizado o campo horizontal e de 0 a $6 \mathrm{~m}$ (pacote profundo analsiado) quando utilizado o campo vertical.

\subsubsection{Eletrorresistividade}

O método da eletrorresistividade possui base teórica pormenorizada em diversos autores, entre os quais podemos citar Maillet (1947), Keller \& Frischknecht (1966), Orellana (1972), Telford et al. (1990) e mais posteriormente Reynolds (1997).

De acordo com Telford et al. (1990), emprega uma corrente elétrica artificial que é introduzida no terreno através de dois eletrodos (denominados de A e B), com o objetivo de medir o potencial gerado em outros dois eletrodos (denominados de $\mathrm{M}$ e $\mathrm{N}$ ) nas proximidades do fluxo de corrente, permitindo assim obter a resistividade aparente através da expressão:

$$
\rho=K \cdot \frac{\Delta V}{I}
$$

Na expressão anterior $\rho$ é a resistividade elétrica (ohm.m), K é o fator geométrico que depende das posições dos eletrodos no terreno, $\Delta \mathrm{V}$ é a diferença de potencial entre 
os eletrodos $\mathrm{M}$ e $\mathrm{N}$ e I a intensidade de corrente que passa entre os eletrodos $\mathrm{A}$ e $\mathrm{B}$. $\mathrm{O}$ fator $\mathrm{K}$ pode ser calculado através da equação geral:

$$
K=\frac{2 \pi}{(1 / A M)-(1 / A N)-(1 / B M)+(1 / B N)}
$$

A resistividade elétrica relaciona-se aos mecanismos de propagação de corrente elétrica nos materiais. Em geral, propagação de corrente elétrica em solos e rochas se dá devido ao deslocamento de íons dissolvidos na água contida nos poros e fissuras, sendo afetada principalmente pela composição mineralógica, porosidade, teor em água e quantidade e natureza dos sais dissolvidos. Dentre esses fatores, os mais importantes são, sem dúvida, a quantidade de água contida e a salinidade dessa água.

O aumento do teor de umidade e da quantidade de sais dissolvidos causa uma diminuição dos valores de resistividade. Essa condição é que permite a imensa possibilidade de aplicação do método em estudos ambientais e hidrogeológicos, onde a presença de água da zona saturada e o aumento da quantidade de contaminantes ricos em sais podem ser detectados pelo método, por exemplo em Gallas et al. (2005 e 2010).

\subsubsection{Caminhamento Elétrico}

A técnica de caminhamento elétrico consiste em investigar a variação lateral de resistividade a profundidades aproximadamente constantes. Isso é obtido fixando-se um espaçamento de eletrodos e caminhando-se com os mesmos ao longo de perfis efetuando as medidas de resistividade aparente.

Neste trabalho foi utilizado o arranjo dipolo-dipolo, cuja configuração consiste em dois eletrodos de transmissão de corrente $A$ e $B$ e dois eletrodos de medida de potencial $\mathrm{M}$ e $\mathrm{N}$ dispostos em um mesmo alinhamento (Figura 5). Faz-se o levantamento de um perfil com profundidade constante movendo-se o quadripolo ABMN a cada medida efetuada, sendo este deslocamento igual a I (distância entre as medianas dos dois pares de eletrodos) (Orellana, 1972).

Para o arranjo em questão a profundidade de penetração ou investigação obtida com o programa de inversão é da ordem de $21 \%$ da abertura máxima dos eletrodos (A-N), já que o software se utiliza do algoritmo baseado no trabalho de Edwards (1977). 
A cada ponto de medida os dipolos são deslocados de uma distância igual a $X$, os dados obtidos são plotados nas posições $n=1,2,3,4$ e 5 e interpolados, gerando uma pseudo-seção de resistividade aparente.

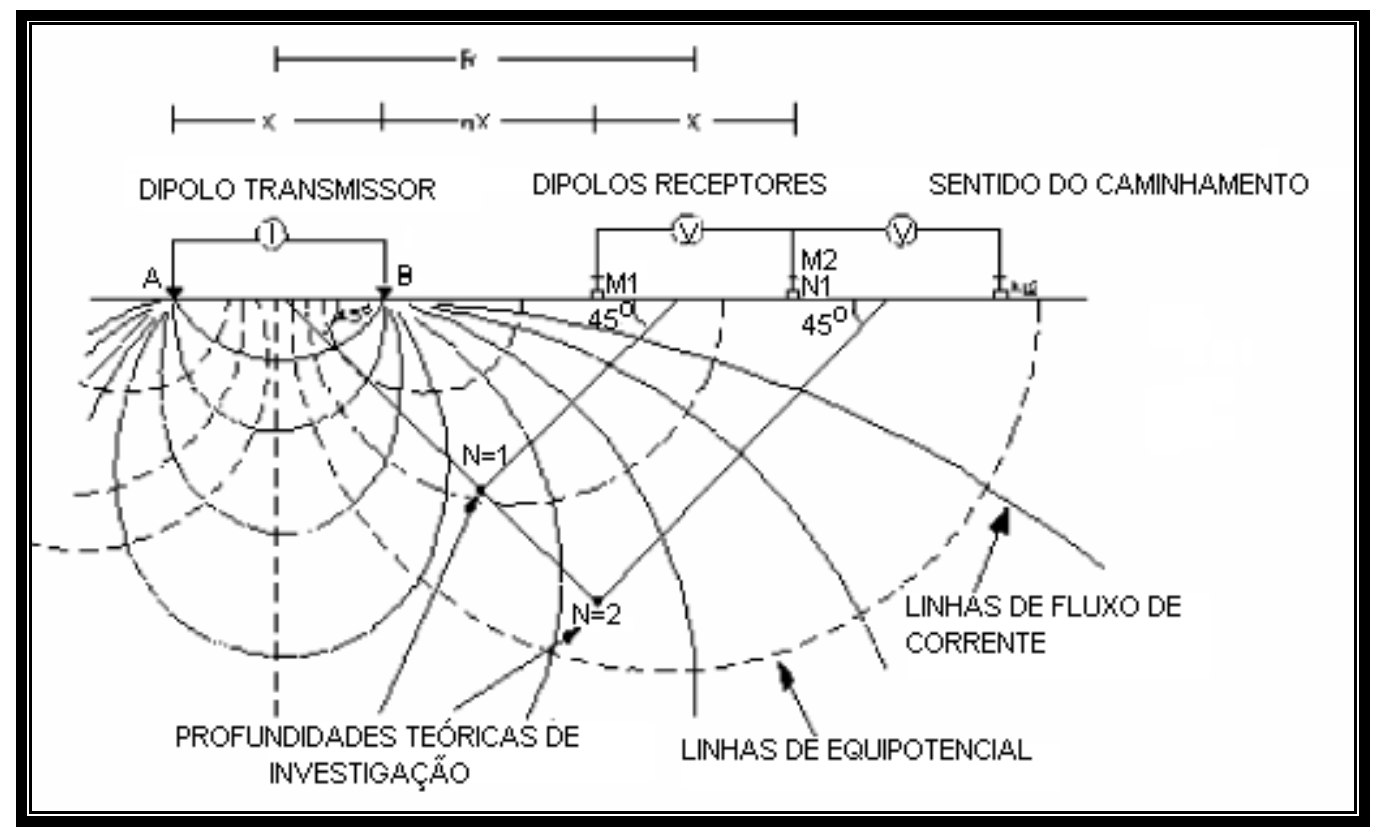

Figura 5 - Arranjo dipolo-dipolo (adaptado de Gallas et al, 2001).

Deste modo, o caminhamento elétrico (CE) busca em campo identificar estruturas verticais ou subverticais, uma vez que consiste na medição de contrastes de eletrorresistividade ao longo de uma seção. O objetivo, com base nos levantamentos periódicos durante o projeto, foi acompanhar lateralmente a migração da anomalia causada pelo acréscimo de íons gerados pela degradação dos corpos de animais enterrados.

Foram realizados perfis de caminhamento com abertura dipolo-dipolo de $1 \mathrm{~m}, 2 \mathrm{~m}$ e 4m e uma extensão aproximada de 45 metros em perfil, em 10 níveis de investigação.

Nas pseudo-seções obtidas deve-se observar as variações de resistividade aparente para uma ou mais profundidades. Essas seções permitem uma interpretação qualitativa das variações de resistividade. 


\subsubsection{Sondagem Elétrica Vertical}

A finalidade da Sondagem Elétrica Vertical (SEV) é a determinação da distribuição vertical das resistividades do subsolo abaixo do ponto estudado. Relacionando os resultados da SEV com o perfil do CE, é possível estabelecer a existência no subsolo de diferentes "camadas geoelétricas" que possam representar estratos e formações geológicas (Orellana 1972).

Esta técnica geoelétrica é feita por intermédio de dois pares de eletrodos em contato galvânico com o solo, onde um dos pares é utilizado para a injeção de corrente elétrica no solo e o outro par é utilizado para se medir a diferença de potencial gerada pelo fluxo de corrente.

A relação entre o valor da corrente e a diferença de potencial gerada permite calcular a resistividade aparente do material em subsolo. $O$ arranjo eletródico normalmente utilizado para a execução da SEV é o Schlumberger, ilustrado na Figura 6.

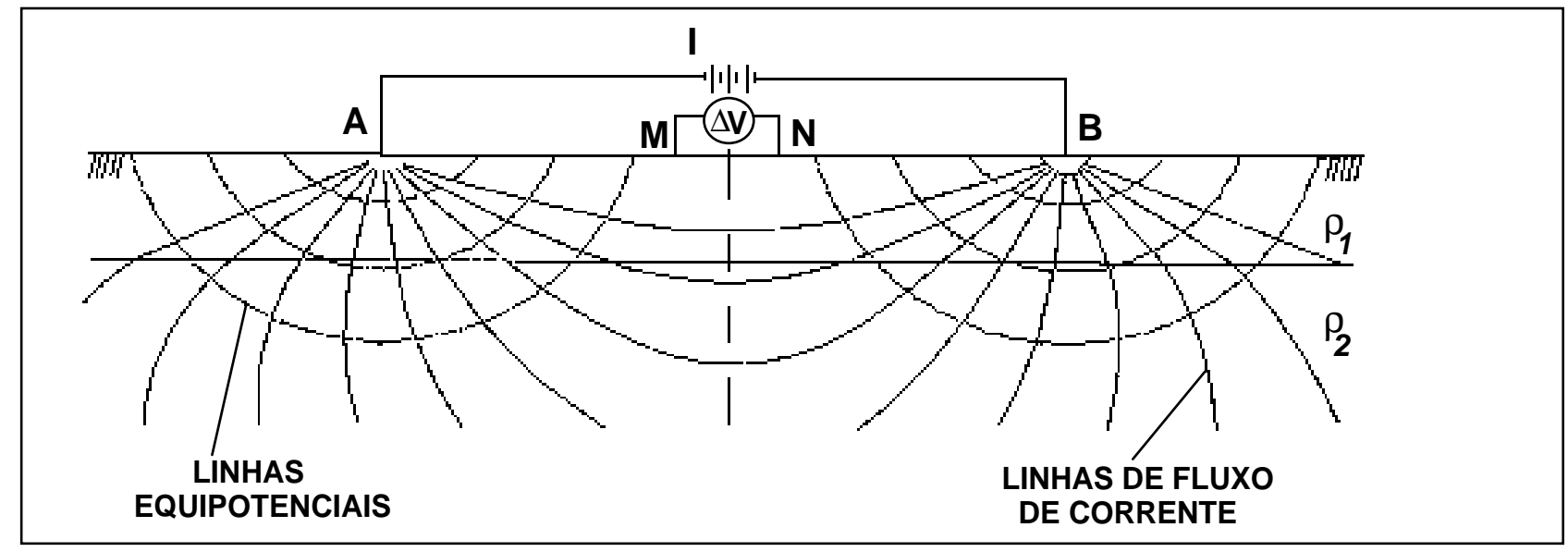

Figura 6 - Croqui de disposição dos eletrodos no terreno para aplicação do arranjo Schlumberger (Gallas, 2000).

Aumentando-se a distância entre os eletrodos de corrente $\mathbf{A}$ e B, o volume total da subsuperfície incluída na medida também aumenta, permitindo alcançar camadas cada vez mais profundas.

Os dados de resistividade aparente, obtidos em cada SEV, são representados por meio de uma curva, de acordo com as distâncias entre os eletrodos. 
Os dados de SEV são processados com a utilização de ábacos e programas automáticos de inversão.

Para a análise inicial da área escolhida foram realizadas 3 SEVs, distribuídas transversalmente à área, de forma a indicarem a variação da profundidade do aqüífero de acordo com a cota do terreno. Seus resultados serão apresentados adiante, no capítulo específico.

\subsubsection{Potencial Espontâneo}

O método geofísico denominado de Potencial Espontâneo (em inglês Self Potencial) se insere, assim como os métodos eletrorresistivos, dentro dos métodos geofísicos elétricos.

Segundo Orellana (1972), o método se baseia em que, mesmo na ausência total de qualquer campo elétrico criado artificialmente, é possível medir uma diferença de potencial entre dois eletrodos introduzidos no terreno.

De acordo com Telford et al (1990), o fator de controle, em todos os casos, é a água subsuperficial. Esses potenciais são associados com alteração de corpos de sulfetos, variações nas propriedades das rochas (conteúdo mineral) em contatos geológicos, atividade bioelétrica em material orgânico, corrosão, gradientes termais e de pressão em fluidos subterrâneos, e outros fenômenos de natureza similar.

No caso de estudo de contaminação, grandes variações dos valores de potencial espontâneo refletem condições de atividade geoquímica, sendo que em aterros sanitários podem ser observadas variações nos valores de várias centenas de milivolts. Dessa forma, em casos específicos, os ensaios de SP podem indicar se existe movimento de fluidos dos resíduos para o meio físico.

Deixando de lado a aplicação do método para prospecção mineral, podemos nos ater ao estudo dos potenciais de fluxo (streaming potential), de grande interesse em geologia de engenharia, hidrogeologia e nas questões ambientais. Gallas (2000) explica que este fluxo, também chamado de eletrofiltração ou eletrocinese é devido ao movimento de fluidos através dos poros e descontinuidades das rochas. É muito utilizado para determinação dos movimentos de água em subsuperfície, uma vez que o fluxo dos íons 
presentes nestas águas gera anomalias detectáveis pelo método, sendo possível localizar e delinear estes fluxos e as fontes associadas.

A magnitude do SP depende basicamente das características do meio e dos fluidos percolantes, tais como a resistividade elétrica, a constante dielétrica e viscosidade do fluido, continuidade do contato entre este fluido e o meio e as diferenças de pressão no percurso do fluido em subsolo.

Segundo Orellana (1972), dois tipos de eletrofiltração são conhecidos: "per ascencum" e "per descensum". Este último (Figura 7) corresponde à infiltração de água através de terrenos permeáveis ou ao longo de fraturas/falhas nas rochas. Como a água tende a arrastar os íons positivos, aparecem anomalias negativas nos locais pouco saturados e anomalias positivas nos locais saturados.

Os equipamentos utilizados são bastante simples, consistindo de eletrodos de um metal mergulhado em solução saturada de um sal do próprio metal, no caso de cobre mergulhado em CuSO4 e um multímetro, além dos cabos condutores com bom isolamento. Os resultados tanto podem ser apresentados na forma de mapas como de perfis.

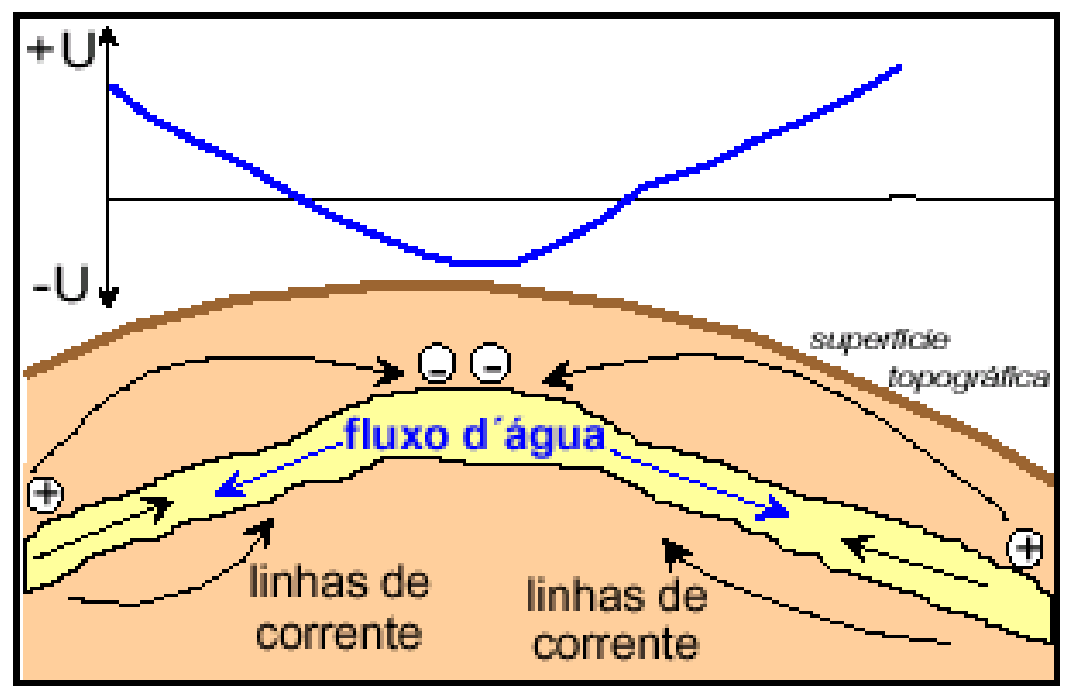

Figura 7 - Potenciais de fluxo, fenômeno "per descensum". Fonte Braga (2001) modificado.

Para este levantamento foi utilizada a Técnica dos Potenciais ou Base Fixa, com um eletrodo mantido fixo em uma estação-base (Foto 5), enquanto outro percorreu os 
pontos de medida, coincidentes com as linhas de caminhamento elétrico executadas. Esta técnica foi escolhida pela diminuição do erro cumulativo e pela agilidade do levantamento.

Para se corrigir os ruídos presentes no levantamento, especialmente a variação do SP com o tempo, foram feitas medidas de SP entre os eletrodos colocados lado a lado no início e ao final dos trabalhos. Também foi mantido constante o nível da solução nos dois eletrodos ao longo do levantamento, os eletrodos foram mantidos limpos de material após cada medida e foram feitas medidas em covas molhadas, para otimizar o contato dos eletrodos com o solo.

Neste trabalho foram utilizados eletrodos fabricados pelo próprio autor junto ao CEPAS, com uso de tubo PVC marrom e, como elemento poroso parte de piso cerâmico colado internamente e com a porção vitrificada lixada, permitindo bom contato da solução com o solo.

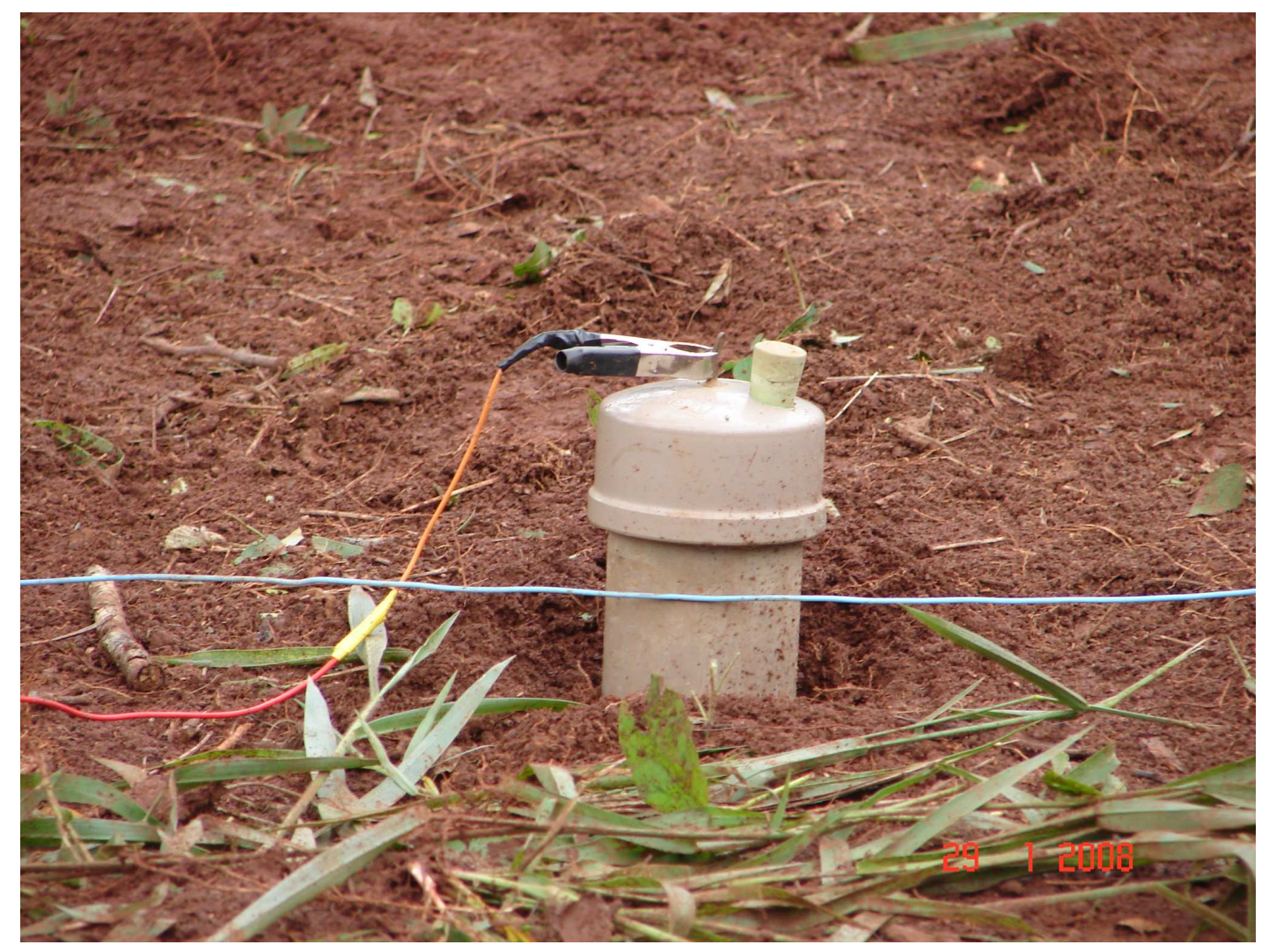

Foto 5 - Eletrodo da estação base na área da pesquisa. 


\section{Materiais e Métodos}

Para o desenvolvimento da pesquisa foram efetuadas atividades anteriores à deposição dos corpos que incluíram a escolha de uma área apropriada ao experimento até a coleta e tratamento de dados por programas específicos de alguns equipamentos utilizados.

\subsection{Escolha e Preparo da Área de Estudo}

A área de estudo foi definida dentre diversas possibilidades que se apresentaram inicialmente. Foram avaliados locais públicos ou particulares, dentro de cemitérios e áreas sem quaisquer alterações ambientais aparentes, inclusive dentro dos diversos campi da USP.

Foram eliminadas as áreas com corpos já implantados ou com histórico de alterações no local ou a montante para que se pudesse avaliar as condições ambientais e geofísicas do local escolhido antes da implantação dos corpos. Assim, excluindo-se as áreas de cemitérios, pois não possuíam áreas livres, foram mantidas as áreas sem qualquer indicação de utilização pretérita que pudesse ter alterado as condições do subsolo e das águas subterrâneas.

A escolha foi reduzida a três áreas, sendo uma no campus de Piracicaba e duas no campus de Pirassununga, pois, além destas áreas se mostrarem adequadas pela infraestrutura, considerou-se também a declividade adequada e provável profundidade rasa do aqüífero freático.

As áreas foram analisadas preliminarmente no que concerne à possível presença de alterações ou contaminações do subsolo, litologia e checagem da profundidade do aqüífero freático, através da execução de sondagem a trado manual e investigação geofísica preliminar.

A condição essencial para que a área fosse considerada adequada seria a pouca profundidade do aqüífero freático, de forma a possibilitar a instalação de poços de monitoramento a um custo pouco elevado e facilitando ainda a coleta de amostras de água.

Com esta característica também se buscava assegurar que as substâncias oriundas da decomposição atingissem o aquífero freático em tempo compatível com o 
desenvolvimento de uma Tese de Doutoramento. Entretanto a profundidade do aqüífero não poderia ser tão próxima do fundo da vala a ponto de permitir seu contato permanente com os corpos enterrados, o que poderia causar sua preservação por saponificação.

Foi ainda levado em consideração a facilidade de acesso à área, segurança para o material da pesquisa e pesquisadores e, dada a opção pela investigação em um sítio controlado e sem histórico de contaminação, a provável ausência de alterações físicoquímicas da área escolhida.

A área de Piracicaba foi então eliminada por dois motivos: a grande profundidade do nível d'água, indicada por um poço do tipo cacimba próximo, superior a 10 metros, e pela alta incidência de carrapatos transmissores de febre maculosa, razão pela qual a área foi posteriormente isolada pela prefeitura do campus.

Das duas áreas no campus de Pirassununga, apesar de próximas, uma foi descartada também pela profundidade do nível do aqüífero, também acima de 10 metros, constatada por observações de campo e informações de funcionários do próprio campus. Esta área foi posteriormente sugerida e utilizada em outro projeto de pesquisa coordenado pelo Prof. Alberto Pacheco, utilizada para depósito de corpos de animais de experimentos do campus.

A área escolhida foi, então, investigada com três sondagens a trado manual (Foto 6) e execução de três Sondagens Elétricas Verticais - SEVs - que demonstraram a pouca profundidade, adequada à pesquisa, do aqüífero freático. 


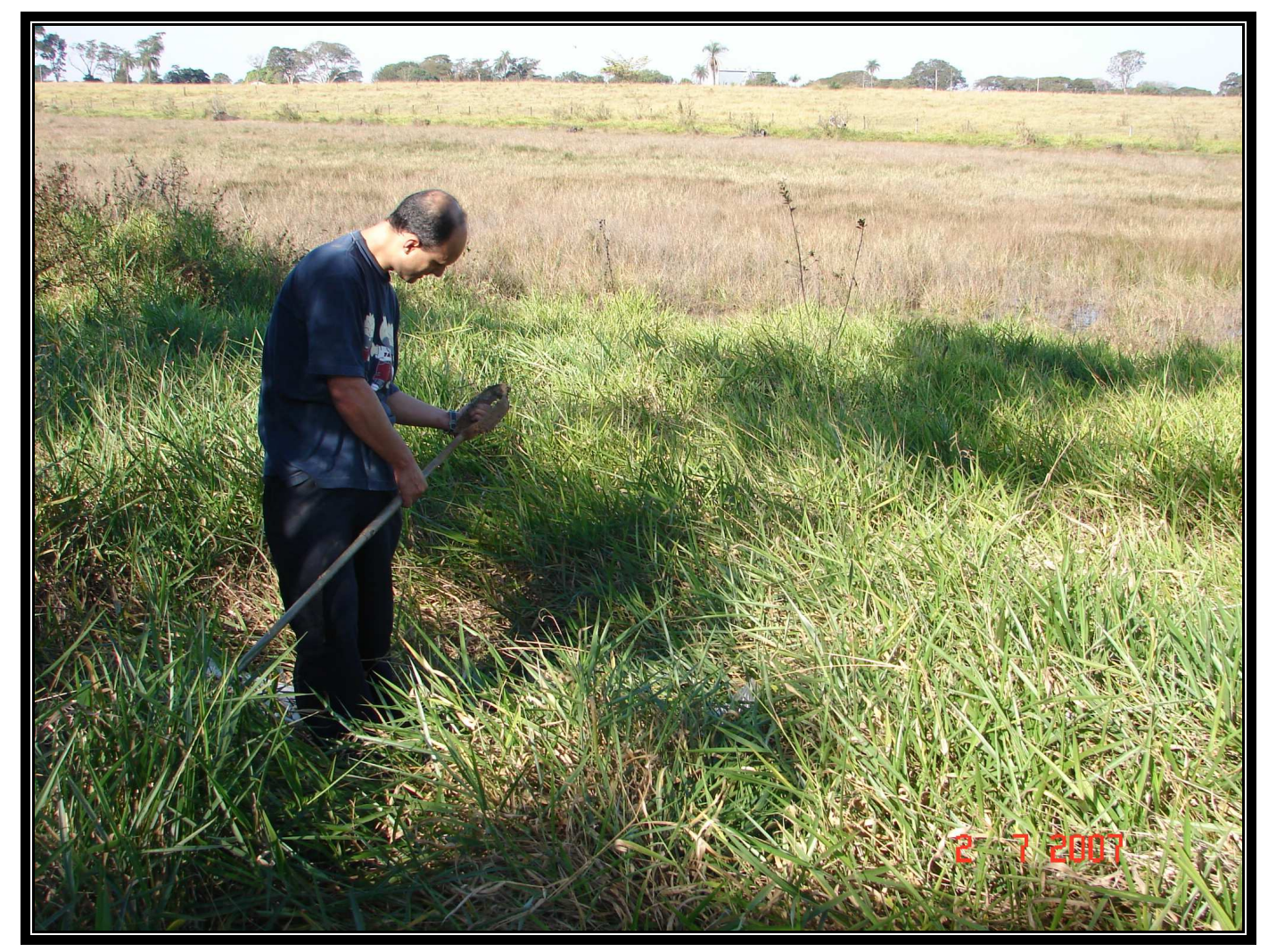

Foto 6 - Execução da sondagem a trado com a área ainda recoberta por gramíneas.

O local do experimento possui formato retangular e dimensões aproximadas de 30 x 45 metros, sendo limitada a montante por uma estrada interna do campus e a jusante por um corpo hídrico conhecido como "lagoa seca", já que possui água apenas em alguns meses do ano e, mesmo assim, apenas em anos com excesso hídrico mais volumoso. Foi executado levantamento planialtimétrico no local, sendo gerada planta georreferenciada para uso no projeto. (Figura 8).

A montante da área, após a estrada de acesso, as terras são cobertas com vegetação de grande porte, o que oferece teoricamente baixo risco de anomalias bioquímicas nas águas do freático, exceto talvez pela possibilidade de encontrarem-se coliformes provenientes das fezes dos animais silvestres ali presentes. 


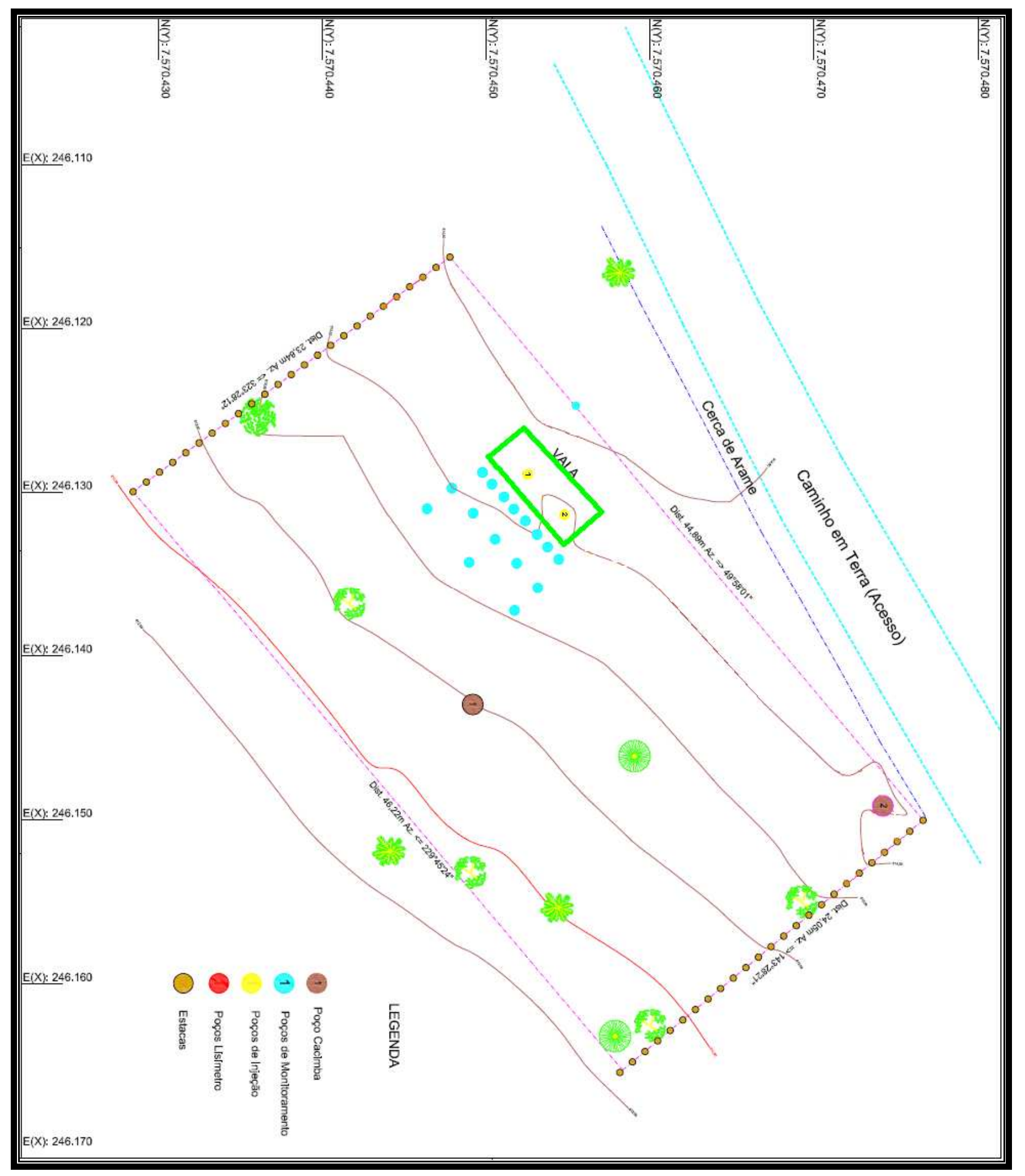

Figura 8 - Planta georreferenciada da área de pesquisa. Elipsóide: SAD 69. 
Entretanto, caso a área de montante fosse utilizada para atividade agrícola ou pastagem o risco de contaminação certamente seria maior. De qualquer maneira a presença de coliformes na água não foi utilizada nesta pesquisa como parâmetro.

A área possui apenas poucos exemplares de árvores, que não atrapalharam em demasia a pesquisa, apenas na mudança de local dos cabos no caminhamento elétrico, sendo mantidos por acordo com a coordenadoria daquele campus e para não se ferir a legislação vigente. O restante da vegetação, rasteira, foi retirado (Foto 7) para dar maior mobilidade aos equipamentos e maior segurança aos pesquisadores e técnicos envolvidos contra animais peçonhentos.

Após a conclusão dos levantamentos preliminares a área foi estaqueada em suas laterais, demarcando as linhas de levantamento que foram seguidas em todas as etapas de campo e no local da futura vala.

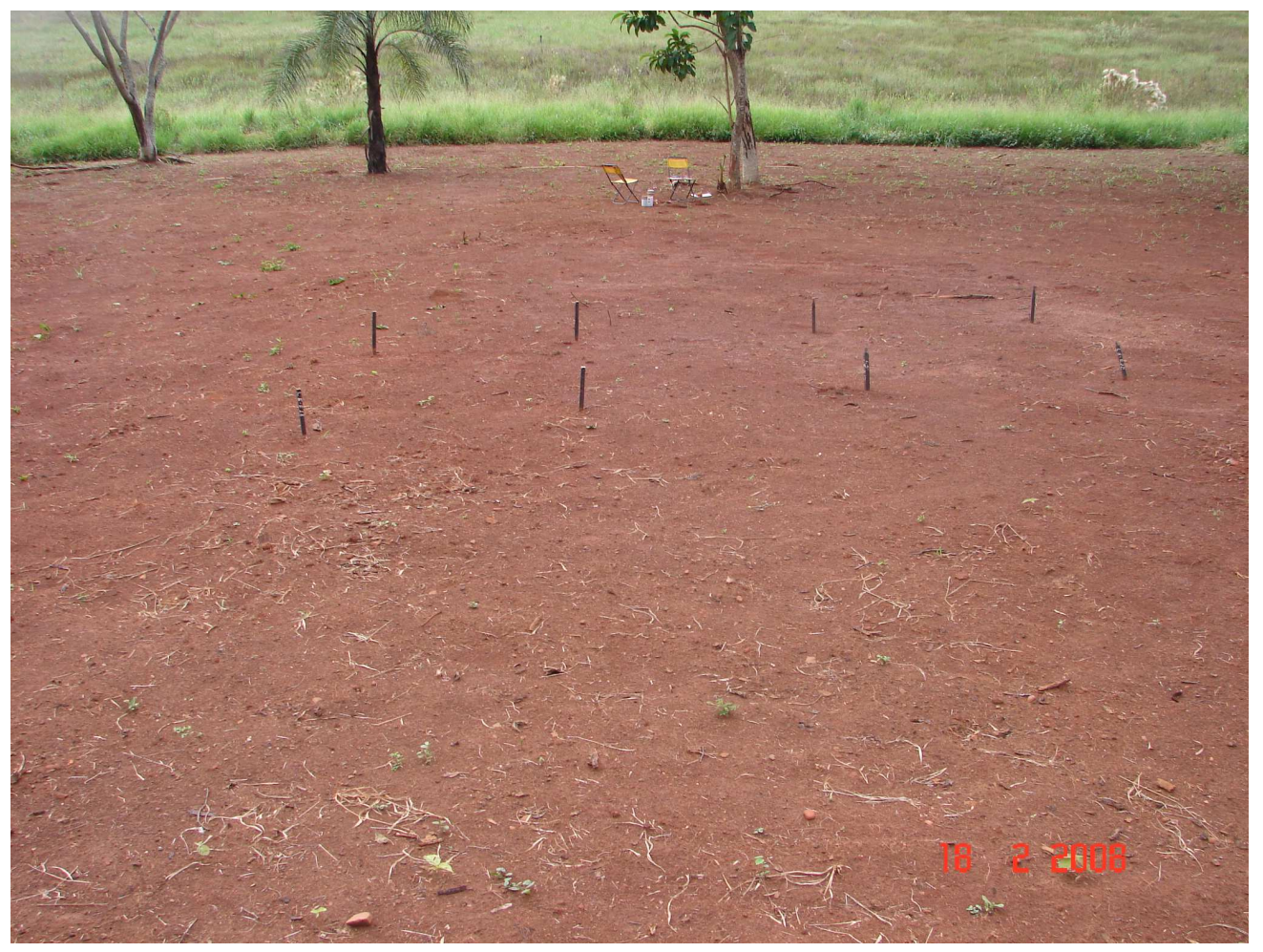

Foto 7: Detalhe da área já limpa tendo ao centro a vala demarcada. 


\subsection{Levantamentos Preliminares}

\subsubsection{Sondagem Elétrica Vertical}

As três SEVs foram localizadas ao centro da área de pesquisa, na direção estimada inicialmente como do fluxo de água subterrânea, de forma a obter dados indicativos de sua profundidade em diferentes níveis do terreno (Figura 9).

Os resultados são muito parecidos, até pela pequena distância entre os pontos levantados, e indicaram a presença do nível d'água a profundidades que variam de 2,0 m na porção mais baixa do terreno, junto à Lagoa Seca, a 4,2 m na porção mais alta, próximo ao local inicialmente definido para a instalação das valas.

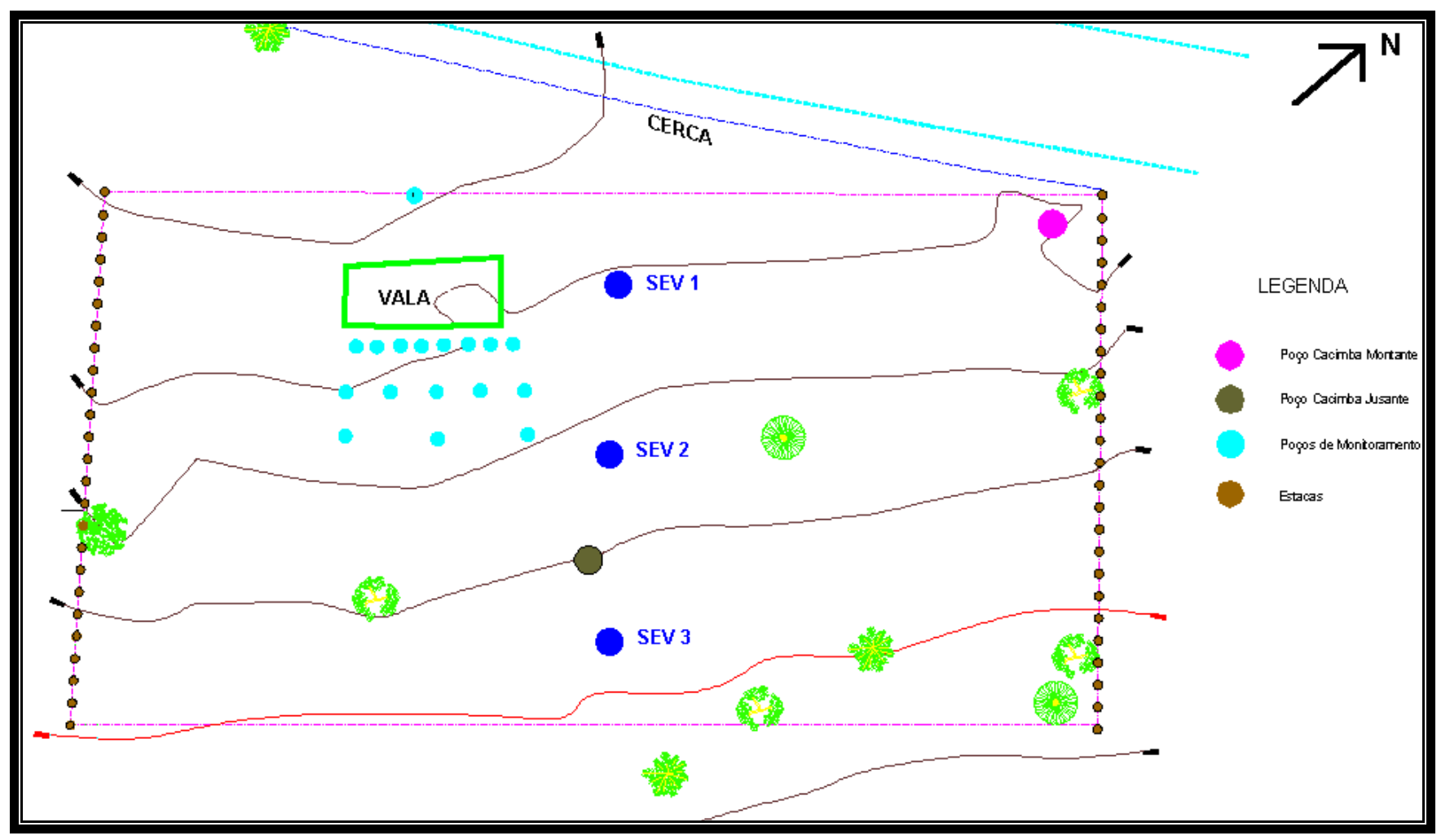

Figura 9 - Localização das SEVs efetuadas na área da pesquisa.

Na SEV-1 (Figura 10), foi interpretada a presença de três estratos geoelétricos, sendo o primeiro interpretado como o solo superficial com espessura de 0,6 m. O segundo estrato corresponde, segundo a interpretação efetuada, à camada insaturada da Formação Pirassununga, com espessura de 3,6 metros. 
A terceira camada se inicia a 4,2 $\mathrm{m}$ de profundidade, e corresponde ao topo da camada saturada, indicando a profundidade a partir da qual se devem instalar os filtros nos poços de monitoramento a serem implantados.

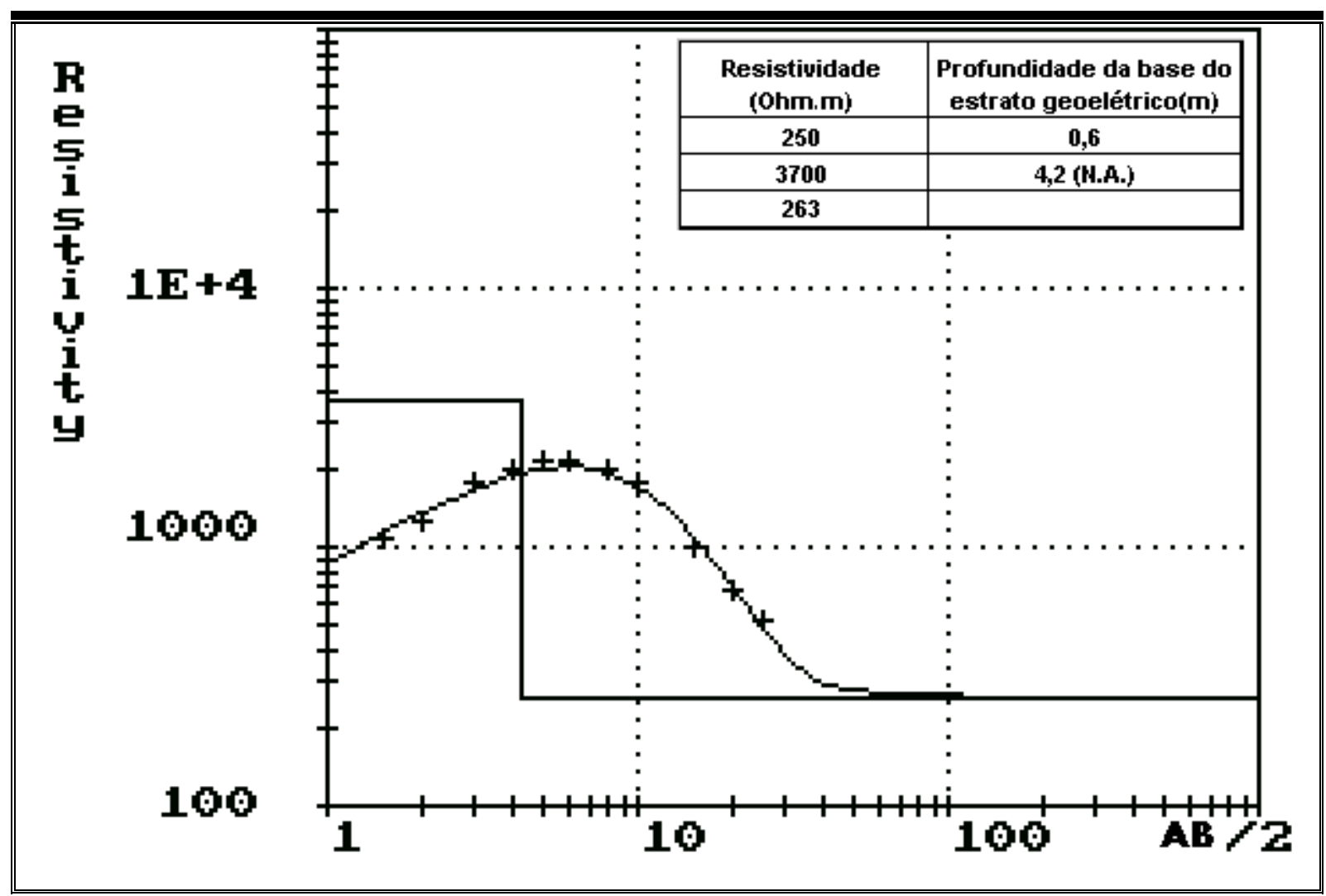

Figura 10 - Gráfico da interpretação da SEV-1.

A SEV-2 (Figura 11) efetuada na porção média da área apresenta também três estratos geoelétricos, sendo que a camada de solo superficial possui neste caso cerca de 0,5 m de espessura, a partir de onde se inicia o segundo estrato, com pouco mais de 3,1 m de espessura.

A partir da profundidade de $3,6 \mathrm{~m}$, segundo a interpretação efetuada se inicia a camada saturada com a definição do nível do aqüífero freático. 


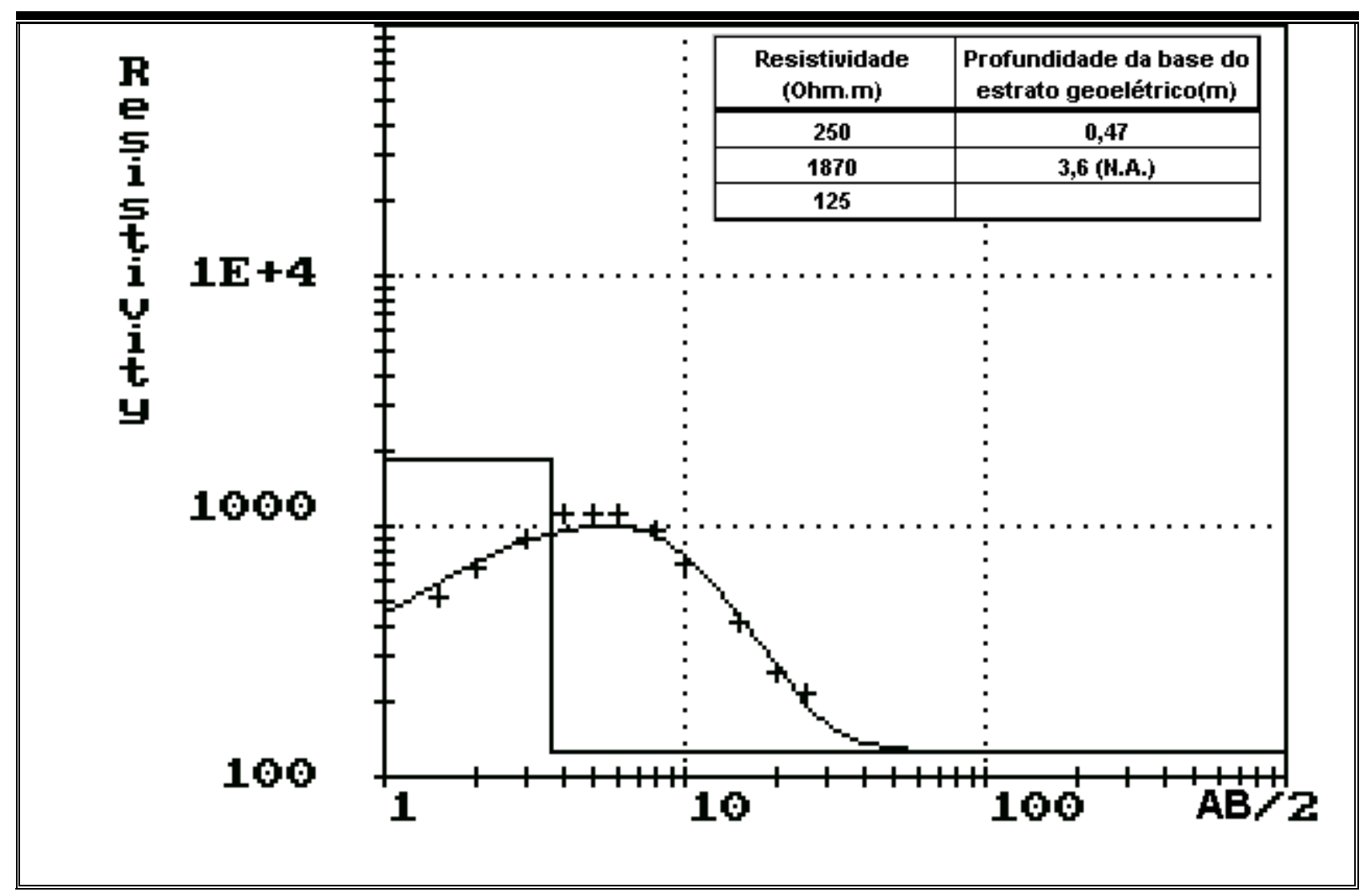

Figura 11 - Gráfico da interpretação da SEV-2.

Na SEV-3 (Figura 12) foi interpretada a presença de quatro estratos geoelétricos, com um espessamento da camada superficial de solo, condizente com sua posição mais baixa na topografia. A segunda camada, por sua vez, é menos espessa que a camada correlata das SEVs anteriores, também condizente com sua posição e com o aumento da espessura da camada superficial. O topo da camada saturada localiza-se, segundo esta interpretação, a 2,0 metros de profundidade, estendendo-se este estrato geoelétrico até a profundidade de 7,2 metros, quando se inicia novo estrato mais resistivo.

O resultado da interpretação das três SEVs permitiu planejar a profundidade dos poços de monitoramento, que deveriam ter, na porção mais elevada do terreno (poços de montante ou poços brancos) a profundidade de seis metros, sendo que dois metros na base com elemento filtrante. 


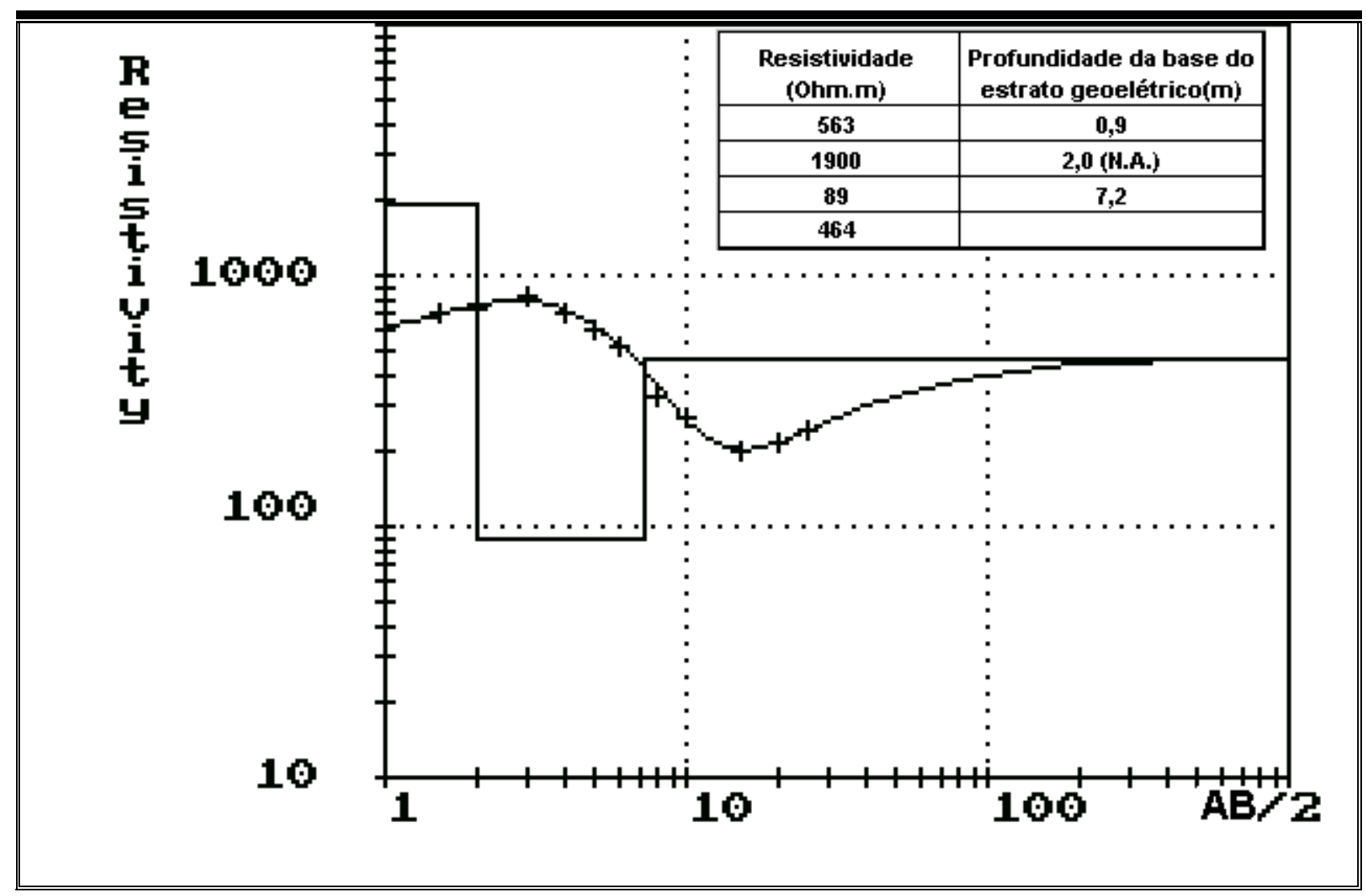

Figura 12 - Gráfico da interpretação da SEV-3.

\subsubsection{Potencial Espontâneo (SP)}

Para o método do Potencial Espontâneo foram feitos dois levantamentos visando construir um mapa potenciométrico para a área, sendo o primeiro em dezembro de 2007 com medidas a cada metro, em todas as linhas demarcadas. Posteriormente 0 levantamento foi refeito em janeiro de $2008 \mathrm{com}$ medidas a cada dois metros. Esta repetição se deu pelos resultados obtidos no primeiro levantamento que, além de apresentarem leituras de campo instáveis em determinados pontos da área, forneceu dados que indicaram direções de fluxo inversas ao esperado, ou seja, praticamente de jusante para montante e das laterais para o centro da área (Figura 13).

Os resultados do segundo levantamento (Figura 14), confirmam este resultado anômalo, sendo levantada a hipótese do fluxo subterrâneo ser subhorizontal e muito suave, com pequena variação das profundidades pela área o que, segundo a teoria 
levantada, traria movimento também suave da migração de cátions com sobreposição da variação dos resultados causada pela litologia no potencial espontâneo sobre variação causada pela direção de fluxo subterrâneo.

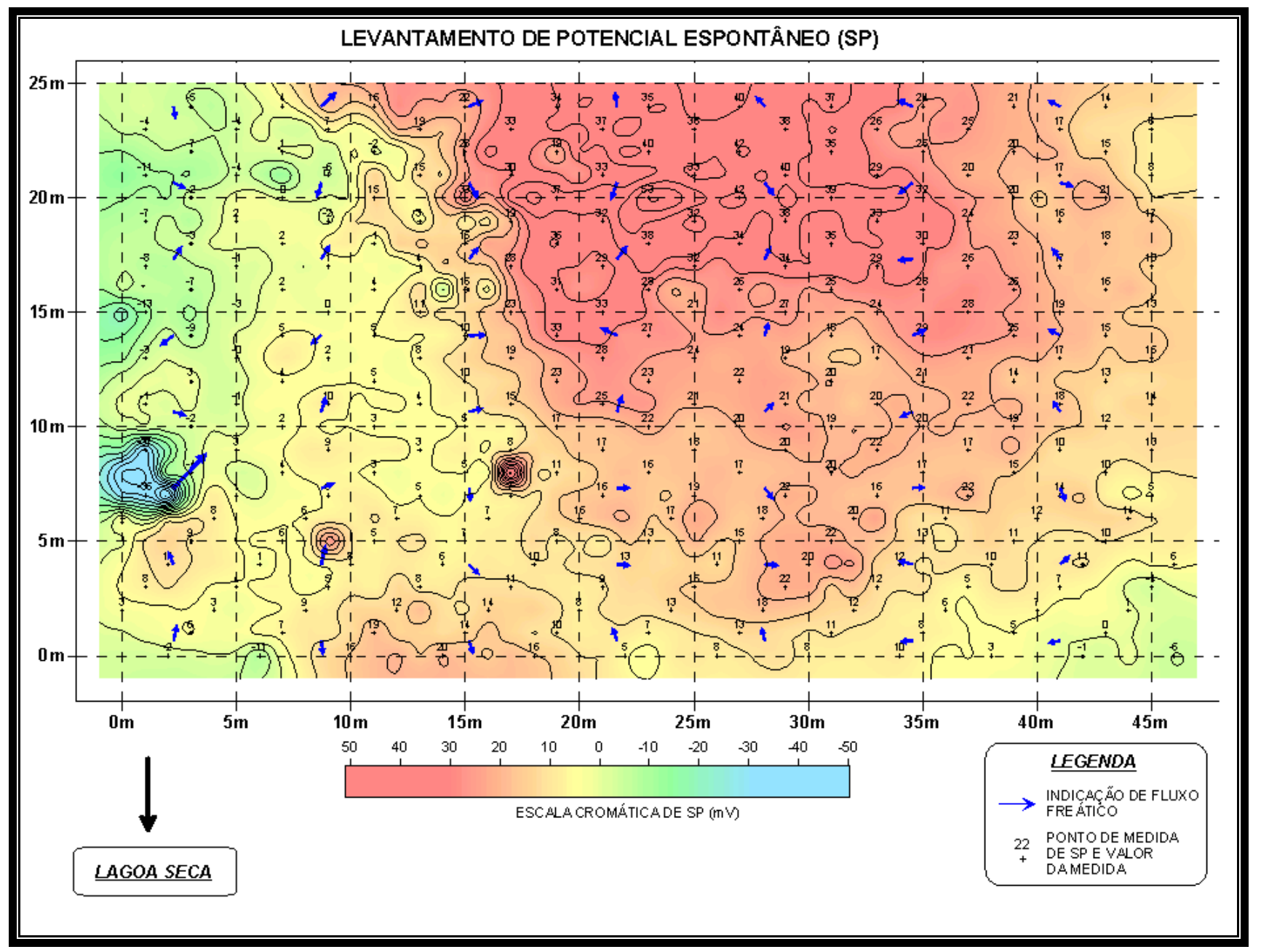

Figura 13 - Resultado do levantamento SP com medidas a cada 1m. As direções de fluxo por este levantamento indicam sentido das cores mais frias (azul e verde) para mais quentes (em laranja e vermelho). 


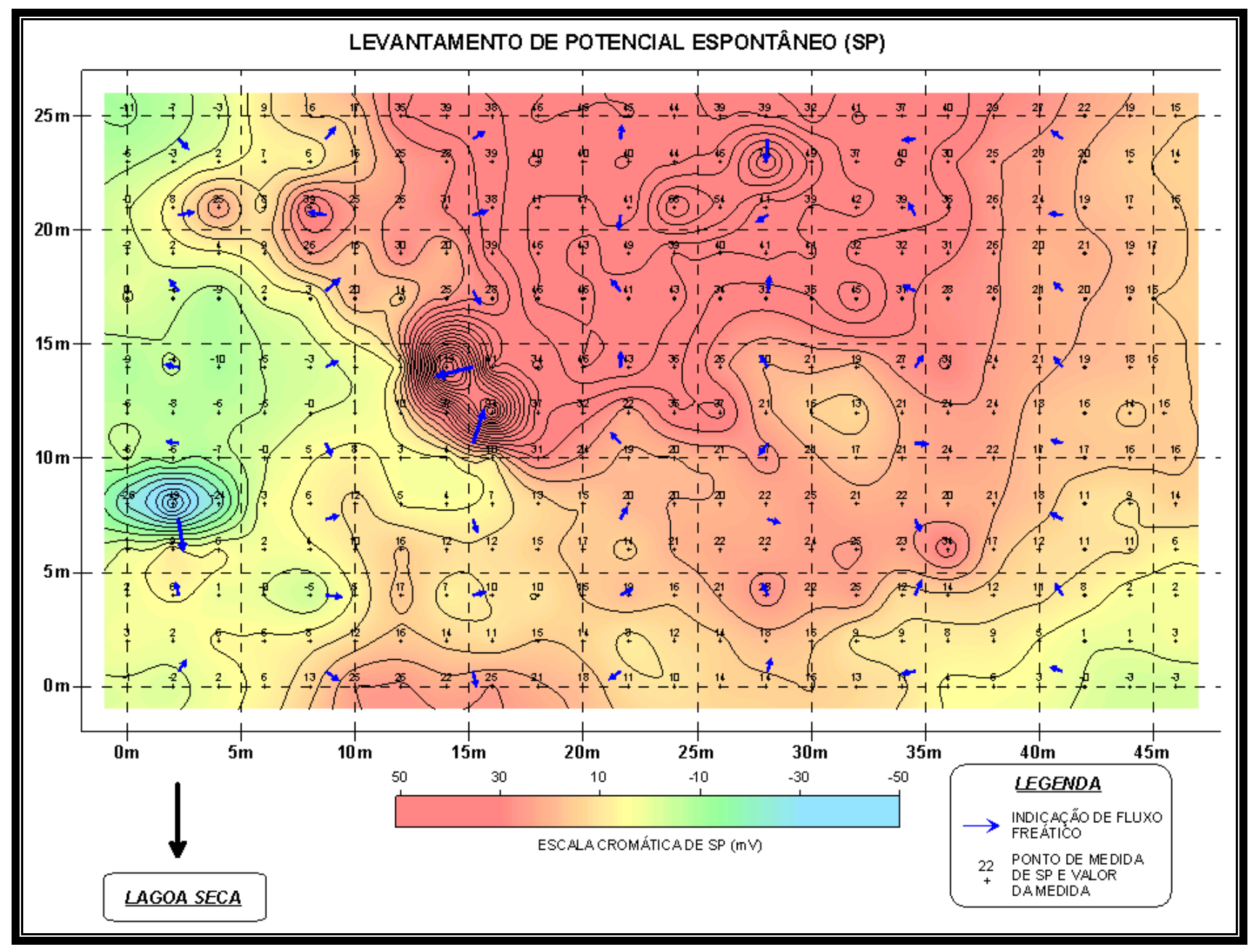

Figura 14 - Resultado do levantamento SP com medidas a cada $2 \mathrm{~m}$. As direções de fluxo por este levantamento indicam sentido das cores mais frias (azul e verde) para mais quentes (em laranja e vermelho).

\subsection{Instalacão dos pocos de Monitoramento}

A atividade seguinte na pesquisa foi a instalação dos poços de monitoramento por empresa especializada. A compactação do solo e presença de porções de rocha mais preservada em alguns pontos, especialmente na porção central da área e próximo à vala, ocasionou dificuldade na abertura dos furos de sondagem. 
Os poços foram abertos com trado de 4" de diâmetro (Foto 8) e instalados com PVC geomecânico de 2', tendo-se o cuidado de perfurar pelo menos dois metros abaixo do nível do freático de forma a evitar a falta de amostra para coleta no período de seca.

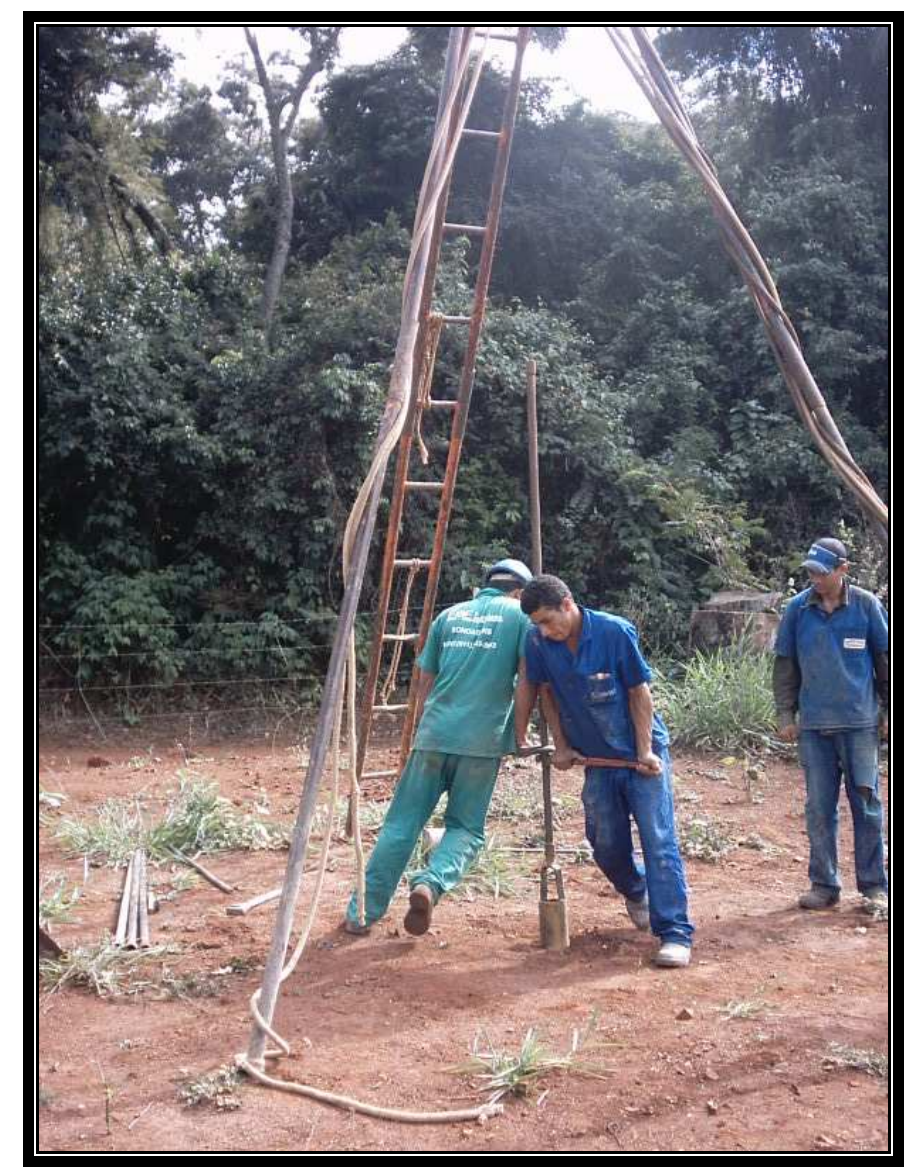

Foto 8 - Abertura de poço de monitoramento com sonda de 4 polegadas e tripé.

Em cada poço foram instalados dois metros de seção filtrante, de mesmo diâmetro do tubo dos poços (Foto 9) de forma a obter amostra com qualquer variação do freático, desconhecida até então. Procurou-se instalar a seção filtrante abaixo do nível do freático à época da instalação em junho de 2008. 


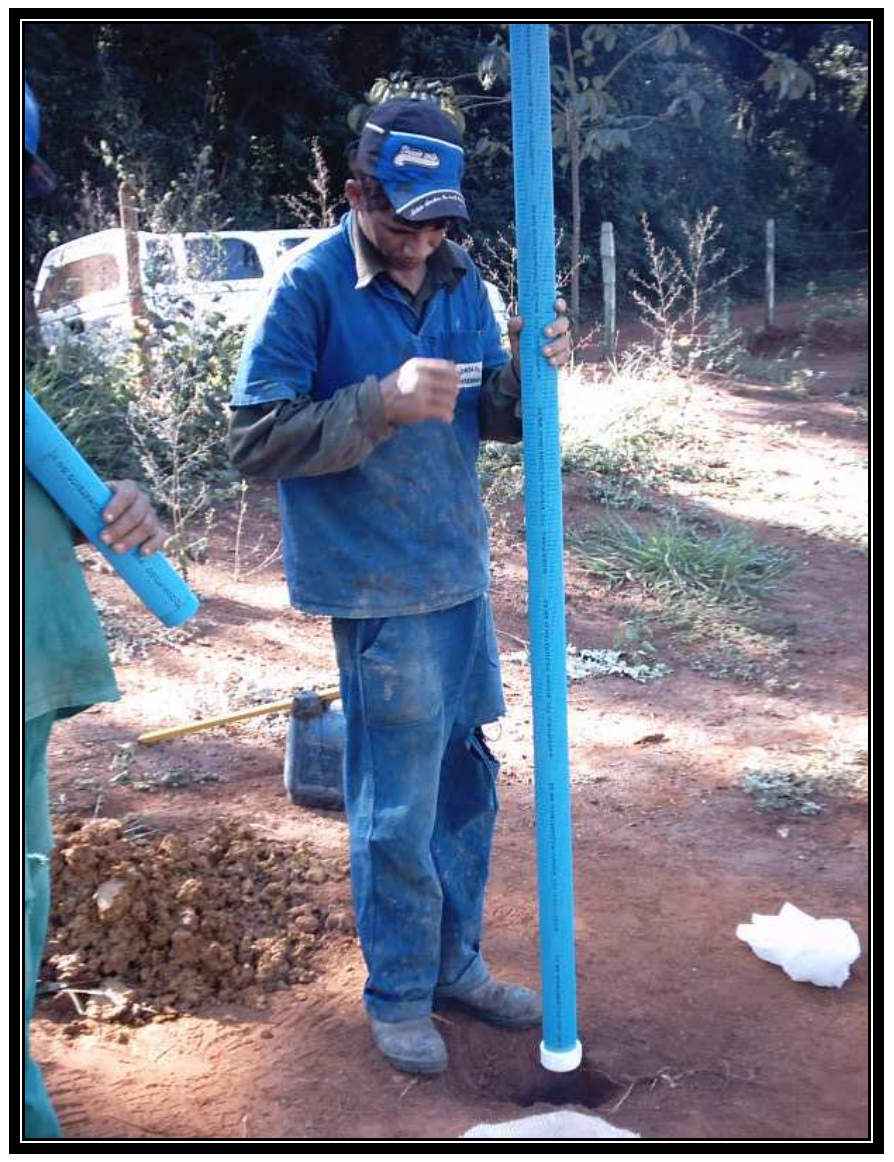

Foto 9 - Instalação do filtro no poço de montante (PM 01) em PVC ranhurado de 2 polegadas.

Imediatamente depois de colocado o tubo foi depositado material de pré-filtro, composto de areia média a grossa, lavada, até um metro acima da cota do filtro, seguido pela colocação do selo de bentonita (Foto 10), conforme as normas de instalação de poços de monitoramento e de forma a se impedir a percolação de material de camadas superiores para o pré-filtro e para o interior do poço de monitoramento.

Por fim, em cada poço foi colocado CAP rosqueável e cadeado. Para não causar interferências nos resultados dos métodos geofísicos, não foram colocadas câmaras de calçada metálicas, sendo preferido deixar o tubo acima do nível do solo. 


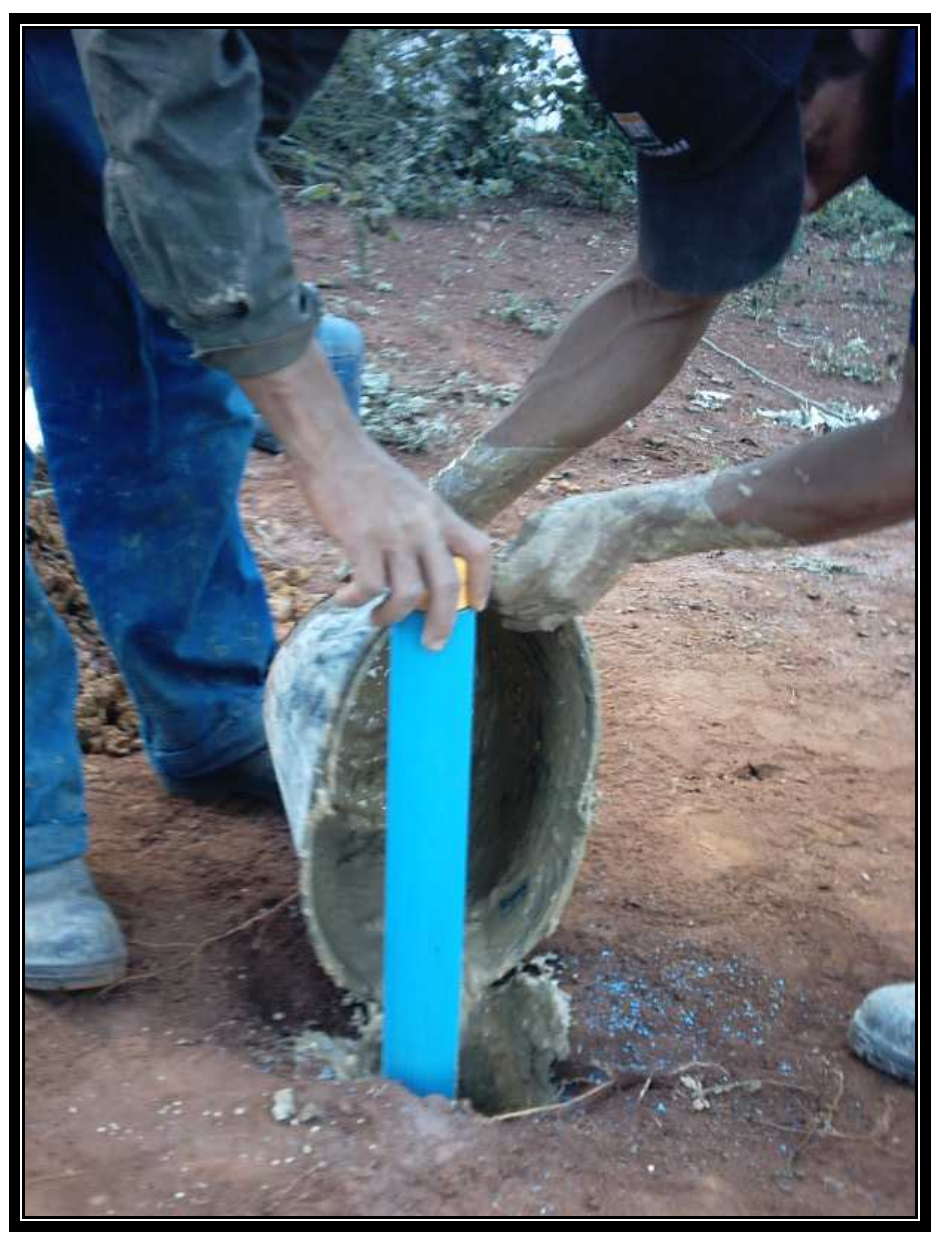

Foto 10 - Instalação do selo de bentonita.

Também pela empresa contratada e para melhor detalhar a geologia da área e o substrato onde seriam implantados os corpos dos animais, foram construídos dois poços tipo cacimba, com $1,20 \mathrm{~m}$ de diâmetro e profundidade tal que se aproximasse o máximo possível do freático, sem atingi-lo, de forma que se pudesse permanecer em seu interior (Foto 11).

Para efeito de segurança dos pesquisadores e eventual presença de pessoas ou animais no local, estes poços foram fechados com anéis de concreto em sua porção superior, coberta com tampa também de concreto (Foto 12). 


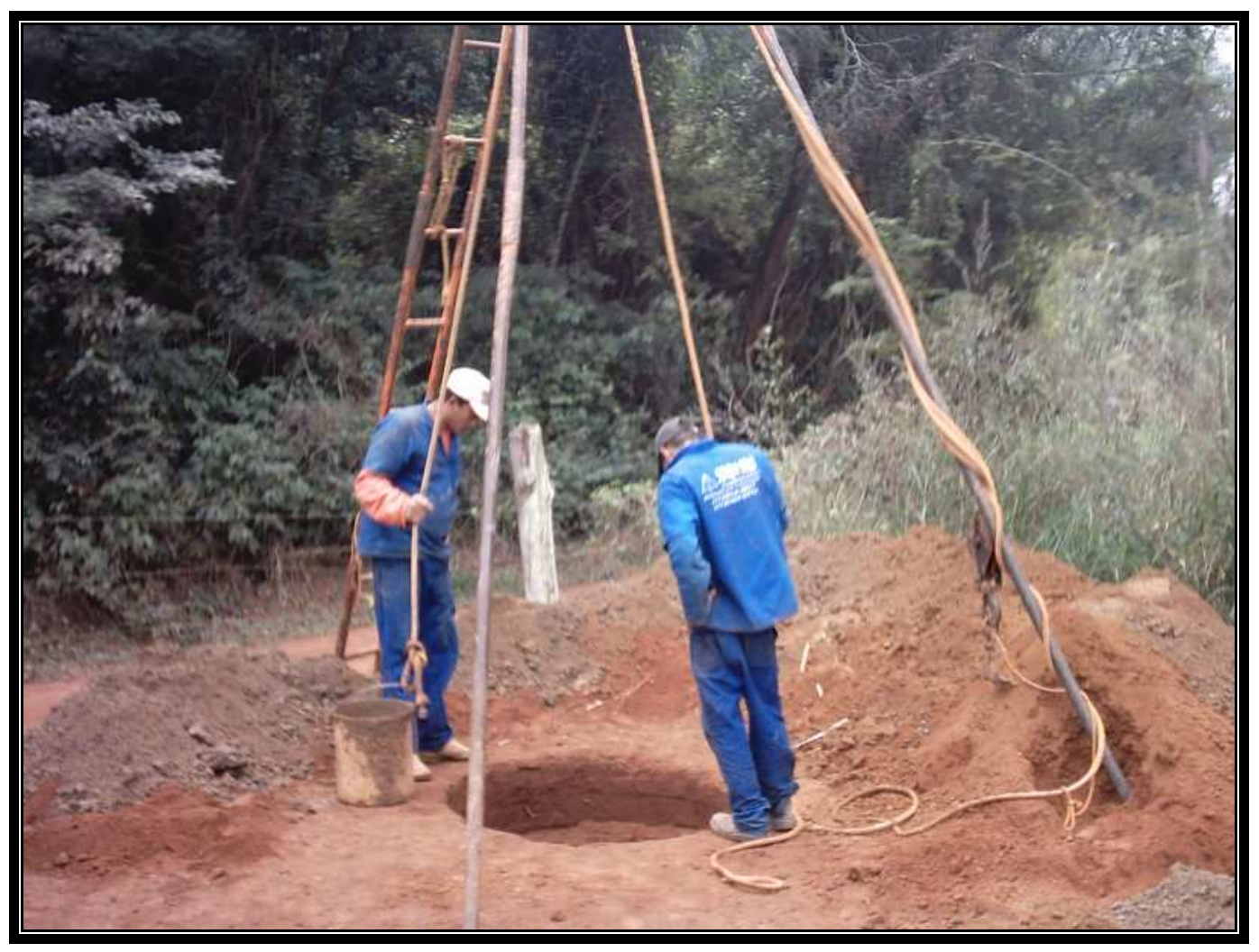

Foto 11 - Abertura do poço cacimba de montante, próximo à estrada.

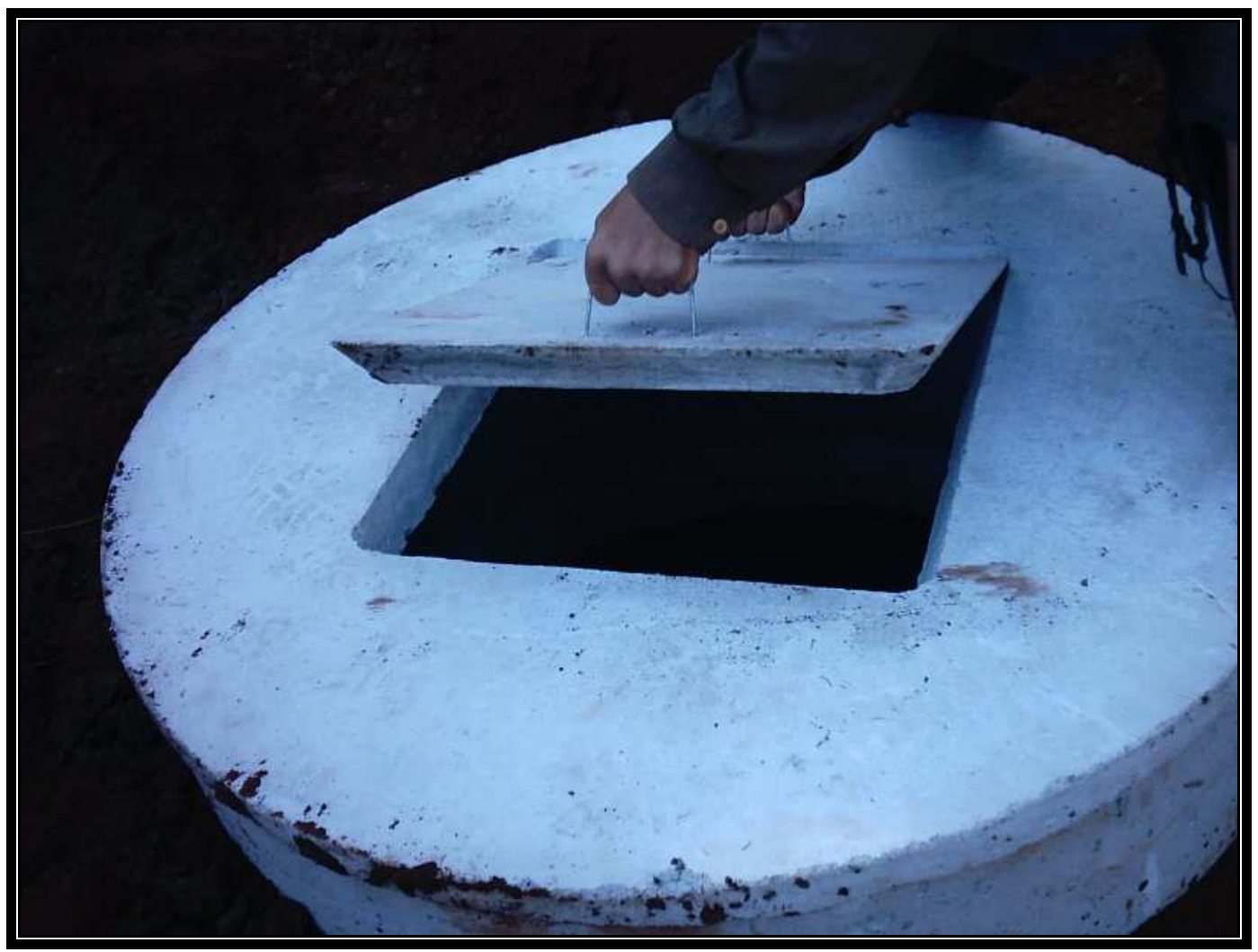

Foto 12 - Anel e tampa de concreto sobre o poço cacimba. 
Com a finalização do preparo da área em (Foto 13) pôde ser iniciada a pesquisa, com coleta de amostras de água dos poços de monitoramento e levantamentos geofísicos prévios à implantação dos corpos.

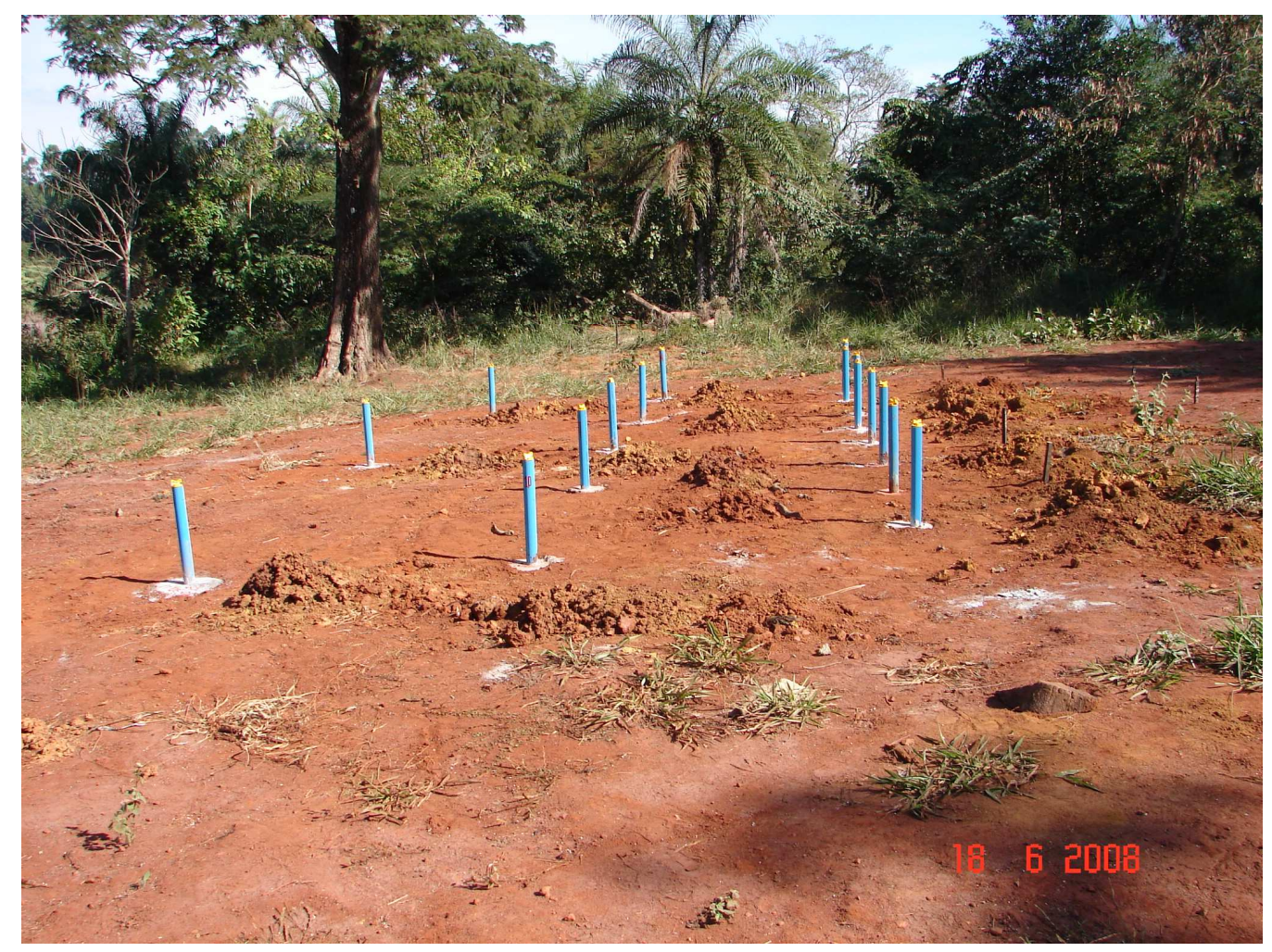

Foto 13 - Área com poços de monitoramento instalados antes da abertura da vala.

\subsection{Coleta de Amostras de Áqua}

Em todas as etapas de campo, além dos levantamentos geofísicos, também foram efetuadas coletas de amostras de água e medição do nível dos poços de monitoramento. Em relação à profundidade do nível d'água, apesar do cuidado em se perfurar os poços dois metros abaixo do nível freático, durante o maior período de estiagem alguns poços não puderam proporcionar volume suficiente para coleta, com material excessivamente argiloso que dificultaria a filtragem. Neste período um pequeno adiamento foi suficiente para a chegada das chuvas e a coleta de amostras.

A coleta de amostras foi feita com auxílio de técnico do CEPAS, seguindo-se metodologia usual deste Centro de Pesquisas e que consistiu do desenvolvimento dos poços, coleta, preservação e transporte. 
Para o desenvolvimento dos poços que consiste na troca da água estagnada em seu interior é feito o esgotamento do poço com auxílio do bailer (amostrador descartável com capacidade de 1 litro), em que se retira no mínimo três vezes o volume de água do mesmo, geralmente um dia antes da amostragem, para que o poço possa recuperar seu volume.

Para o cálculo do volume aproximado dos poços foram feitas medidas do nível d'água antes do esgotamento, a medida da profundidade do poço, bem como do diâmetro do tubo de PVC do poço e sua parte sobressalente do solo (Figura 15). Com isso pôde ser calculada a coluna d'água (h) bem como o volume (V).

$$
\mathbf{V}=\pi \cdot \mathbf{r}^{2} \cdot \mathbf{h}, \text { portanto, neste exemplo } 0,00475 \mathrm{~m}^{3} \text { ou } 4,75 \mathrm{~L}
$$

Ou seja, neste caso seria necessária a retirada de no mínimo 14,25 litros de água dos poços para esgotá-los. Porém, como a recuperação o nível da água é rápida na área em estudo, foi utilizado o valor de 18 litros para todos os poços, garantindo que a amostra é representativa do aqüífero freático naquele ponto.

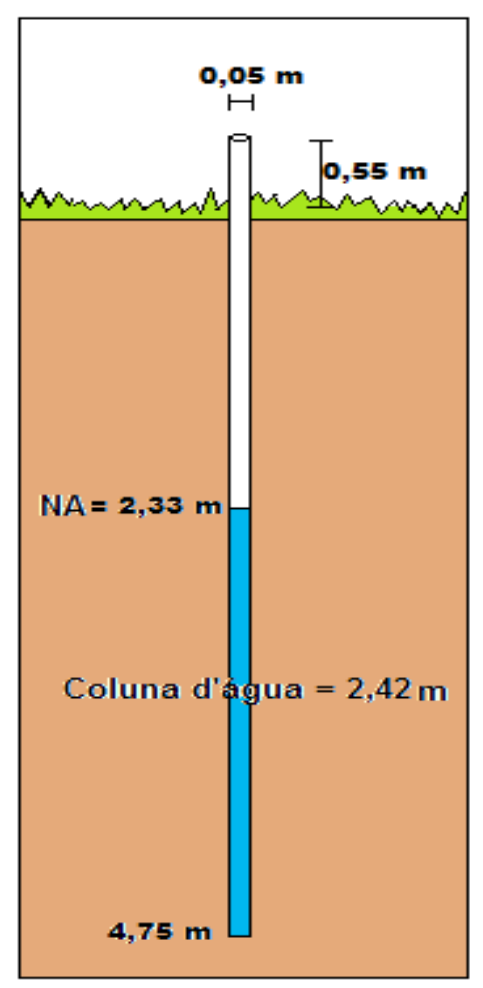

Figura 15 - Esquema para cálculo do volume de poço de monitoramento. 
As coletas foram feitas um dia após o desenvolvimento dos poços, utilizando-se luvas descartáveis para manuseio dos equipamentos. Bailers, também descartáveis, foram introduzidos suavemente nos poços para não turbilhonar a água, permanecendo o tempo necessário até seu completo preenchimento.

Retirado do poço, foi colocada a ponteira no bailer para liberação do fluxo, sendo o primeiro jato colocado no pote coletor, enxaguado e descartado. A seguir o pote foi preenchido até próximo do volume máximo, tampado, identificado e imediatamente colocado sob refrigeração para transporte ao laboratório.

Ainda em relação às campanhas de amostragem, além dos parâmetros físicoquímicos previstos, foram efetuadas duas campanhas de análise microbiológica em seis pontos, sendo cinco poços de monitoramento e um ponto na Lagoa Seca. Isto foi feito de forma a comprovar, inequivocamente, que a qualidade das águas da Lagoa Seca não foi afetada pelo experimento efetuado. Foram analisados os seguintes parâmetros:

- Coliformes Totais

- Coliformes Fecais

- Clostrídeos Sulfito Redutores

Os resultados mostram (Tabela 2) que coliformes se encontram naturalmente nas águas subterrâneas do local, possivelmente pela presença de gado e outros animais domésticos e silvestres.

Apesar do número reduzido de amostragens que impossibilita maiores conclusões, a alteração de Clostrídeos não deve estar ligada ao experimento, uma vez que a alteração desse parâmetro se deu apenas na amostra da Lagoa, mas em nenhuma amostra dos poços de monitoramento. 
Tabela 2 - Resultados das análises microbiológicas na área do experimento.

\begin{tabular}{|c|c|c|c|c|c|c|}
\hline Local & \multicolumn{2}{|c|}{$\begin{array}{c}\text { Coliformes } \\
\text { a } 35^{\circ} \mathrm{C} \\
\text { NMP/100 mL }\end{array}$} & \multicolumn{2}{c|}{$\begin{array}{c}\text { Coliformes } \\
\text { Termotolerantes } \\
\text { NMP/100 mL }\end{array}$} & \multicolumn{2}{c|}{$\begin{array}{c}\text { Clostrídeos Sulfito } \\
\text { Redutores } \\
\text { UFC } / \mathrm{mL}\end{array}$} \\
\hline & $\begin{array}{c}\text { Agosto } \\
2008\end{array}$ & Abril 2009 & $\begin{array}{c}\text { Agosto } \\
2008\end{array}$ & Abril 2009 & $\begin{array}{c}\text { Agosto } \\
2008\end{array}$ & Abril 2009 \\
\hline PM 1 & 460,0 & 3,6 & $<3,0$ & $<3,0$ & $<10,0$ & $<10,0$ \\
\hline PM 5 & $<3,0$ & 23,0 & $<3,0$ & $<3,0$ & $<10,0$ & $<10,0$ \\
\hline PM 8 & $<3,0$ & 9,2 & $<3,0$ & $<3,0$ & $<10,0$ & $<10,0$ \\
\hline PM 16 & $<3,0$ & 9,2 & $<3,0$ & $<3,0$ & $<10,0$ & $<10,0$ \\
\hline PM 17 & 9,2 & 9,2 & $<3,0$ & $<3,0$ & $<10,0$ & $<10,0$ \\
\hline Lagoa & 240,0 & 240,0 & $<3,0$ & $<3,0$ & $<10,0$ & $2,0 \times 10^{2}$ \\
\hline Seca & & & & & &
\end{tabular}

\subsection{Colocacão dos Corpos de Animais}

Em 15 de setembro de 2008 ocorreu o abate de 17 vacas de experimentos internos da FZEA / USP e o material que seria descartado pelo matadouro em aterro de resíduos do campus foram levados à área para serem depositados na vala de dimensões $3 \mathrm{~m} \times 7 \mathrm{~m}$ $x 2,5 \mathrm{~m}$, aberta anteriormente.

Além deste material, foram depositadas carcaças de frango e de coelhos utilizados em experimentos e também abatidos naquela data (Fotos 14 a 17) totalizando aproximadamente $6.000 \mathrm{~kg}$ de matéria orgânica.

Imediatamente após a colocação dos corpos, a área foi recoberta com o material retirado do próprio local e levemente compactado de forma a não diminuir a permeabilidade do solo.

Como medida extra de precaução, foram instalados drenos de injeção de água para o caso de um período de estiagem muito grande que poderia preservar os corpos por mumificação. Entretanto, estes não chegaram a ser utilizados, pois o período de chuva se iniciou logo após o enterramento, apesar de mais fraco que em anos anteriores. 


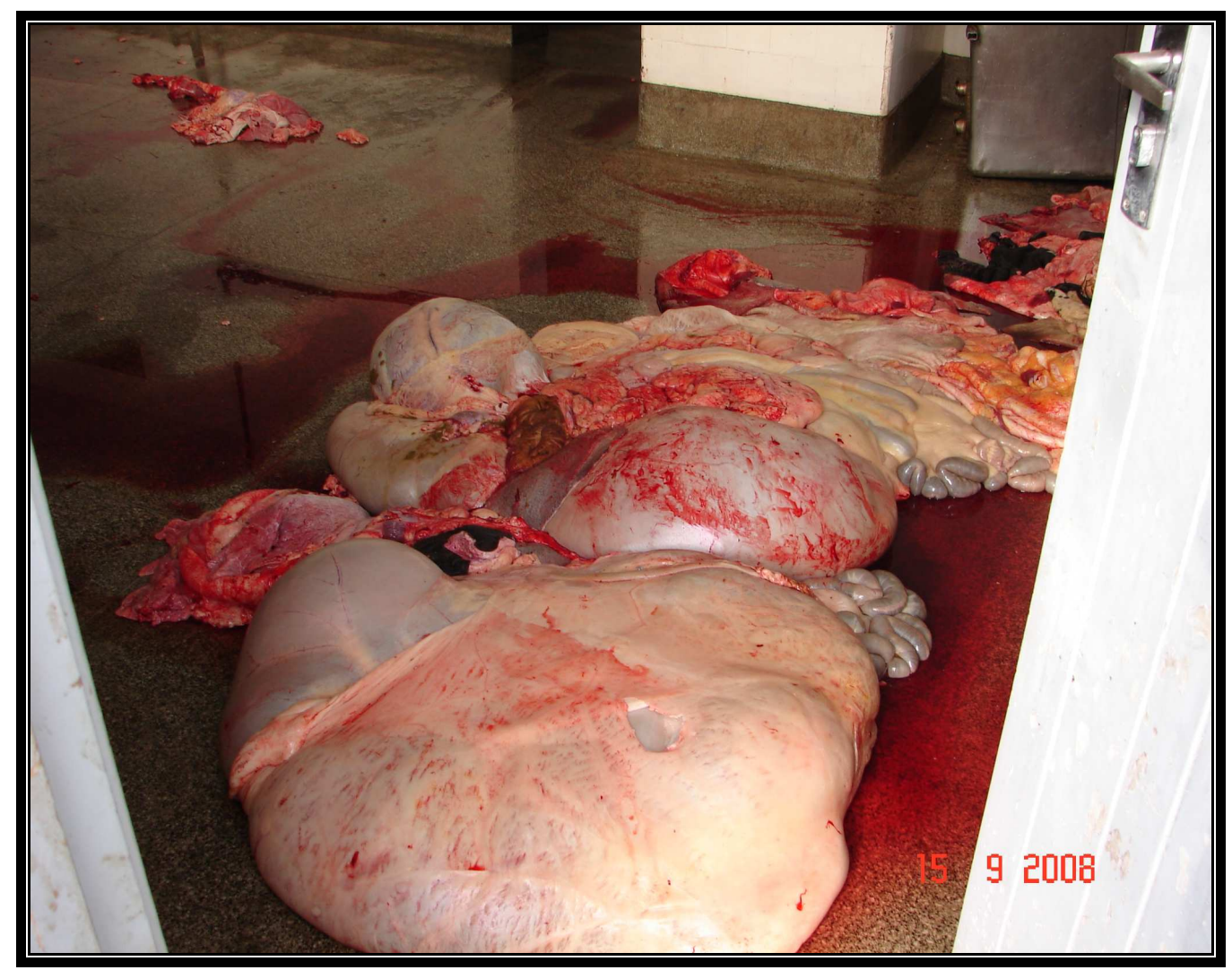

Foto 14 - Parte do material separado no abate para o experimento.

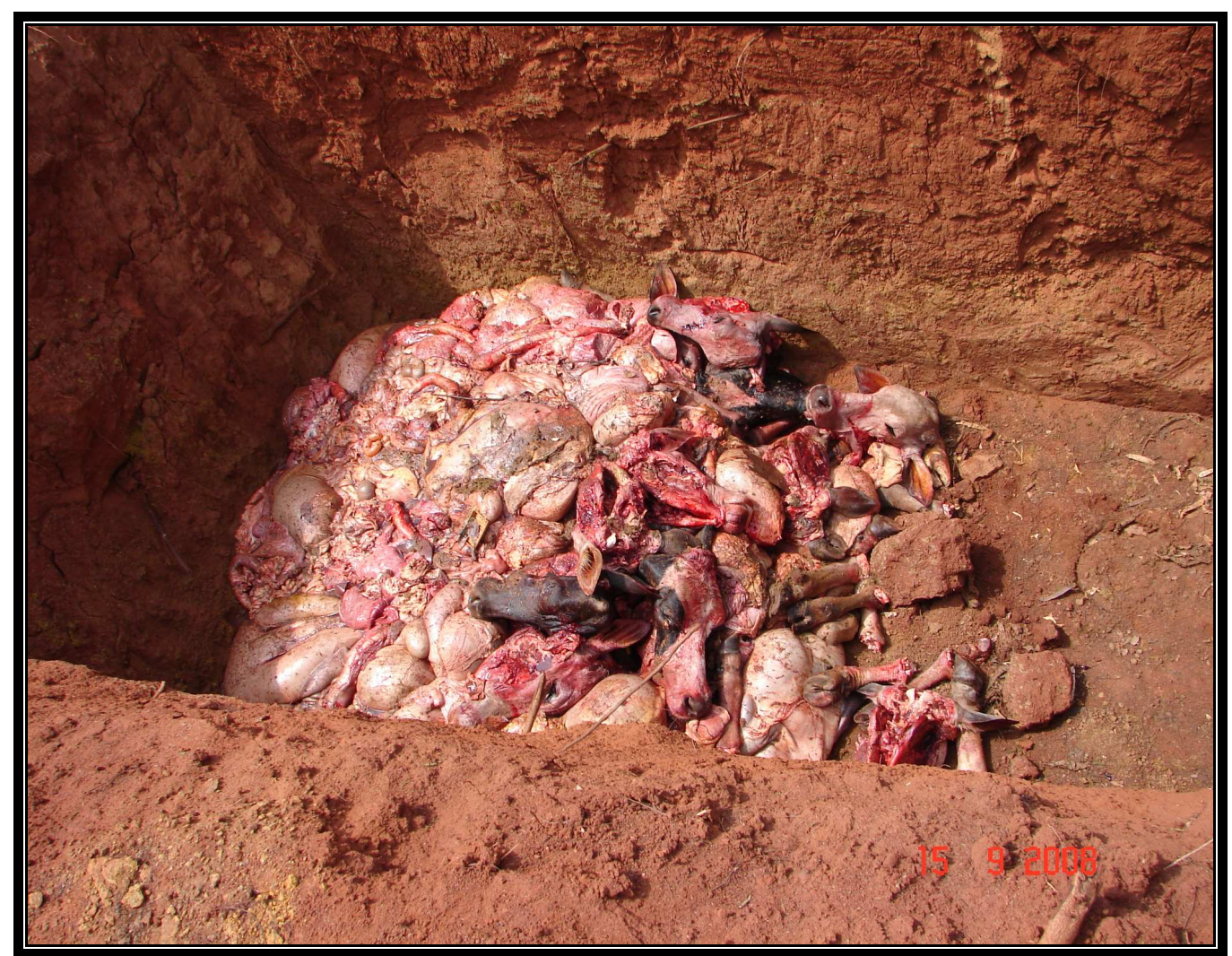

Foto 15 - Material lançado no interior da vala do experimento. 


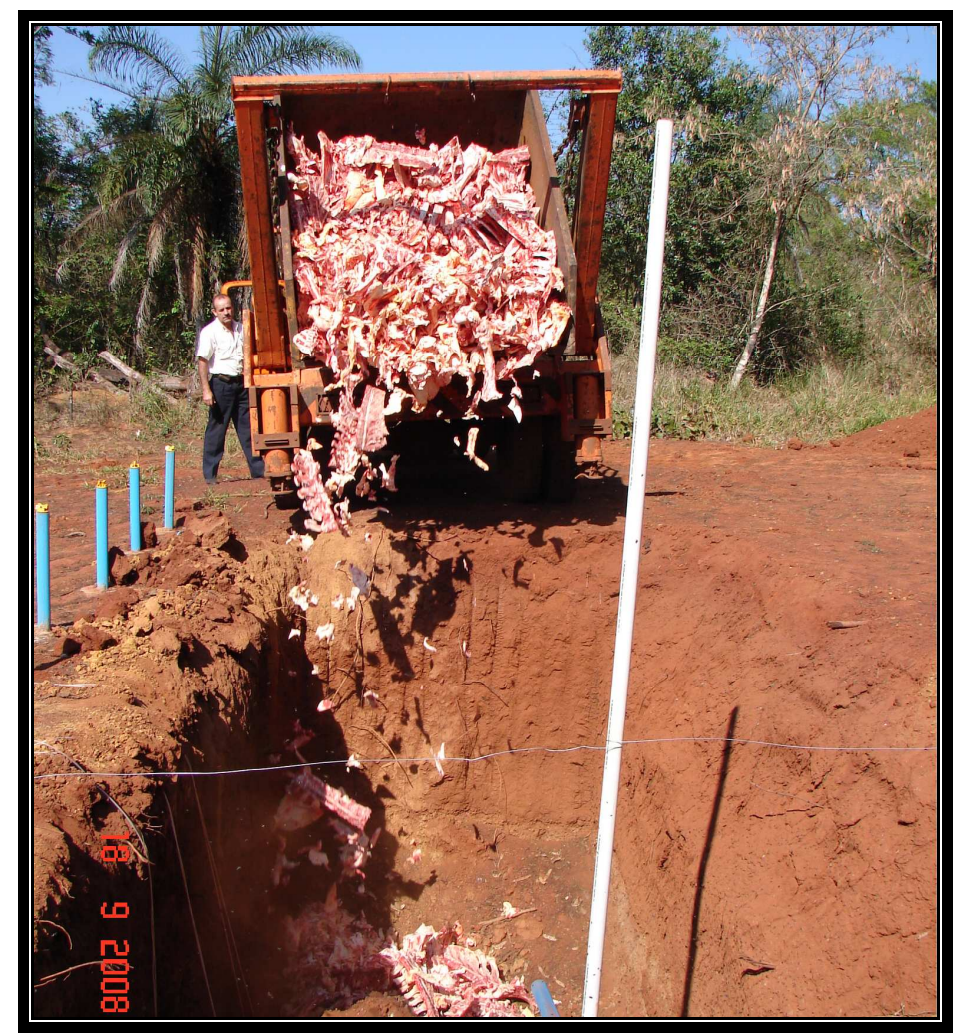

Foto 16 - Material sendo depositado na vala.

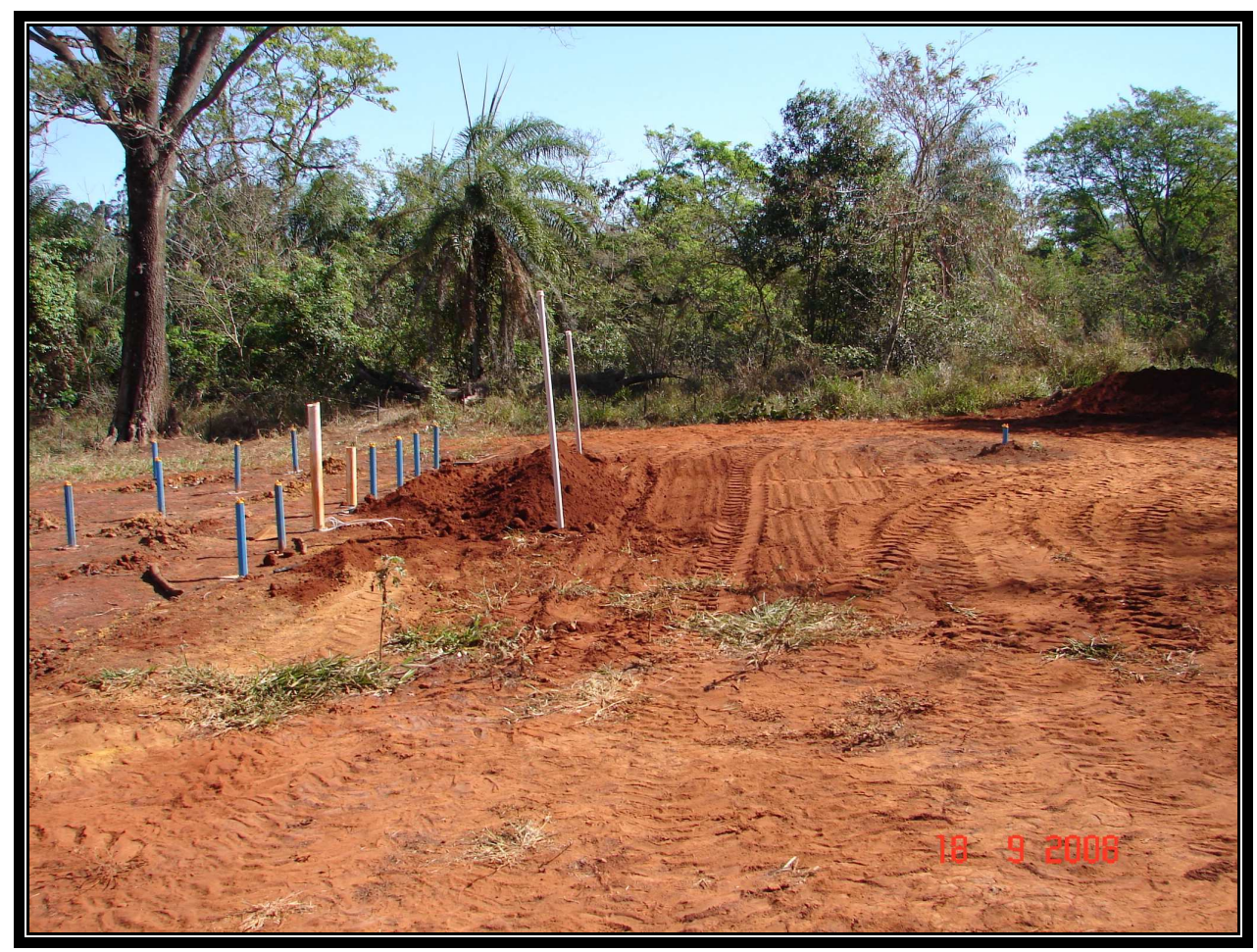

Foto 17 - Área recoberta após a implantação dos corpos. 


\subsection{Aquisicão de Dados Geofísicos}

Após a deposição dos corpos dos animais, foi iniciada a fase de levantamentos periódicos, pelos três métodos geofísicos propostos.

Para a obtenção de uma imagem fiel da situação em subsuperfície, foi definida a amostragem com densidade tal que se pudesse obter os limites ou contornos do alvo investigado.

Desta forma, foi definida a malha densa o suficiente para se obter a definição da possível pluma de contaminação (lateralmente e em profundidade) e identificação de camadas. Ficou estipulada a área de investigação dentro da área de pesquisa de medidas $25 \mathrm{~m} \times 45 \mathrm{~m}$.

Os levantamentos foram feitos sobre as linhas (Figura 16), sempre no mesmo sentido, iniciando-se nas estacas ao lado oeste da área, tomando-se o cuidado de seguir sobre as linhas utilizando-se para isso trenas como guias.

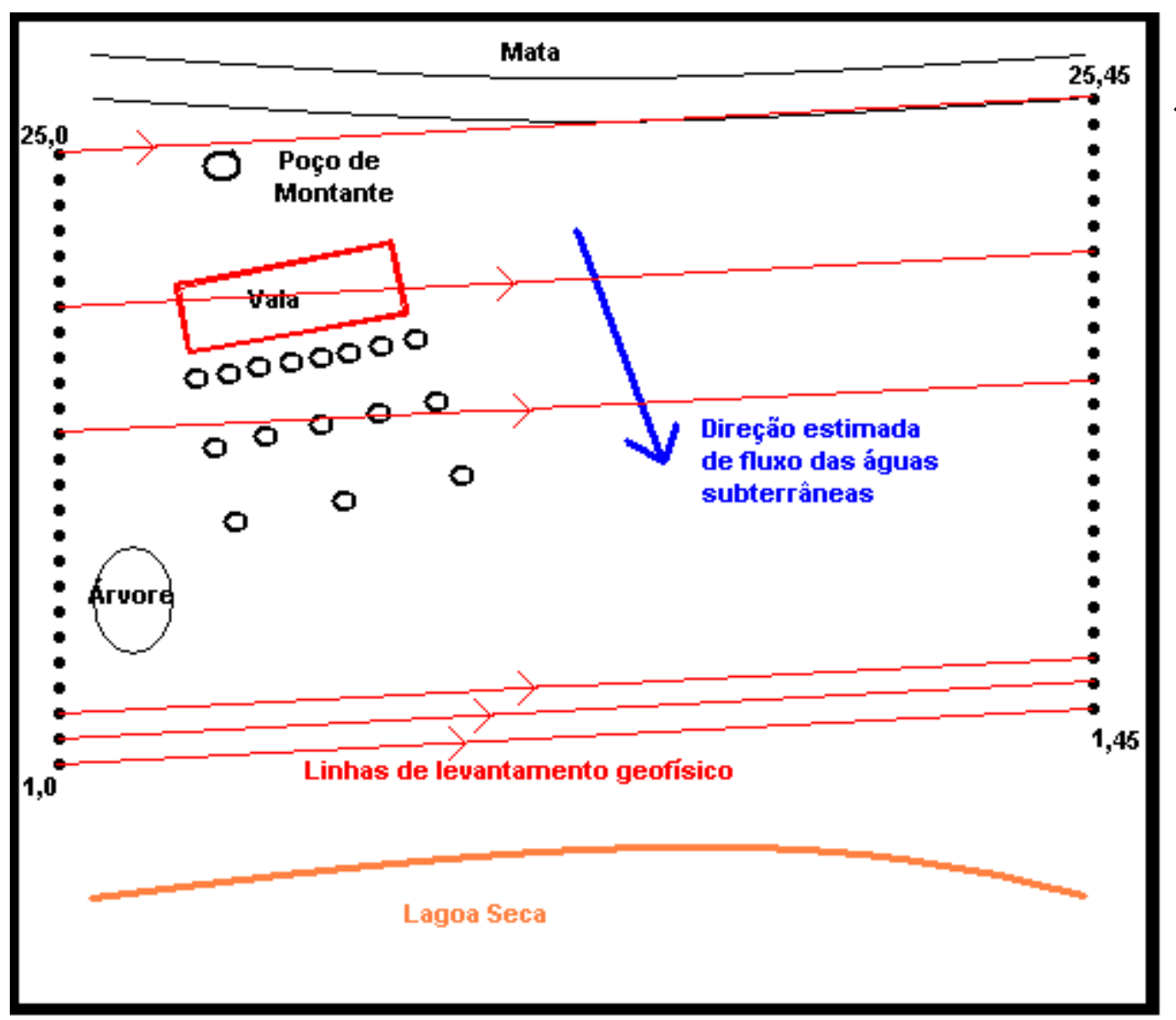

$\mathrm{N}$

Figura 16- Croquis dos levantamentos geofísicos. Situação sem escala. 


\subsubsection{Levantamento Eletromagnético - EM}

Para o levantamento EM foi utilizado equipamento EM-31 fabricado pela empresa canadense Geonics, em função da pequena profundidade de investigação a ser atingida.

Esse equipamento atinge profundidades teóricas de até 6 metros na leitura do campo vertical, e levando-se este dado em conta, foi escolhido pela profundidade do nível do freático na área. Pelos estudos iniciais determinou-se que a cota mínima do freático nos meses de estiagem não ficaria abaixo de cinco metros da superfície.

Os levantamentos pelo método eletromagnético também foram efetuados seguindo-se a orientação das linhas e com medidas a cada 1 metro, sempre no mesmo sentido para não haver inversão entre as posições das antenas de indução e recepção do campo magnético.

O instrumento EM-31 (Foto 18) é constituído de duas bobinas, uma transmissora e outra receptora, conforme exposto anteriormente.

Este instrumento, apesar de antigo, permite fácil manuseio em campo, mas necessita de duas pessoas para operá-lo, tendo em vista seu peso e também a necessidade de fazer a leitura com o equipamento rotacionado sobre seu eixo para medida do campo horizontal.

Durante os levantamentos com este equipamento foram anotadas as presenças de interferências em superfície ou aéreas que possam alterar os resultados, como cercas metálicas e postes de alta tensão. A presença dos poços cacimba construídos para o experimento não alterou os resultados. 


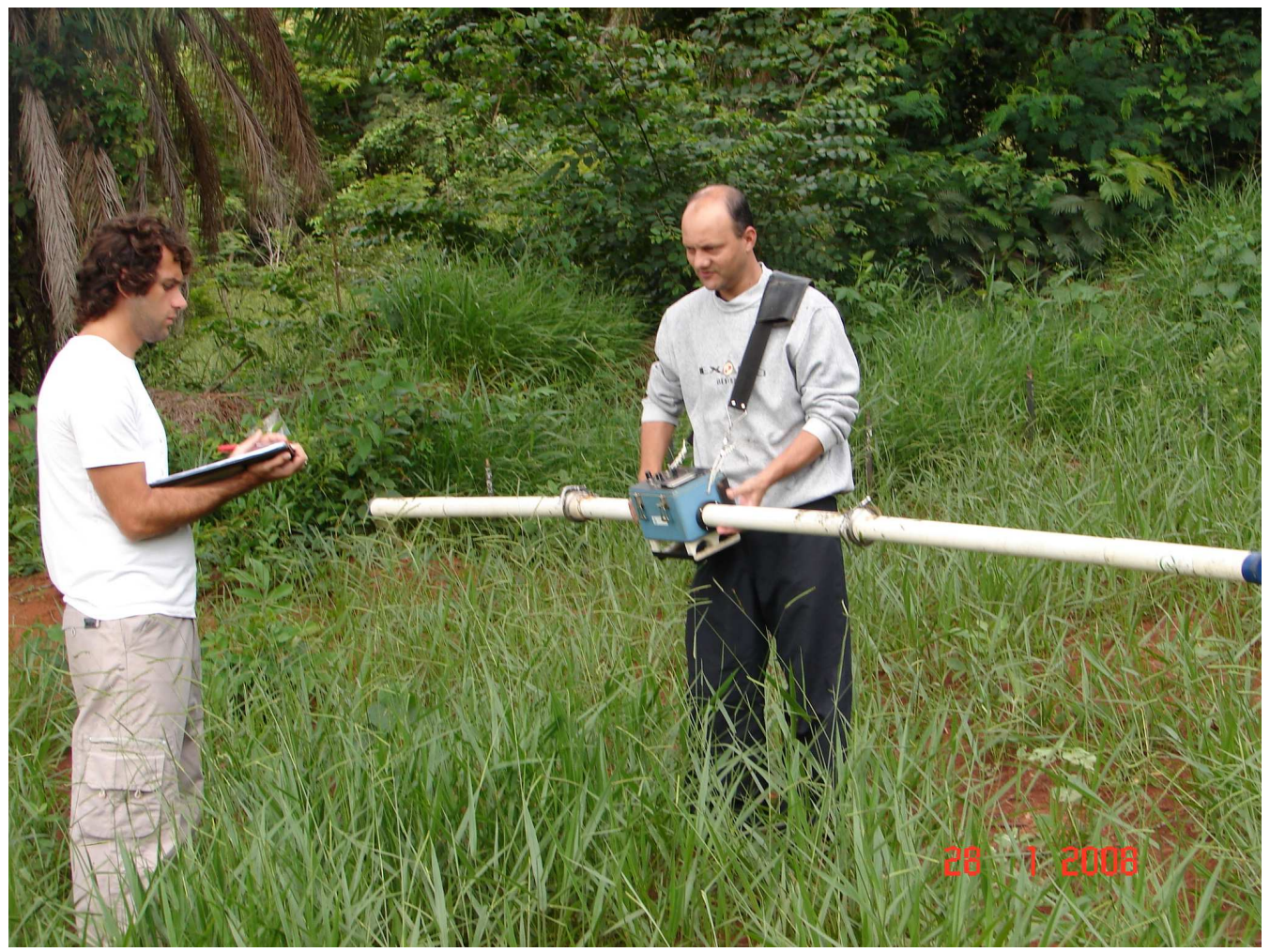

Foto 18 - Levantamento com EM-31 na área da pesquisa.

Os dados foram digitados em planilha Excel® e agrupados os resultados das 25 linhas por etapa para produção de mapa no programa Surfer®. A coordenada do eixo $\mathbf{x}$ correspondente a cada ponto medido nas linhas, ou seja, com valores entre 0 e $48 \mathrm{~m}$. A coordenada do eixo y corresponde ao número da linha medida (entre 1 e 25). Foram produzidos dois mapas para cada etapa, dos campos horizontal e vertical.

\subsubsection{Caminhamento Elétrico - CE}

No levantamento de dados por caminhamento elétrico, foi utilizado o resistivímetro multieletrodo marca IRIS, modelo Syscal Switch Proß, com 48 canais, adquirido com verba da FAPESP. Esse equipamento possui um programa de entrada de dados, denominado Electre $\| \circledast$, que permite montar vários arranjos de campo com os 48 canais, inclusive com a escolha do local do equipamento no início, meio ou fim da linha. A programação com os arranjos escolhidos foi montada em notebook e enviada ao equipamento através de conexão via cabo.

Em todas as etapas de campo o resistivímetro foi locado no meio da linha (Foto 19) para melhor facilidade quando havia necessidade de contornar as árvores da área, por 
segurança, já que nas laterais da área há mato e para melhor visualização dos eletrodos eventualmente desligados ou com mau contato.

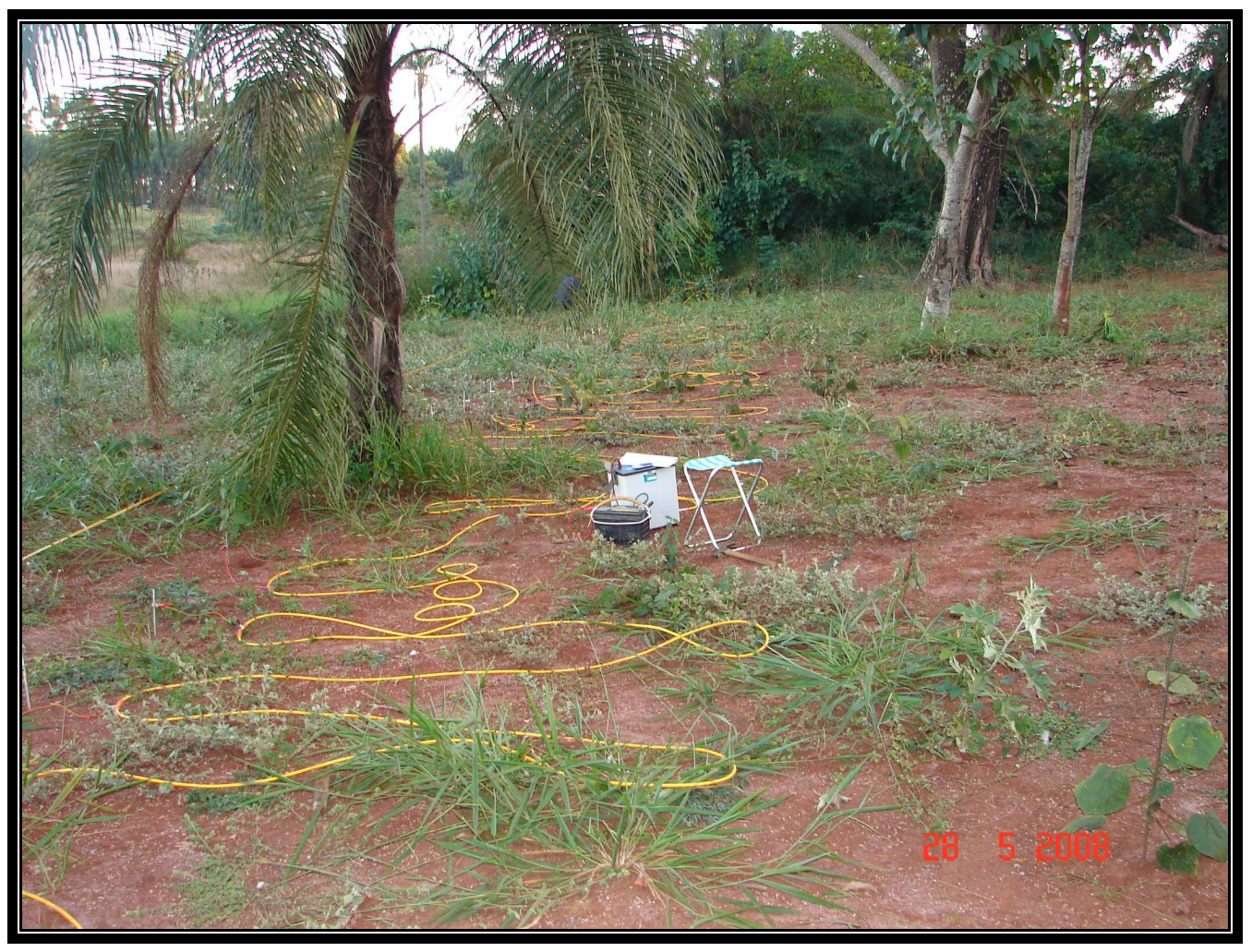

Foto 19 - Levantamento por Caminhamento Elétrico.

Nesta pesquisa foram efetuados perfis com dipolo de 1, 2 e 4 metros, para todas as linhas. Para o dipolo de 2 metros foram feitas medidas iniciando-se a leitura no primeiro eletrodo ímpar e posteriormente nova medida iniciando-se a leitura no primeiro eletrodo par. Essa escolha foi feita considerando que neste trabalho procuraram-se obter os melhores detalhes possíveis e, por isso, adensou-se as leituras de campo. Também foi levado em conta o tamanho da área, a profundidade do nível d'água, do material enterrado e o fluxo subterrâneo estimado.

Para o dipolo de 4 metros foram feitas quatro medidas, também garantindo que neste arranjo fossem feitas medidas em todos os 48 eletrodos da linha. Para isso foram feitas medições iniciando-se o arranjo nos eletrodos 1, 2, 3 e 4, respectivamente. No total, para cada linha em cada fase de campo, foram obtidas 915 leituras para cada linha levantada. 
Após os levantamentos os dados foram transferidos do equipamento para o notebook através de outro software da própria empresa (IRIS), Prosys II, sendo cada linha exportada em formato DAT para uso no software de inversão RES2DINV da Geotomo Software (Loke \& Barker, 1995).

No RES2DINV, a técnica de inversão empregada baseia-se no método dos mínimos quadrados (Gandolfo, 2007) e "suavização vinculada" (smoothness constrained) utilizando algoritmos baseados em um esquema de células. Com isso, segundo este autor, a inversão pode ser efetuada sem a necessidade de que o usuário proponha um modelo geológico inicial e produzindo um modelo de subsuperfície isento das distorções observadas nas pseudo-seções de resistividade aparente, originadas pela geometria do arranjo de eletrodos utilizada (Loke \& Barker, 1995 e 1996).

O software determina de forma rápida e automática um modelo de resistividade $2 \mathrm{D}$ e 3D para dados de tomografia (imageamento geoelétrico) quando sua aquisição se dá nesse formato. Permite ainda a inversão de um grande volume de dados provenientes de diversas configurações (arranjos) de eletrodos (dipolo-dipolo, pólo-dipolo, pólo-pólo, Wenner etc.).

Este software utiliza um modelo inicial que supõe o meio como homogêneo e resistividade constante e igual à media dos logaritmos das resistividades aparentes da pseudo-seção.

Como a área de estudo é pequena e relativamente homogênea, com uma única litologia presente, este software apresenta um valor de partida próximo aos valores medidos, acarretando um pequeno ajuste de erro no modelo final (Gandolfo, 2007). A Figura 17 apresentada por esse autor mostra os dados de campo de uma área com modelo inicial homogêneo e o modelo final com pouca diferença entre a matriz estimada e a verdadeira.

Esse modelo reflete bem as condições encontradas na área de estudo como foi comprovado nas seções obtidas, onde os erros permaneceram sempre baixos, mesmo quando se utilizavam apenas três iterações no software versão teste.

O software RES2DINV possibilita a exportação dos dados em formato $X, Y, Z$. Com os dados $X, Y, Z$ foi montado um arquivo excel com as profundidades de investigação consideradas mais representativas e produzidos mapas da distribuição em planta das 
resistividades destas profundidades no programa SURFER. A coordenada do eixo $x$ utilizada para cada linha é obtida da planilha $X Y Z$, correspondente a cada ponto da linha entre 0 e $48 \mathrm{~m}$ com a resistividade do modelo final. A coordenada do eixo y corresponde ao número da linha medida (entre 1 e 25).

PSEUDO-SEÇÃO DE RESISTIVIDADE APARENTE

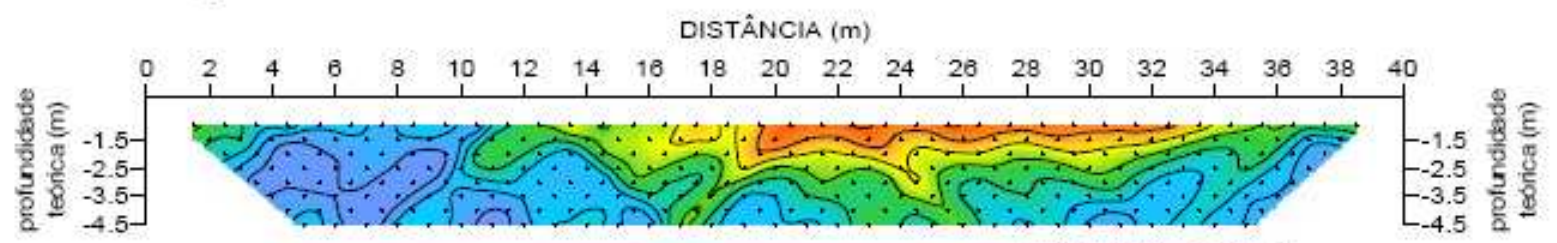

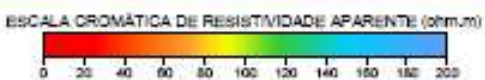

MÁXIMO $=244 \mathrm{ohm} . \mathrm{m}$

MINIMO $=48 \mathrm{ohm} \cdot \mathrm{m}$

MÉDIA = 136 ohm.m

MODELO INICIAL (TERRA HOMOGÊNEA)

contraste $=5 \mathrm{X}$

DISTÂNCIA (m)

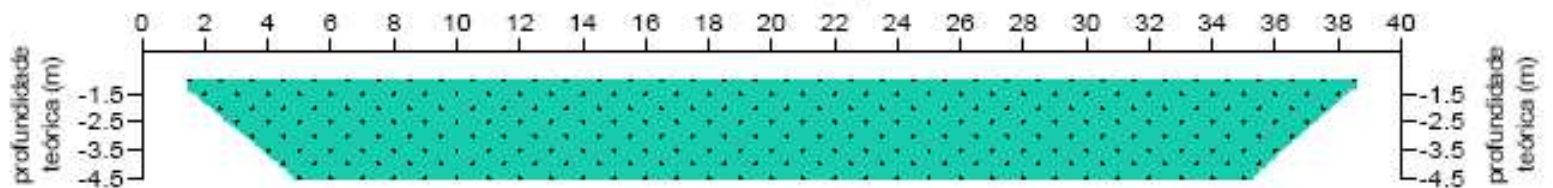

MODELO FINAL

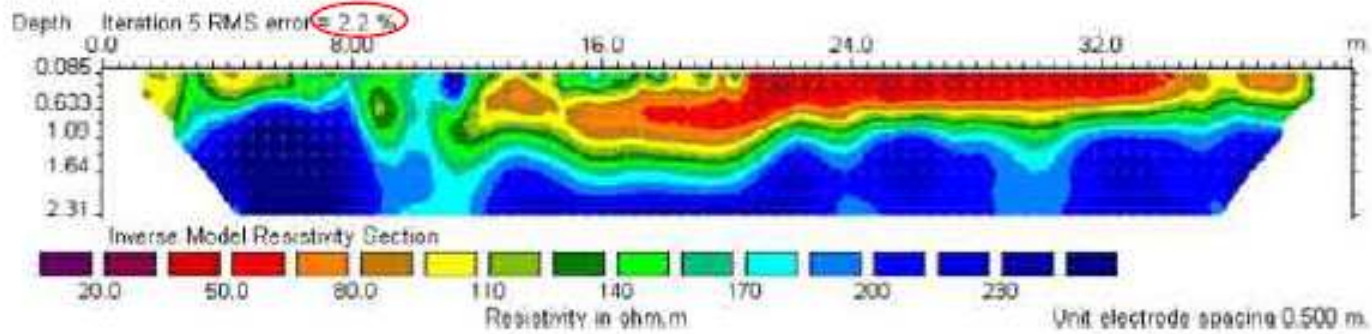

Figura 17 - Dado de campo, modelo inicial de meio homogêneo e modelo final (Gandolfo, 2007). 


\subsubsection{Georradar}

Para os ensaios com o georradar, foi utilizado equipamento modelo RIS fabricado pela IDS (Itália) adquirido através do projeto FAPESP que financiou esta pesquisa. Foi utilizada antena blindada de $100 \mathrm{MHz}$ pela sua definição e boa penetração do sinal na profundidade da pesquisa (Foto 20).

O programa de aquisição do equipamento denominado K2 permite alguns ajustes em relação ao passo, direção do levantamento, eixos iniciais e distância entre linhas no caso de perfis paralelos, ajustando automaticamente a coordenada inicial da linha. Pela facilidade de sua aquisição, as medidas foram efetuadas a cada $2,0 \mathrm{~cm}$ (passo).

A aquisição é feita diretamente no notebook, sendo salva em pastas ou missões (arquivo com extensão .MIS). Durante o levantamento foi possível visualizarem-se algumas feições, tais como vazios e raízes. Algumas destas feições foram checadas com furos de trado e confirmadas, com excelente grau de precisão.

Após a aquisição os dados foram tratados no programa GRED3D também da IDS, sendo possível estabelecer um padrão para tratamento de todas as linhas de uma só vez. Para isso é aberta uma seção qualquer da linha, feitos ajustes tais como a velocidade, filtro passa-banda, freqüência, ganho linear e de suavização. Depois disso o processo é salvo como um macro a ser utilizado no tratamento dos dados.

O programa permite a leitura de todas as linhas ao mesmo tempo em um bloco 3D, havendo a possibilidade de se escolher a visualização de um corte na horizontal em qualquer profundidade a $0,05 \mathrm{~m}$ de distância entre cada seção horizontal, o que foi efetivamente utilizado nesta pesquisa para comparação com os outros resultados, especialmente os de caminhamento elétrico.

O levantamento de campo por georadar foi prejudicado de maneira similar em todas as etapas de campo pela construção dos poços cacimba. O poço construído na porção norte da área sobre a anomalia eletromagnética detectada, impediu o arraste da antena sobre a tampa e sobre o solo retirado na sua escavação (Foto 21). 


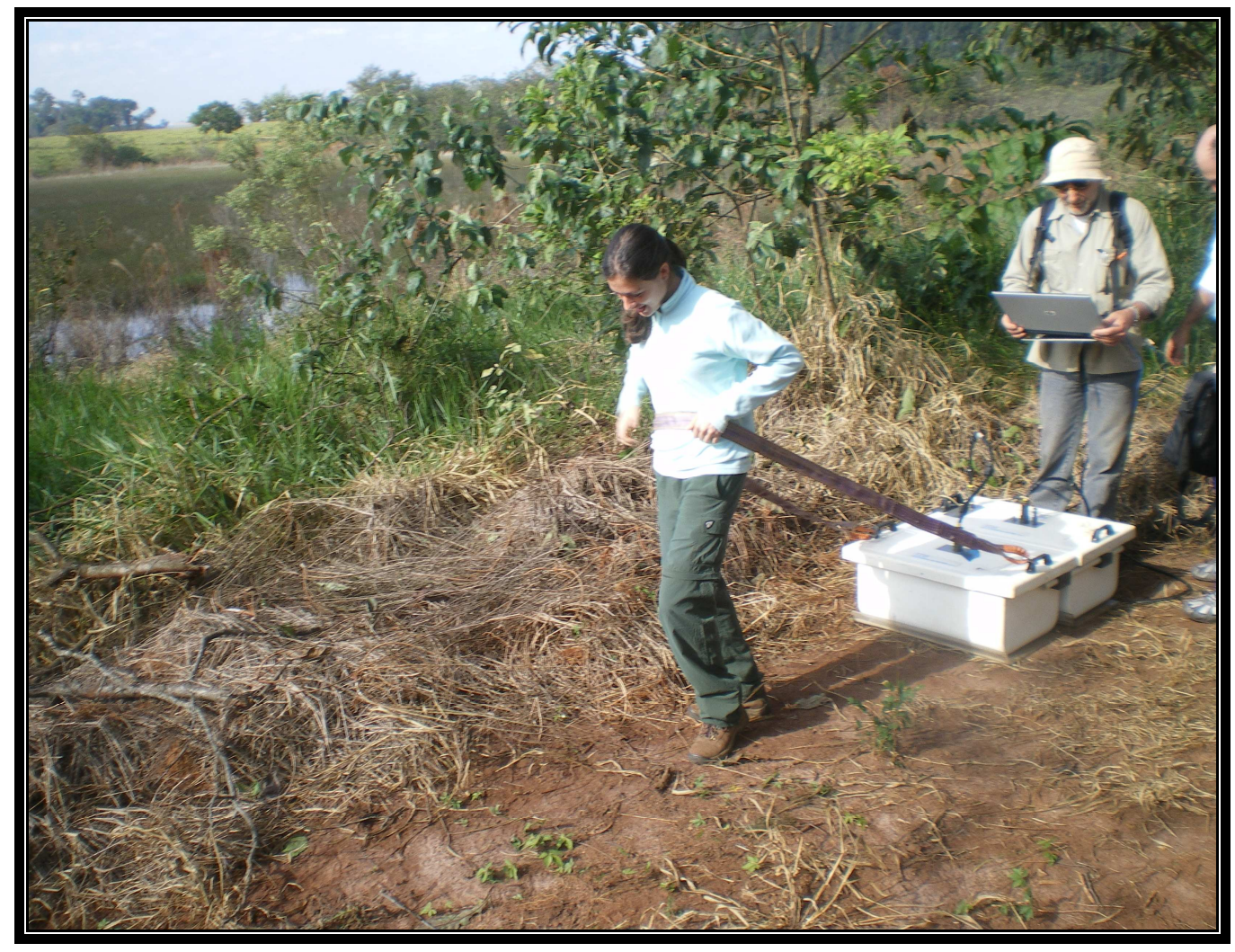

Foto 20 - Levantamento por georradar na área de estudo. Acervo Ana Voltarelli.

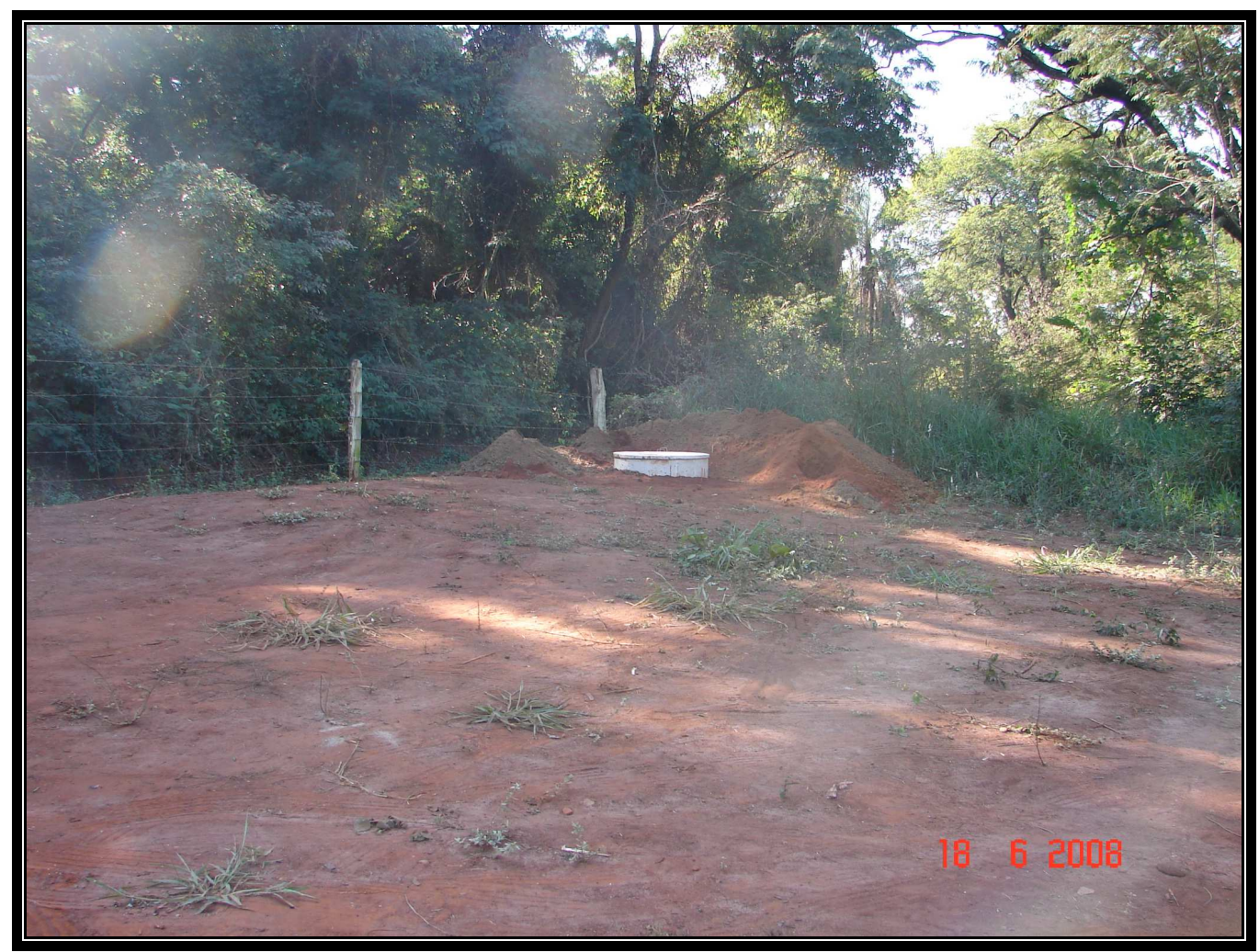

Foto 21 - Detalhe do poço cacimba de montante na porção norte da área, impedindo o levantamento por georradar nesse local. 


\section{Resultados/ Discussão}

Os resultados apresentados se referem às quatro campanhas levantadas nos primeiros meses de trabalho, agosto de 2008 antes da instalação da vala e corpos e as seguintes em outubro de 2008 e fevereiro e abril de 2009.

\subsection{Análises Químicas}

Grande parte da bibliografia sobre o assunto reporta alterações físico-químicas nas águas subterrâneas e solo provenientes da decomposição de corpos enterrados como Migliorini et al (1994), Pacheco (2000) e Matos (2001). Por outro lado, Fielder et al. (2004), Durães et al. (2009) e Castro (2008) em seus estudos mostram resultados diferentes, com poucas alterações nas concentrações dos parâmetros químicos analisados e cujos resultados indicam haver outros condicionantes no processo de decomposição que retardam ou retêm a liberação dos íons pelos corpos em decomposição.

Neste estudo foi notada uma alteração muito sutil de alguns íons analisados, para os quais se esperava uma anomalia substancial provocada pela formação de necrochorume na região dos poços de monitoramento instalados. Estes resultados das campanhas de amostragem, na forma de tabela, encontram-se no Anexo I.

A grande maioria dos resultados mostra alterações que aparentam encaixar-se dentro de variações sazonais e não efetivamente provocadas pelo experimento. As hipóteses iniciais que se levantaram para tal fato foram:

- colocação dos corpos em região saturada do solo ou com grande infiltração e movimentação de água no período chuvoso que se seguiu ao enterro, provocando a formação de adipocera e retenção dos elementos;

- retenção dos íons pelo solo, pois o teor de argilas na área da vala associado à presença de matéria orgânica de origem vegetal foi suficiente para provocar esta situação;

- deposição de matéria orgânica insuficiente no experimento, provocando pouca alteração destes elementos pelo volume pequeno de necrochorume formado;

- instalação dos poços de monitoramento em profundidade inadequada, apesar de possuírem seção filtrante de $2 \mathrm{~m}$ de comprimento; 
Em relação a esta possibilidade de instalação dos poços em profundidades inadequadas, podem ter ocorrido duas situações:

- o necrochorume formado, por ser mais denso que a água $\left(1,24 \mathrm{~g} / \mathrm{cm}^{3}\right)$ penetrou na zona saturada até porções mais profundas que os filtros instalados, tendo então migrado lateralmente nesta região ou,

- mesmo sendo mais denso que a água, o necrochorume por ser solúvel se dissipou nas camadas mais altas da zona saturada e, dado o grande aporte de água e velocidade de fluxo, migrou rapidamente.

De qualquer maneira a concentração final foi insuficiente para alterações marcantes nas águas coletadas dos poços de monitoramento. As alterações efetivamente notadas após o enterro dos corpos são analisadas a seguir.

Para o parâmetro fósforo foi medido aumento até dez vezes as concentrações da campanha inicial, especialmente nos poços PM5 a PM10, junto à vala. A partir desta campanha os valores diminuem no período chuvoso, voltando a um pequeno aumento no inverno de 2009. Esta variação, entretanto, é atribuída a variações normais sazonais já que também ocorre no poço de montante PM1.

Em relação a fosfatos, ocorre um decréscimo entre a primeira e segunda campanhas realizadas. Após o período de chuvas, em fevereiro de 2009 as concentrações atingem valores próximos aos iniciais, voltando a repetir este ciclo nos meses subseqüentes de maneira similar para todos os poços, inclusive o de montante.

A concentração de ferro sofreu aumento pouco significativo, à exceção talvez das amostras coletadas no PM5, condizente com a direção de fluxo subterrâneo. A concentração da amostra da campanha efetuada um mês após a colocação dos corpos não ultrapassou duas vezes o valor da primeira campanha, antes da intervenção na área.

A análise de DOC - Carbono Orgânico Dissolvido - especialmente na segunda campanha (Figuras 18 a 21) mostra alterações mais expressivas, com variação no poço 7 de $0,40 \mathrm{mg} / \mathrm{L}$ em agosto de 2008 para $1,20 \mathrm{mg} / \mathrm{L}$ em outubro de 2008 , ou seja, um aumento de $200 \%$. A concentração de DOC se mantém ainda mais elevada em fevereiro de 2009 (durante a estação das chuvas), apesar da maior diluição provocada pela água meteórica. Em adição, é interessante notar que as concentrações de carbono dissolvido se mantêm acima dos níveis iniciais mesmo após um ano da deposição dos corpos, o que 
concorda com a bibliografia que estipula um prazo mínimo de um ano para a decomposição dos tecidos.

Os resultados para o parâmetro cloreto mostram algumas alterações na terceira campanha efetuada em fevereiro de 2009. Os resultados anômalos se concentram na área entre os poços PM7 e PM12, porém voltando a valores similares aos outros poços já na campanha seguinte, em abril de 2009 (Figuras 22 a 25).

$\mathrm{Na}$ análise de nitrato, os aumentos de concentração são notados na análise de fevereiro de 2009 voltando aos níveis normais nas campanhas subseqüentes. Mesmo nessa análise as alterações não foram maiores que $25 \%$ do valor original.

Os resultados de análise de nitrito mostram apenas variações similares para quase todos os poços nas campanhas efetuadas. Há um aumento discrepante no poço PM8 na campanha de outubro de 2008, mas que não tem continuidade nas campanhas subseqüentes.

Todos os outros parâmetros analisados mostram ausência de anomalias na concentração, incluindo sódio, pH e potássio, para os quais se esperava aumento nas concentrações pelo suposto aporte de íons originados da decomposição.

O fato talvez mais relevante dos resultados é a total ausência de variação nos valores da condutividade elétrica das amostras de água coletadas. Além das medidas em campo foram também checadas as amostras em laboratório, não havendo variação significativa entre as duas medições (menos de 1\%).

Os valores encontrados em todas as etapas de campo (Figuras 26 a 29) mostram valores de condutividade da ordem de $20 \mu \mathrm{S} / \mathrm{cm}$, ou seja, as águas se mostram muito pouco condutivas, valor similar à de água de chuva. Esse resultado indica a grande mobilidade das águas em subsuperfície e sua estreita relação com a infiltração das águas pluviais, sem aporte sensível de íons provenientes do solo.

Como já mencionado anteriormente, deve ser ressaltada a possibilidade de que a contaminação pelo necrochorume tenha migrado para uma profundidade maior devido a sua densidade mais elevada, abaixo da profundidade em que foram coletadas as amostras e medidas as condutividades das amostras de água. 

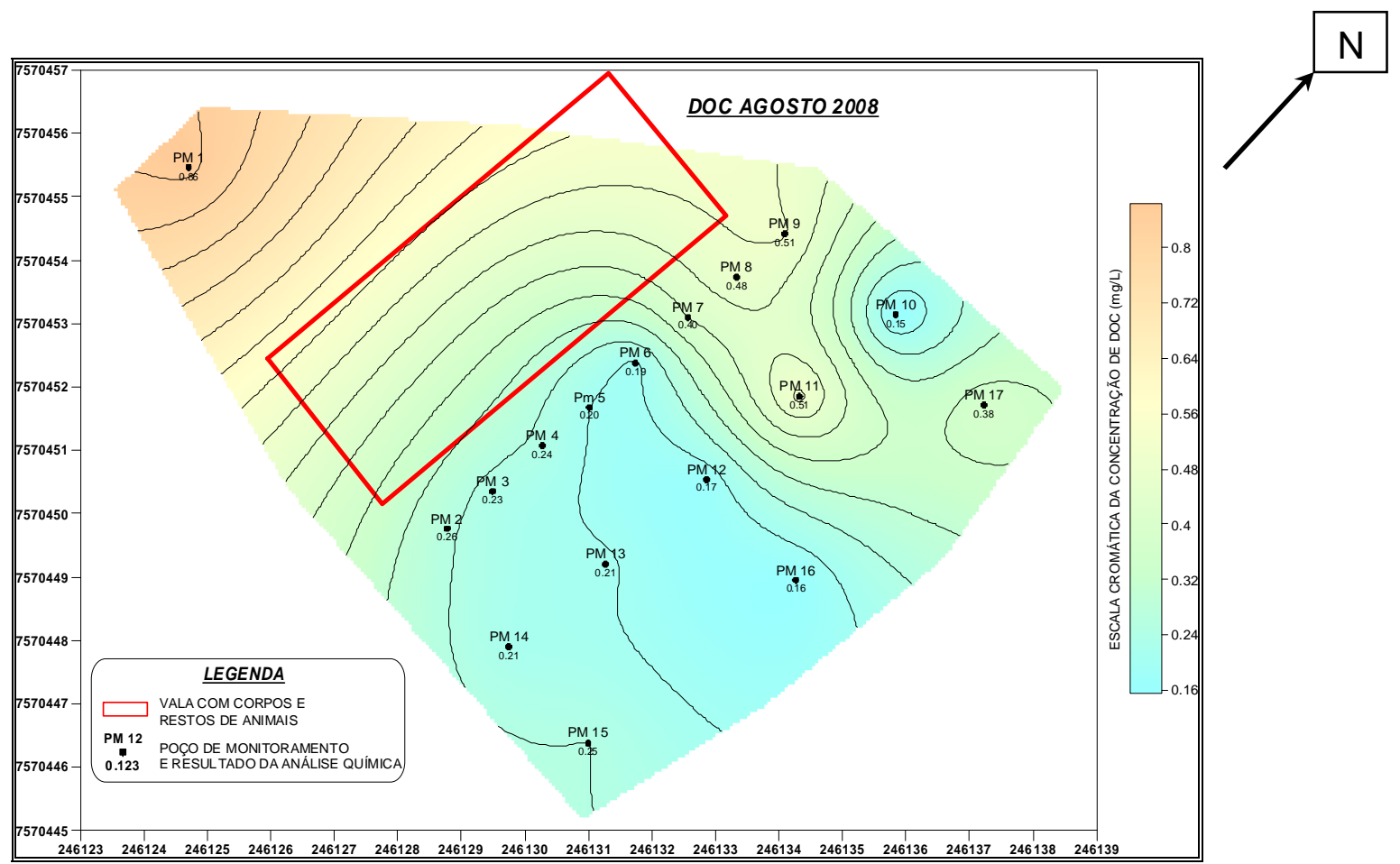

Figura 18 - Curvas de isovalores para DOC em agosto de 2008.

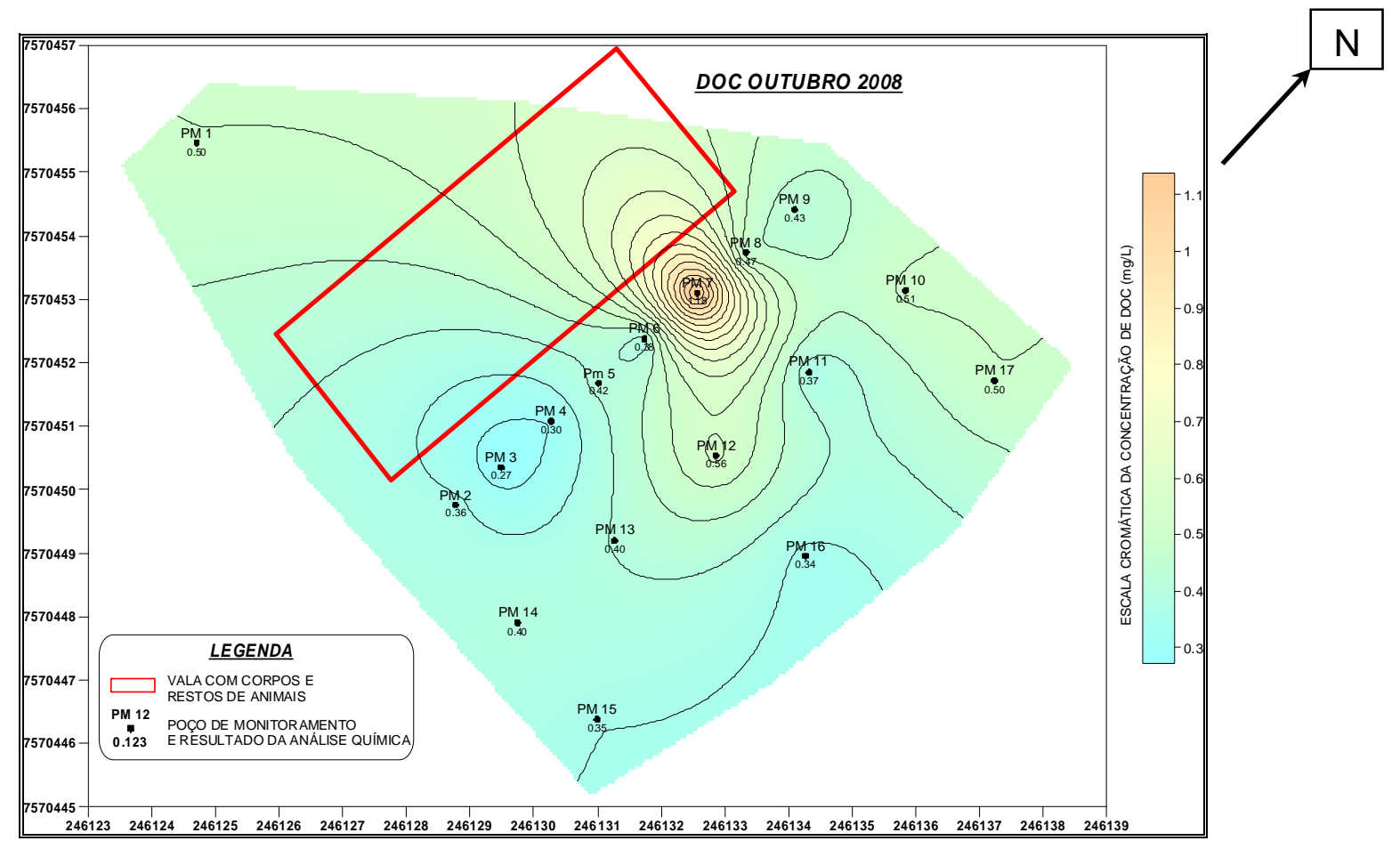

Figura 19 - Curvas de isovalores para DOC em outubro de 2008. 


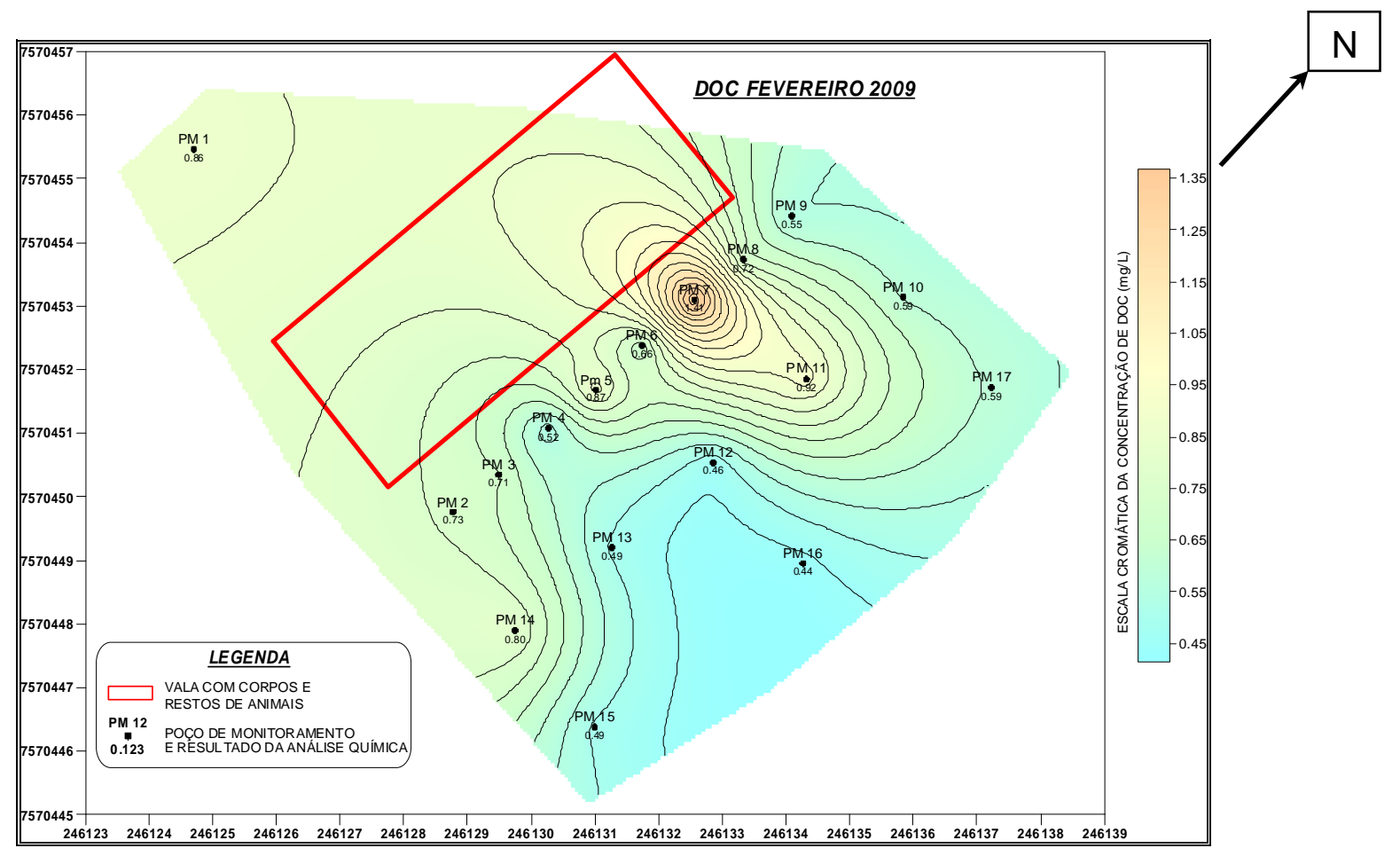

Figura 20 - Curvas de isovalores para DOC em fevereiro de 2009.

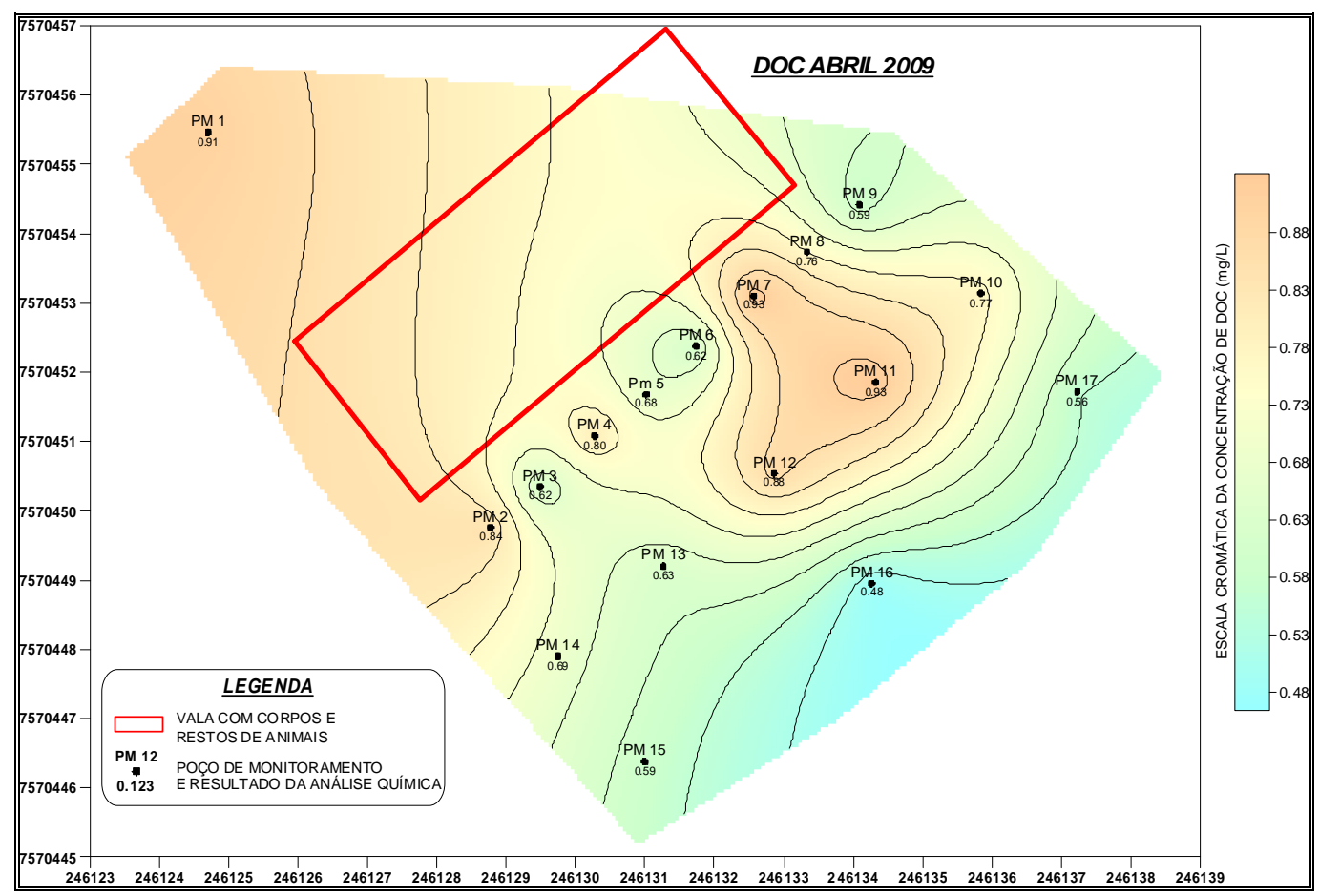

Figura 21 - Curvas de isovalores para DOC em abril de 2009. 


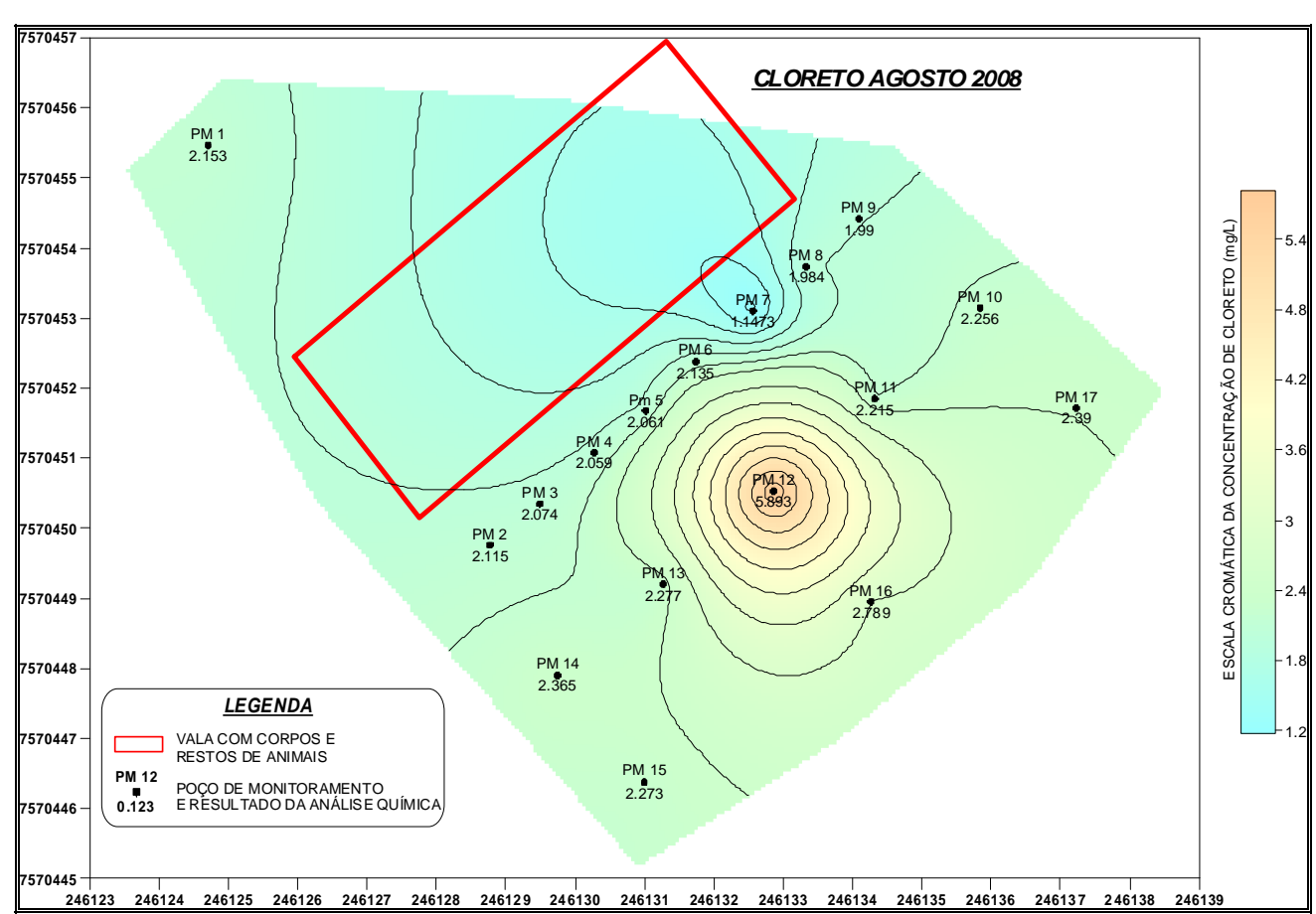

Figura 22 - Curvas de isovalores para cloreto em agosto de 2008.

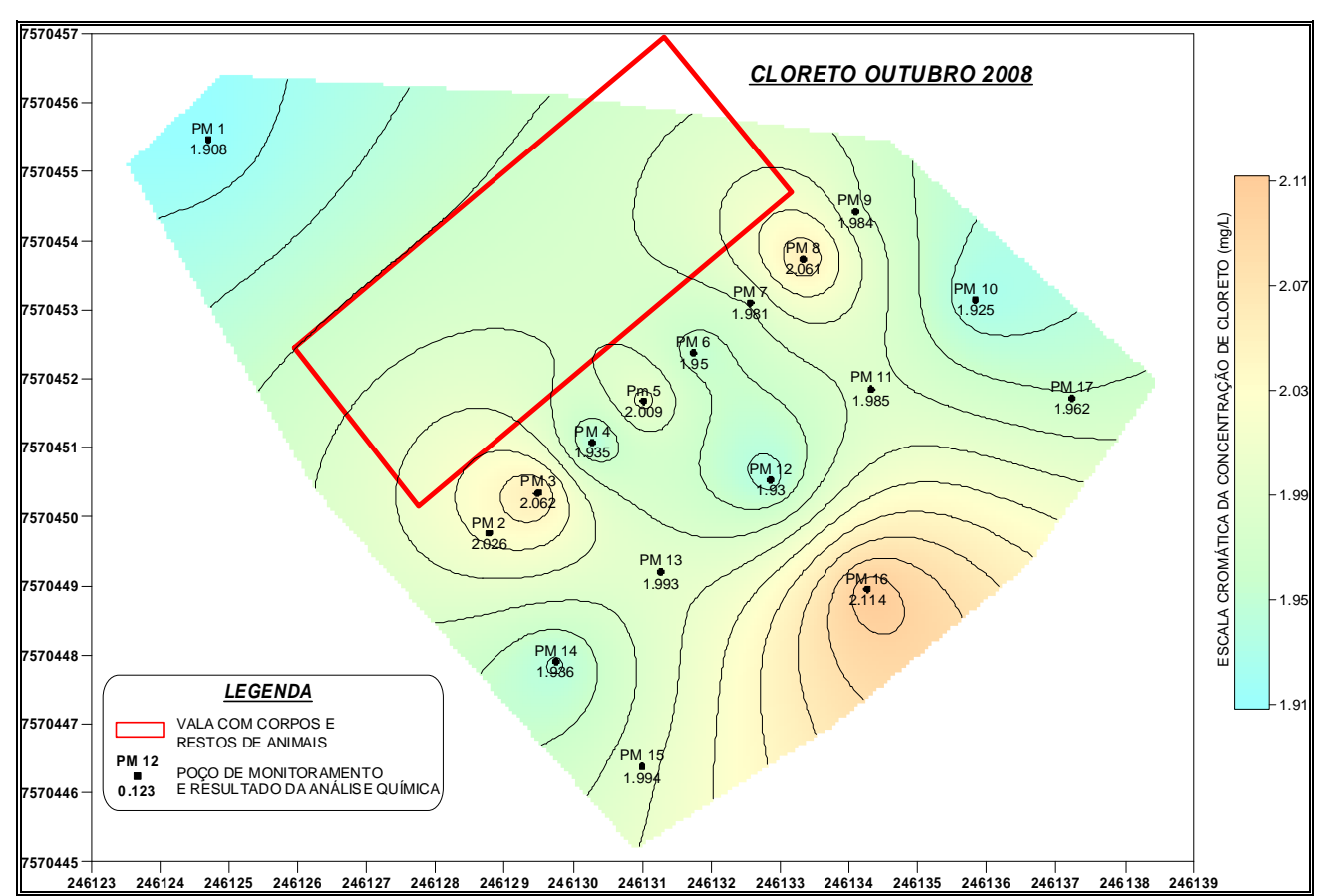

Figura 23 - Curvas de isovalores para cloreto em outubro de 2008. 


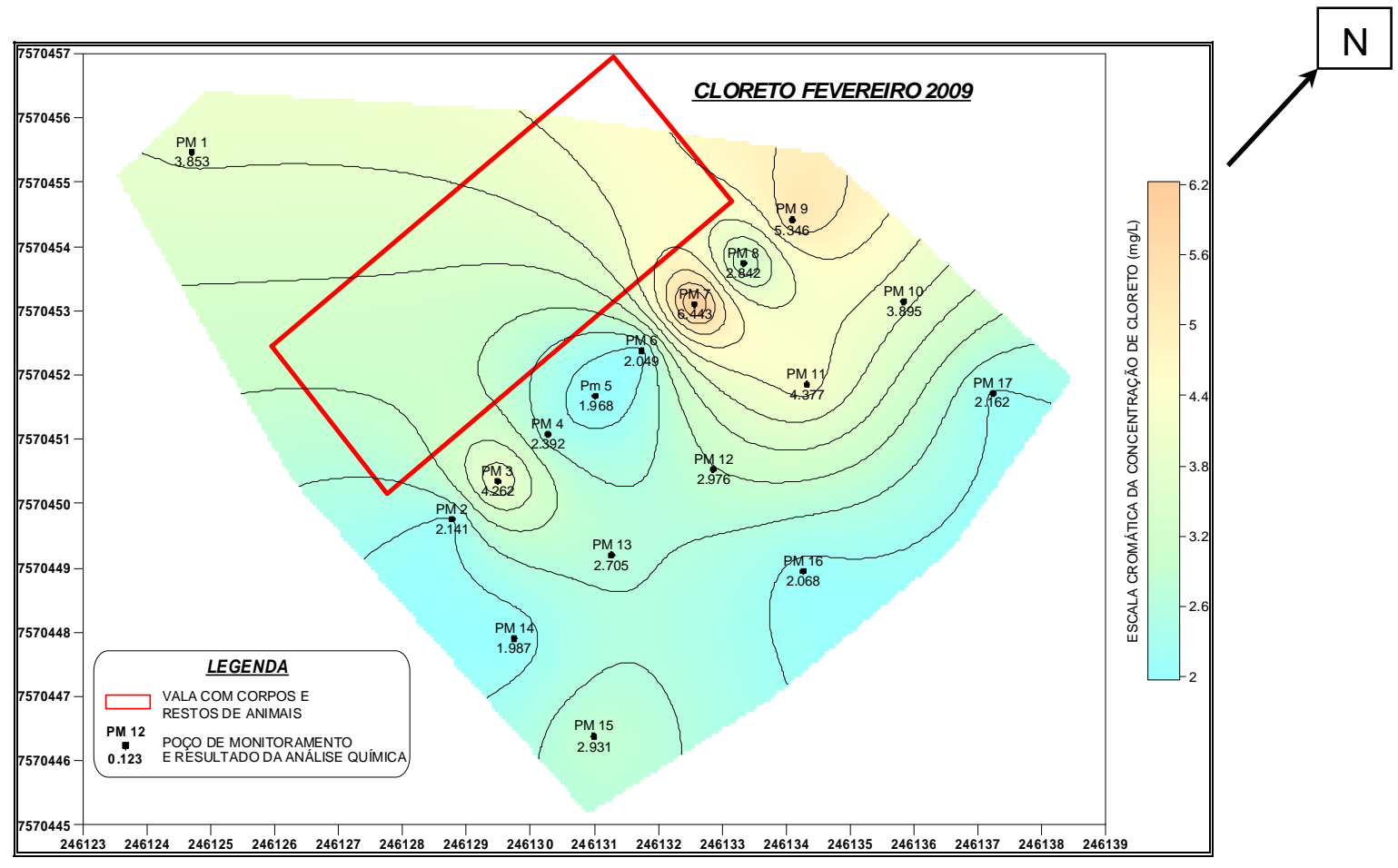

Figura 24 - Curvas de isovalores para cloreto em fevereiro de 2009

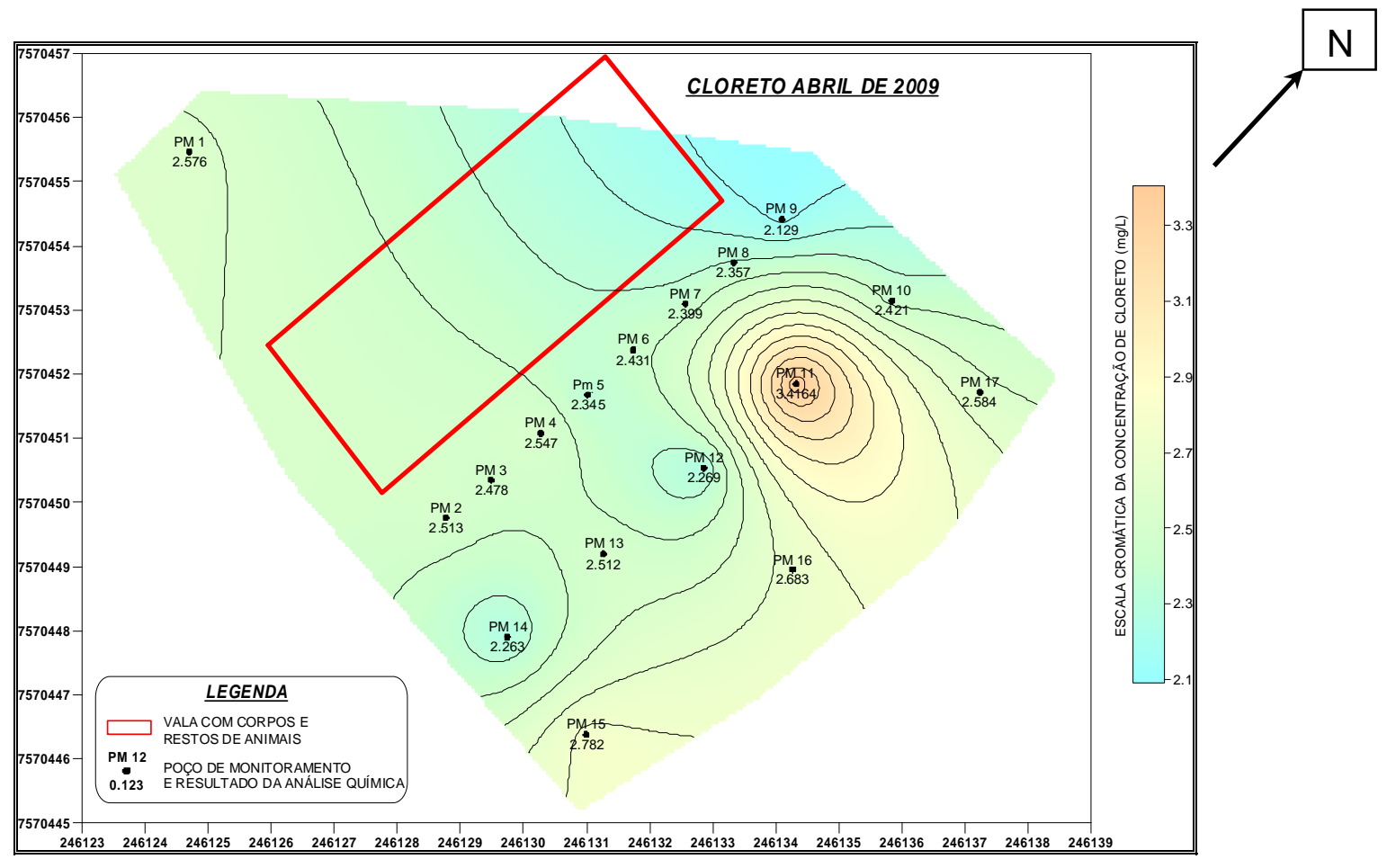

Figura 25 - Curvas de isovalores para cloreto em abril de 2009. 


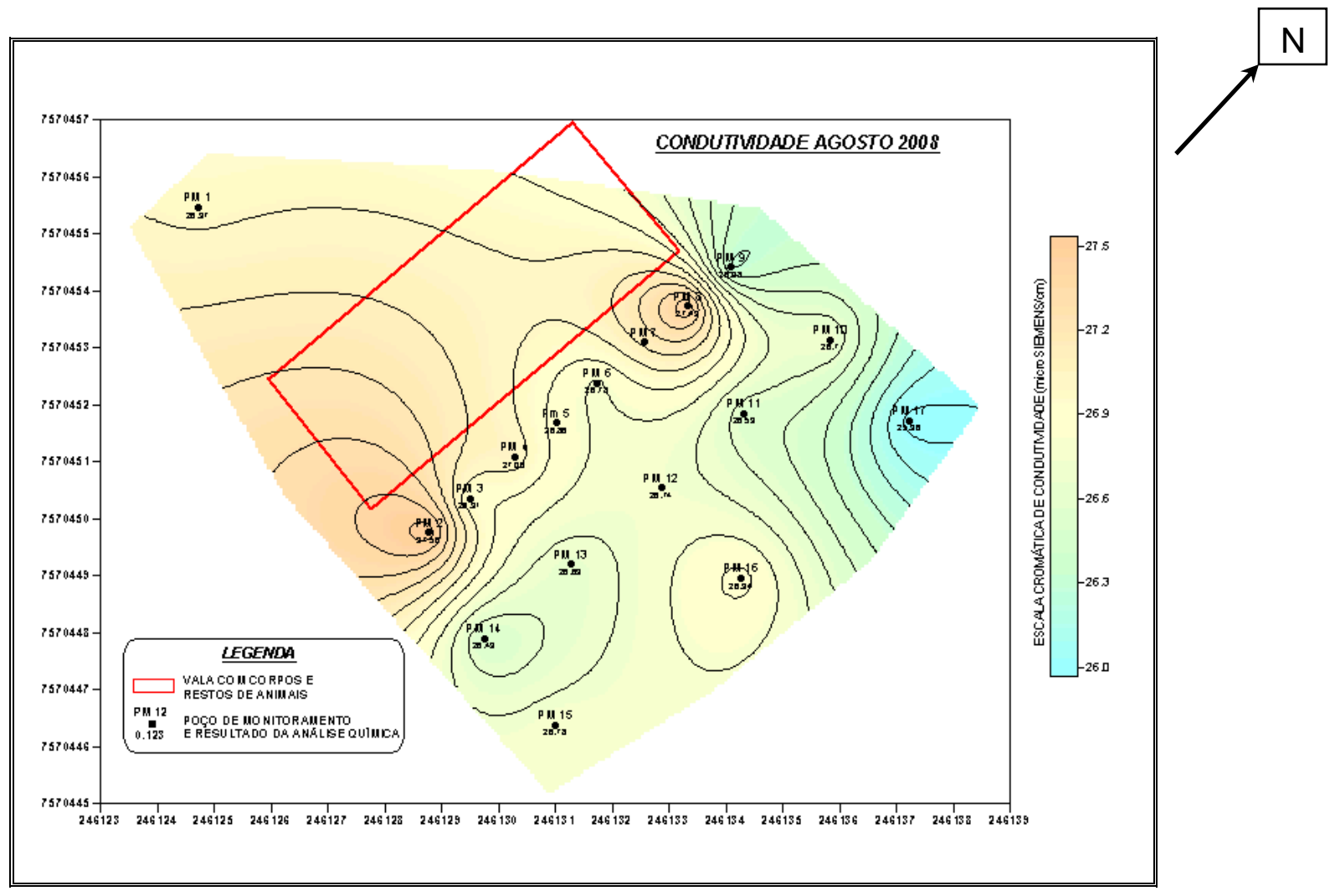

Figura 26 - Curvas de isovalores para condutividade elétrica na água em agosto de 2008.
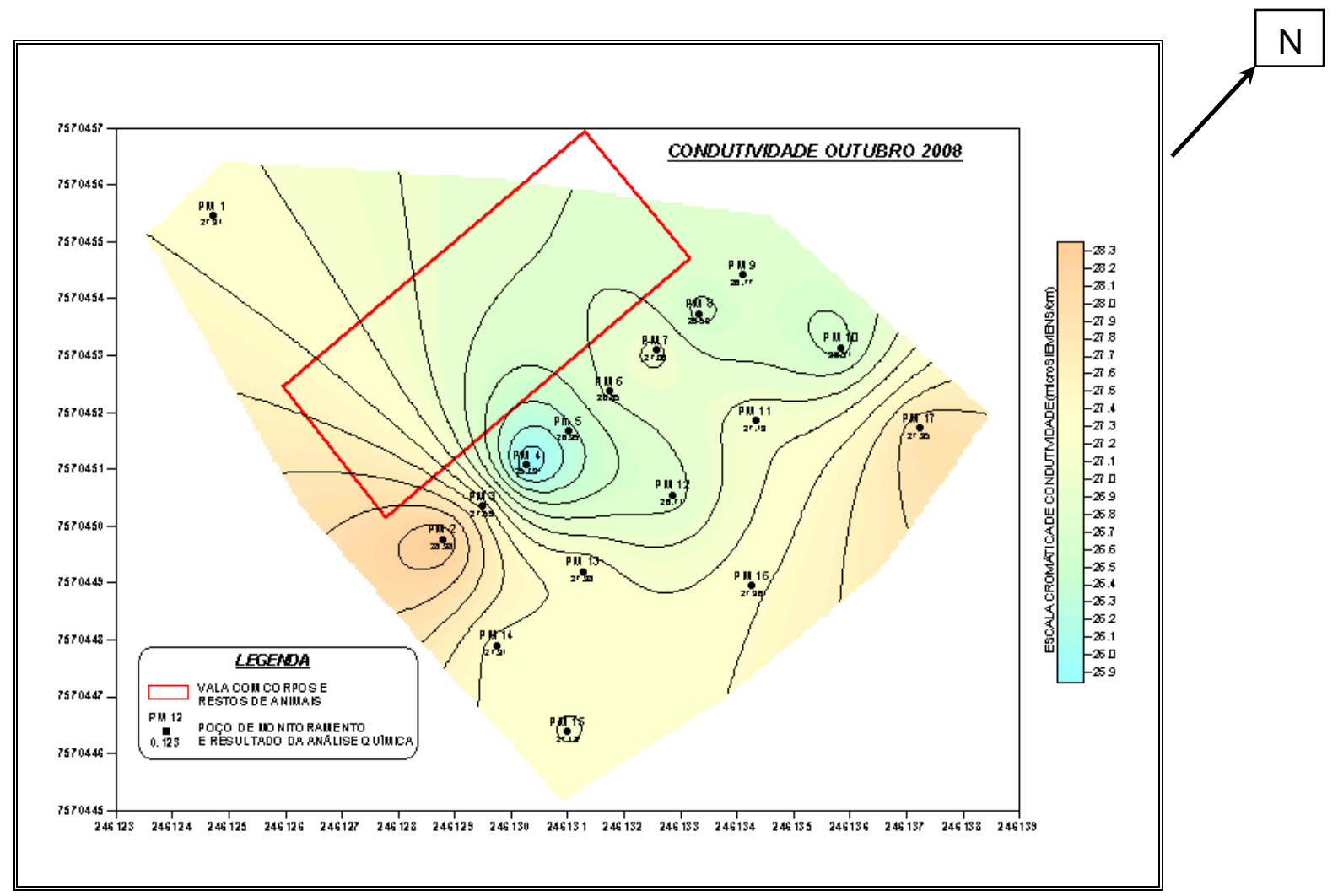

Figura 27 - Curvas de isovalores para condutividade elétrica na água em outubro de 2008. 


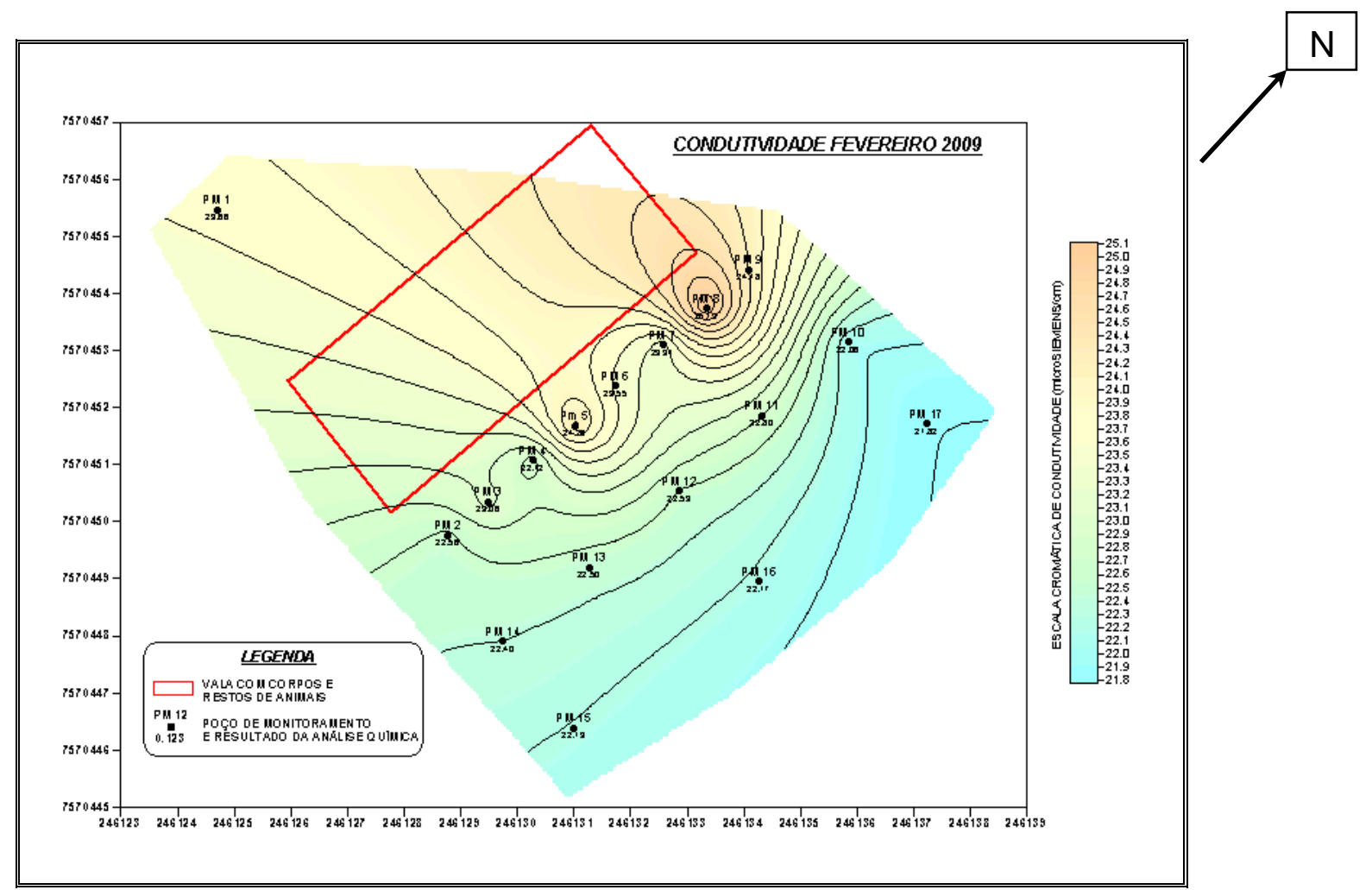

Figura 28 - Curvas de isovalores para condutividade elétrica na água em fevereiro de 2009.

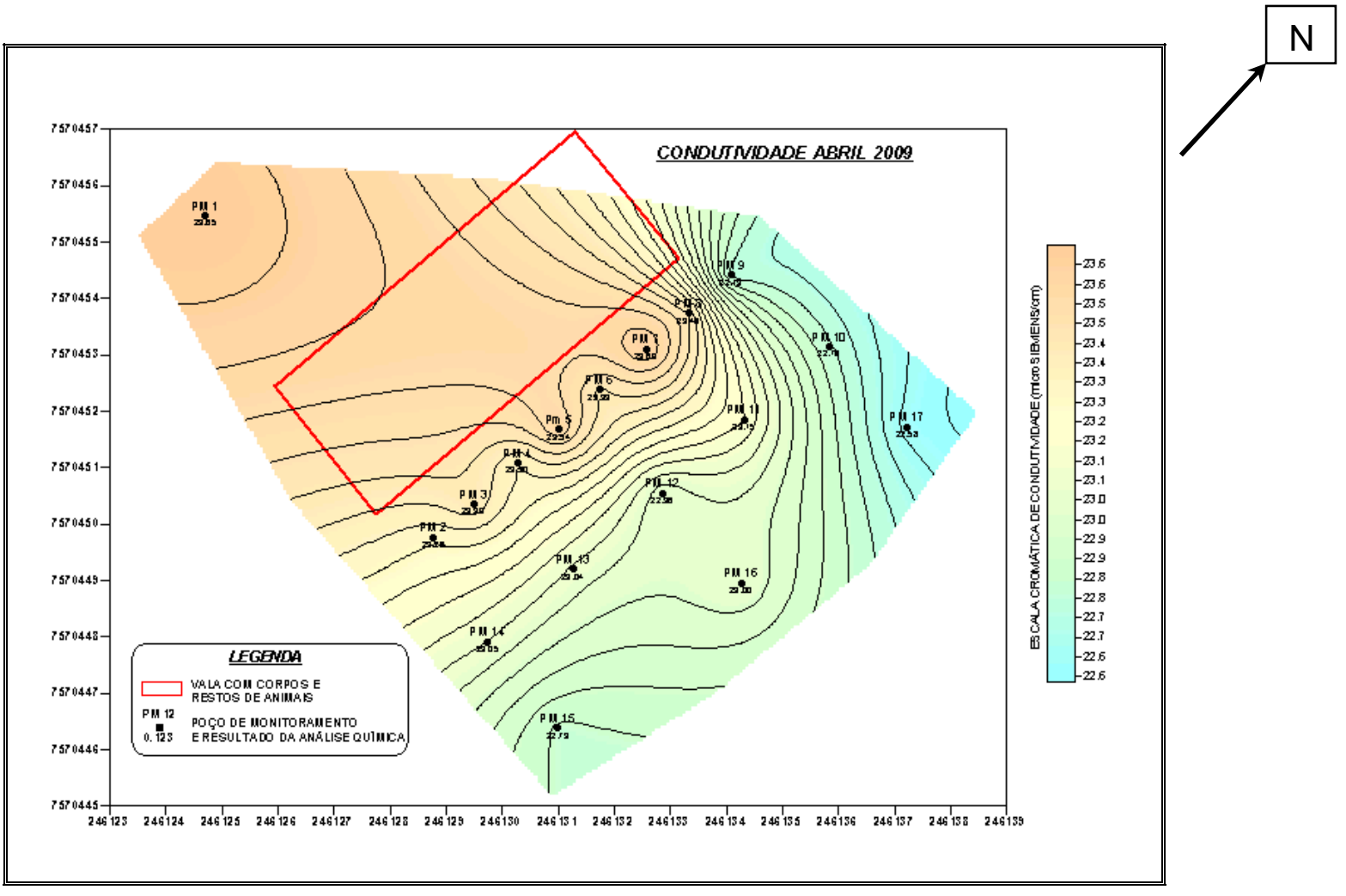

Figura 29 - Curvas de isovalores para condutividade elétrica na água em abril de 2009. 


\subsection{Ensaios Geofísicos}

Os ensaios geofísicos mostram resultados bastante díspares, que têm relação com a resolução dos métodos ou equipamentos, influência do substrato local e variação do nível do freático e com a concentração e direção de fluxo dos contaminantes gerados pelo experimento.

\subsubsection{EM}

O levantamento pelo método eletromagnético mostra em todas as fases da pesquisa o mesmo resultado para a área, especialmente as anomalias naturalmente existentes nos seus limites.

No levantamento inicial, sem histórico de ocupação, os valores de base (background) encontrados mostraram-se baixos, da ordem de 0,5 a $3 \mathrm{mS} / \mathrm{m}$, tanto no campo vertical como horizontal, eventualmente pouco mais elevados nos períodos de elevação do nível do freático.

Desde o primeiro levantamento foi detectada uma anomalia localizada no extremo norte da área, junto à cerca de divisa com a estrada de acesso, presente tanto no campo horizontal como vertical, sendo que em ambos os campos os valores locais atingem o máximo de $700 \mathrm{mS} / \mathrm{m}$.

Foi feita uma linha de levantamento paralela à cerca para se avaliar a influência do metal do arame farpado nos resultados. A anomalia, entretanto, fica restrita aos pontos finais de medidas das linhas 24 e 25 , descartando-se esta origem para uma anomalia tão elevada.

A locação do poço cacimba de montante, utilizado para descrição do solo, foi propositadamente feita sobre esta anomalia. Não foi detectada a presença no solo ou nas lâminas efetuadas qualquer material que possa provocar esta alteração.

A anomalia tem sua origem, portanto, relacionada a eventos antrópicos ou condições geológicas localizadas fora da área do experimento. De qualquer maneira, para a pesquisa em si sua presença não é importante, pois os corpos e o experimento foram implantados a oeste deste local, afastados mais de vinte metros e fora do sentido de fluxo das águas subterrâneas. 
A anomalia da porção mais baixa, a sul e sudeste, está relacionada ao nível do aqüífero semi-aflorante junto à Lagoa Seca, como foi comprovado pelas SEVs efetuadas e pela clara elevação do freático por confirmação visual no poço cacimba de jusante e na própria Lagoa Seca.

Os diferentes resultados obtidos em campo, relativos à variação do nível do freático na área ficam evidentes nas Figuras 30 e 31, onde são apresentados os mapas do campo vertical antes da colocação dos corpos e um mês após sua deposição na vala.

Nota-se, no mapa de agosto de 2008, a influência do nível freático nas porções sul e leste da área, junto à Lagoa Seca. No levantamento seguinte, em outubro de $2008 \mathrm{com}$ o rebaixamento do nível freático, os valores de condutividade elétrica decrescem sensivelmente.

Os resultados de todas as campanhas (Anexo II), tanto para o campo horizontal como vertical se limitam a mostrar a variação relativa a maior ou menor presença de água subterrânea nos pacotes estudados.

Ao contrário do esperado para o local, no campo horizontal, mais raso, ocorrem valores de background mais elevados que para o campo vertical, onde deve haver maior influência do freático na condutividade do pacote analisado. Aparentemente, a porção mais rasa do solo tem maior influência nos resultados, possivelmente pela presença de água retida na grande quantidade de raízes encontradas em níveis mais superficiais.

Os resultados, portanto, são insuficientes para apontar qualquer variação no substrato originada pelo aporte de contaminantes provenientes da decomposição dos corpos enterrados.

Mesmo utilizando-se escala com intervalos da ordem de $0,5 \mathrm{mS} / \mathrm{m}$ não é possível notar qualquer variação na região onde se situa a vala ou a jusante desta, na direção do fluxo dos contaminantes e água subterrânea. 


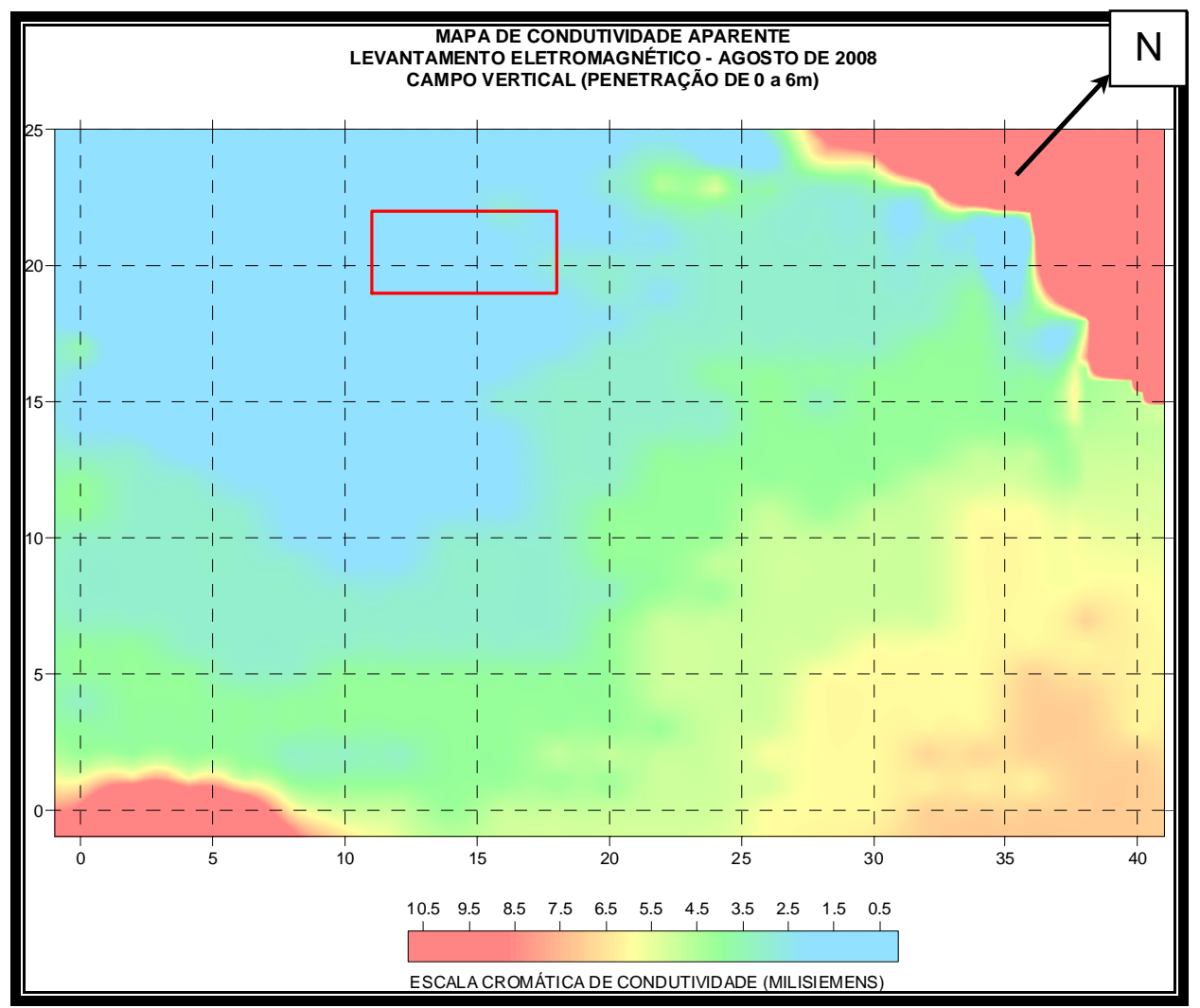

Figura 30 - Mapa de condutividade no campo vertical em agosto de 2008.

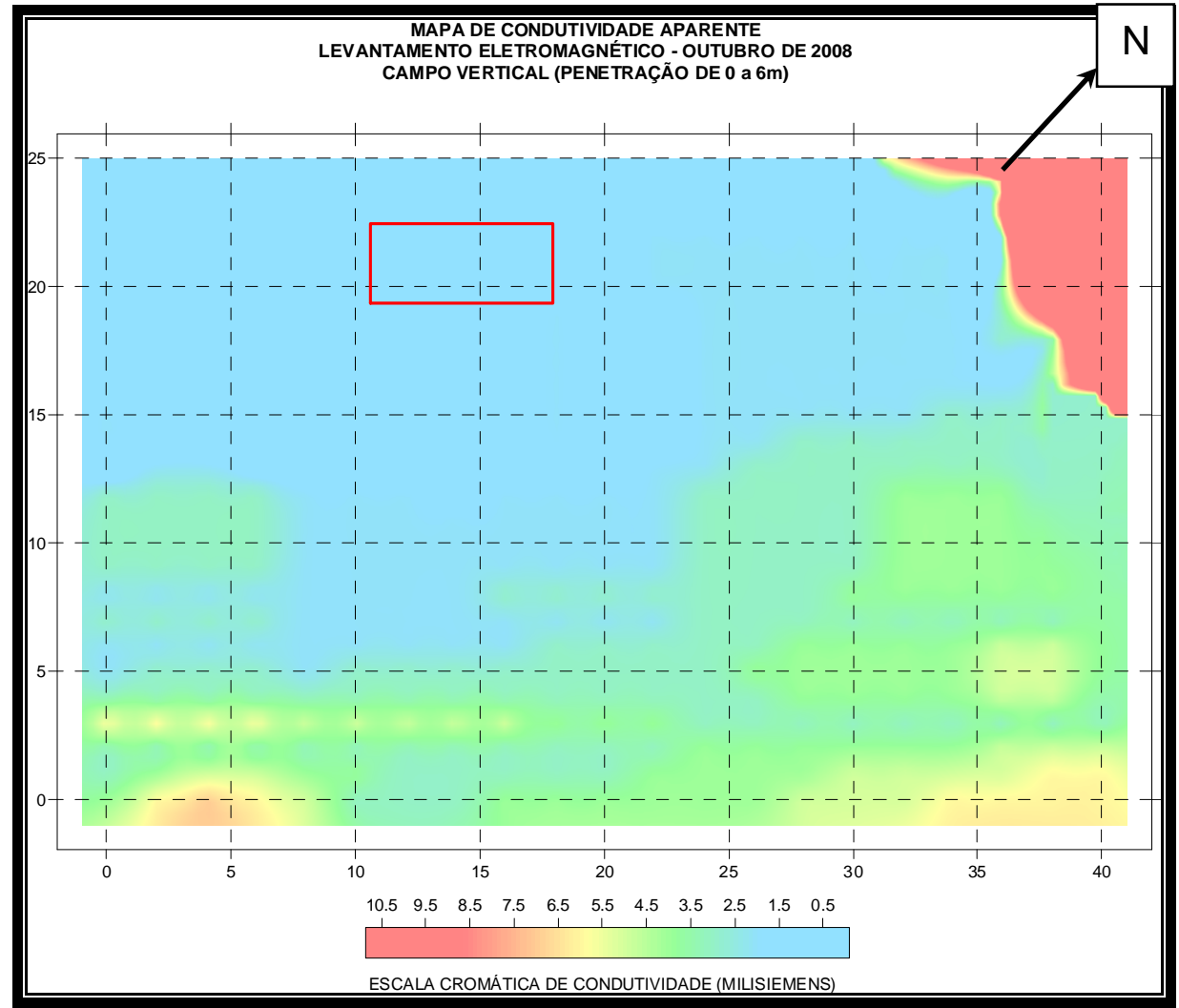

Figura 31 - Mapa de condutividade no campo vertical em outubro de 2008 
Comparando-se estes resultados com os obtidos por Senos Matias et. al (2004) onde foram claramente definidas as plumas de contaminação nos cemitérios de Gafanha do Carmo e Gafanha da Encarnação, duas hipóteses podem ser levantadas para a não detecção das alterações por este método:

- A quantidade de elementos químicos liberados pelo experimento foi insuficiente para a detecção pelo EM-31, mostrando que o equipamento, apesar de muito eficiente no experimento de Portugal, não possui resolução para detecção de anomalias de baixo valor.

- A profundidade em que se deu a alteração foi superior à investigada pelo equipamento mesmo quando se investiga o campo vertical, teoricamente de 0 a $6 \mathrm{~m}$ de profundidade, lembrando-se que as áreas investigadas em Portugal mostram resultados claros mesmo no campo horizontal, apontando para alterações já no pacote raso, entre 0 e $3 \mathrm{~m}$. Isso corrobora a hipótese de migração do necrochorume a profundidades maiores devido à sua densidade.

\subsubsection{Georradar}

Todos os perfis foram realizados com antena de $100 \mathrm{MHz}$, de menor freqüência disponível no acervo do Instituto de Geociências para que, de acordo com as condições presentes, fosse possível a investigação até a profundidade de 6,0 m. Os resultados são apresentados no Anexo III onde são mostrados os resultados em perfis paralelos à superfície topografica nas profundidades $3,20 \mathrm{~m}, 3,95 \mathrm{~m}$ e $5,75 \mathrm{~m}$ relativos às quatro campanhas analisadas.

Os resultados obtidos com as seções de georradar da primeira campanha na área mostram com maior definição, ao contrário do método eletromagnético, e situação heterogênea em subsuperfície, apresentando hipérboles que são associadas a vazios ou raízes e porções onde o sinal tem maior amplitude, provavelmente associados a materiais com resistividade elétrica mais elevada. No entanto, não são observadas atenuações do sinal que sejam claramente correlacionáveis a contaminações pretéritas. Parte de um perfil à jusante da vala neste levantamento pode ser visto na Figura 32.

A Figura 33 mostra em planta o resultado do levantamento executado no mês de agosto de 2008, estando marcado o local onde seria implantada posteriormente a vala. 
Existe um alinhamento longitudinal na área com maior amplitude de sinal na cor magenta, que se pode correlacionar a materiais não condutivos.

Essa feição também aparece de maneira clara a leste da área e de maneira mais dispersa a sul, próxima dos limites com a Lagoa Seca. Já na porção central notam-se áreas onde a resposta teve menor amplitude de sinal.

Nos levantamentos por georradar não foi definida na porção norte da área a anomalia de alta condutividade detectada pelo método eletromagnético. Como se pode ver nos resultados no Anexo III e na Figura 34, na porção norte ocorrem áreas com amplitude de sinal alto a profundidades menores.

Já na maior profundidade apresentada (5,75m), não fica tão evidente a presença de elementos que produzem maior amplitude de sinal, mas a qualidade do resultado pela baixa penetração do sinal não permite afirmar com certeza que ocorram materiais mais condutivos. Especialmente na campanha de abril de 2009, o resultado a essa profundidade é muito afetado pela elevação do nível freático, que impede a penetração do sinal originando um mapa onde mal se podem individualizar as feições existentes.

Além disso, durante o levantamento de campo, este método é o mais prejudicado nos levantamentos pela presença dos poços cacimba, pois não se pode arrastar a antena sobre a tampa do poço, elevada em $30 \mathrm{~cm}$ do chão, nem sobre os restos da escavação. Estas interferências influenciam menos acentuadamente o levantamento eletromagnético e caminhamento elétrico. 


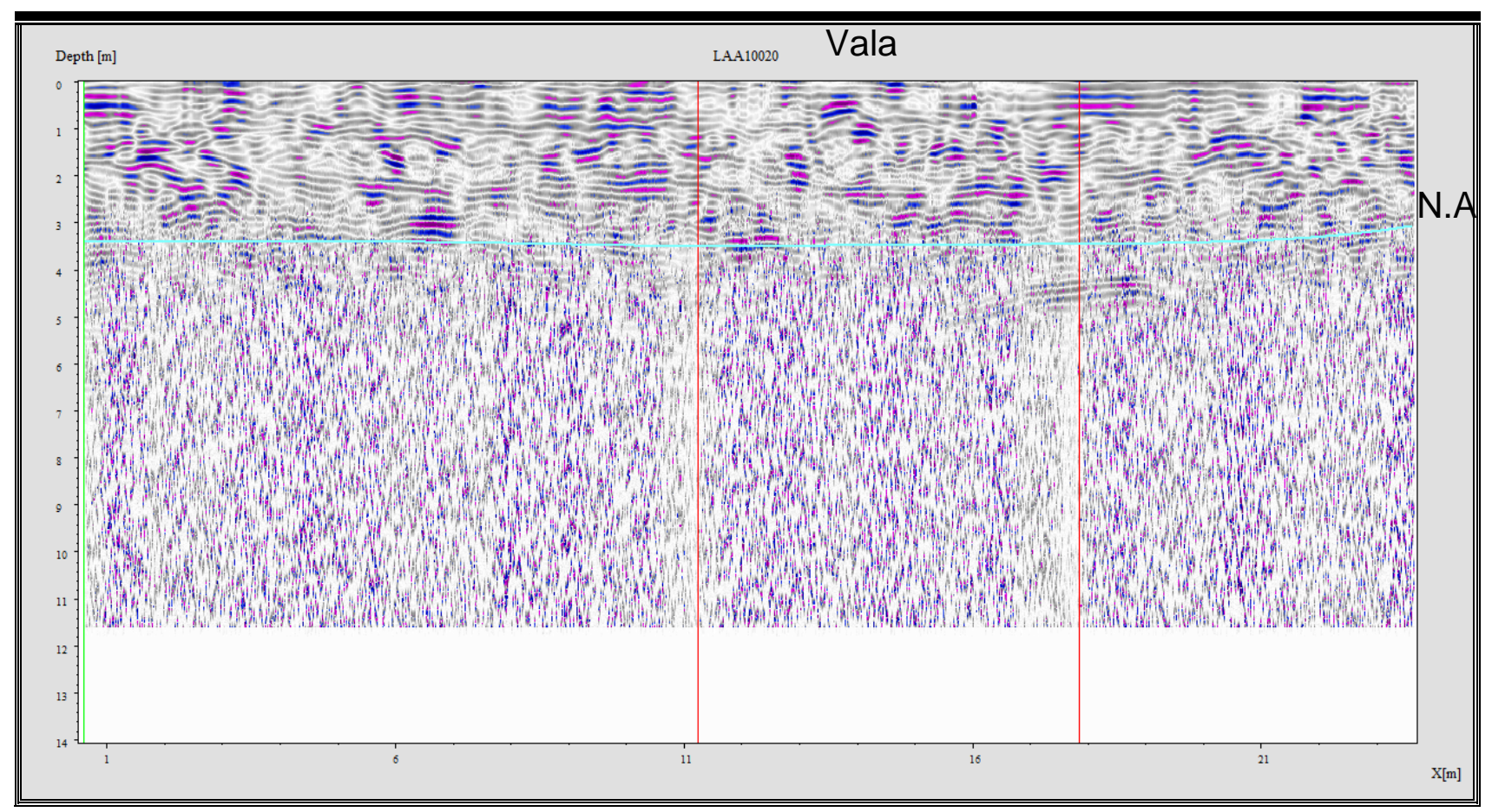

Figura 32 - Perfil de georradar 2D da linha 18 executada em agosto de 2008. As áreas com cores fortes magenta/azul representam maior amplitude de sinal. As linhas vermelhas mostram os limites da futura vala e a linha azul clara o nível do freático (N.A.) inferido do levantamento.

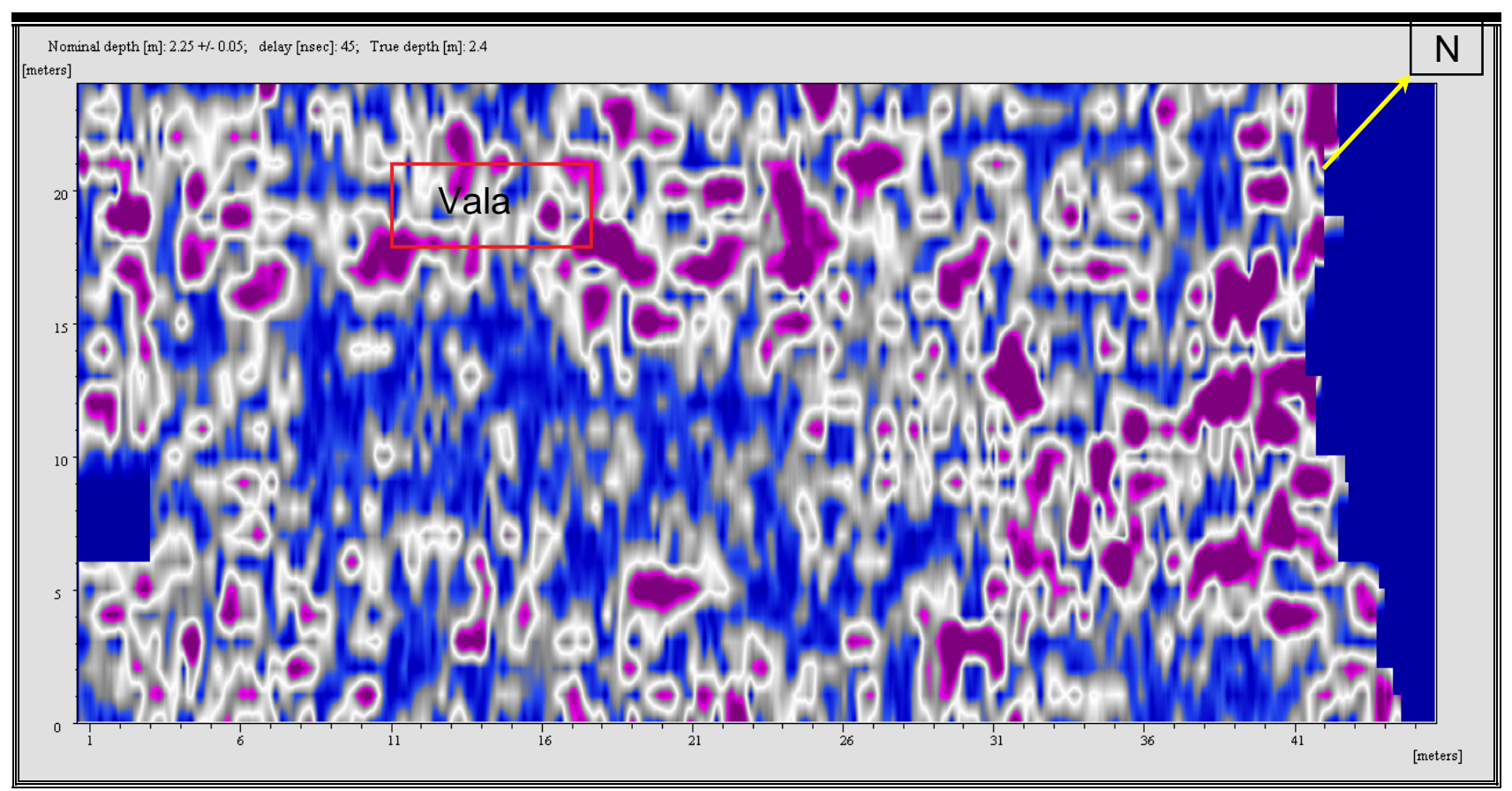

Figura 33 - Mapa de georradar na profundidade de 2,4 m em agosto de 2008. 
Em todas as etapas durante os levantamentos, a presença de raízes expostas ou outros obstáculos fez com que, apesar do cuidado na aquisição, a antena de afastasse do contato com o solo, provocando a perda do sinal desde a superfície do solo. O que se espera no caso de uma atenuação por contaminação, é que a atenuação se acentuasse à profundidade do contaminante, no caso do experimento, a cerca de $2,5 \mathrm{~m}$ de profundidade (fundo da vala) ou à profundidade do freático para cada etapa de campo.

Os tratamentos das seções de georradar obtidas foram feitos com base em conhecimento prévio de campo, ou seja, da localização da vala e do sentido do fluxo subterrâneo. O tratamento sem estas informações não permitiu reconhecer a área do experimento em uma primeira tentativa, pois não se obtiveram resultados que indicassem nitidamente estas feições objeto da pesquisa.

Considerando este fato, analisando os resultados para o nível 3,2m, nota-se que em agosto de 2008 na área da vala o material presente apresenta amplitude alta, havendo uma diminuição desta amplitude no levantamento seguinte e em abril de 2009. Entretanto, em fevereiro de 2009 o resultado, apesar da presença dos corpos de animais, mostra também amplitude elevada no interior da área da vala.

Para o nível investigado de 3,95m, alguns levantamentos e, em especial o resultado de fevereiro de 2009, parecem indicar áreas com atenuação de sinal no sentido do fluxo subterrâneo. Entretanto, como foi dito, existem resultados similares em outros pontos da área que não têm ligação com a vala e a migração do necrochorume gerado.

Da mesma forma, na análise dos mapas para a profundidade de 5,75m não é possível estabelecer uma correlação clara entre o experimento e o resultado do georradar, apenas insinuações de um padrão de ligação.

As atenuações e hipérboles encontradas não se correlacionam com anomalias originadas dos outros levantamentos, já que seria razoável supor que anomalias presentes de origem geológica ou hidrogeológica se repetissem ou provocassem resposta semelhante nos resultados dos métodos utilizados.

Hipérboles abertas encontradas estão ligadas a elementos naturais, tais como formigueiros ou tocas de tatu, o que foi confirmado com execução de furo com trado sobre um destes locais, sendo confirmada a existência de vazio de $20 \mathrm{~cm}$ de diâmetro. A 
presença de dutos enterrados foi descartada pelo histórico da área e pela não continuidade das hipérboles em seções vizinhas.

\subsubsection{Caminhamento Elétrico}

Os resultados obtidos pelo método da eletrorresistividade se mostraram condizentes com os citados em outros trabalhos e, pelo espaçamento utilizado entre eletrodos do dipolo, com bom detalhamento dos perfis obtidos.

Em profundidades mais rasas, apesar da clara determinação do local da vala, não foram obtidos resultados associados à formação do necrochorume, fato que concorda com a profundidade da colocação dos corpos na vala e do nível freático.

Nas Figuras 34 e 35 é possível se determinar com clareza, a jusante da vala, regiões de maior resistividade, junto aos poços PM 2 a PM 9 com coloração alaranjada. Nestas etapas, estes locais deveriam sofrer aumento da condutividade pela presença de sais provenientes dos corpos se a contaminação migrasse a essa profundidade.

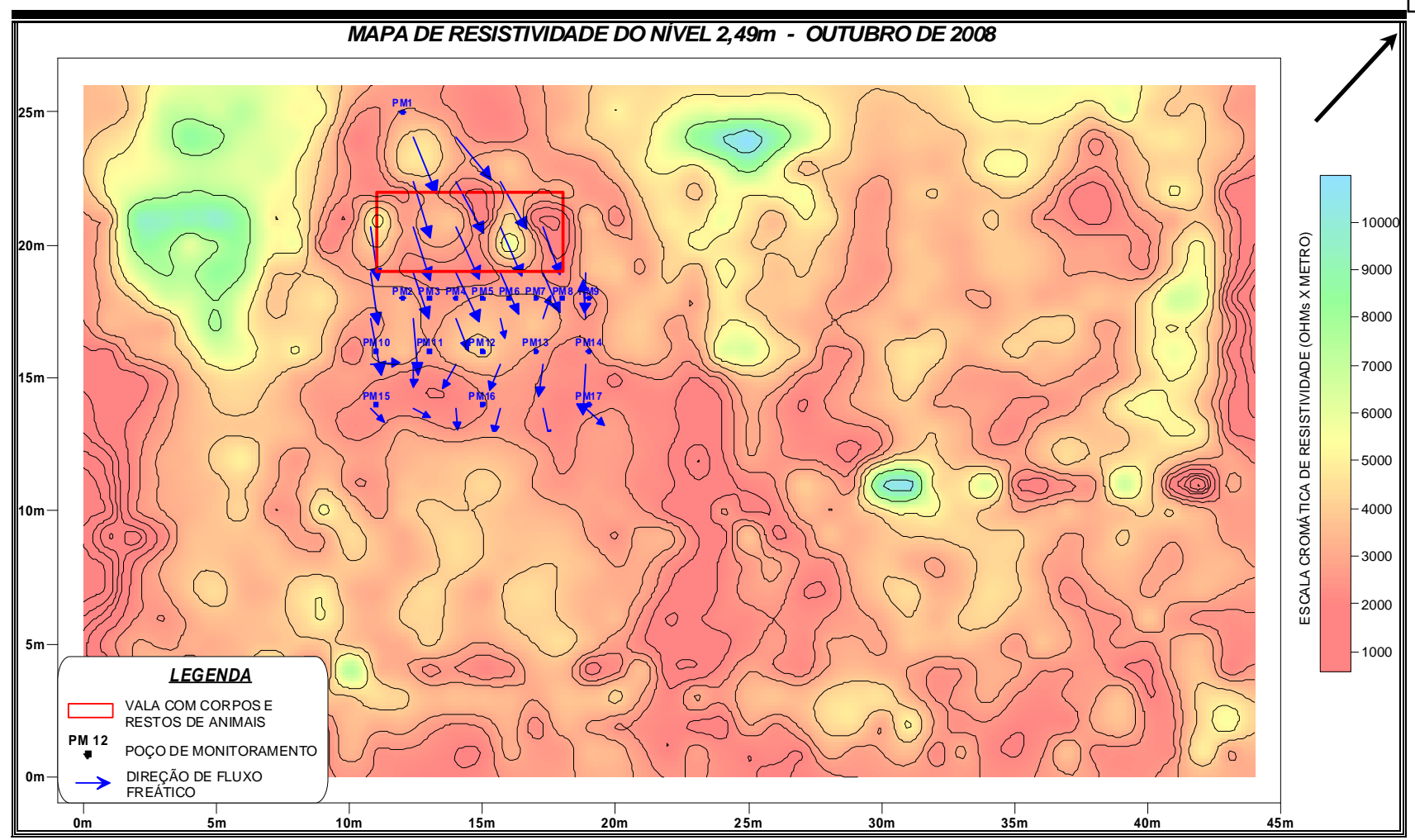

Figura 34 - Mapa de resistividade do nível 2,49m em outubro de 2008. 


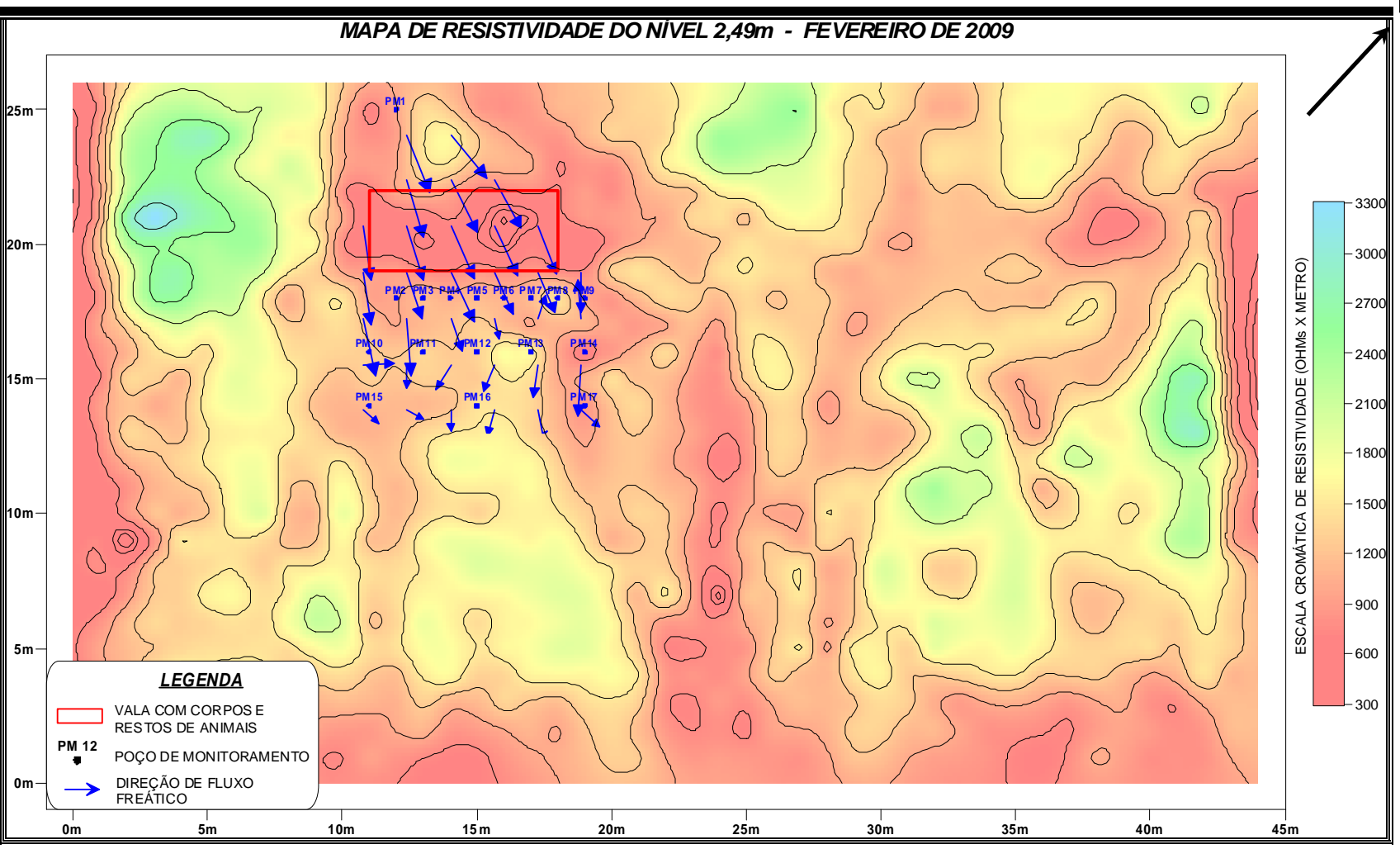

Figura 35 - Mapa de resistividade do nível 2,49m em fevereiro de 2009.

Analisando-se os mapas do Anexo IV, nota-se que em todas as profundidades apresentadas, o resultado da campanha de agosto de 2008 mostra no local onde se colocaria posteriormente a vala, um padrão de elevada resistividade, atingindo valores da ordem de $10^{4}$ Ohms x metro.

$\mathrm{Na}$ campanha de outubro de 2008 á profundidade de 2,49m, é muito clara a redução da resistividade no local da vala instalada e a migração do freático enriquecido em sais na direção do fluxo subterrâneo, representado pelas setas azuis. Essa anomalia tende a aumentar nas campanhas posteriores de fevereiro e abril de 2009, não sendo mascarada com a elevação do nível freático, especialmente na última campanha.

Também na profundidade de 3,96m, a partir da campanha de outubro de 2008, é possível delimitar a área dentro da cava onde se dá a migração vertical do líquido gerado e também acompanhar a migração da pluma concordante com o sentido de fluxo indicado pela potenciometria da área.

Nesta profundidade de 3,96m no levantamento de outubro de 2008 nota-se ainda que na porção norte da vala ocorre material com maior resistividade elétrica e 
possivelmente menos poroso, não permitindo a migração vertical do necrochorume formado, representado pela coloração verde a amarela. Essa feição se repete com intensidade também nos levantamentos de fevereiro e abril de 2009.

$\mathrm{Da}$ análise dos mapas gerados para a profundidade de $5,75 \mathrm{~m}$ nota-se para o interior da vala a presença de material de resistividade elétrica relativamente maior e, a jusante da vala, a presença de pluma de contaminantes mais suave, migrando em direção à Lagoa Seca, porém com seus valores de resistividade elétrica se confundindo com os obtidos para o meio saturado.

Os resultados das análises físico-químicas não mostraram alterações que permitissem associar variações na resistividade do meio analisado por este método. Entretanto, deve-se lembrar que, dentre as hipóteses levantadas para tal comportamento, há a possibilidade do contaminante gerado ter migrado por profundidades maiores e, por isso, não ter sido a amostragem da água não ter sido adequadamente coletada nos poços de monitoramento, como já mencionado.

Os resultados obtidos por este método geofísico corroboram esta hipótese, mostrando claramente a migração do líquido gerado a partir da profundidade de 3,2m até pelo menos $5,75 \mathrm{~m}$, cerca de dois metros abaixo do nível do freático.

$\mathrm{Na}$ área da vala ocorre uma continuidade vertical da anomalia, desde a relacionada à vala em si a partir da superfície, pela remobilização do solo e inserção dos corpos, até mais de 5 metros de profundidade. A Figura 36 mostra essa situação através do resultado das pseudo-seções originadas pelo tratamento dos dados da linha 20 , sobre a vala, no levantamento efetuado em fevereiro de 2009. 


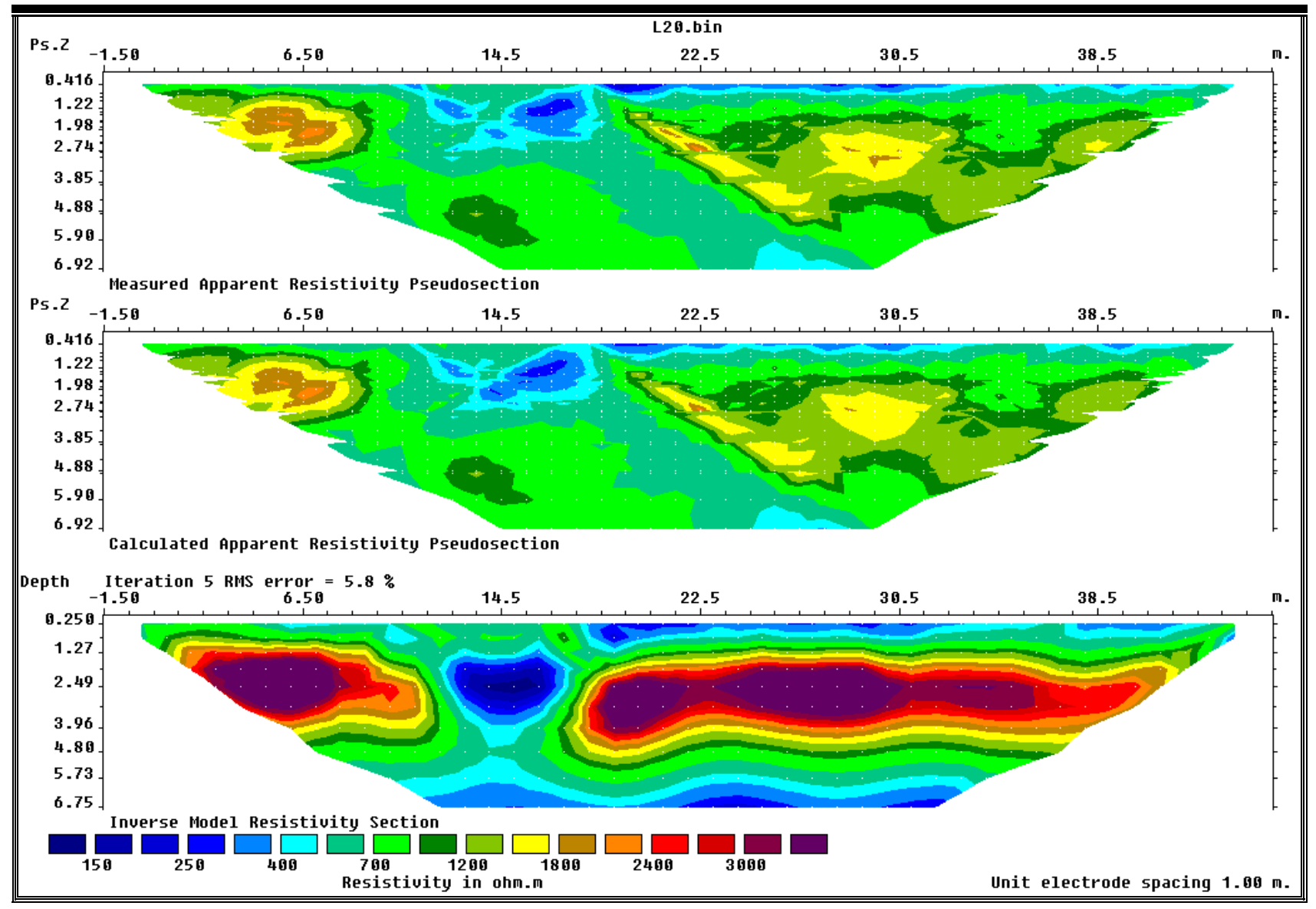

Figura 36 - Pseudo-seções de resistividade com os dados de campo, modelo inicial e modelo final, respectivamente de cima para baixo na figura. 


\section{Conclusões}

Foram implantados corpos e restos de animais em uma vala sem outra alteração no solo para comparação entre três métodos geofísicos propostos, eletromagnético, georradar e resistividade.

Concomitantemente aos levantamentos geofísicos foram efetuadas coletas e análises físico-químicas de água subterrânea, que não indicaram as esperadas alterações originadas pela decomposição dos corpos.

A falta de conhecimento bibliográfico sobre o comportamento de necrochorume no solo e água subterrânea, incluindo sua solubilidade, mobilidade na zona saturada, comportamento iônico e reação ao meio, ocasionou a locação inadequada dos filtros dos poços de monitoramento. Conclui-se, analisando os resultados, que os poços deveriam ser instalados e amostrados em profundidades variáveis, desde a franja capilar até profundidades maiores que as utilizadas neste estudo tendo em vista a provável migração do necrochorume verticalmente devido a sua maior densidade.

Com a coleta de água em várias profundidades e em menores intervalos entre as campanhas, desde a implantação dos corpos, certamente se obteriam resultados correlacionáveis à pluma de contaminação. Com isso seriam possíveis a detecção e delimitação da pluma através das análises físico-químicas.

Desta forma, este experimento implicaria em elevados esforços direcionados para análises físico-químicas e no preparo da área de estudo. Entretanto, este seria um estudo específico da hidrogeoquímica ou da área forense, fora do objetivo deste trabalho.

Apesar disso, no presente estudo, o caminhamento elétrico mostrou ser a melhor ferramenta para a análise do comportamento detalhado da pluma de contaminação originada pela decomposição dos corpos enterrados que, por similaridade, pode também ser aplicado para áreas de cemitérios.

Assim, se considerarmos a instalação de uma malha densa de poços, vários níveis de investigação e a coleta e análise de amostras destas águas, conclui-se que o custo com que se obtêm resultados similares, é muito menor com a aplicação do método da eletrorresistividade. 
Desconsiderando-se a construção dos poços, o tempo utilizado na coleta de dados geofísicos é maior que o gasto em uma campanha de coleta de amostras. Entretanto, quando se compara o tratamento dos resultados geofísicos, a análise química das amostras e posterior interpretação dos resultados, conclui-se que novamente o método indireto com essa técnica é mais rápido que o método direto das análises físico-químicas.

$\mathrm{Na}$ análise inicial, o levantamento do Potencial Espontâneo (SP) mostrou resultado das direções de fluxo subterrâneo da área contrários ao previsto, o que foi efetivamente confirmado pelas medições nos poços de monitoramento. Este resultado deve ser checado em pesquisas posteriores para se determinar em que condições isso pode ocorrer.

Os outros métodos geofísicos testados (Georradar e EM) não se mostraram adequados às condições da pesquisa efetuada, quer por não atingirem a profundidade necessária para detecção da contaminação, quer por não apresentarem resolução na configuração utilizada para esta deteç̧ão, a despeito de bons resultados relatados na bibliografia.

O fato de o método eletromagnético ter detectado a anomalia de alta condutividade elétrica na porção norte da área, mas o mesmo não ter sido detectado no resultado do caminhamento elétrico, apesar do maior detalhamento deste último, se explica ou pelo aparente caráter superficial da anomalia, ou pela configuração do arranjo dipolo-dipolo onde, nos últimos pontos medidos em cada linha, apenas os níveis mais próximos da superfície são efetivamente levantados.

Em relação ao georradar, com excelentes resultados na bibliografia levantada tanto em pesquisas forenses como em outras aplicações ambientais, conclui-se que apenas por se conhecer previamente o local da vala e o sentido de fluxo subterrâneo foi possível dar o tratamento adequado aos dados e se obter algum resultado, mesmo assim com pouca definição. Nas condições da pesquisa, sem conhecimento prévio do alvo localização, profundidade e fluxo dos contaminantes - seria improvável obter resultados adequados, contrariamente ao que ocorre com o uso da eletrorresistividade.

Diante dos resultados obtidos neste projeto de pesquisa, a eletrorresistividade, particularmente com o caminhamento elétrico, mostrou ser o método mais eficaz e que alcançou plenamente o objetivo proposto. 


\section{Referências Bibliográficas}

ALMEIDA, F. F. M. Fundamentos geológicos do relevo Paulista. Boletim Instituto Geografico e Geológico, São Paulo, n. 41, p.169-263, 1964.

ALMEIDA, M DE A.; MACEDO, J. A. B. Parâmetros físico-químicos de caracterização da contaminação do lençol freático por necrochorume. In: Seminário de Gestão Ambiental Um convite à Interdisciplinaridade. Instituto Vianna Júnior. Juiz de Fora, MG. 2005.

APPARAO, A.; GANDHARA, R. T.; SIVARAMA R. S., SARMA, V. S. Depth detection of buried conductive targets with different electrode arrays in resistivity prospecting. Geophysical Prospecting, v. 40, p.749-760, 1992.

APPARAO, A.; SIVARAMA R. S.; SUBRAHMAYA, V. S. Depth detection of buried resistive targets with some electrode arrays in electrical prospecting. Geophysical Prospecting, v. 45, p.365-375, 1997.

ARCHAEO-PHYSICS Location of human burials: case study using gpr and eletrical resistance survey. Disponível em: <www.archaeophysicis.com/burials>. Acesso em 16 ago. 2005 .

ASMUS, H. E.; FERRARI, A. L. Hipótese sobre a causa do tectonismo cenozóico na região sudeste do Brasil: aspectos estruturais da margem continental leste e sudeste do Brasil. Rio de Janeiro: PETROBRÁS. (Série Projeto REMAC, n. 4) , p. 75-88, 1978.

ARISTODEMOU, E.; THOMAS-BETTS, A. DC resistivity and induced polarization investigations at a waste disposal site and its enviroments. Journal of Apllied Geophysics, v. 44, p. 275-302, 2000.

BAPTISTA, M. B.; BRAUN, O. P. G.; CAMPOS, D. A. Léxico estratigráfico do Brasil. Brasília: DNPM-CPRM, 560 p. 1984.

BARKER R. D. Depth of investigation of collinear symmetrical four-electrode arrays. Geophysics, v. 54, n. 8, p. 1031-1037, 1989.

BASTIANON, D.; MATOS, B. A.; AQUINO, W. F.; PACHECO, A.; MENDES, J. M. Geophysical surveying to investigate groundwater contamination by a cemetery. In: Symposium on the Application of Geophysics to Engineering and Environmental Problems, Arlington, VA, U.S.A. Proceedings. Arlington: Environmental and Engineering and Geophysical Society, p. 709-718. 2000.

BELLO, L. A. L., SADALLA NETO, S. F.; SANTOS FILHO, W. M. Geoenvironmental investigations for cemetery installation and its impact on the environment. In: International Congress on Environmental Geotechnics, 4., Rio de Janeiro. Anais... Rotterdam: Balkema. v. 1, p. 271-276, 2002.

BENTLEY, L. R.; TRENHOLM, N. M. The accuracy of water table elevation estimates Determined from ground penetrating radar data. Journal of Environmental \& Engineering Geophysics, v. 7, n. 1, p.37-53, 2002.

BERES JR., M. ; HAENI, F. P. Application of ground penetrating radar methods in hidrogeologic studies. Ground Water, v. 29, n. 3, p.375-386, 1991.

BEVAN, B. W. The search for graves. Geophysics, v. 56, p. 1310-1319, 1991. 
BJORNBERG, A. J. S.; LANDIM, P. M. B.; MEIRELLES FILHO, G. M. Restos de plantas modernas em níveis elevados na região de Rio Claro (SP). Publicação Escola Engenharia de São Carlos ,n. 106, p. 37-57,1968.

BOWER, H. Groundwater Hydrology. New York: MacGraw Hill, 480 p, 1978.

BRAGA, A. C. O. A Geofísica aplicada na caracterização da geologia e da qualidade das águas subterrâneas. In: MAIA, N. B. ; LESJAK, H. M.; BARRELLA, W. (Org.). Indicadores Ambientais: conceitos e aplicações. São Paulo: EDUC, v. 1, p. 187-204, 2001.

BRATUS A.; YABAR D. N. Characterization of three different waste disposals using resistivity and IP methods. In:.. Congresso Internacional da Sociedade Brasileira de Geofísica, 7. Salvador. Anais... Salvador: Sociedade Brasileira de Geofisica, p. 216-219. 1 CD-ROM. 2001.

BREWSTER M. L.; ANNAN A. P. Ground penetrating radar monitoring of a controlled DNAPL release: $200 \mathrm{MHz}$ radar. Geophysics, v.59, n.8, p.1211-1221, 1994.

CAETANO-CHANG, M. R. A formação Pirambóia no centro leste do estado de São Paulo. Tese (Livre Docência) - Instituto de Geociências, Universidade de São Paulo, São Paulo, 204 p, 1997.

CAETANO-CHANG, M. R.; WU. F. T.; BRIGUETTI, J. M. P. Caracterização eólica de arenitos da Formação Pirambóia, proximidades de São Pedro (SP). In: Simpósio de Geologia do Sudeste, 2., São Paulo. Atas. São Paulo :SBG, p. 53-58, 1991.

CAETANO-CHANG, M. R.; WU, F. T. Bacia do Paraná: formações Pirambóia e Botucatu. In: Congresso Brasileiro de Geologia, 37., São Paulo. Roteiro de Excursão. São Paulo: SBG, v. 2. 1992.

CARDIMONA, J. S.; CLEMENT, W. P.; KADINSKY-CADE, K. Seismic reflection and ground penetrating radar imaging of a shalow aquifer. Geophysics, v. 63, n. 4, p.13101317, 1998.

CARVALHO Jr., M. A. F.; COSTA E SILVA, L. M. SP e eletrorresistividade aplicados ao estudo hidrogeológico de um cemitério. In: Congresso Internacional da da Sociedade Brasileira de Geofísica, V, São Paulo. Anais... São Paulo: SBGf, v. 1, p. 471-4, 1997.

CASTRO, D. L.. Caracterização geofísica e hidrogeológica do Cemitério Bom Jardim, Fortaleza - CE. Revista Brasileira de Geofísica, V 2693, p. 251-271, 2008.

CETESB - Companhia de Tecnologia e Saneamento Ambiental do Estado de São Paulo. Norma Técnica 1040/99. Implantação e Operação de Cemitérios, 7 p, 1999.

COGGON, J. H. A comparison of IP electrode arrays. Geophysics, v. 38, n. 4, p. 737-761, 1973.

COTTAS, L. R. Estudos geológico-geotécnicos aplicados ao planejamento urbano de Rio Claro (SP). Tese (Doutorado) - Instituto de Geociências, Universidade de São Paulo, São Paulo, 171p, 1983.

DAVIS, J. L.; ANNAN, A. P. Ground penetrating radar for high-resolution mapping of soil and rock stratigraphy. Geophysical Prospecting, v. 37, n. 5, p. 531-551, 1989.

DENT, B. B.; FORBES, S. L.; STUART, B. H. Review of human decomposition processes in soil. Environmental Geology. V 45: 576-585. 2004 
DOBECKI, T. L.; ROMIG, P. R. Geotechnical and groundwater geophysics. Geophysics, v. 50, n. 12, p. 2621-2636, 1985.

DURÃES, N.; CORTEZ, D.; ALGARRA, M.; SÁNCHEZ, F. G.; RODRIGUES-BORGES, J. E.; BOBOS, I.; SILVA, J. C. G. E. Comparasion of adipocere formation in four soil types of the Porto (Portugal) District. Forensic Science International. Elsevier Ireland. V. 195 168.e1-168. e6. 2009.

EDWARDS, L. S. A modified pseudosection for resistivity and IP. Geophysics, v. 42, n. 5, p.1020-1036, 1977.

ELIS, V. R. Avaliação da aplicabilidade de métodos elétricos de prospecção geofísica no estudo de áreas utilizadas para disposição de resíduos. Tese (Doutorado) - Instituto de Geociências e Ciências Exatas, Universidade Estadual Paulista, Rio Claro/SP, 264p, 1998.

ENDRES, A. L.; CLEMENT, W. P.; RUDOLPH, D. L. Ground penetrating radar imaging of a aquifer during a pumping test. Ground Water, v. 38, n. 4, p. 566-576, 2000.

ENVIRONMENTAL AGENCY. Assessing the groundwater pollution potencial of cemetery developments. Science Group: Air, Land \& Water.Bristol, UK. 2004

FERREIRA, S. R. Análise pedoestratigráfica das formações Rio Claro e Piraçununga, no centro-leste do Estado de São Paulo. (Tese DOUTORADO) - Instituto de Geociências e Ciências Exatas, Universidade Estadual Paulista, Rio Claro/SP, 157p, 2005.

FIELDER, S.; SCHNECKNBERGER, K.; GRAW, M. Characterization of Soils containing adipocere. Archives of Environmental Contamination and Toxicology. Springer. 47: 561568. 2004.

FORBES, G. B. Human Body Composition: growth, aging, nutrition and activity. New York: Springer-Verlag. 523 p,1987.

FOX, R. C.; HOHMANN, G. W.; KILLPACK, T. J.; RIJO, L. Topographic effects in resistivity and induced-polarization surveys. Geophysics, v. 45, n. 1, p. 75-93, 1980.

FREELAND, R. S.; MILLER, M. L.; YODER, R. E.; KOPPENJAN, S. K. Forensic application of FM-CW and pulse radar. Journal of Environmental and Engineering Geophysics, v. 8, n. 2, p. 97-103, 2003.

FREITAS, R. O.; MEZZALIRA, S.; ODA, G. H.; VIEIRA, P. C.; TORRES, C. C.; HACHIRO, J .; TOMINAGA, L. K.; DEHIRA. L.; MASSOLINI, M.; AZEVEDO, A. A. B.; PRESSIONTI, M. M. N. Projeto levantamento geológico de formações superficiais.In:... Simpósio Regional de Geologia, 2., Rio Claro. Atas...Rio Claro: SBG, v.2, p.263-277, 1979.

FREITAS, R. O.; VIEIRA. P. C.; MEZZALIRA, S. A Formação Pirassununga na região de Vargem Grande do Sul (SP): aplicação da técnica de perfis sedimentares. Revista do Instituto Geológico, São Paulo, v. 11, n. 2, p. 35-48, 1990.

FÚlFARO. V. J.; SUGUIO, K. A Formação Rio Claro (neo-ceozóico) e seu ambiente de deposição. Boletim Instituto Geográfico e Geológico, São Paulo, n. 20, p. 45 - 60, 1968.

FÚlFARO. V. J.; SUGUIO, K. O Cenozóico paulista: Gênese e idade. In: Congresso Brasileiro de Geologia, 28., Porto Alegre, Anais... Porto Alegre: SBG, v. 3, p. 91-101, 1974. 
GALLAS, J. D. F. Principais métodos geoelétricos e suas aplicações em prospecção mineral, hidrogeologia, geologia de engenharia e geologia ambiental. Tese (Doutorado em Geociências e Meio Ambiente) - Instituto de Geociências e Ciências Exatas, Universidade Estadual Paulista. Rio Claro/SP, 174p, 2000.

GALLAS, J. D. F. Método eletromagnético. São Paulo:. (Apostila da Disciplina Geofísica Aplicada). Instituto de Geociências da Universidade de São Paulo. 7 p. 2007.

GALLAS, J. D. F.; BIRELLI, C. A. Levantamentos geofísicos em área de ampliação do cemitério municipal São Sebastião em Rio Grande da Serra, SP - Interessado: Secretaria da Ciência, Tecnologia e Desenvolvimento Econômico do Estado de São Paulo - SCTDE. 1993. (Relatório IPT-31.630)

GALLAS; J. D. F.; TAIOLI; F.; MALAGUTTI FILHO, W.; PRADO, R. L.; DOURADO, J. C. Métodos e técnicas geoelétricas rasas na delimitação de área afetada por ruptura em teto de túnel urbano. Revista Brasileira de Geofísica, São Paulo, v.19 n.1, 2001.

GALLAS, J. D. F.; TAIOLI, F.; MALAGUTTI FILHO, W. Comparison between Induced Polarization and Resistivity and the use of SP to evaluate contamination due to landfill leakage. Journal of Applied Geophysics. 2010. versão on line.

GALLAS, J. D. F., TAIOLI, F., SILVA, S. M. C. P. DA ; COELHO, O. G. W. ; PAIM, P. S. G. Contaminação por chorume e sua detecção por resistividade. Revista Brasileira de Geofísica, v. 25, n. 1, p. 51-59, 2005.

GANDOLFO, O. C. B. Um estudo do imageamento geoelétrico na investigação rasa. Tese (Doutorado em Geociências, Recursos Minerais e Hidrogeologia) - Instituto de Geociências, Universidade de São Paulo, São Paulo, 215p, 2007.

GREENHOUSE, J. P. Environmental geophysics: it's about time. Geophysics, v. 10, n. 1, p. 32-34, 1991.

HACHIRO, J. Litotipos, associações, faciológicas e sistemas deposicionais da Formação Irati no Estado de São Paulo. Dissertação (Mestrado) - Instituto de Geociências, Universidade de São Paulo, São Paulo, 175p, 1991.

IPT INSTITUTO DE PESQUISAS TECNOLÓGICAS. Mapa geológico do Estado de São Paulo, São Paulo, 1981. 2 mapas. Escala 1:500.000 (Série Monografias).

JOHNSON, D. G. Use of ground penetrating radar for water-table mapping,.Brewster and Harwich, Massachusetts. Marlborough: U.S.Geological Survey, Water-Resources Investigations Report 90-4086, 27 p, 1992.

KELLER, G.; FRISCHKNECHT, F.. Electrical methods in geophysical prospecting. Pergamon Press, 1966.

LANDIM, P. M. B.; SOARES, P. C.; GAMA, J. R. E. Estratigrafia do noroeste da Bacia Sedimentar do Paraná. Curso de especialização. 1980. 45 p. (Convênio IPT-UNESP Rio Claro)

LIMA, O. A. L.; SATO, H. K. Detecção da contaminação de águas subterrâneas usando técnicas de eletrorresistividade. In:... Congresso Internacional da Sociedade Brasileirad e Geofísica, 3., Rio de Janeiro. Resumos Expandidos... Rio de Janeiro: SBGf, v.I, p.216219, 1993. 
LOKE, M. H.; BARKER, R. D. Least-squares deconvulation of apparent resistivity pseudosections. Geophysics, v. 60, n. 6, p.1682-1690, 1995.

LOKE, M. H.; BARKER, R. D. Rapid least-squares inversion of apparent resistivity pseudosections by a quasi-Newton method. Geophysical Prospecting, v. 44, p.131-152, 1996.

MAILLET, R.. The fundamental equations of electrical prospecting, Geophysics. Vol. 3, pp. 529-556, 1947.

MATOS, B. A. Avaliação da ocorrência e do transporte de microorganismos no aqüífero freático do cemitério de Vila Nova Cachoeirinha, Município de São Paulo. Tese

(Doutorado) - Instituto de Geociências da Universidade de São Paulo, São Paulo, 171p, 2001.

MARINHO, A. M. C. P. Contaminação de aqüíferos por instalação de cemitérios. Estudo de caso do Cemitério São João Batista, Fortaleza. Dissertação (Mestrado) - Centro de Ciências, Universidade Federal do Ceará, Fortaleza, 88p, 1998.

McBRIDE, B. M. Environmental Chemistry of Soils. Oxford, New York, 1 Ed. 406 p,1994.

MENDES, J. M. B.; PACHECO, A.; HASSUDA, S. Cemitérios e meio ambiente - a geofísica como método auxiliar na avaliação de sua influência nas águas subterrâneas. In:... Encontro Nacional de Estudos sobre o Meio Ambiente, 2., Florianópolis. Anais... Florianópolis: UFSC, v. 1, p. 50-57,1989.

MIGLIORINI, R. B. Cemitérios contaminam o meio ambiente? Em estudo de caso. Cuiabá: Editora Universidade Federal de Mato Grosso. 2002. 50 p.

MIGLIORINI, R. B; KIMMELMANN, A. A.; PACHECO, A. Estudo físico-químico das águas subterrâneas do cemitério Vila Formosa, São Paulo, SP. Congresso Brasileiro de Águas Subterrâneas. Recife. Anais, p. 160-168,1994.

MOREIRA, C. A.; DOURADO, J. C.; SANTOS, K. Geofísica aplicada no estudo de área de lançamento de efluentes de tratamento de esgoto. Revista Geociências. UNESP, São Paulo. v. 26, n. 1. p 17-25, 2007.

NASCIMENTO, C. T.; KOIDE, S.; PIRES, A. C. B. Análise geofísica, por meio de GPR, do espalhamento de efluentes de fossa séptica no subsolo. In: $X$ Congresso Brasileiro de Águas Subterrâneas, 10., 1998, São Paulo. Anais... São Paulo: ABAS, 1998. 1 CDROM.

NOBES, D. C. Geophysical surveys at burial sites: a case study of the Oaro Urupá. Geophysicis, v. 64, p. 357-367,1999.

OGILVY, R.; MELDRUM P.; CHAMBERS J.; WILLIAMS G. The use of 3D Electrical Tomography to Characterise Waste and Leachate Distribuition within a Closed Landfill, Thriplow, Uk. Journal of Environmental \& Engineering Geophysics, v. 7, n. 1, p. 11-18, 2002.

ORELlANA, E. Prospección geoelétrica en corriente continua. Madrid: Paraninfo. 523 p, 1972.

PACHECO, A. Cemitérios e meio Ambiente. Tese (Livre Docência) - Instituto de Geociências, Universidade de São Paulo, São Paulo, 102p, 2000. 
PACHECO, A.; MENDES, J. M. B.; MARTINS, T.; HASSUDA, S.; KIMMELMAN, A. A. Cemeteries: a potential risk to groundwater. Water Science and Technology, v. 24, n. 11, p. 97-104, 1991.

PACHECO, A.; SARAIVA, F. A. Os cemitérios em áreas litorâneas: riscos ambientais e higiênicos. In:... Congresso Brasileiro de Pesquisas Ambientais e de Saude, 4., 2004., Santos. Anais... Santos: COPEC, p. 44, 2004.

PACHECO, A.; SARAIVA, F. A. Normas a que deve obedecer a escolha de terrenos para instalação de cemitérios públicos em Portugal: comentários técnicos e licenciamento ambiental. Revista Tecnologias do Ambiente, Lisboa, v. 12, n. 65. p. 12-15, 2005.

PACHECO, A.; SARAIVA, F. A.; BRITES, J. A. DO A. Cemitérios: um risco de contaminação para as águas subterrâneas. Revista Ambiente 21, Lisboa, n. 14, Ano II, p. 52-54, 2004.

PARK, S. Fluid migration in the vadose zone from 3-D inversion of resistivity monitoring data. Geophysics, v. 63, n. 1, p. 41-51, 1998.

PELLERIN, L. Applications of electrical and electromagnetic methods for environmental and geotechnical investigations. Surveys in Geophysics. Kluwer Academic Publishers. 23: 101-132, 2001.

PELUSO, F.; VIVES, L, VARNI, M. ; CAZENAVE, G; CASTELAIN, J. GONZÁLEZ E USUNOFF, E.. Evaluación preventiva espacial del riesgo sanitario por la instalación de un cementerio parque, GeoFocus (Informes y comentarios), n.ำ 6, p. 1-14, 2006.

PEQUENO MARINHO, A. M. C. Cemitérios e a contaminação das águas subterrâneas. In:... Congresso Brasileiro de Saude Conetiva 7., 2003, Brasília. Anais. Rio de Janeiro : ABRASCO, v. 8, supl. 1, p. 399, 2003. ( Poster PT836).

PERSON, J. Interventions Réolementaires du Géologue Agréé em ye de la protection des caux destinées à I alimentation humaine. Document du BRGm, Marseille, Saint Lambert, $193 \mathrm{p}, 1979$.

PRINGLE, J.K. \& JERVIS, J.R. Eletrical resistivity survey to search for a recent clandestine burial of a homicide victim, UK. Forensic Science International. Elsevier Ireland Ltd. 7p, 202. 2010.

PRINGLE, J.K.; CASSELA, J.P.; JERVIS, J.R.. Preliminary Soliwater conductivity analysis to date clandestine burials of homicide victims. Forensic Science International, 202. Elsevier Ireland Ltd. 198 p. 126-133,2010.

REYNOLDS, J. M. 1997. An Introduction to Applied and Environmental Geophysics, John Wiley and Sons Ltd, Chichester, $796 \mathrm{pp}$.

RODRIGUEZ, W. C. III \& W. M. BASS. Decomposition of buried bodies and methods that may aid in their location. Journal of Forensic Sciences 30: 836-852, 1985.

ROY, A.; APPARAO, A. Depth of investigation in direct current methods. Geophysics, v. 36, n. 5, p. 943-959, 1971.

SCHOOR, M. van. Detection of sinkholes using 2D electrical resistivity imaging. Journal of Applied Geophysics, v. 50, p. 393-399, 2002. 
SCHNEIDER, R.L.; MÜHLMANN, H.; TOMMASI, E.; MEDEIROS, R. A.; DAEMON, R. F.; NOGUEIRA, A. A. Revisão estratigráfica da Bacia do Paraná. In: Congresso Brasileiro de Geologia, 28, Porto Alegre, 1974. Anais ... Porto Alegre : SBG , v. 1, p.41-65, 1974.

SEATON, W. J.; BURBEY T. J. Evaluation of two-dimensional resistivity methods in a fractured crystalline-rock terrain. Journal of Applied Geophysics, v. 51, p.21-41, 2002.

SENOS MATIAS, M. J.; MARQUES DA SILVA, M.; GONÇALVES, L.; PERALTA, C.; GRANJEIA, C.; MARTINHO , E. An Investigation into the use of geophysical methods in the study of aquifer contamination by graveyards. Near surface geophysics. European Association of Geoscientists \& Engineers, p. 131-136. 2004.

SILVA, L. M. Cemitérios: fonte potencial de contaminação do lençol freático. Publicação Especial da Faculdade São Judas Tadeu, São Paulo, 2000.

SILVA, R. W. da C; MALLAGUTTI FILHO, W. Emprego do imageamento elétrico no estudo da contaminação por cemitérios. São Paulo, UNESP, Geociências, v. 29, n. 3, p. 343-354, 2010.

SOARES, P. C., LANDIM, P. M. B. Depósitos cenozóicos na região centro sul do Brasil. Notícia Geomorfológica, Campinas, v. 16, n. 31, p 17-39, 1976.

SPONGBERG, A. L.; BECKS, P. Inorganic soil contamination from cemetery leachate. Water, Air and Soil Pollution. Kluwer Academic Publishers. v. 117, p. 313-327. 2000.

STEEPLES, D. W. Uses and techniques of environmental geophysics. Geophysics: the leading edge of exploration, v. 10, n. 9, p. 30-31, 1991.

TAIOLI, F.; SARAIVA, F. A. Levantamento geofísico por eletrorresistividade ao longo da Rua Alexandre Dias, Sub-Prefeitura de Itaquera, São Paulo. São Paulo: Secretaria do Verde e Meio Ambiente do Município de São Paulo. 23 p, 2004. (Relatório Técnico).

TELFORD, W. M.; GELDART, L. P.; SHERIF, R. E. Applied geophysics. 2. ed. Cambridge: Cambridge University Press, 770 p, 1990.

TONG, L.; YANG, C. Incorporation of topography into two-dimensional resistivity inversion. Geophysics, v. 55, p. 354-361,1990.

TREDOUX, G.; CAVÉ, L.; ENGELBRECHT, P. Groundwwater pollution: Are we monitoring appropriate parameters?. Water SA. Vol. 30 N. 5 (Special Edition). p 662-667, 2004.

ÜÇISIK, A. S. AND RUSHBROOK, P. The impact of cemeteries on the environment and public health: An Introduction Briefing. World Health Organization, Copenhagen. 1998

VIEIRA, P. C. Geologia da Folha de Rio Capetinga. Revista do Instituto Geológico, São Paulo, v. 3, n. 2, p. 23-52, 1982.

WARD, S. H., Resistivity and induced polarization methods. Geotechnical and environmental Geophysics. Society of Exploration Geophysicists, v.1: Review and Tutorial, p.147-89, 1990.

WU, F. T. Minerais pesados das seqüências arenosas Paleozóicas e Mezozóicas do centro- leste do estado de São Paulo. Dissertação (Mestrado) - Instituto de Geociências, Universidade de São Paulo , São Paulo, 129p, 1981 
WU, F. T. Proveniência das rochas arenosas do Subgrupo Itararé no Sul do Estado de São Paulo, SP. Tese (Doutorado) - Instituto de Geociências e Ciências Exatas, Universidade Estadual Paulista, Rio Claro, 165p, 1989.

YOUNG, C. P.; BLACKMORE, K. M.; REYNOLDS, P. J.; LEAVANS, A. Pollution potential of cemeteries, R\&D Technical Report P223, Environment Agency, ISBN 1857050215. 61 p, 1999.

YOUNG, R. A.; SUN, J. 3D Ground penetrating radar imaging of a shallow aquifer at Hill Air Force Base, Utah. Journal of Environmental \& Engineering Geophysics, v. 1, n. 2, p. 97-108, 1996.

ZAINE, J. E. Geologia da Formação Rio Claro na folha Rio Claro (SP). Dissertação (Mestrado em Geociências) - Instituto de Geociências e Ciências Exatas, Universidade Estadual Paulista, Rio Claro/SP, 90p, 1994. 
ANEXO I

PLANILHAS DE ANÁLISES

FÍSICO-QUÍMICAS 
Resultados de Análise de Fosfato, em mg/L.

\begin{tabular}{|r|r|c|c|c|}
\hline & ago/08 & out/08 & fev/09 & abr/09 \\
\hline PM 1 & 0,02572 & 0,00464 & 0,02133 & 0,00246 \\
\hline PM 2 & 0,02096 & 0,00419 & 0,02155 & 0,00261 \\
\hline PM 3 & 0,02252 & 0,00423 & 0,04667 & 0,00743 \\
\hline PM 4 & 0,01968 & 0,00472 & 0,05062 & 0,00408 \\
\hline PM 5 & 0,02205 & 0,00426 & 0,03991 & 0,00279 \\
\hline PM 6 & 0,02109 & 0,00506 & 0,03883 & 0,00933 \\
\hline PM 7 & 0,02439 & 0,00431 & 0,04422 & 0,00329 \\
\hline PM 8 & 0,02456 & 0,00427 & 0,03411 & 0,00269 \\
\hline PM 9 & 0,02245 & 0,00396 & 0,02255 & 0,00291 \\
\hline PM 10 & 0,02132 & 0,00451 & 0,02088 & 0,00447 \\
\hline PM 11 & 0,02577 & 0,00467 & 0,02300 & 0,00476 \\
\hline PM 12 & 0,02307 & 0,00414 & 0,01887 & 0,00369 \\
\hline PM 13 & 0,02211 & 0,00423 & 0,01904 & 0,00529 \\
\hline PM 14 & 0,02464 & 0,00450 & 0,02484 & 0,00461 \\
\hline PM 15 & 0,02996 & 0,00435 & 0,02074 & 0,00404 \\
\hline PM 16 & 0,02337 & 0,00461 & 0,01761 & 0,00382 \\
\hline PM 17 & 0,02253 & 0,00393 & 0,01996 & 0,00312 \\
\hline
\end{tabular}

Resultados de Análise de Cloreto, em mg/L.

\begin{tabular}{|c|c|c|c|c|}
\hline & ago/08 & out/08 & fev/09 & abr/09 \\
\hline PM 1 & 2,15300 & 1,90800 & 3,85300 & 2,57600 \\
\hline PM 2 & 2,11500 & 2,02600 & 2,14100 & 2,51300 \\
\hline PM 3 & 2,07400 & 2,06200 & 4,26200 & 2,47800 \\
\hline PM 4 & 2,05900 & 1,93500 & 2,39200 & 2,54700 \\
\hline PM 5 & 2,06100 & 2,00900 & 1,96800 & 2,34500 \\
\hline PM 6 & 2,13500 & 1,95000 & 2,04900 & 2,43100 \\
\hline PM 7 & 1,14730 & 1,98100 & 6,44300 & 2,39900 \\
\hline PM 8 & 1,98400 & 2,06100 & 2,84200 & 2,35700 \\
\hline PM 9 & 1,99000 & 1,98400 & 5,34600 & 2,12900 \\
\hline PM 10 & 2,25600 & 1,92500 & 3,89500 & 2,42100 \\
\hline PM 11 & 2,21500 & 1,98500 & 4,37700 & 3,41640 \\
\hline PM 12 & 1,89300 & 1,93000 & 2,97600 & 2,26900 \\
\hline PM 13 & 2,27700 & 1,99300 & 2,70500 & 2,51200 \\
\hline PM 14 & 2,36500 & 1,93600 & 1,98700 & 2,26300 \\
\hline PM 15 & 2,27300 & 1,99400 & 2,93100 & 2,78200 \\
\hline PM 16 & 2,78900 & 2,11400 & 2,06800 & 2,68300 \\
\hline PM 17 & 2,39000 & 1,96200 & 2,16200 & 2,58400 \\
\hline
\end{tabular}


Resultados de Análise de Nitrato, em mg/L.

\begin{tabular}{|c|c|c|c|c|}
\hline & ago/08 & out/08 & fev/09 & abr/09 \\
\hline PM 1 & 0,18548 & 0,84100 & 2,24900 & 1,49500 \\
\hline PM 2 & 1,94735 & 2,06300 & 2,39600 & 1,77600 \\
\hline PM 3 & 1,94488 & 2,06600 & 2,43100 & 1,81600 \\
\hline PM 4 & 1,91453 & 1,89900 & 2,40200 & 1,80600 \\
\hline PM 5 & 1,84832 & 1,91400 & 2,46700 & 1,80500 \\
\hline PM 6 & 1,94632 & 1,98900 & 2,50900 & 1,81000 \\
\hline PM 7 & 1,90046 & 1,98800 & 2,30700 & 1,79200 \\
\hline PM 8 & 1,86024 & 2,06700 & 2,43500 & 1,75400 \\
\hline PM 9 & 1,75928 & 1,86200 & 2,24400 & 1,66700 \\
\hline PM 10 & 1,97859 & 2,00300 & 2,55300 & 1,84800 \\
\hline PM 11 & 2,13143 & 2,28700 & 2,51100 & 1,90900 \\
\hline PM 12 & 2,11062 & 2,15900 & 2,43700 & 1,83800 \\
\hline PM 13 & 2,03647 & 1,95700 & 2,28500 & 1,77700 \\
\hline PM 14 & 2,13346 & 2,17900 & 2,42900 & 1,83100 \\
\hline PM 15 & 2,14152 & 2,19100 & 2,43700 & 1,88800 \\
\hline PM 16 & 2,20077 & 2,26700 & 2,46700 & 1,88500 \\
\hline PM 17 & 2,06868 & 2,11700 & 2,37900 & 1,87300 \\
\hline
\end{tabular}

Resultados de Análise de Nitrito, em mg/L.

\begin{tabular}{|c|c|c|c|c|}
\hline & ago/08 & out/08 & fev/09 & abr/09 \\
\hline PM 1 & 0,18548 & 0,02381 & 0,01416 & 0,00100 \\
\hline PM 2 & 1,94735 & 0,02736 & 0,01203 & 0,00104 \\
\hline PM 3 & 1,94488 & 0,05699 & 0,02374 & 0,00161 \\
\hline PM 4 & 1,91453 & 0,02309 & 0,01861 & 0,00126 \\
\hline PM 5 & 1,84832 & 0,02504 & 0,01025 & 0,00115 \\
\hline PM 6 & 1,94632 & 0,02204 & 0,01655 & 0,00128 \\
\hline PM 7 & 1,90046 & 0,02168 & 0,00294 & 0,00123 \\
\hline PM 8 & 1,86024 & 0,47213 & 0,01526 & 0,00101 \\
\hline PM 9 & 1,75928 & 0,02319 & 0,00399 & 0,00105 \\
\hline PM 10 & 1,97859 & 0,02225 & 0,01267 & 0,00126 \\
\hline PM 11 & 2,13143 & 0,02288 & 0,01503 & 0,00121 \\
\hline PM 12 & 2,11062 & 0,02180 & 0,00748 & 0,00109 \\
\hline PM 13 & 2,03647 & 0,02647 & 0,00675 & 0,00112 \\
\hline PM 14 & 2,13346 & 0,02681 & 0,00814 & 0,00092 \\
\hline PM 15 & 2,14152 & 0,02631 & 0,00921 & 0,00108 \\
\hline PM 16 & 2,20077 & 0,02432 & 0,00742 & 0,00149 \\
\hline PM 17 & 2,06868 & 0,02487 & 0,00751 & 0,00107 \\
\hline
\end{tabular}


Resultados de Análise de Amônio, em mg/L.

\begin{tabular}{|c|c|c|c|c|}
\hline & ago/08 & out/08 & fev/09 & abr/09 \\
\hline PM 1 & 0,17965 & 0,02358 & 0,02792 & 0,18934 \\
\hline PM 2 & 0,02138 & 0,04554 & 0,01941 & 0,16468 \\
\hline PM 3 & 0,10731 & 0,04348 & 0,02277 & 0,16967 \\
\hline PM 4 & 0,20251 & 0,03380 & 0,02668 & 0,17060 \\
\hline PM 5 & 0,21072 & 0,04957 & 0,02273 & 0,14033 \\
\hline PM 6 & 0,18749 & 0,04839 & 0,02756 & 0,17428 \\
\hline PM 7 & 0,14772 & 0,02254 & 0,01404 & 0,18584 \\
\hline PM 8 & 0,11952 & 0,03588 & 0,02107 & 0,12665 \\
\hline PM 9 & 0,12574 & 0,04607 & 0,02825 & 0,18853 \\
\hline PM 10 & 0,21512 & 0,03846 & 0,02591 & 0,14566 \\
\hline PM 11 & 0,12472 & 0,03669 & 0,03864 & 0,16093 \\
\hline PM 12 & 0,08247 & 0,04160 & 0,01988 & 0,15066 \\
\hline PM 13 & 0,18465 & 0,04043 & 0,01777 & 0,14067 \\
\hline PM 14 & 0,16789 & 0,00678 & 0,02377 & 0,13192 \\
\hline PM 15 & 0,13551 & 0,04802 & 0,04673 & 0,16390 \\
\hline PM 16 & 0,10507 & 0,05362 & 0,03454 & 0,18043 \\
\hline PM 17 & 0,08670 & 0,05336 & 0,04186 & 0,17909 \\
\hline
\end{tabular}

Resultados de Análise de Alumínio, em mg/L.

\begin{tabular}{|c|c|c|c|c|}
\hline & ago/08 & out/08 & fev/09 & abr/09 \\
\cline { 1 - 4 } PM 1 & 0,02007 & 0,00749 & 0,03461 & 0,00422 \\
\hline PM 2 & 0,01402 & 0,00114 & 0,03488 & 0,00560 \\
\hline PM 3 & 0,01115 & 0,00025 & 0,03469 & 0,01430 \\
\hline PM 4 & 0,01219 & 0,00027 & 0,03384 & 0,01395 \\
\hline PM 5 & 0,00767 & 0,07101 & 0,03508 & 0,00892 \\
\hline PM 6 & 0,00864 & 0,00255 & 0,03500 & 0,00690 \\
\hline PM 7 & 0,00542 & 0,00342 & 0,03526 & 0,03717 \\
\hline PM 8 & 0,00406 & 0,00316 & 0,03606 & 0,01538 \\
\hline PM 9 & 0,00500 & 0,02139 & 0,03631 & 0,01272 \\
\hline PM 10 & 0,00486 & 0,00109 & 0,03568 & 0,02137 \\
\hline PM 11 & 0,00772 & 0,04240 & 0,03651 & 0,00917 \\
\hline PM 12 & 0,00902 & 0,01731 & 0,03669 & 0,01063 \\
\hline PM 13 & 0,01367 & 0,02722 & 0,03698 & 0,01065 \\
\hline PM 14 & 0,01459 & 0,02380 & 0,03540 & 0,01871 \\
\hline PM 15 & 0,00888 & 0,00656 & 0,03712 & 0,01145 \\
\hline PM 16 & 0,00897 & 0,00236 & 0,03750 & 0,00155 \\
\hline PM 17 & 0,00694 & 0,00498 & 0,03778 & 0,00488 \\
\hline
\end{tabular}


Resultados de Análise de Boro, em mg/L.

\begin{tabular}{|c|c|c|c|c|}
\hline & ago/08 & out/08 & fev/09 & abr/09 \\
\hline PM 1 & 0,083788 & 0,00320 & 0,011785 & 0,00185 \\
\hline PM 2 & 0,073898 & 0,00290 & 0,012498 & 0,00198 \\
\hline PM 3 & 0,071079 & 0,00363 & 0,011917 & 0,00330 \\
\hline PM 4 & 0,066153 & 0,00283 & 0,013511 & 0,00283 \\
\hline PM 5 & 0,064608 & 0,00285 & 0,012788 & 0,00241 \\
\hline PM 6 & 0,063271 & 0,00276 & 0,014404 & 0,00291 \\
\hline PM 7 & 0,061699 & 0,00274 & 0,013861 & 0,00321 \\
\hline PM 8 & 0,060706 & 0,00267 & 0,014064 & 0,00243 \\
\hline PM 9 & 0,060375 & 0,00170 & 0,014835 & 0,00180 \\
\hline PM 10 & 0,060540 & 0,00288 & 0,013737 & 0,00055 \\
\hline PM 11 & 0,059470 & 0,00264 & 0,014824 & 0,00190 \\
\hline PM 12 & 0,058881 & 0,00243 & 0,012981 & 0,00326 \\
\hline PM 13 & 0,061587 & 0,00180 & 0,014851 & 0,00192 \\
\hline PM 14 & 0,058556 & 0,00262 & 0,014457 & 0,00302 \\
\hline PM 15 & 0,061024 & 0,00281 & 0,013217 & 0,00273 \\
\hline PM 16 & 0,057955 & 0,00303 & 0,015043 & 0,00128 \\
\hline PM 17 & 0,056373 & 0,00293 & 0,014454 & 0,00159 \\
\hline
\end{tabular}

Resultados de Análise de Cálcio, em mg/L.

\begin{tabular}{|c|c|c|c|c|}
\hline & ago/08 & out/08 & fev/09 & abr/09 \\
\hline PM 1 & 0,95454 & 0,96664 & 0,59501 & 0,79141 \\
\hline PM 2 & 0,85885 & 0,87010 & 0,52262 & 0,78087 \\
\hline PM 3 & 0,84690 & 0,88637 & 0,61812 & 0,74431 \\
\hline PM 4 & 0,81796 & 0,81907 & 0,64009 & 0,69543 \\
\hline PM 5 & 0,80964 & 0,76005 & 0,73825 & 0,74601 \\
\hline PM 6 & 0,79263 & 0,79701 & 0,57390 & 0,70447 \\
\hline PM 7 & 0,79063 & 0,84785 & 0,65301 & 0,74229 \\
\hline PM 8 & 0,94439 & 0,82380 & 0,79748 & 0,76899 \\
\hline PM 9 & 0,84173 & 0,85573 & 0,81254 & 0,97005 \\
\hline PM 10 & 0,77126 & 0,85765 & 0,55390 & 0,74091 \\
\hline PM 11 & 0,79689 & 0,89204 & 0,58048 & 0,71726 \\
\hline PM 12 & 0,81410 & 0,89565 & 0,57067 & 0,71508 \\
\hline PM 13 & 0,93185 & 0,87595 & 0,56995 & 0,67668 \\
\hline PM 14 & 1,02945 & 0,81193 & 0,55970 & 0,70524 \\
\hline PM 15 & 1,06304 & 0,82469 & 0,57973 & 0,70350 \\
\hline PM 16 & 0,97135 & 0,89370 & 0,54010 & 0,68003 \\
\hline PM 17 & 0,85109 & 1,00963 & 0,58049 & 0,68550 \\
\hline
\end{tabular}


Resultados de Análise de Cádmio, em mg/L.

\begin{tabular}{|c|c|c|c|c|}
\hline & ago/08 & out/08 & fev/09 & abr/09 \\
\hline PM 1 & 0,00526 & 0,00103 & 0,00013 & 0,00050 \\
\hline PM 2 & 0,00519 & 0,00123 & 0,00004 & 0,00032 \\
\hline PM 3 & 0,00504 & 0,00115 & 0,00003 & 0,00029 \\
\hline PM 4 & 0,00510 & 0,00115 & 0,00002 & 0,00036 \\
\hline PM 5 & 0,00497 & 0,00105 & 0,00012 & 0,00027 \\
\hline PM 6 & 0,00497 & 0,00109 & 0,00012 & 0,00040 \\
\hline PM 7 & 0,00501 & 0,00106 & 0,00002 & 0,00050 \\
\hline PM 8 & 0,00510 & 0,00107 & 0,00032 & 0,00015 \\
\hline PM 9 & 0,00514 & 0,00118 & 0,00003 & 0,00027 \\
\hline PM 10 & 0,00508 & 0,00106 & 0,00001 & 0,00006 \\
\hline PM 11 & 0,00481 & 0,00111 & 0,00017 & 0,00033 \\
\hline PM 12 & 0,00510 & 0,00106 & 0,00011 & 0,00043 \\
\hline PM 13 & 0,00495 & 0,00112 & 0,00047 & 0,00025 \\
\hline PM 14 & 0,00497 & 0,00122 & 0,00032 & 0,00040 \\
\hline PM 15 & 0,00462 & 0,00105 & 0,00020 & 0,00038 \\
\hline PM 16 & 0,00507 & 0,00115 & 0,00030 & 0,00076 \\
\hline PM 17 & 0,00514 & 0,00123 & 0,00025 & 0,00021 \\
\hline
\end{tabular}

Resultados de Análise de Cromo, em mg/L.

\begin{tabular}{|c|c|c|c|c|}
\hline & ago/08 & out/08 & fev/09 & abr/09 \\
\hline PM 1 & 0,00568 & 0,00252 & 0,00115 & 0,00146 \\
\hline PM 2 & 0,00660 & 0,00249 & 0,00235 & 0,00149 \\
\hline PM 3 & 0,00517 & 0,00246 & 0,00179 & 0,00134 \\
\hline PM 4 & 0,00563 & 0,00243 & 0,00212 & 0,00149 \\
\hline PM 5 & 0,00659 & 0,00266 & 0,00196 & 0,00185 \\
\hline PM 6 & 0,00612 & 0,00302 & 0,00148 & 0,00187 \\
\hline PM 7 & 0,00628 & 0,00250 & 0,00147 & 0,00188 \\
\hline PM 8 & 0,00585 & 0,00282 & 0,00131 & 0,00177 \\
\hline PM 9 & 0,00567 & 0,00273 & 0,00191 & 0,00115 \\
\hline PM 10 & 0,00610 & 0,00253 & 0,00248 & 0,00181 \\
\hline PM 11 & 0,00613 & 0,00272 & 0,00278 & 0,00117 \\
\hline PM 12 & 0,00579 & 0,00309 & 0,00142 & 0,00120 \\
\hline PM 13 & 0,00599 & 0,00270 & 0,00250 & 0,00166 \\
\hline PM 14 & 0,00608 & 0,00281 & 0,00201 & 0,00198 \\
\hline PM 15 & 0,00573 & 0,00284 & 0,00211 & 0,00329 \\
\hline PM 16 & 0,00575 & 0,00256 & 0,00219 & 0,00133 \\
\hline PM 17 & 0,00529 & 0,00249 & 0,00264 & 0,00168 \\
\hline
\end{tabular}


Resultados de Análise de Cobre, em mg/L.

\begin{tabular}{|c|c|c|c|c|}
\hline & ago/08 & out/08 & fev/09 & abr/09 \\
\hline PM 1 & 0,01167 & 0,01151 & 0,00353 & 0,00256 \\
\hline PM 2 & 0,01029 & 0,01104 & 0,00268 & 0,00148 \\
\hline PM 3 & 0,01086 & 0,01206 & 0,00277 & 0,00107 \\
\hline PM 4 & 0,01036 & 0,01187 & 0,00349 & 0,00160 \\
\hline PM 5 & 0,01063 & 0,01200 & 0,00272 & 0,00183 \\
\hline PM 6 & 0,01040 & 0,01114 & 0,00393 & 0,00188 \\
\hline PM 7 & 0,01023 & 0,01202 & 0,00249 & 0,00155 \\
\hline PM 8 & 0,01059 & 0,01149 & 0,00351 & 0,00091 \\
\hline PM 9 & 0,01025 & 0,01206 & 0,00192 & 0,00113 \\
\hline PM 10 & 0,01034 & 0,01174 & 0,00365 & 0,00126 \\
\hline PM 11 & 0,01004 & 0,01187 & 0,00314 & 0,00184 \\
\hline PM 12 & 0,01018 & 0,01158 & 0,00200 & 0,00166 \\
\hline PM 13 & 0,01114 & 0,01124 & 0,00406 & 0,00148 \\
\hline PM 14 & 0,01044 & 0,01104 & 0,00249 & 0,00267 \\
\hline PM 15 & 0,01015 & 0,01158 & 0,00345 & 0,00067 \\
\hline PM 16 & 0,01029 & 0,01250 & 0,00353 & 0,00055 \\
\hline PM 17 & 0,01034 & 0,01079 & 0,00272 & 0,00227 \\
\hline
\end{tabular}

Resultados de Análise de Ferro, em mg/L.

\begin{tabular}{|c|c|c|c|c|}
\hline & ago/08 & out/08 & fev/09 & abr/09 \\
\hline PM 1 & 0,04495 & 0,02880 & 0,01213 & 0,02079 \\
\hline PM 2 & 0,03016 & 0,02408 & 0,01189 & 0,01822 \\
\hline PM 3 & 0,02872 & 0,02313 & 0,01191 & 0,01757 \\
\hline PM 4 & 0,02995 & 0,02276 & 0,01166 & 0,01756 \\
\hline PM 5 & 0,02707 & 0,07261 & 0,01209 & 0,01772 \\
\hline PM 6 & 0,02714 & 0,02496 & 0,01186 & 0,01779 \\
\hline PM 7 & 0,02609 & 0,02500 & 0,01214 & 0,01734 \\
\hline PM 8 & 0,02535 & 0,02511 & 0,01319 & 0,01726 \\
\hline PM 9 & 0,02546 & 0,03473 & 0,01287 & 0,01782 \\
\hline PM 10 & 0,02587 & 0,02284 & 0,01187 & 0,01750 \\
\hline PM 11 & 0,02714 & 0,04887 & 0,01269 & 0,01821 \\
\hline PM 12 & 0,02740 & 0,03201 & 0,01220 & 0,01771 \\
\hline PM 13 & 0,03013 & 0,03789 & 0,01279 & 0,01781 \\
\hline PM 14 & 0,03084 & 0,04114 & 0,01135 & 0,01817 \\
\hline PM 15 & 0,02743 & 0,02842 & 0,01204 & 0,01795 \\
\hline PM 16 & 0,02900 & 0,02367 & 0,01318 & 0,01739 \\
\hline PM 17 & 0,02635 & 0,02685 & 0,01302 & 0,01750 \\
\hline
\end{tabular}


Resultados de Análise de Potássio, em mg/L.

\begin{tabular}{|c|c|c|c|c|}
\hline & ago/08 & out/08 & fev/09 & abr/09 \\
\hline PM 1 & 0,19470 & 0,17809 & 0,15701 & 0,19622 \\
\hline PM 2 & 0,13654 & 0,12130 & 0,11056 & 0,15801 \\
\hline PM 3 & 0,11632 & 0,12596 & 0,17140 & 0,16446 \\
\hline PM 4 & 0,11124 & 0,11076 & 0,09017 & 0,13536 \\
\hline PM 5 & 0,10675 & 0,10370 & 0,13768 & 0,15429 \\
\hline PM 6 & 0,10269 & 0,11034 & 0,07159 & 0,17237 \\
\hline PM 7 & 0,21776 & 0,12222 & 0,13689 & 0,14679 \\
\hline PM 8 & 0,10385 & 0,13059 & 0,09638 & 0,15864 \\
\hline PM 9 & 0,09280 & 0,11299 & 0,10689 & 0,14657 \\
\hline PM 10 & 0,10429 & 0,10573 & 0,09474 & 0,26317 \\
\hline PM 11 & 0,21140 & 0,11676 & 0,09797 & 0,14337 \\
\hline PM 12 & 0,09141 & 0,10759 & 0,07246 & 0,13734 \\
\hline PM 13 & 0,10842 & 0,09485 & 0,18153 & 0,14533 \\
\hline PM 14 & 0,14439 & 0,09969 & 0,07976 & 0,17958 \\
\hline PM 15 & 0,11901 & 0,09738 & 0,07927 & 0,23673 \\
\hline PM 16 & 0,11969 & 0,10543 & 0,08005 & 0,18144 \\
\hline PM 17 & 0,10348 & 0,10546 & 0,09982 & 0,21103 \\
\hline
\end{tabular}

Resultados de Análise de Magnésio, em mg/L.

\begin{tabular}{|c|c|c|c|c|}
\hline & ago/08 & out/08 & fev/09 & abr/09 \\
\hline PM 1 & 0,58007 & 0,55890 & 0,43730 & 0,47818 \\
\hline PM 2 & 0,50976 & 0,46120 & 0,38403 & 0,44199 \\
\hline PM 3 & 0,48231 & 0,47668 & 0,40316 & 0,42237 \\
\hline PM 4 & 0,47970 & 0,46314 & 0,40383 & 0,44296 \\
\hline Pm 5 & 0,46909 & 0,44235 & 0,43229 & 0,44256 \\
\hline PM 6 & 0,45781 & 0,45928 & 0,38872 & 0,39818 \\
\hline PM 7 & 0,45632 & 0,44779 & 0,41274 & 0,42189 \\
\hline PM 8 & 0,48384 & 0,45024 & 0,45487 & 0,47821 \\
\hline PM 9 & 0,44961 & 0,43157 & 0,45606 & 0,44150 \\
\hline PM 10 & 0,45491 & 0,43477 & 0,37915 & 0,44316 \\
\hline PM 11 & 0,46879 & 0,43424 & 0,39300 & 0,43609 \\
\hline PM 12 & 0,47598 & 0,47102 & 0,37481 & 0,42085 \\
\hline PM 13 & 0,48440 & 0,46422 & 0,40793 & 0,44543 \\
\hline PM 14 & 0,49685 & 0,44674 & 0,38907 & 0,48236 \\
\hline PM 15 & 0,49038 & 0,44936 & 0,34790 & 0,44033 \\
\hline PM 16 & 0,48523 & 0,44953 & 0,34356 & 0,43393 \\
\hline PM 17 & 0,44551 & 0,46929 & 0,34233 & 0,41617 \\
\hline
\end{tabular}


Resultados de Análise de Manganês, em mg/L.

\begin{tabular}{|c|c|c|c|c|}
\hline & ago/08 & out/08 & fev/09 & abr/09 \\
\hline PM 1 & 0,04053 & 0,01758 & 0,00471 & 0,00312 \\
\hline PM 2 & 0,01055 & 0,00609 & 0,00332 & 0,00226 \\
\hline PM 3 & 0,00857 & 0,00680 & 0,00302 & 0,00162 \\
\hline PM 4 & 0,00763 & 0,00777 & 0,00305 & 0,00171 \\
\hline PM 5 & 0,00924 & 0,00430 & 0,00411 & 0,00243 \\
\hline PM 6 & 0,00675 & 0,00444 & 0,00322 & 0,00118 \\
\hline PM 7 & 0,00919 & 0,00676 & 0,00345 & 0,00199 \\
\hline PM 8 & 0,01333 & 0,02383 & 0,00481 & 0,00324 \\
\hline PM 9 & 0,01246 & 0,04333 & 0,00429 & 0,00576 \\
\hline PM 10 & 0,00712 & 0,00908 & 0,00255 & 0,00157 \\
\hline PM 11 & 0,00673 & 0,00579 & 0,00513 & 0,00158 \\
\hline PM 12 & 0,00673 & 0,00458 & 0,00340 & 0,00141 \\
\hline PM 13 & 0,00785 & 0,00538 & 0,00265 & 0,00175 \\
\hline PM 14 & 0,00825 & 0,00405 & 0,00283 & 0,00204 \\
\hline PM 15 & 0,00681 & 0,00585 & 0,00284 & 0,00110 \\
\hline PM 16 & 0,00898 & 0,00542 & 0,00283 & 0,00156 \\
\hline PM 17 & 0,00651 & 0,01581 & 0,00296 & 0,00255 \\
\hline
\end{tabular}

Resultados de Análise de Sódio, em mg/L.

\begin{tabular}{|c|c|c|c|c|}
\hline & ago/08 & out/08 & fev/09 & abr/09 \\
\hline PM 1 & 1,21959 & 1,07375 & 1,26356 & 1,20351 \\
\hline PM 2 & 1,27847 & 1,15970 & 1,28953 & 1,33272 \\
\hline PM 3 & 1,31844 & 1,15430 & 1,32735 & 1,32267 \\
\hline PM 4 & 1,28963 & 1,15136 & 1,35882 & 1,33487 \\
\hline PM 5 & 1,27596 & 1,14430 & 1,47853 & 1,37132 \\
\hline PM 6 & 1,30214 & 1,11395 & 1,40090 & 1,27128 \\
\hline PM 7 & 1,34555 & 1,16584 & 1,43226 & 1,53170 \\
\hline PM 8 & 1,33043 & 1,13366 & 1,43724 & 1,53634 \\
\hline PM 9 & 1,24717 & 1,10869 & 1,35963 & 1,46735 \\
\hline PM 10 & 1,29555 & 1,14191 & 1,44173 & 1,55973 \\
\hline PM 11 & 1,30220 & 1,17075 & 1,42651 & 1,56054 \\
\hline PM 12 & 1,30104 & 1,16763 & 1,32404 & 1,50378 \\
\hline PM 13 & 1,34108 & 1,14769 & 1,46407 & 1,53168 \\
\hline PM 14 & 1,34145 & 1,09422 & 1,44113 & 1,52987 \\
\hline PM 15 & 1,38339 & 1,12113 & 1,38029 & 1,59692 \\
\hline PM 16 & 1,41477 & 1,19869 & 1,36689 & 1,60525 \\
\hline PM 17 & 1,36564 & 1,14685 & 1,37414 & 1,56105 \\
\hline
\end{tabular}


Resultados de Análise de Níquel, em mg/L.

\begin{tabular}{|c|c|c|c|c|}
\hline & ago/08 & out/08 & fev/09 & abr/09 \\
\hline PM 1 & 0,00471 & 0,00052 & 0,00029 & 0,14602 \\
\hline PM 2 & 0,00373 & 0,00029 & 0,00082 & 0,14640 \\
\hline PM 3 & 0,00420 & 0,00020 & 0,00000 & 0,11658 \\
\hline PM 4 & 0,00504 & 0,00125 & 0,00005 & 0,13009 \\
\hline PM 5 & 0,00373 & 0,00071 & 0,00081 & 0,12123 \\
\hline PM 6 & 0,00507 & 0,00051 & 0,00057 & 0,14352 \\
\hline PM 7 & 0,00316 & 0,00024 & 0,00104 & 0,13977 \\
\hline PM 8 & 0,00418 & 0,00058 & 0,00021 & 0,14013 \\
\hline PM 9 & 0,00531 & 0,00039 & 0,00012 & 0,14538 \\
\hline PM 10 & 0,00461 & 0,00050 & 0,00051 & 0,14404 \\
\hline PM 11 & 0,00450 & 0,00040 & 0,00089 & 0,13920 \\
\hline PM 12 & 0,00533 & 0,00033 & 0,00024 & 0,12573 \\
\hline PM 13 & 0,00447 & 0,00013 & 0,00101 & 0,13221 \\
\hline PM 14 & 0,00349 & 0,00015 & 0,00038 & 0,13843 \\
\hline PM 15 & 0,00450 & 0,00023 & 0,00026 & 0,13481 \\
\hline PM 16 & 0,00549 & 0,00026 & 0,00085 & 0,12214 \\
\hline PM 17 & 0,00406 & 0,00041 & 0,00062 & 0,11593 \\
\hline
\end{tabular}

Resultados de Análise de Fósforo, em mg/L.

\begin{tabular}{|c|c|c|c|c|}
\hline & ago/08 & out/08 & fev/09 & abr/09 \\
\hline PM 1 & 0,01328 & 0,03759 & 0,08081 & 0,00437 \\
\hline PM 2 & 0,01279 & 0,01704 & 0,06340 & 0,00596 \\
\hline PM 3 & 0,01229 & 0,10508 & 0,06303 & 0,00931 \\
\hline PM 4 & 0,01120 & 0,02107 & 0,07878 & 0,01458 \\
\hline PM 5 & 0,01242 & 0,09534 & 0,09487 & 0,01010 \\
\hline PM 6 & 0,00612 & 0,02468 & 0,04107 & 0,02477 \\
\hline PM 7 & 0,00940 & 0,03059 & 0,05935 & 0,01100 \\
\hline PM 8 & 0,00685 & 0,11819 & 0,10720 & 0,00541 \\
\hline PM 9 & 0,00923 & 0,00121 & 0,04591 & 0,01116 \\
\hline PM 10 & 0,00925 & 0,10316 & 0,03282 & 0,00422 \\
\hline PM 11 & 0,01039 & 0,01538 & 0,03170 & 0,00322 \\
\hline PM 12 & 0,00780 & 0,00801 & 0,07520 & 0,00969 \\
\hline PM 13 & 0,00761 & 0,08236 & 0,07613 & 0,00859 \\
\hline PM 14 & 0,01149 & 0,01940 & 0,09274 & 0,00096 \\
\hline PM 15 & 0,00892 & 0,00687 & 0,08003 & 0,00373 \\
\hline PM 16 & 0,00603 & 0,02103 & 0,02770 & 0,01120 \\
\hline PM 17 & 0,00608 & 0,03040 & 0,05832 & 0,00145 \\
\hline
\end{tabular}


Resultados de Análise de Enxofre, em mg/L.

\begin{tabular}{|c|c|c|c|c|}
\hline & ago/08 & out/08 & fev/09 & abr/09 \\
\hline PM 1 & 0,15910 & 0,07537 & 0,20696 & 0,36259 \\
\hline PM 2 & 0,12495 & 0,05981 & 0,23781 & 0,24851 \\
\hline PM 3 & 0,10580 & 0,07481 & 0,34766 & 0,39227 \\
\hline PM 4 & 0,12609 & 0,06697 & 0,27042 & 0,28261 \\
\hline PM 5 & 0,10524 & 0,06834 & 0,32473 & 0,44247 \\
\hline PM 6 & 0,10526 & 0,04961 & 0,27607 & 0,40919 \\
\hline PM 7 & 0,11634 & 0,06258 & 0,24232 & 0,26878 \\
\hline PM 8 & 0,12249 & 0,05769 & 0,20569 & 0,57820 \\
\hline PM 9 & 0,13119 & 0,05297 & 0,25587 & 0,79297 \\
\hline PM 10 & 0,10522 & 0,05463 & 0,27193 & 0,80480 \\
\hline PM 11 & 0,12215 & 0,05823 & 0,23820 & 0,42132 \\
\hline PM 12 & 0,08828 & 0,06167 & 0,17413 & 0,33058 \\
\hline PM 13 & 0,29446 & 0,08524 & 0,18447 & 0,84761 \\
\hline PM 14 & 0,38941 & 0,06157 & 0,12970 & 0,43362 \\
\hline PM 15 & 0,28949 & 0,07822 & 0,22466 & 0,52583 \\
\hline PM 16 & 0,40761 & 0,11773 & 0,19929 & 0,50034 \\
\hline PM 17 & 0,45063 & 0,09611 & 0,14397 & 0,44795 \\
\hline
\end{tabular}

Resultados de Análise de Zinco, em mg/L.

\begin{tabular}{|c|c|c|c|c|}
\hline & ago/08 & out/08 & fev/09 & abr/09 \\
\hline PM 1 & 0,00910 & 0,00554 & 0,00097 & 0,00904 \\
\hline PM 2 & 0,01124 & 0,00585 & 0,00117 & 0,03202 \\
\hline PM 3 & 0,01063 & 0,00678 & 0,00202 & 0,00856 \\
\hline PM 4 & 0,00827 & 0,00676 & 0,00245 & 0,01391 \\
\hline PM 5 & 0,01115 & 0,01444 & 0,00343 & 0,01603 \\
\hline PM 6 & 0,00855 & 0,00558 & 0,00209 & 0,02213 \\
\hline PM 7 & 0,01055 & 0,01485 & 0,00278 & 0,01492 \\
\hline PM 8 & 0,00823 & 0,00834 & 0,00332 & 0,01942 \\
\hline PM 9 & 0,01062 & 0,00719 & 0,00346 & 0,02236 \\
\hline PM 10 & 0,00998 & 0,01045 & 0,00286 & 0,02726 \\
\hline PM 11 & 0,00778 & 0,00605 & 0,00291 & 0,02976 \\
\hline PM 12 & 0,00853 & 0,00587 & 0,00261 & 0,02844 \\
\hline PM 13 & 0,01188 & 0,00513 & 0,00740 & 0,02160 \\
\hline PM 14 & 0,01451 & 0,00893 & 0,01142 & 0,01681 \\
\hline PM 15 & 0,01151 & 0,00549 & 0,01330 & 0,01721 \\
\hline PM 16 & 0,01089 & 0,00626 & 0,01666 & 0,02032 \\
\hline PM 17 & 0,01092 & 0,00604 & 0,01749 & 0,02123 \\
\hline
\end{tabular}


Resultados de Análise de Chumbo, em mg/L.

\begin{tabular}{|c|c|c|c|c|}
\hline & ago/08 & out/08 & fev/09 & abr/09 \\
\hline PM 1 & 0,156080 & 0,00140 & ND & 0,00454 \\
\hline PM 2 & 0,726308 & 0,00139 & ND & 0,00569 \\
\hline PM 3 & 0,172549 & 0,00068 & ND & 0,00230 \\
\hline PM 4 & 0,720524 & 0,00213 & ND & 0,00196 \\
\hline PM 5 & 0,348588 & 0,00097 & ND & 0,01420 \\
\hline PM 6 & 0,395615 & 0,00304 & ND & 0,00233 \\
\hline PM 7 & 0,649083 & 0,00130 & ND & 0,00164 \\
\hline PM 8 & 0,170291 & 0,00162 & ND & 0,00417 \\
\hline PM 9 & 0,534589 & 0,00283 & ND & 0,00397 \\
\hline PM 10 & 0,630283 & 0,00015 & ND & 0,00178 \\
\hline PM 11 & 0,195399 & 0,00073 & ND & 0,00277 \\
\hline PM 12 & 0,370807 & 0,00186 & ND & 0,00377 \\
\hline PM 13 & 0,844363 & 0,00180 & ND & 0,00331 \\
\hline PM 14 & 0,713319 & 0,00178 & ND & 0,00377 \\
\hline PM 15 & 0,337894 & 0,00154 & ND & 0,00470 \\
\hline PM 16 & 0,347768 & 0,00082 & ND & 0,00398 \\
\hline PM 17 & 0,354327 & 0,00217 & ND & 0,00787 \\
\hline
\end{tabular}

Resultados de Análise de DOC, em mg/L.

\begin{tabular}{|c|c|c|c|c|}
\hline & ago/08 & out/08 & fev/09 & abr/09 \\
\hline PM 1 & 0,86230 & 0,49730 & 0,86200 & 0,90500 \\
\hline PM 2 & 0,25850 & 0,36300 & 0,73220 & 0,84400 \\
\hline PM 3 & 0,23230 & 0,26890 & 0,70530 & 0,62300 \\
\hline PM 4 & 0,24070 & 0,30180 & 0,52390 & 0,80200 \\
\hline PM 5 & 0,19980 & 0,41750 & 0,87450 & 0,67700 \\
\hline PM 6 & 0,19110 & 0,37930 & 0,66140 & 0,61900 \\
\hline PM 7 & 0,40190 & 1,18200 & 1,40800 & 0,92900 \\
\hline PM 8 & 0,47590 & 0,46770 & 0,72180 & 0,76000 \\
\hline PM 9 & 0,50560 & 0,42510 & 0,55210 & 0,59100 \\
\hline PM 10 & 0,14620 & 0,51110 & 0,59500 & 0,77300 \\
\hline PM 11 & 0,51260 & 0,36610 & 0,92080 & 0,93300 \\
\hline PM 12 & 0,16980 & 0,562700 & 0,46390 & 0,87500 \\
\hline PM 13 & 0,20840 & 0,40420 & 0,49160 & 0,63100 \\
\hline PM 14 & 0,21410 & 0,39540 & 0,80380 & 0,68800 \\
\hline PM 15 & 0,25090 & 0,35150 & 0,49030 & 0,58900 \\
\hline PM 16 & 0,15770 & 0,33640 & 0,43530 & 0,48200 \\
\hline PM 17 & 0,38100 & 0,49710 & 0,59450 & 0,56400 \\
\hline
\end{tabular}


Resultados de Análise de pH.

\begin{tabular}{|c|c|c|c|c|}
\hline & ago/08 & out/08 & fev/09 & abr/09 \\
\hline PM 1 & 5,34 & 5,51 & 5,47 & 5,63 \\
\hline PM 2 & 5,52 & 5,33 & 5,50 & 5,72 \\
\hline PM 3 & 5,33 & 5,16 & 5,55 & 5,58 \\
\hline PM 4 & 5,27 & 5,37 & 5,54 & 5,66 \\
\hline PM 5 & 5,35 & 5,28 & 5,55 & 5,62 \\
\hline PM 6 & 5,32 & 5,08 & 5,51 & 5,47 \\
\hline PM 7 & 5,37 & 5,27 & 5,58 & 5,60 \\
\hline PM 8 & 5,33 & 5,22 & 5,59 & 5,48 \\
\hline PM 9 & 5,18 & 5,39 & 5,56 & 5,37 \\
\hline PM 10 & 5,32 & 5,23 & 5,61 & 5,46 \\
\hline PM 11 & 5,09 & 5,23 & 5,55 & 5,51 \\
\hline PM 12 & 5,28 & 5,44 & 5,59 & 5,27 \\
\hline PM 13 & 5,26 & 5,19 & 5,58 & 5,53 \\
\hline PM 14 & 5,26 & 5,27 & 5,53 & 5,61 \\
\hline PM 15 & 5,38 & 5,40 & 5,59 & 5,59 \\
\hline PM 16 & 5,21 & 5,43 & 5,58 & 5,56 \\
\hline PM 17 & 5,47 & 5,56 & 5,58 & 5,43 \\
\hline
\end{tabular}

Resultados de Análise de Condutividade Elétrica, em microSiemens/cm.

\begin{tabular}{|c|c|c|c|c|}
\hline & ago/08 & out/08 & fev/09 & abr/09 \\
\hline PM 1 & 26,97 & 27,31 & 23,66 & 23,65 \\
\hline PM 2 & 27,56 & 28,38 & 22,56 & 23,26 \\
\hline PM 3 & 26,91 & 27,55 & 23,06 & 23,39 \\
\hline PM 4 & 27,06 & 25,79 & 22,72 & 23,30 \\
\hline PM 5 & 26,86 & 26,35 & 24,26 & 23,54 \\
\hline PM 6 & 26,78 & 26,85 & 23,55 & 23,39 \\
\hline PM 7 & 28,80 & 27,06 & 23,31 & 23,60 \\
\hline PM 8 & 27,49 & 26,53 & 25,19 & 23,40 \\
\hline PM 9 & 26,28 & 26,77 & 24,18 & 22,73 \\
\hline PM 10 & 26,70 & 26,51 & 22,06 & 22,76 \\
\hline PM 11 & 26,53 & 27,13 & 22,80 & 23,15 \\
\hline PM 12 & 26,74 & 26,71 & 22,59 & 22,96 \\
\hline PM 13 & 26,63 & 27,38 & 22,50 & 23,04 \\
\hline PM 14 & 26,49 & 27,31 & 22,40 & 23,05 \\
\hline PM 15 & 26,78 & 27,18 & 22,19 & 22,79 \\
\hline PM 16 & 26,94 & 27,36 & 22,17 & 23,00 \\
\hline PM 17 & 25,96 & 27,95 & 21,82 & 22,58 \\
\hline
\end{tabular}


ANEXO II

MAPAS DE LEVANTAMENTO

ELETROMAGNÉTICO 

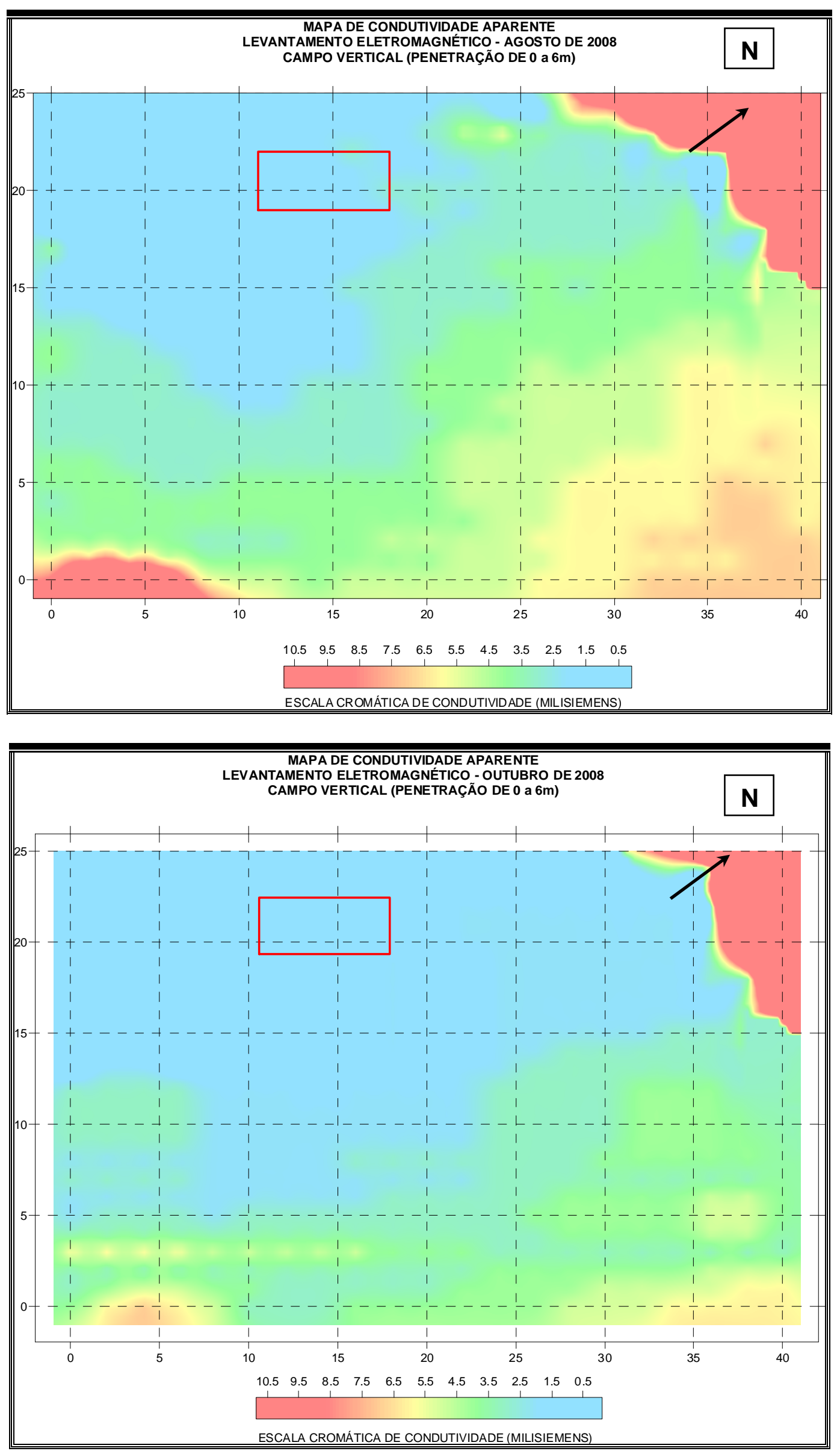

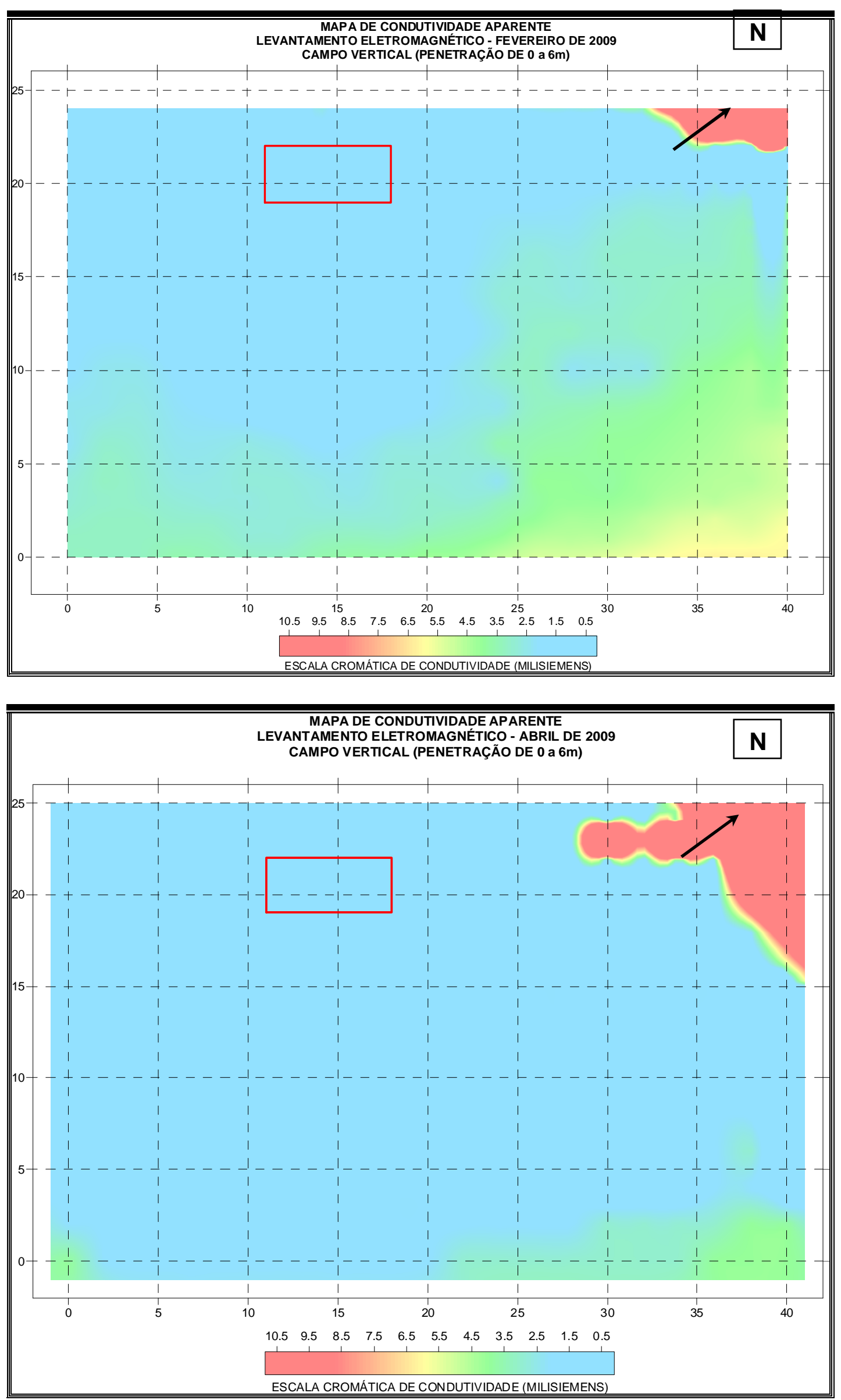

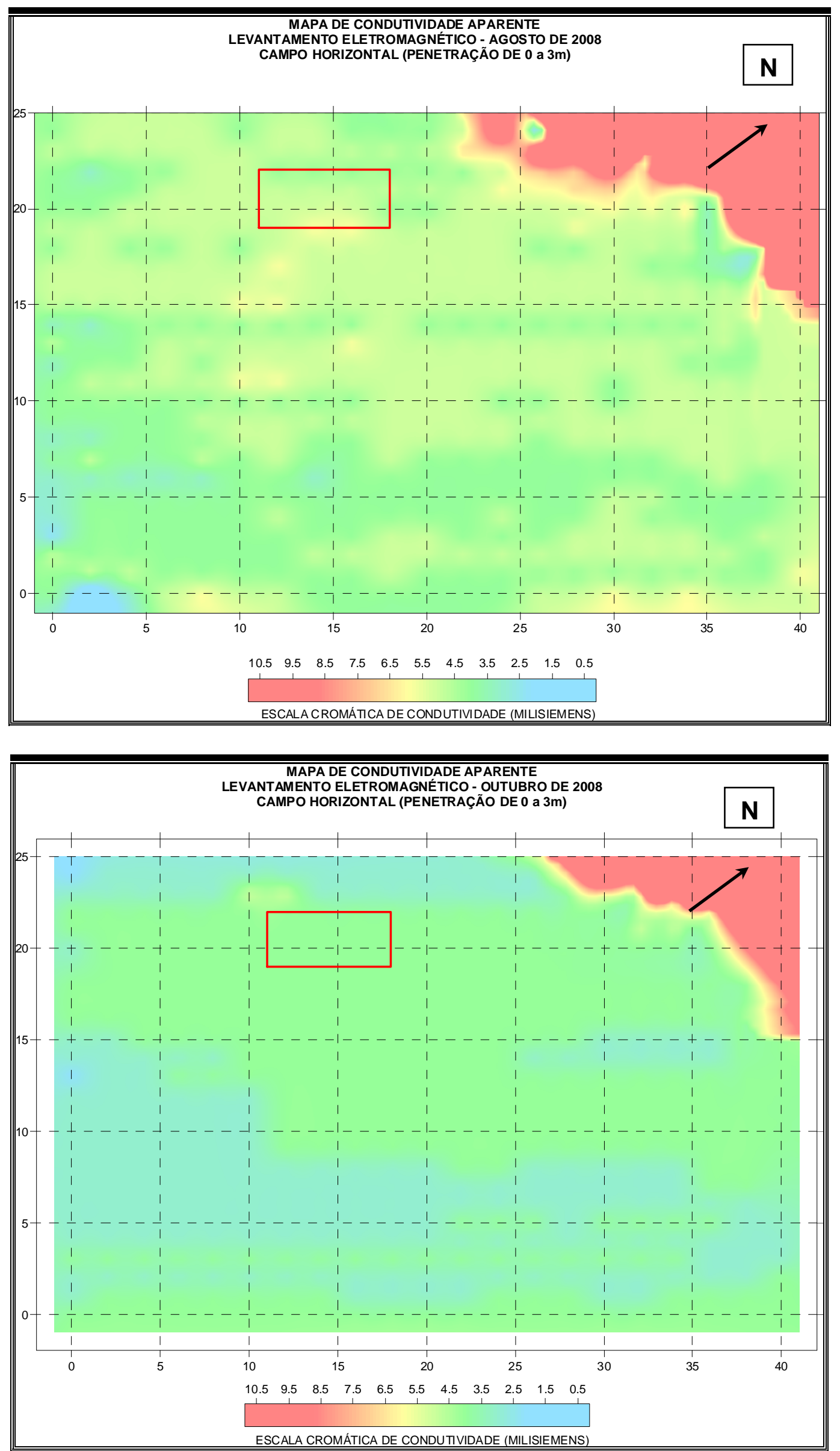

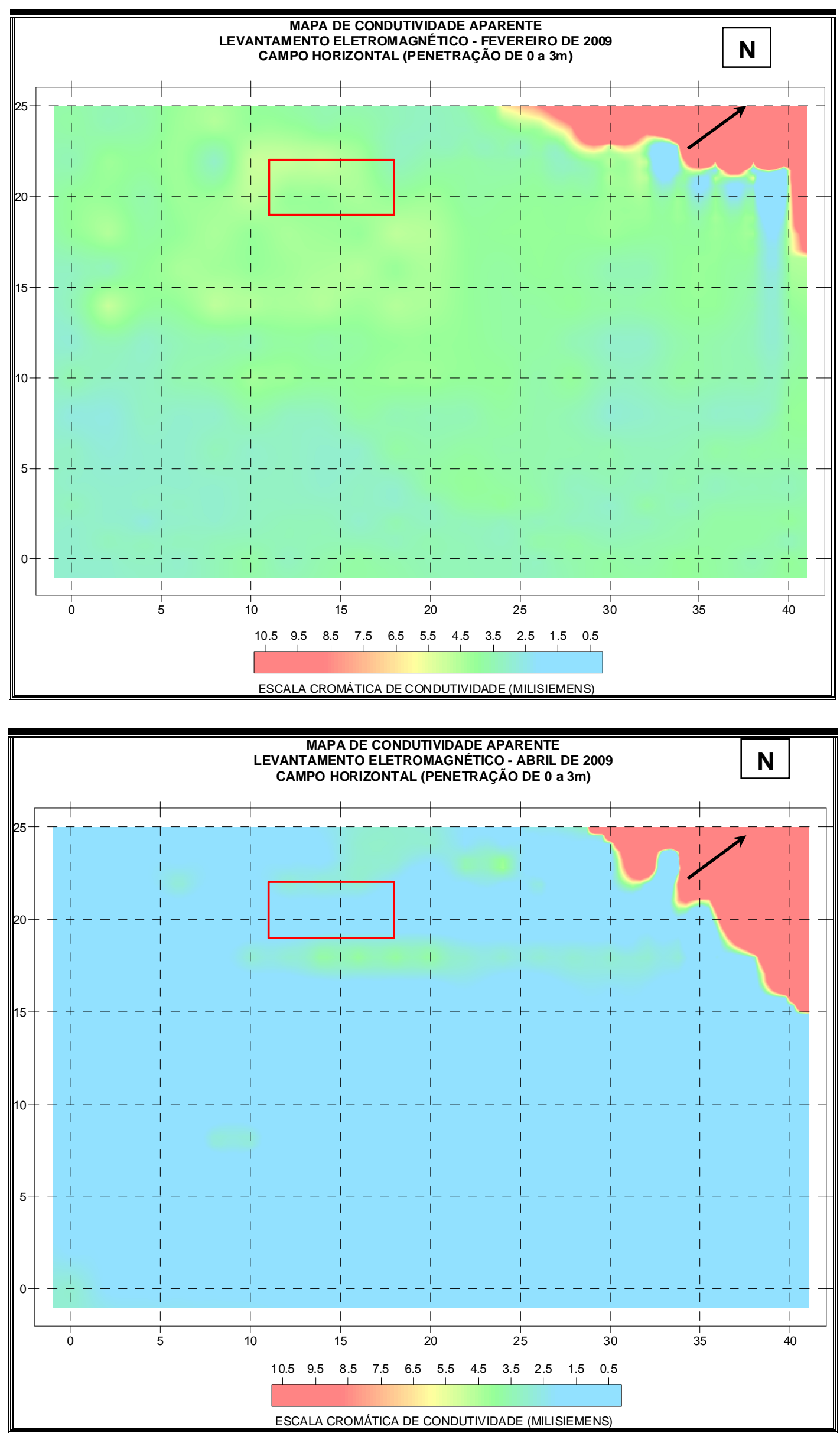
ANEXO III

MAPAS DE GEORADAR 


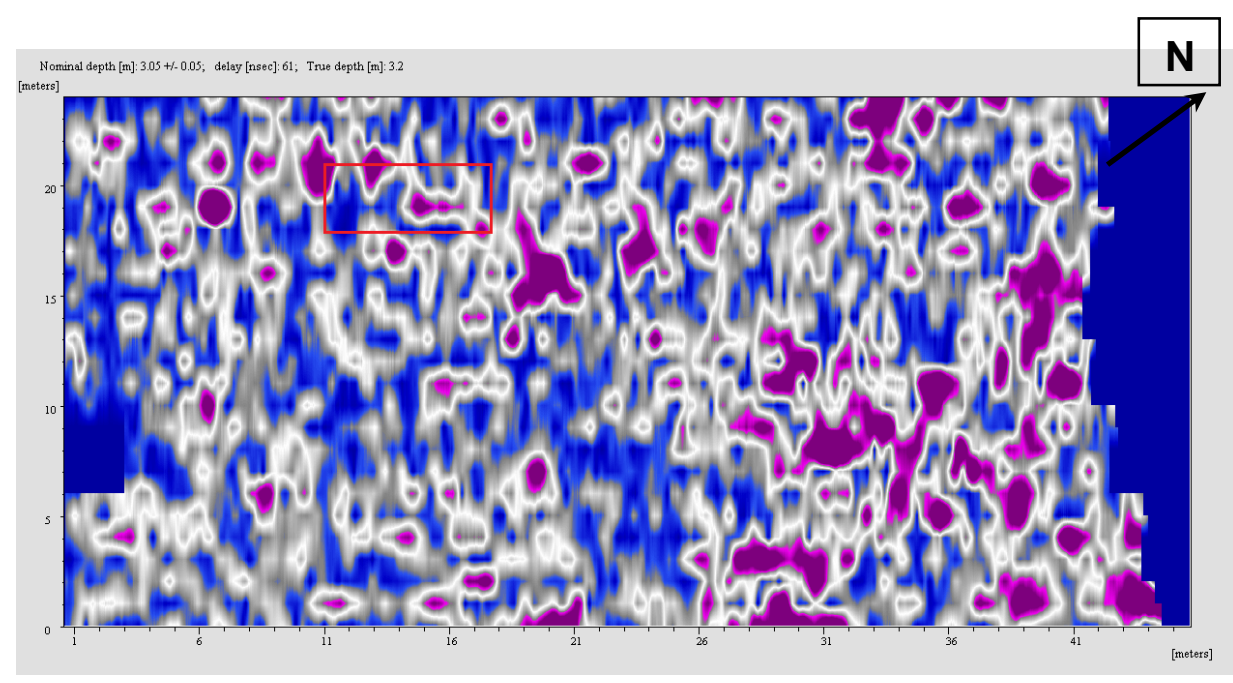

Agosto de 2008

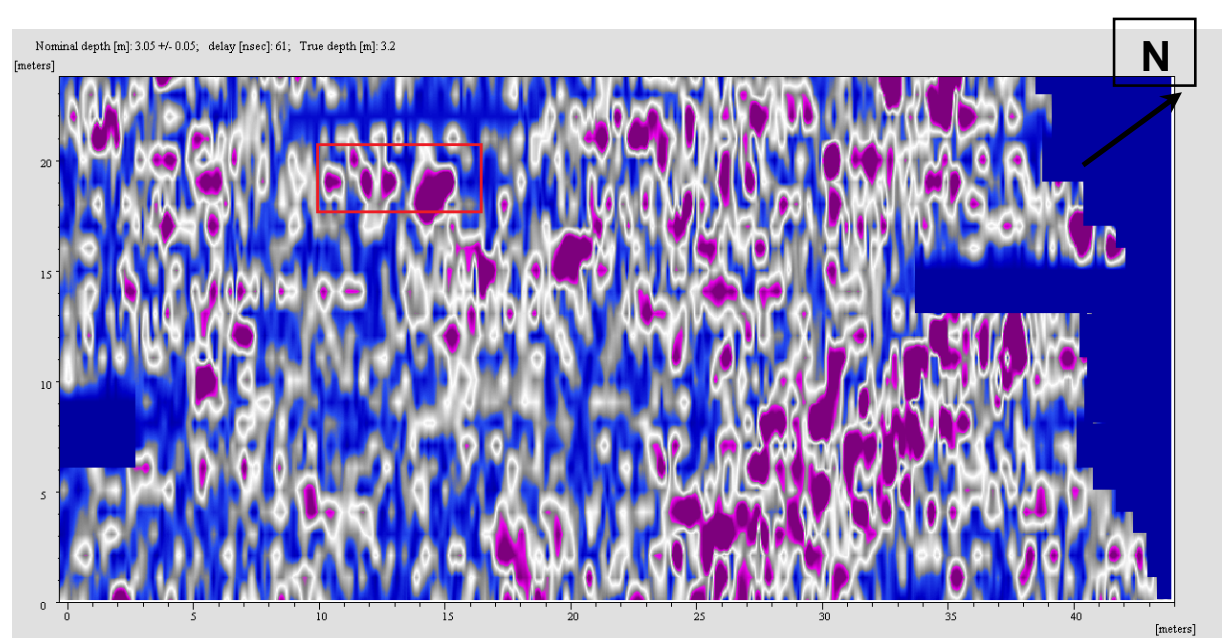

Fevereiro de 2009

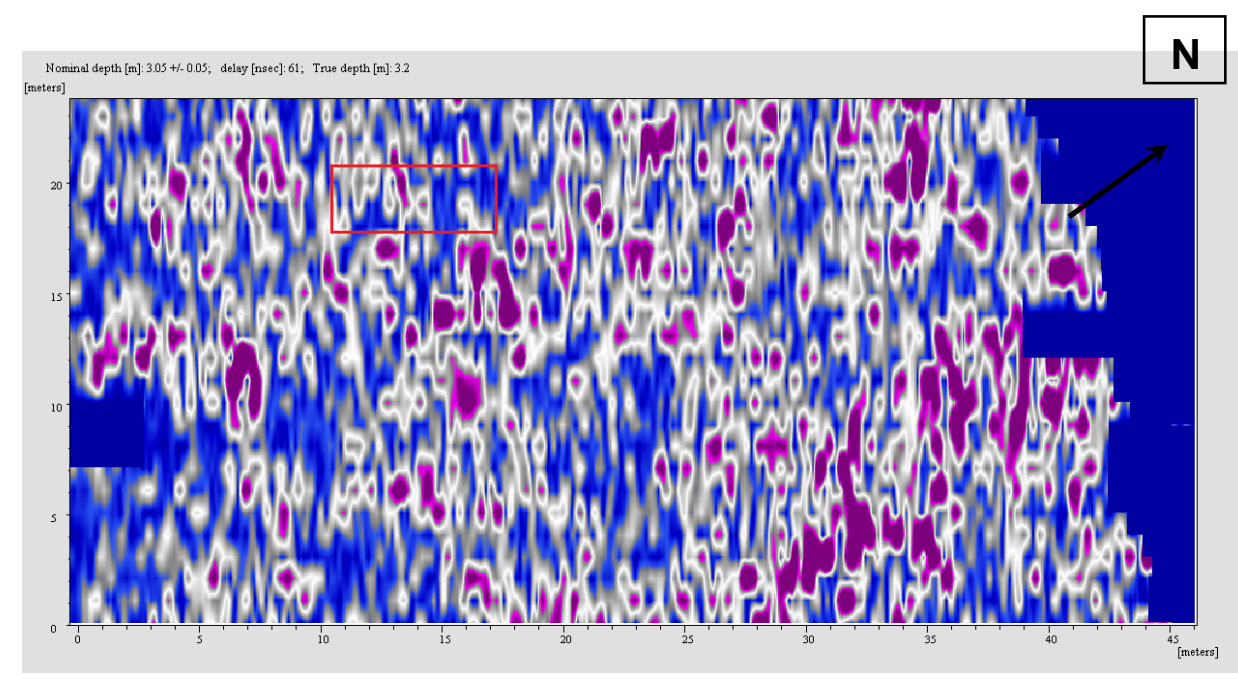

Outubro de 2008

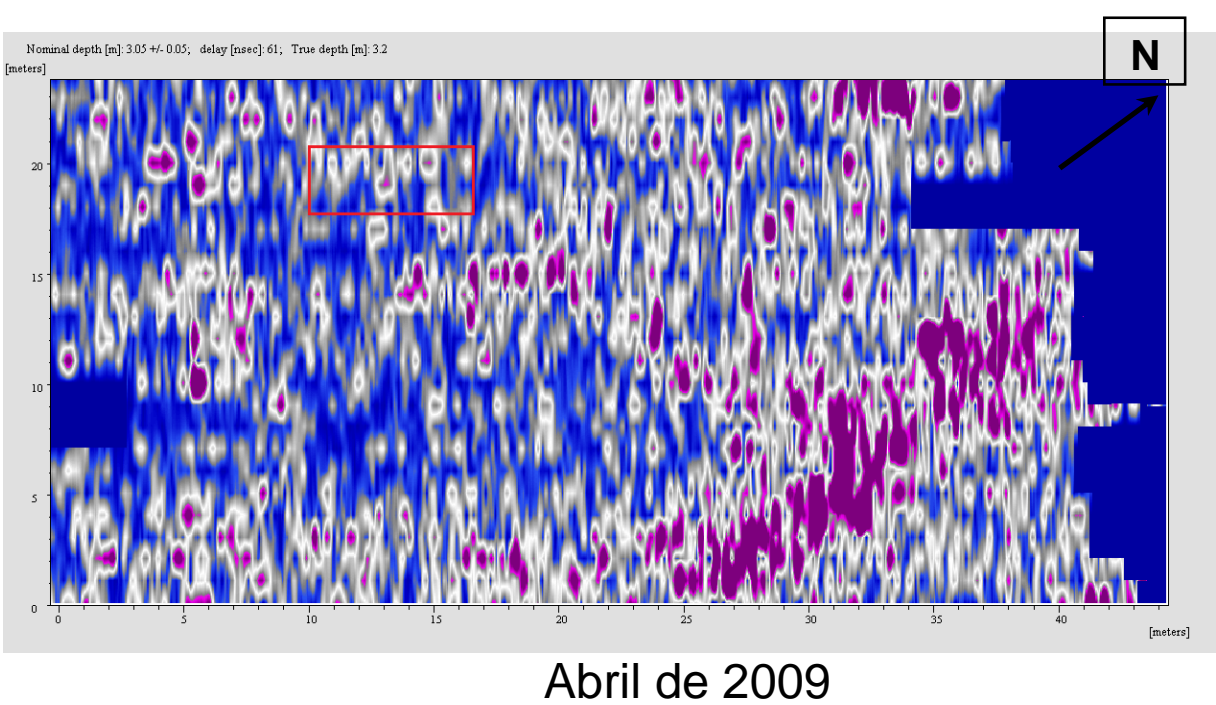

Mapas à profundidade de $3.2 \mathrm{~m}$ 


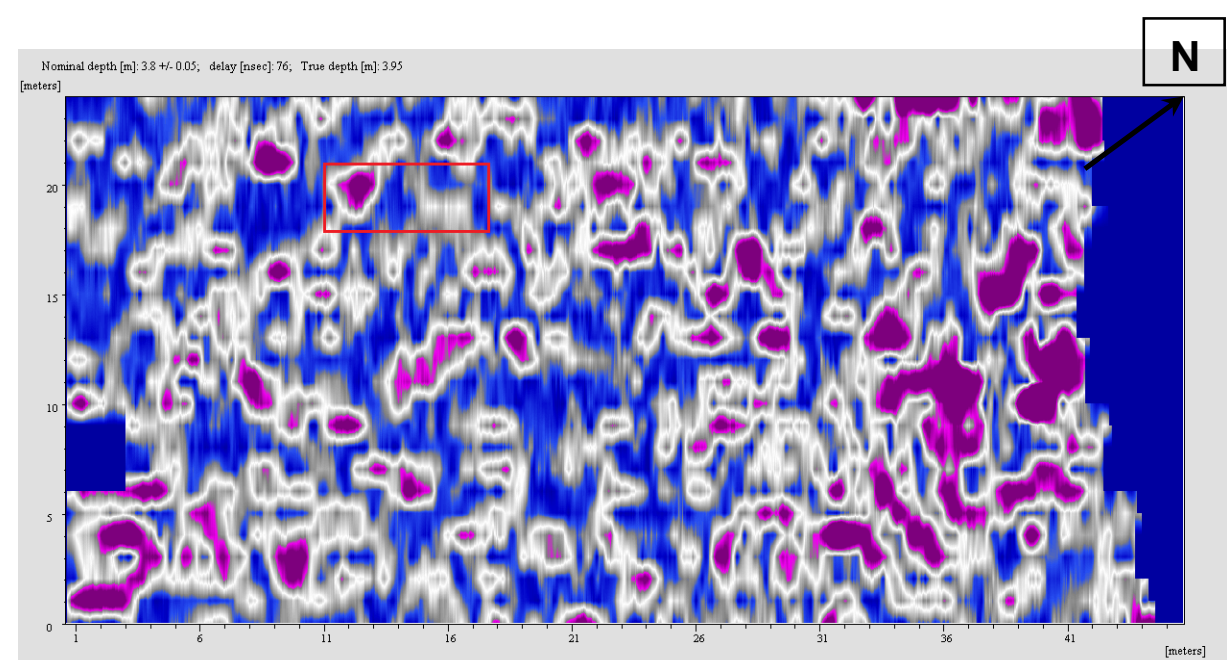

Agosto de 2008

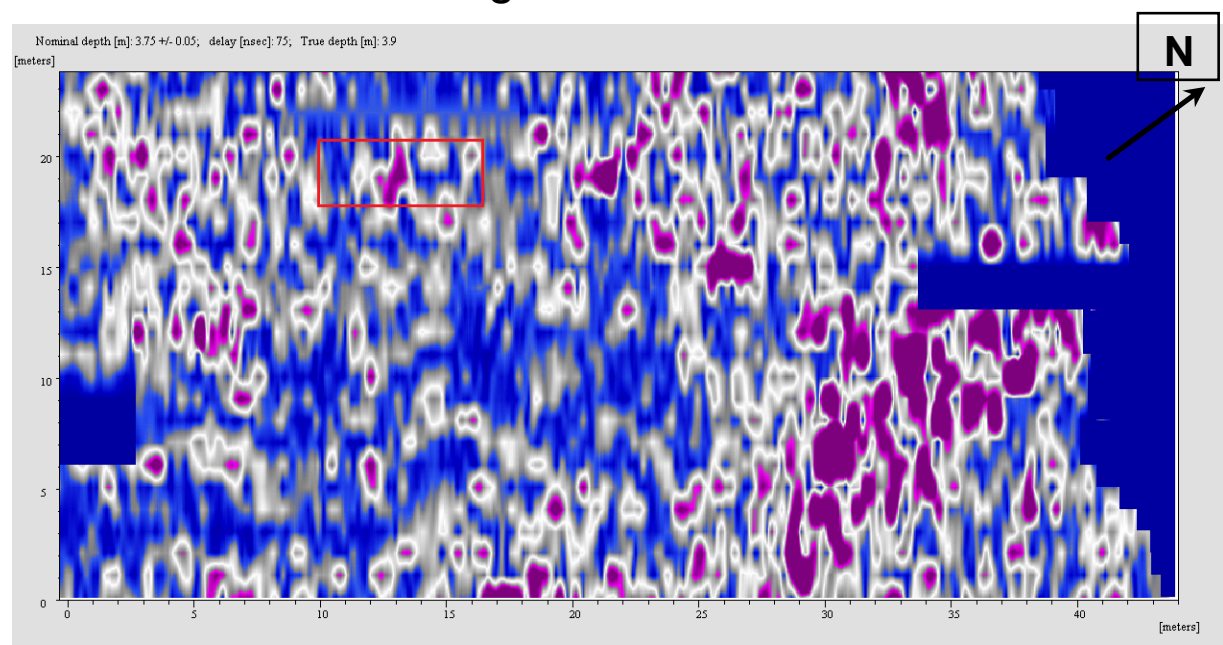

Fevereiro de 2009

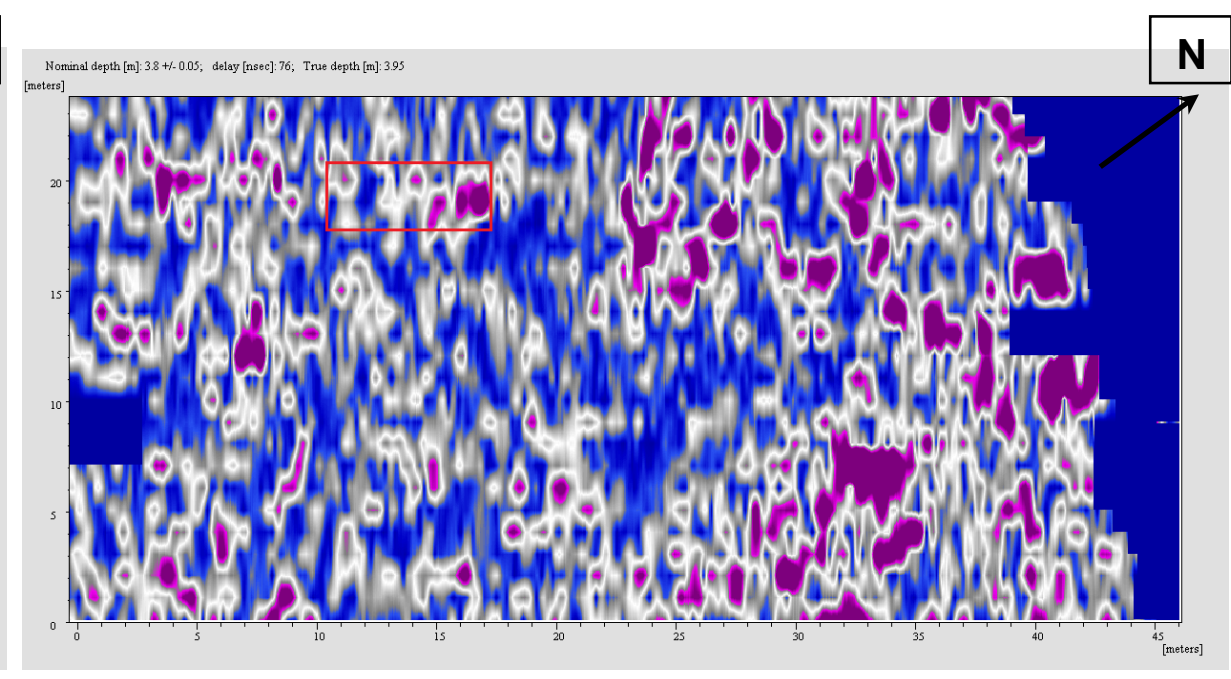

Outubro de 2008

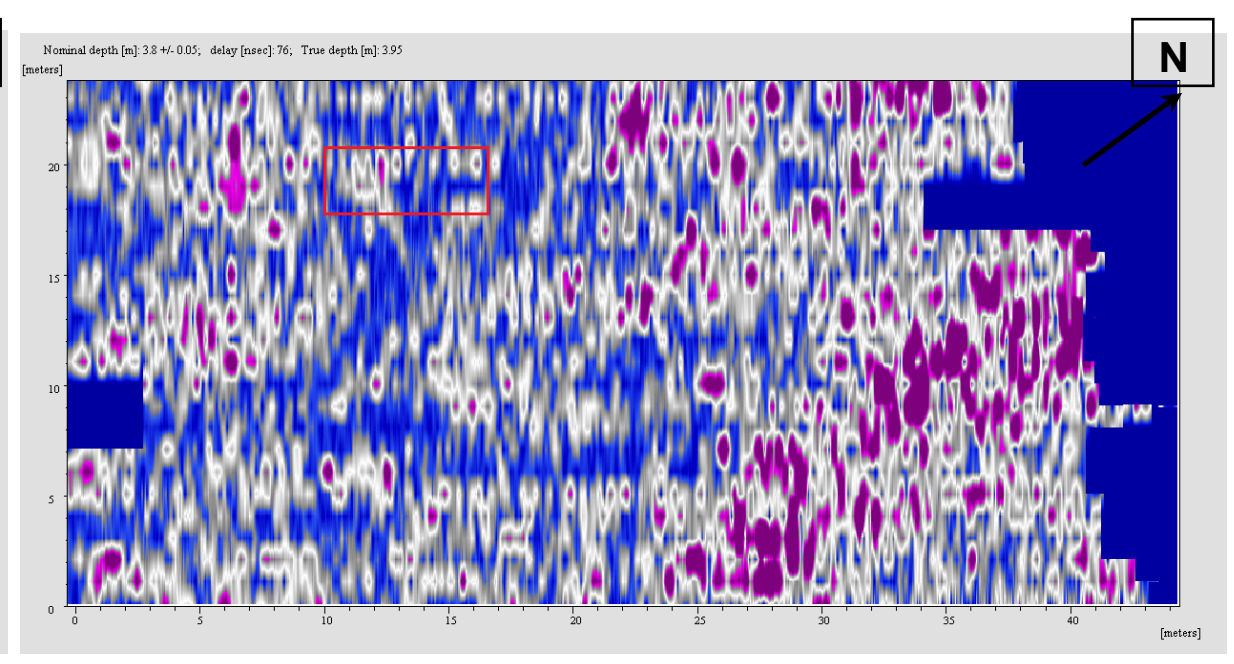

Abril de 2009

Mapas à profundidade de $3.95 \mathrm{~m}$ 


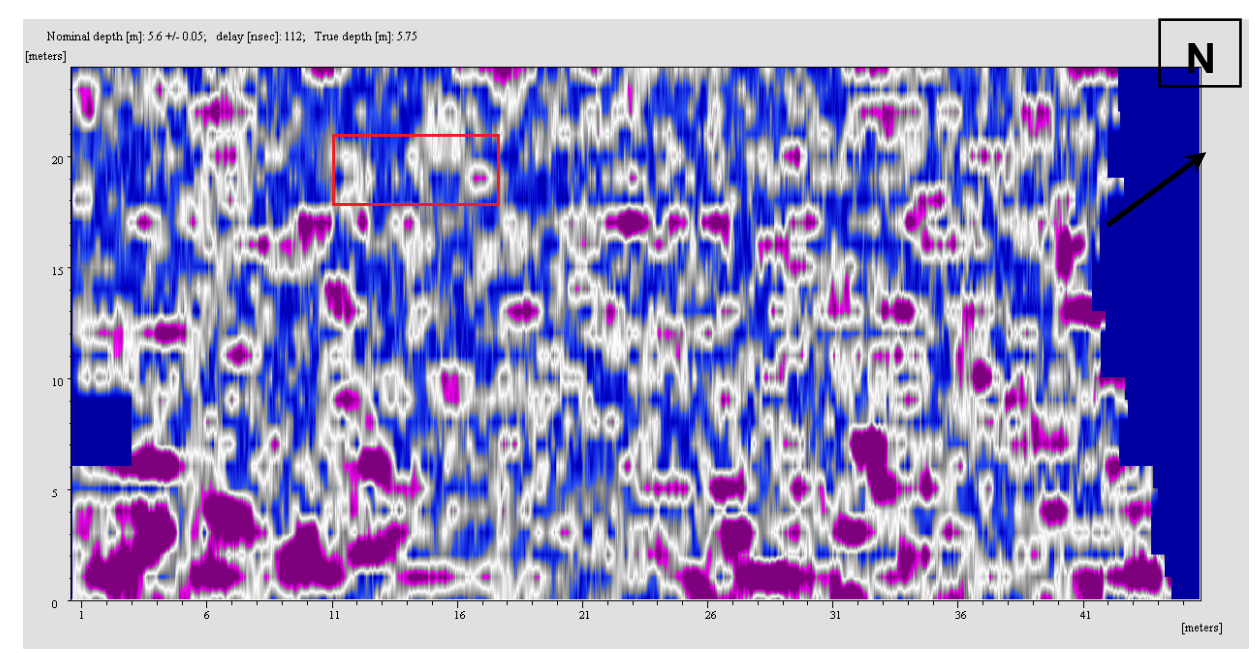

Agosto de 2008

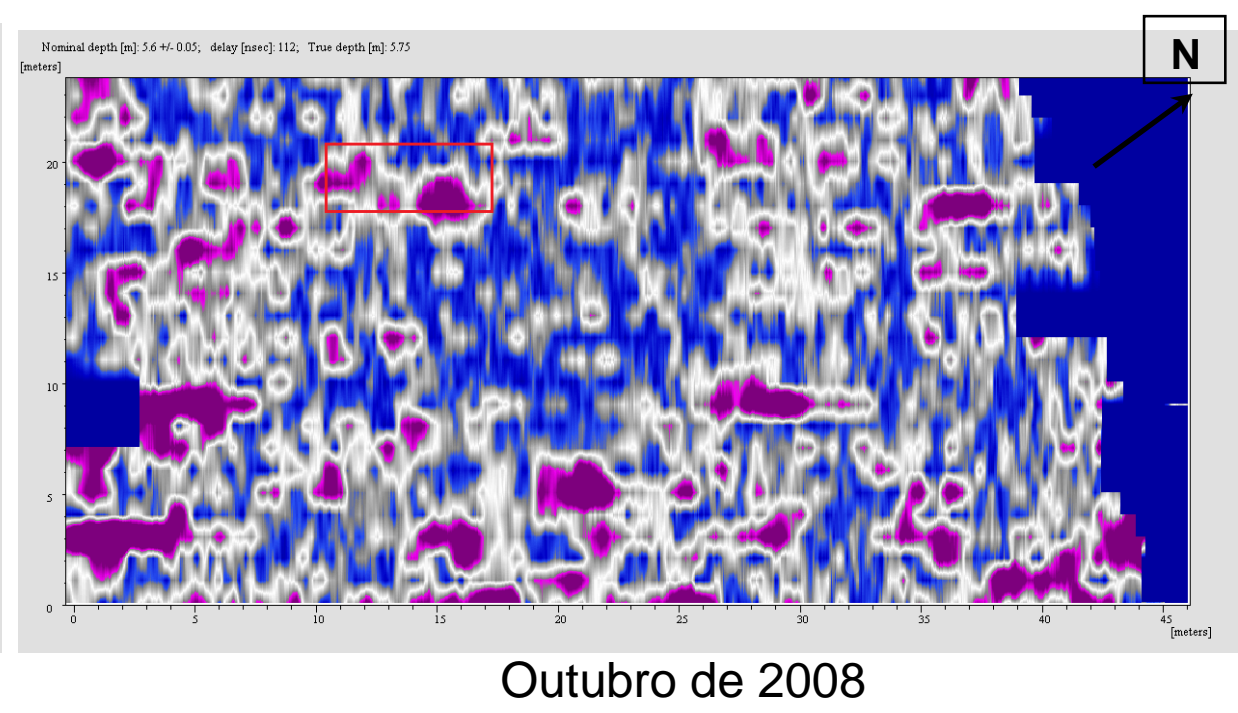

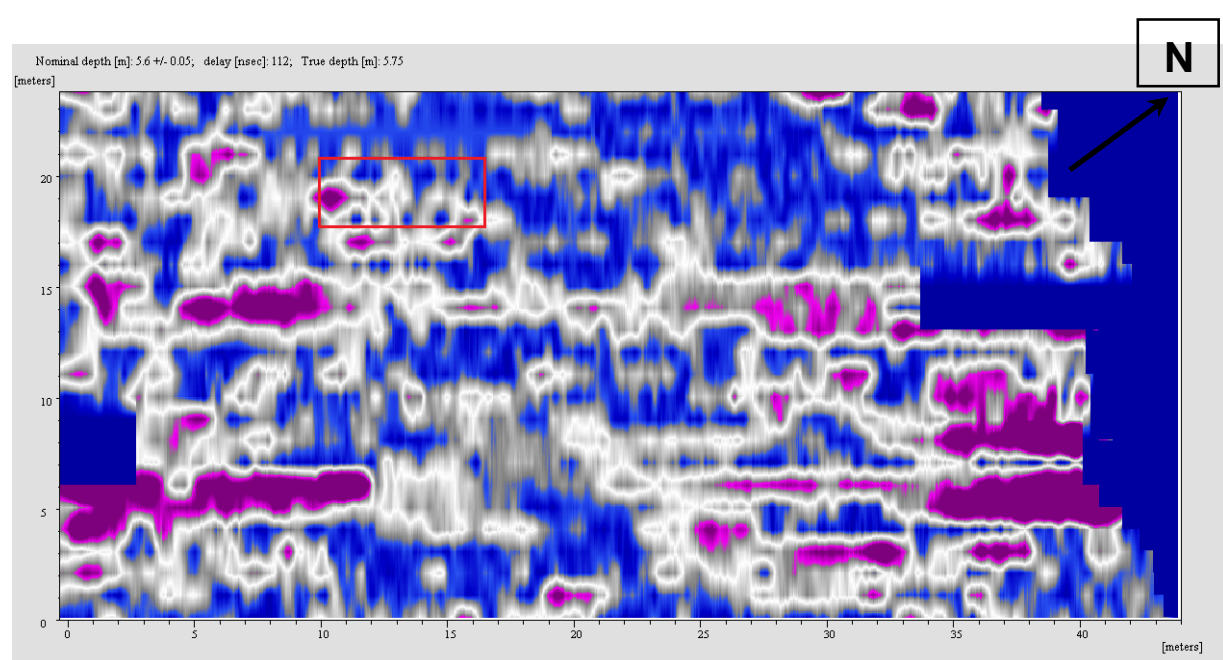

Fevereiro de 2009

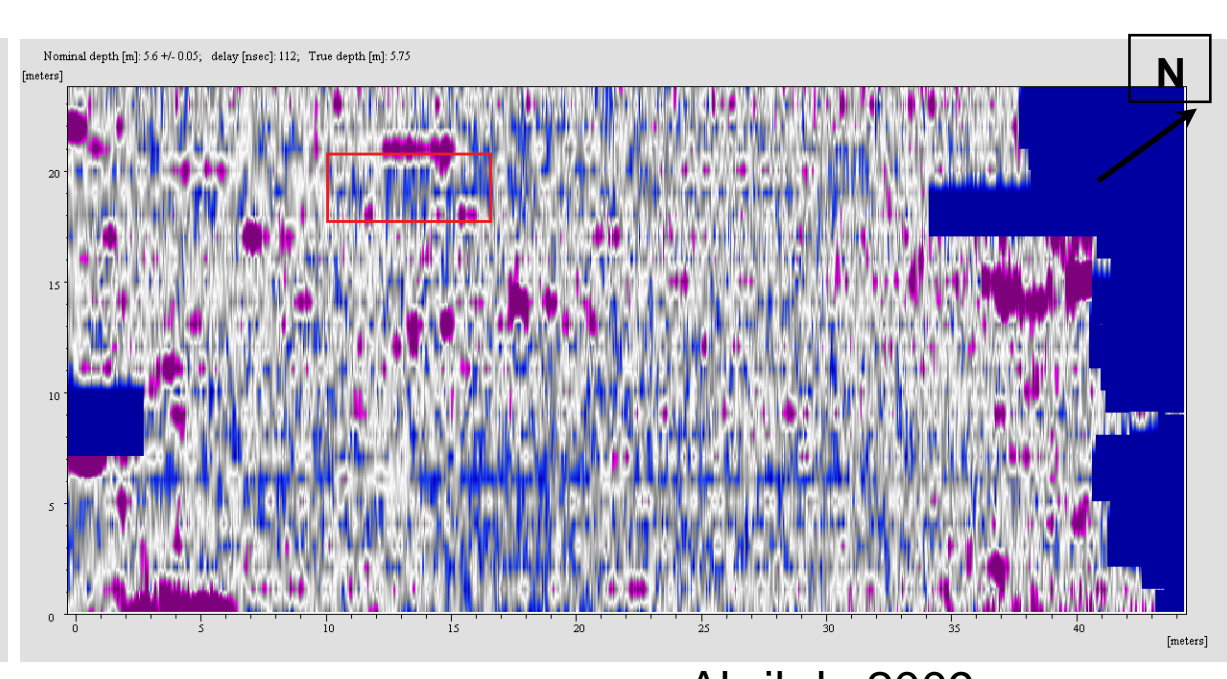

Abril de 2009

Mapas à profundidade de $5.75 \mathrm{~m}$ 


\section{ANEXO IV}

\section{MAPAS DE CAMINHAMENTO \\ ELÉTRICO}



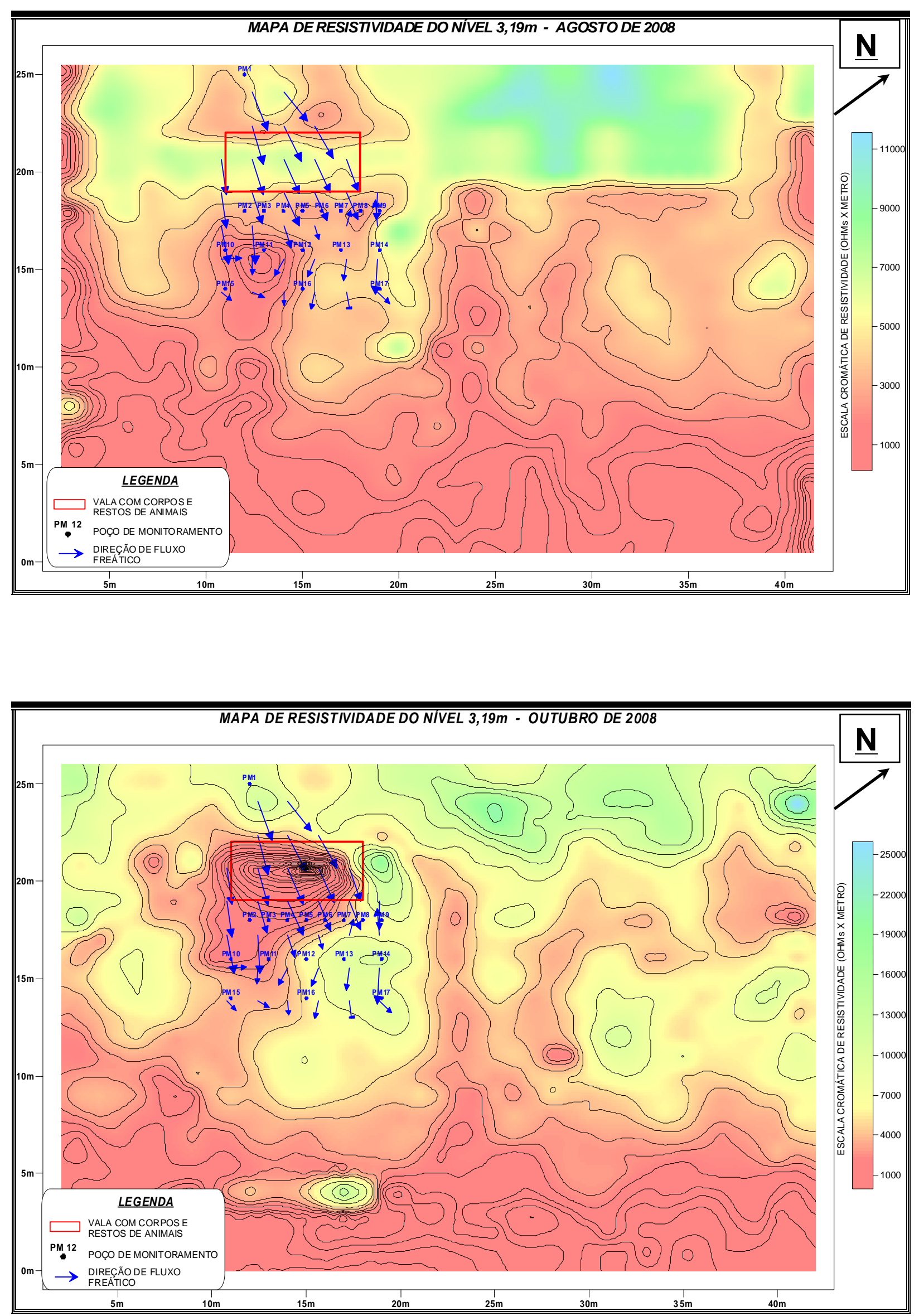

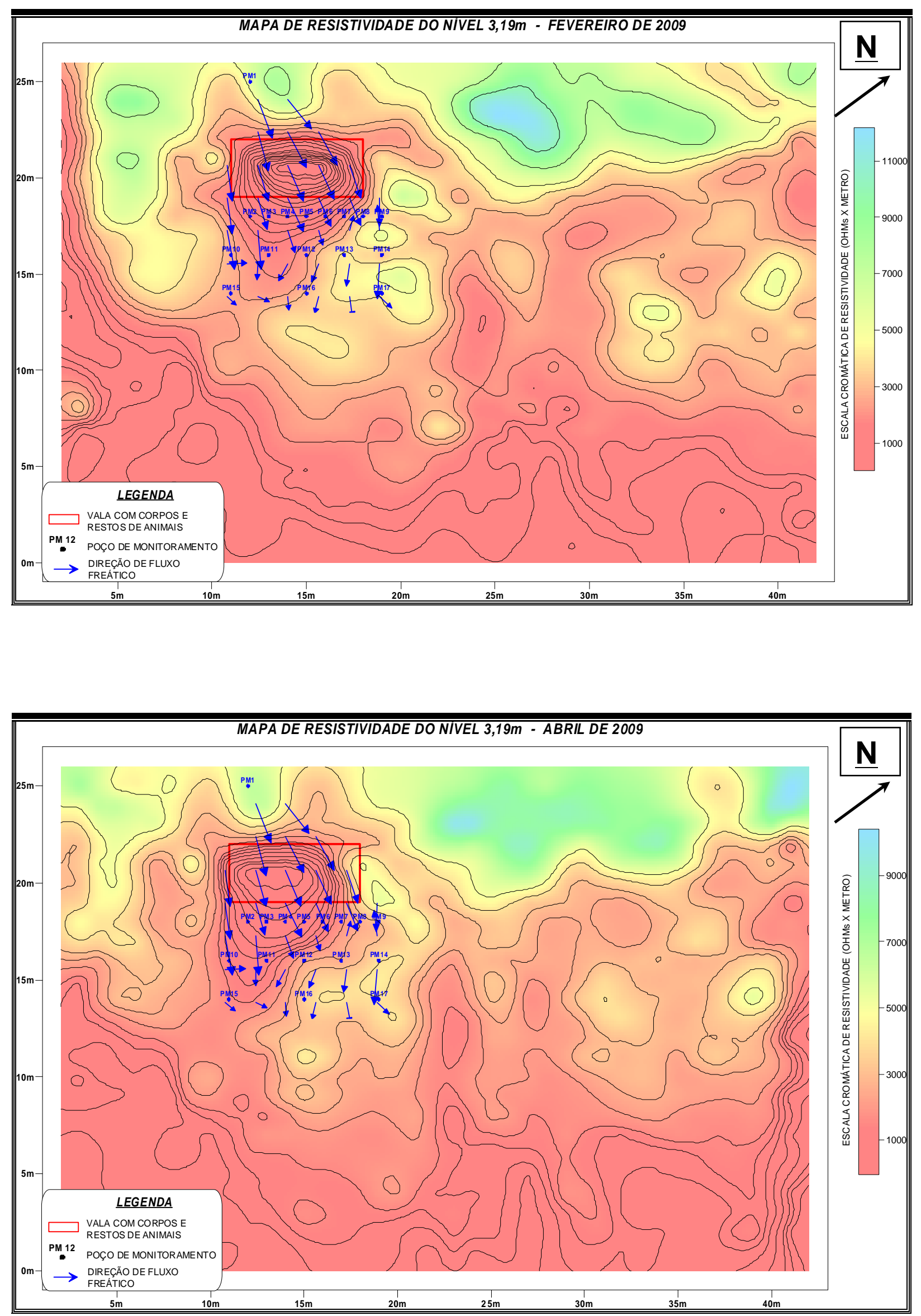

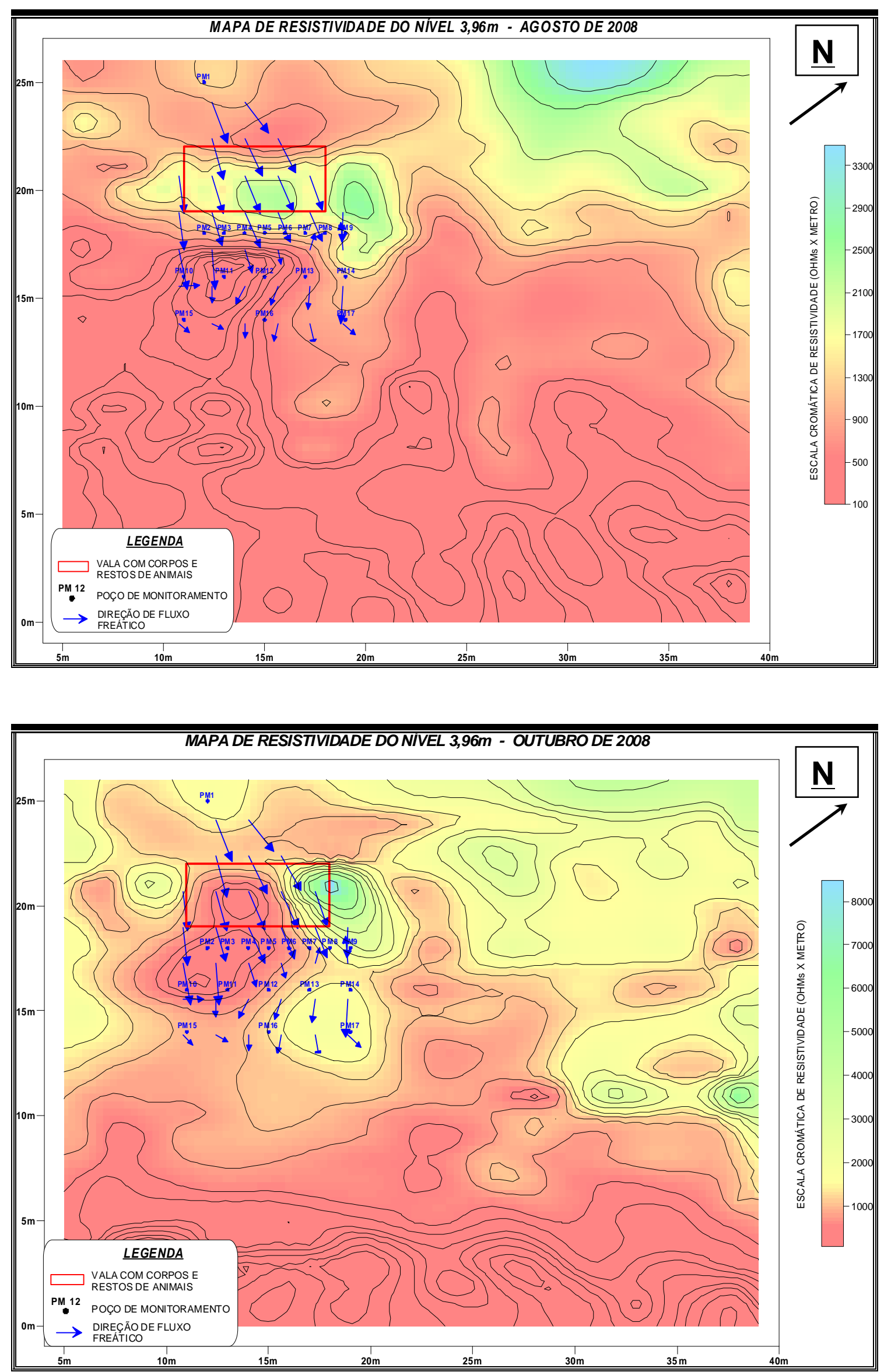

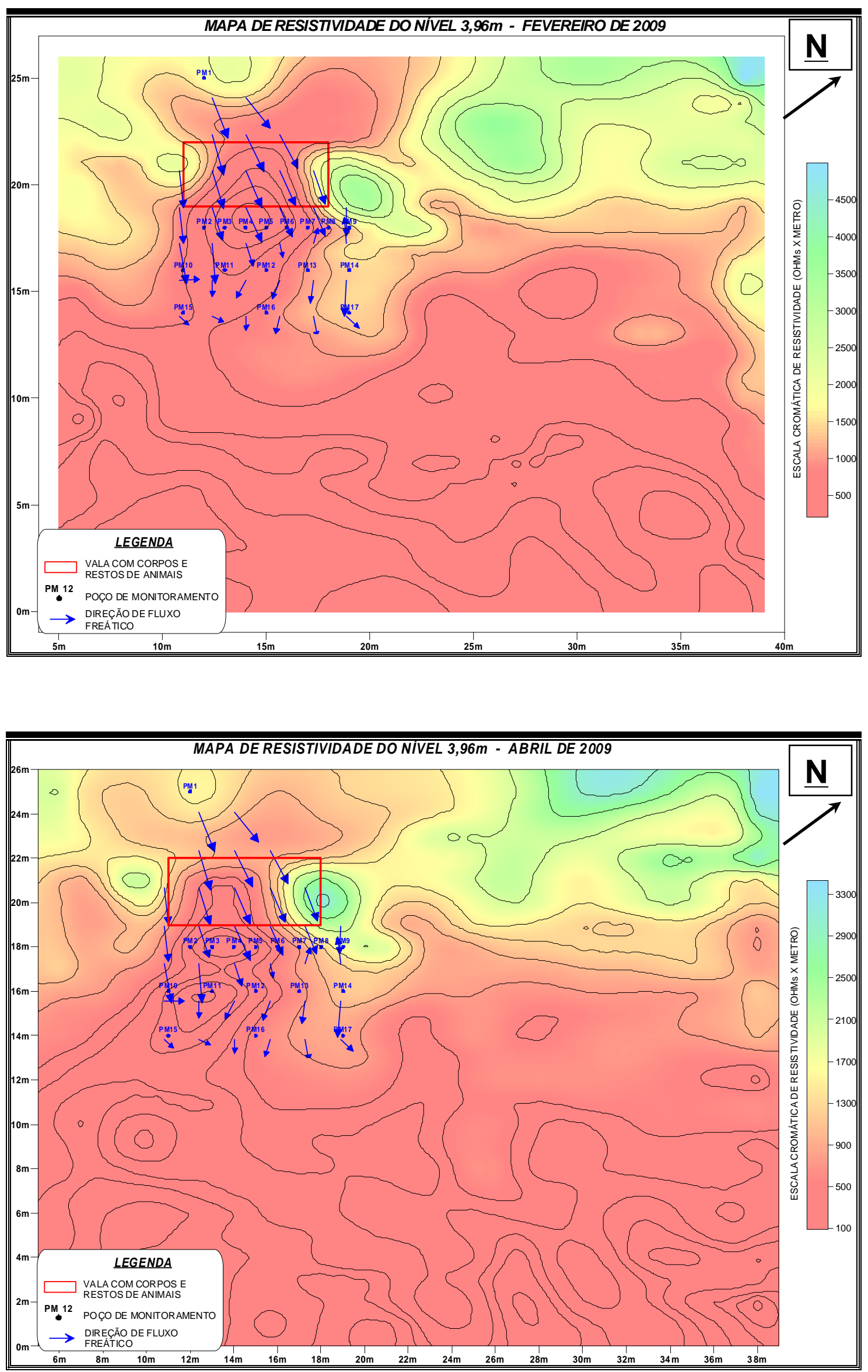

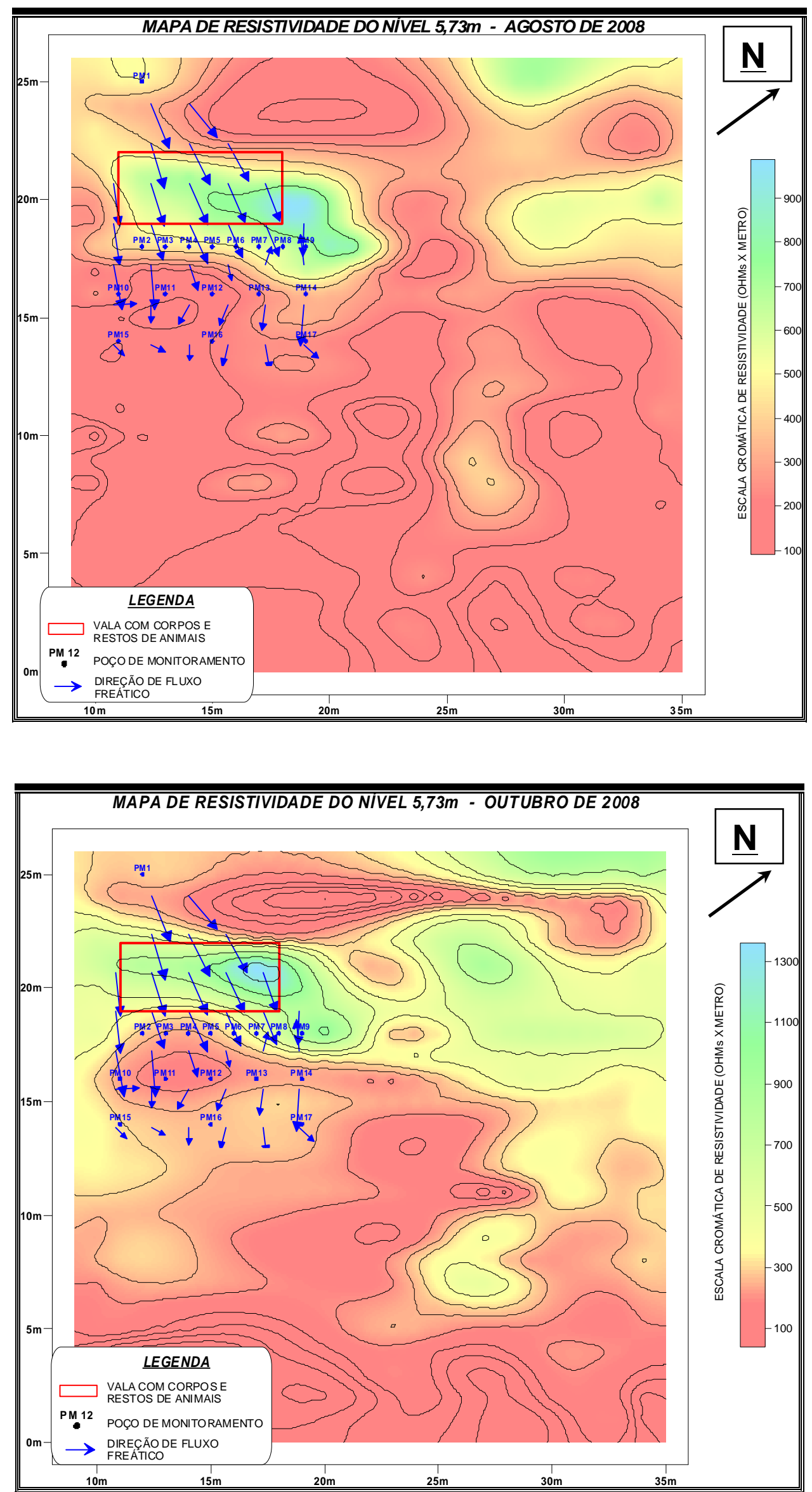

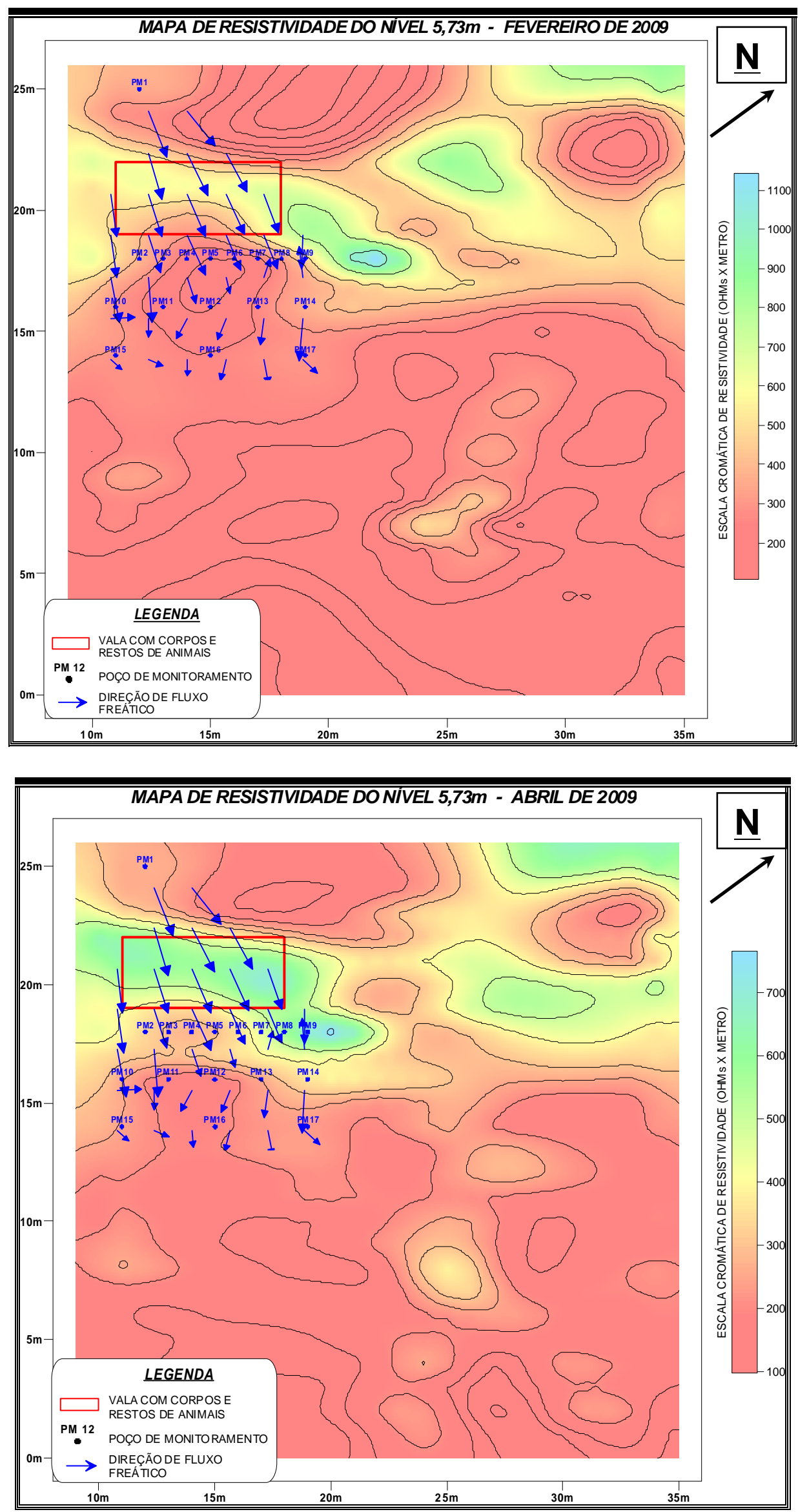